Florida International University

FIU Digital Commons

FIU Electronic Theses and Dissertations

University Graduate School

6-25-2019

\title{
Effects of Phosphorus on Benthic Diatom Assemblage Network Structure
}

Eric M. Massa

Florida International University, emass016@fiu.edu

Follow this and additional works at: https://digitalcommons.fiu.edu/etd

Part of the Other Ecology and Evolutionary Biology Commons

\section{Recommended Citation}

Massa, Eric M., "Effects of Phosphorus on Benthic Diatom Assemblage Network Structure" (2019). FIU Electronic Theses and Dissertations. 4235.

https://digitalcommons.fiu.edu/etd/4235

This work is brought to you for free and open access by the University Graduate School at FIU Digital Commons. It has been accepted for inclusion in FIU Electronic Theses and Dissertations by an authorized administrator of FIU Digital Commons. For more information, please contact dcc@fiu.edu. 


\title{
FLORIDA INTERNATIONAL UNIVERSITY
}

Miami, Florida

\section{EFFECTS OF PHOSPHORUS ON BENTHIC DIATOM ASSEMBLAGE NETWORK}

STRUCTURE

\author{
A thesis submitted in partial fulfillment of \\ the requirements for the degree of \\ MASTER OF SCIENCE
}

in

BIOLOGY

by

Eric M. Massa 
To: Dean Michael R. Heithaus

College of Arts, Sciences, and Education

This thesis, written by Eric M. Massa, and entitled Effects of Phosphorus on Benthic Diatom Assemblage Network Structure, having been approved in respect to style and intellectual content, is referred to you for judgment.

We have read this thesis and recommend that it be approved

Todd Crowl

Jennifer Rehage

Evelyn Gaiser, Major Professor

Date of Defense: June 25, 2019

The thesis of Eric M. Massa is approved.

$\begin{array}{r}\text { Dean Michael R. Heithaus } \\ \text { College of Arts, Sciences and Education } \\ \hline \begin{array}{r}\text { Andrés G. Gil } \\ \text { Vice President for Research and Economic Development } \\ \text { and Dean of the University Graduate school }\end{array}\end{array}$

Florida International University, 2019 
C C Copyright 2019 by Eric M. Massa

All rights reserved. 
DEDICATION

For family. 


\section{ACKNOWLEDGMENTS}

I'd like to acknowledge my major advisor, Dr. Evelyn Gaiser, for many suggestions, pieces of advice, and opportunities over the last two and a half years. My committee members Dr. Todd Crowl and Dr. Jennifer Rehage for additional advice and suggestions. Dr. Marco Scotti of GEOMAR Helmholtz Centre for Ocean Research in Kiel, Germany for instruction in the network analysis tools used in this project at a course hosted by PR

Statistics in Glasgow, UK. Franco Tobias, Rafael Travieso, and many others in the Periphyton lab for collecting and analyzing samples over the years which were used in this project. Finally, the sources of funding for this project. Data were collected with funding from the Comprehensive Everglades Restoration Plan Monitoring and Assessment Program - U.S. Army Corps of Engineers and the South Florida Water Management District, developed in collaboration with Florida Coastal Everglades Long Term Ecological Research program under Cooperative Agreements \#DEB-1237517, \#DBI- 0620409, and \#DEB-9910514. My own work was partially funded through the 2018 FIU ForEverglades Scholarship from the Everglades Foundation. 


\title{
ABSTRACT OF THE THESIS \\ EFFECTS OF PHOSPHORUS ON BENTHIC DIATOM ASSEMBLAGE NETWORK STRUCTURE
}

By

\author{
Eric M. Massa
}

Florida International University, 2019

Miami, Florida

Professor Evelyn Gaiser, Major Professor

Ecological network analysis helps identify how relationships among species differ over time and across sets of species. Microbial assemblages are ideal for evaluating changes in species interactions due to environmental changes because they are speciose and respond at multiple scales. To determine how phosphorus limitation influences diatom network structure, I analyzed relationships among 257 species of diatoms from benthic microbial (periphyton) mats from 10 years of annual samples from 136 sites. Expected evidence of changes in network structure in response to periphyton TP were not found, likely due to species replacement with increased TP. Analysis of species connection distributions and the effects of species removal on connections found frequency increases with TP for 23 species with significant roles in network structure, variable frequency for 15 species, and 13 species consistently decreased in frequency. This study brings a new methodology of study to the field of ecosystem restoration studies. 
TABLE OF CONTENTS

CHAPTER
I. Introduction
II. Methods




\section{LIST OF TABLES}

TABLE

PAGE

1. Basins of the Everglades sampled in CERP MAP 2007-2016

7

2. Network measures tested and expected behaviors of those measures if the null

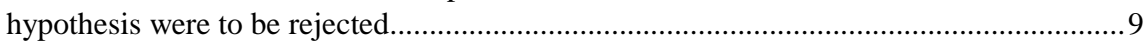

3. Table describing the distribution of data utilized in analyses.....................................12

4. Species with significant differences in mean first-order ego size between otherwise identical networks with and without those species....................................................... 19

5. Summary of periphyton TP changepoints in the Everglades from previous works (Gaiser, 2009; Gaiser et al., 2006), as well as the changepoints found in this study.........24 
1. A map of all CERP MAP sites visited as part of CERP and the periphyton ash-free dry

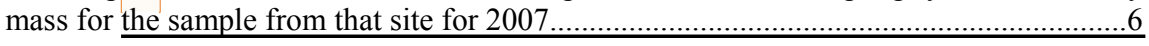

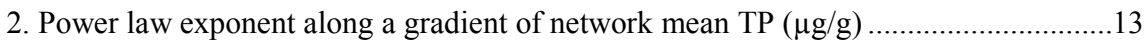

3. A network generated utilizing data from 2007 with a mean TP of $93.7 \mu \mathrm{g} \mathrm{TP} / \mathrm{g}$ periphyton dry mass

4. A network generated using data from 2007 with a mean TP of $273.6 \mu \mathrm{g} \mathrm{TP} / \mathrm{g}$ periphyton dry mass.

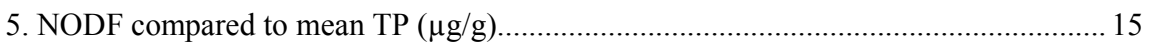

6. Mean first-order ego size compared to mean TP $(\mu \mathrm{g} / \mathrm{g})$..................................................15

7. Change in mean ego size for networks that contain the species Achnanthidium minutissimum var. gracillima versus the same networks with the node representing $A$.

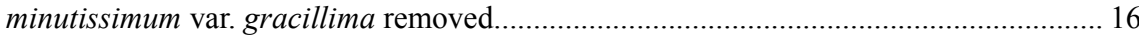

8. Frequency of diatom taxon Achnanthidium minutissimum var. gracillima in each network for years 2007-2016.....

9. Frequency of diatom taxon Brachysira microcephala in each network along a mean $\mathrm{TP}(\mu \mathrm{g} / \mathrm{g})$ gradient for years $2007-2016$.

10. Frequency of diatom taxon Caponea caribbea in networks along a mean TP $(\mu \mathrm{g} / \mathrm{g})$

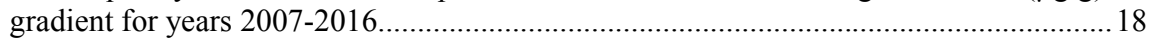

11. Frequency of diatom taxon Encyonopsis subminuta in each network along a mean TP $(\mu \mathrm{g} / \mathrm{g})$ gradient for years $2007-2016 .$. 


\section{LIST OF ABBREVIATIONS AND ACRONYMS}

Analysis of Variance




\section{Introduction}

All species form assemblages of variable composition and complexity in nature, and collections of assemblages representing multiple ecological roles can form communities with resource limitation often determining the presence and strength of specific interdependencies between species (e.g., mutualisms) (Gotelli \& McCabe, 2002; Muller et al., 2014). The three major challenges in community ecology relating to nontrophic interactions are why do species co-occur, how to determine the influence of any one species on other species in the community, and how environmental drivers alter patterns of co-occurrence (Gotelli \& McCabe, 2002; Ives \& Carpenter, 2007; Pellissier et al., 2018). Species co-occurrence and multiple types of interaction are studied in many systems, from how predator-prey relationships change in food webs to the interactions between microbial taxa in gut biomes (e.g., Allesina \& Pascual, 2008; Tsai et al., 2015).

There also exists a large body of work on the effects of diversity in one side of directional interactions on the other such as how pollinator diversity can alter plant communities (e.g., CaraDonna et al., 2017; Pocock et al., 2011). How the degree of species codependences and how the form those co-dependencies take change along gradients of resource availability to influence biodiversity and ecosystem function remains a significant challenge in ecology (e.g., Berry \& Widder, 2014; Mills et al., 1993; Ovaskainen et al., 2017; Wiegand et al., 2007).

Microbial communities are ideal models to study how non-trophic interactions change to alter diversity patterns along resource gradients, especially interactions which are complex and mutualistic. First, unexpectedly specious microbial communities can exist in seemingly homogenous and resource-limited environments, partially driven by 
species inter-dependencies that enhance resource use efficiency (Cirri \& Pohnert, 2019; Harpole et al., 2011; Hutchinson, 1961; Nemergut et al., 2013). Second, they tend to have meaningful patterns of species dominance and rarity, including foundation, or "core", species (those that have an outsized impact on local conditions relative to their abundance) whose abundance changes reliably along environmental gradients (Marazzi \& Gaiser, 2018; Schöb et al., 2012). Changes in foundation species (especially extinctions) are known to drive diversity patterns and may have cascading effects on other parts of the community (Ellison et al., 2005; Hooper et al., 2012). Third, microbial communities and their emergent properties are influenced by resource limitation, as species interdependencies develop at the physiological level which enable and encourage coexistence (Cotner \& Biddanda, 2002). This results in species which co-occur being at least partially reliant on the products of other species for resources.

Microbial interactions that produce emergent properties are particularly are evident in the formation of complex biofilms or mats (La Hée \& Gaiser, 2012; Lee et al., 2013; Reid et al., 2000; Scinto \& Reddy, 2003). For example, in limestone-rich regions of the world, distinctive microbial communities containing species with restricted biogeographic distributions form very thick, calcareous mats similar to marine stromatolites, (La Hée \& Gaiser, 2012; Lee et al., 2013; Reid et al., 2000; Scinto \& Reddy, 2003). Phosphorus availability structures these ecosystems, including community organization (e.g., Gaiser et al., 2006; Mazzei \& Gaiser, 2018; Noe et al., 2001; Sokol et al., 2014). When exposed to above-ambient levels of phosphorus, endemic species disappear, leading to structural collapse of the calcareous mat structure through suspected changes in species co-dependencies (Evelyn E. Gaiser et al., 2006). In oligotrophic 
ecosystems exposed to nutrient subsidies, these changes in microbial community resource-sharing dependencies have cascading effects throughout ecosystem resulting from a loss of rare species and the functional roles that those species play (Evelyn E. Gaiser et al., 2005). These functions include regulating water column nutrients and gasses, the production of enzymes and other metabolites, and producing biomass that is consumed by meiofauna and other consumers (Cirri \& Pohnert, 2019; Ewe et al., 2006; Sabater et al., 2003). Due to their responsiveness to environmental conditions, their importance in ecosystems, and the ease with which they can be sampled, microbial communities have been used as ecological risk indicators in these ecosystems and around the world multiple states for (Stevenson, 1998; Stevenson et al., 2010).

The Everglades is an iconic example of a karst wetland and is host to extensive calcareous microbial mats (periphyton) that are responsible for over half of net primary productivity much in the ecosystem (Ewe et al., 2006; E. Gaiser, 2009). Periphyton is known for its emergent properties including the development of calcareous threedimensional structure and is known to dissolve when exposed to excess phosphorus (Chick et al., 2008; Gaiser et al., 2006) The total phosphorus (TP) content of periphyton is used to detect phosphorus enrichment in the Everglades as $\mathrm{P}$ is rapidly taken up by the environment or adsorbed to the limestone bedrock of the area to the extent that levels of dissolved $\mathrm{P}$ in the water are usually below the detection thresholds of most analytical techniques, and periphyton is easily sampled at field sites for later laboratory analysis (E.E. Gaiser et al., 2004). Due to the wide variety of species which can live in periphyton and the high variability of species found in samples, these communities present an excellent opportunity for studying the interactions between species across environmental 
gradients. Once the effect of species in communities on other species are understood, the effects of changing conditions on emergent properties can be better understood through further analyses. These properties enable the prediction of diversity from understanding the roles of certain species on others.

Network approaches to ecological research have been useful for understanding how relationships between species differ over environmental gradients? (Ings et al., 2009; Olesen et al., 2008; Thompson, 2006). Network analysis can be utilized to predict community structure responses to changes of one or more environmental variables (Proulx et al., 2005; Spieles \& Mitsch, 2000). One method of studying community dynamics is ecological network analysis (ENA), which has been used in studying the maintenance of community structure in microbial assemblages in medical and ecological studies (e.g., Fernandez et al., 2015; Koenig et al., 2011; Kurtz et al., 2015; Layeghifard et al., 2017). By applying ENA over different scales or gradients of interest, community dynamics can be revealed (Astegiano et al., 2017). While trophic ENA is widely known within the field of ecology (Layman et al., 2015), a rich library of work on non-trophic ENA also exists (Guimarães et al., 2017; Olesen et al., 2006). Much of the work on nontrophic ENA is related to plant-pollinator interactions (Alarcon, 2004; Olesen et al., 2008; Pocock et al., 2011) or the epidemiology of agricultural diseases (Jeger, 2000; Jeger et al., 2004; Margosian et al., 2009; Pautasso \& Jeger, 2014). While some work has been done using ENA in researching aquatic microbial communities, there has been less work done in this area than in terrestrial ecology or medicine (e.g., Carey et al., 2017; Lima-Mendez et al., 2015; Morales-Castilla et al., 2015; Steele et al., 2011). 
Three ideas will be tested utilizing ENA to study how relationships between species change along environmental gradients. First, I expect that the algal assemblages present in calcareous periphyton will demonstrate a loss of network structure with increased TP. Under natural highly oligotrophic conditions, I expect that ENA will identify a pattern in connection between species which will be indicative of communities with oligotrophic communities, and that pattern deteriorating as conditions become more eutrophic. More specifically, that the probability distribution of species degree - the number of connections between one species and others - will follow a power law distribution (Equation 1) above some minimum threshold of species degree, $x_{\min }$, and that as TP increases, species co-occurrence will become more random, the absolute value of the exponent should decrease, representing a "flattening" of the degree distribution. Power law distributions are commonly found in cases where the frequency of an event (such as species presence) is related to its magnitude (Bascompte \& Jordano, 2014).

Equation 1: Power law probability distribution that a species with degree $\mathrm{k}$ will be found is proportional to $\mathrm{k}$ raised to the exponent $-\gamma$.

$$
\mathrm{P}(\mathrm{k}) \propto \mathrm{k}^{-\gamma}
$$

Second, I expect to find a subset of species in the dataset which have an outsized influence on community structure of networks in which those species occur, or that network nestedness, used as a metric of species interdependence across samples, would decrease in response to nutrient enrichment, representing either a decrease in the importance of highly interdependent specialist species, or an increase in the presence of much less interdependent generalist species, or both. 
Third and finally, I expect that those species identified in testing the second hypothesis will decrease in frequency with increasing TP. This means that I expect that there are species that would serve as a hub or important node, without which, networks would experience a change in the structure of the network. This was tested by comparing networks that contained each species with the same network with that species removed.

\section{Methods}

\section{Field Region Description}

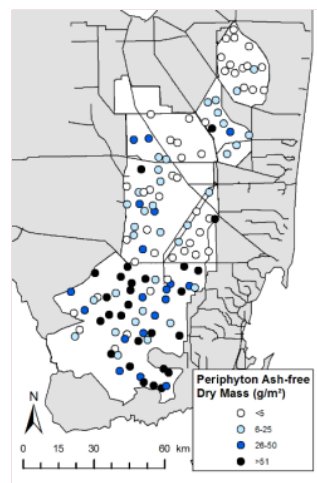

Figure 1. A map of all CERP MAP sites visited as part of CERP and the periphyton ash-free dry mass for the sample from that site for 2007. See table 1 for basin names and abbreviations.

As part of the Comprehensive Everglades Restoration Plan Monitoring and Assessment Plan (CERP MAP), the Everglades were divided into a series of basins, six of which are studied here (table 1). The majority of samples were collected in either SRS $(40 \%)$ or WCA3 $(43 \%)$. 


\begin{tabular}{|l|l|l|}
\hline Basin & Site samples & $\begin{array}{l}\text { Cleaned dataset contains } \\
\text { data from years }\end{array}$ \\
\hline Palmar (PAL) & 15 & $2007,2008,2009,2011$ \\
\hline Pennsuco (PEN) & 1 & 2007 \\
\hline Shark River Slough (SRS) & 399 & $2007-2016$ \\
\hline Taylor Slough (TSL) & 57 & $2007-2016$ \\
\hline $\begin{array}{l}\text { Water Conservation Area 2 } \\
\text { (WCA2) }\end{array}$ & 90 & $2007-2016$ \\
\hline $\begin{array}{l}\text { Water Conservation Area 3 } \\
\text { (WCA3) }\end{array}$ & 445 & $2007-2016$ \\
\hline
\end{tabular}

Table 1. Basins of the Everglades sampled in CERP MAP 2007-2016. Additionally, the number of site samples and the number of years that the basin in question is in the cleaned dataset.

\section{Field Sampling}

From 2007 to 2016, periphyton was collected annually during the wet season in a synoptic sampling program associated with CERP MAP through the Everglades that addresses the effectiveness of hydrologic restoration in restoring oligotrophic conditions of Everglades wetlands. Generalized random-tessellation stratification was used to select sampling sites, which were visited by helicopter (Stevens \& Olsen, 2004). For this program, the Everglades was divided into basins and sampling within each basin was performed by dividing it into $800 \mathrm{~m}$ x $800 \mathrm{~m}$ Principal Sampling Units (PSUs) which were selected randomly for each year (Figure 1). At the sampling site, a $1 \mathrm{~m}^{2}$ quadrat was randomly selected for sampling and periphyton surface cover as a percent of that quadrat, and visible composition are recorded. All periphyton in the quadrat is collected and volume measured with a perforated graduated cylinder. A representative $120-\mathrm{mL}$ subsample of periphyton was collected and returned to the lab for further analysis. 


\section{Lab Analysis Methods}

Periphyton subsamples were weighed before non-algal material (e.g., rocks, macrophytic material, gastropod shells) were removed from each sample before homogenizing in distilled water. Subsamples of the periphyton homogenate were taken for multiple analyses: a 10-mL subsample was oxidized for diatom analysis, a 40-mL sample was used to measure periphyton dry mass after drying in a $60^{\circ} \mathrm{C}$ oven for at least 48 hours, and the remaining is used for analysis of periphyton total phosphorus, also after drying in a $60^{\circ} \mathrm{C}$ oven for at least 48 hours. TP analysis is done by the Blue Carbon Analytical Laboratory at Florida International University, where the dried and ground TP sample was ashed, acidified with $5 \mathrm{~mL}$ of $0.2 \mathrm{~N} \mathrm{HCl}$ and heated at $80^{\circ} \mathrm{C}$ for thirty minutes before $10 \mathrm{~mL}$ of deionized water was added to each sample. Samples were capped tightly and vortexed before permitted to settle overnight. $1 \mathrm{~mL}$ of prepared sample is mixed with $9 \mathrm{~mL}$ of deionized water and $1 \mathrm{~mL}$ of a reagent prepared from ammonium molybdate, sulfuric acid, ascorbic acid, and potassium antimonyl tartrate before being analyzed with a Shimadzu UV-2101PC spectrophotometer (Shimadzu Corporation, n.d.). Oxidation of diatom samples was according to Hasle \& Fryxell (1970), and a volumetric subsample was dried onto a coverslip and then permanently affixed to microscope slides using Naphrax (Phycotech Inc., n.d.).

Diatom counts were performed by selecting a random starting point on the slide and identifying all diatom valves (one-half of the complete silica shell that surrounds individual diatoms) that enter the field of view along a transect until 500 valves were identified plus any additional valves in the field of view at that point, recording the start and end coordinates on the stage. Relative abundances of each species were also 
calculated by dividing the number of valves of each species found by the total number of valves counted.

\section{Data Analysis}

\begin{tabular}{|l|l|l|}
\hline Hypothesis & $\begin{array}{l}\text { Network } \\
\text { Measure }\end{array}$ & \multicolumn{2}{l|}{ Expected Behavior } \\
$\begin{array}{l}\text { 1: Algal assemblages present in } \\
\text { calcareous periphyton demonstrate a } \\
\text { small-world network structure under } \\
\text { natural (P-limited) conditions. }\end{array}$ & $\begin{array}{l}\text { Degree } \\
\text { Distribution }\end{array}$ & $\begin{array}{l}\text { Absolute value of the } \\
\text { power law exponent, } \gamma, \\
\text { decreases with increasing } \\
\text { mean periphyton TP }\end{array}$ \\
\hline $\begin{array}{l}\text { 2: A subset of the species consistently } \\
\text { found in calcareous periphyton } \\
\text { engineer the network cohesion of } \\
\text { periphyton. }\end{array}$ & Nestedness & $\begin{array}{l}\text { High nestedness in low P } \\
\text { periphyton }\end{array}$ \\
$\begin{array}{l}\text { Mean First- } \\
\text { order Ego Size }\end{array}$ & $\begin{array}{l}\text { Significant change in } \\
\text { value when important } \\
\text { species are removed. }\end{array}$ \\
\hline $\begin{array}{l}\text { 3: The presence of excess P is linked } \\
\text { with the frequency decline of the same } \\
\text { species providing cohesion to } \\
\text { calcareous periphyton identified by } \\
\text { testing (2). }\end{array}$ & $\begin{array}{l}\text { Mean first-order } \\
\text { ego size }\end{array}$ & $\begin{array}{l}\text { Effect of removal } \\
\text { decreases with increasing } \\
\text { P in periphyton. }\end{array}$ \\
\hline
\end{tabular}

Table 2. Network measures tested and expected behaviors of those measures if the null hypothesis were to be rejected.

Species composition data were grouped by year and ranked by periphyton TP. To determine the effects of periphyton mat TP on network structure, I used a sliding window approach, where sets of 10 consecutive TP-ordered samples within the same year were considered at a time when networks were generated (i.e., ranked samples 1-10, 2-11, 3-12 and so on). Species data were then transformed into a binary co-occurrence matrix by means of matrix multiplication, and all values greater than 0 were set to 1 to represent a cooccurrence of two species. Mean TP for each network of 10 sites was calculated and 
used for analysis of how network measures changed with the sliding window gradient. Measures of how species co-occurrence was distributed (degree distribution) and the number of other species with which a species co-occurred within each network (firstorder ego size) were used as the key response variables in these analyses (Bascompte \& Jordano, 2014; Csárdi \& Nepusz, 2006). First order ego size - the number of species within one link of the species being analyzed, including itself - was used as looking at ego sizes between networks incorporates both the number of species and the number of connections in each network.

Using the R library igraph, networks were constructed using the binary cooccurrence matrices (Csárdi \& Nepusz, 2006). Utilizing the included functions for determining power-law fit of degree distributions above the minimum degree in the network per equation 1 and mean first-order ego size, measures of these descriptors of network structure were calculated. Using the e.divisive function from the R library ecp, changepoints in plots of these measurements compared with network TP were identified for each year (James \& Matteson, 2014). Based on mean location of these changepoints, a two-way ANOVA with replication was performed to analyze differences in power law exponent and mean first-order ego size based on year and category of mean TP.

Utilizing the Nestedness for Dummies software, Nestedness based on Overlap and Decreasing Fill (NODF) of all networks were calculated to serve as a measure of overall species interdependence in networks (Strona \& Fattorini, 2014). These data were then imported to $\mathrm{R}$ and matched with the year and mean TP of networks used to calculate NODF index values. As with power-law exponents and mean first-order ego size, changepoints were calculated using the e.divisive function in R and a two-way ANOVA 
with replication was utilized to identify significant differences between groups based on year and TP categorization.

To determine the effects of removing species on networks, mean first-order ego size of networks where a species occurred were compared with the mean first-order ego size of the same networks with the species in question removed and a dummy value added to represent a species which is present but not interacting with any other species in the network. A paired t-test was performed to determine if the difference between the two measurements was significantly different from 0 , and if so, the species identity was recorded. For those species, changepoints for the difference between means were calculated and two-way ANOVA with replication was performed as with nestedness and mean first-order ego size. Additionally, the general effects of mean TP in each network on frequency of each of the identified species was observed to see if there was a relationship between mean TP and the frequency of diatom species occurrence in networks.

\section{Results}

There was no significant change in how species connections were distributed within networks with increasing mean periphyton TP. In other words, community structure did not completely break down with increasing TP. Second, nestedness (and thus, species interdependence) decreased in response to increasing mean periphyton TP, and the single removal of most species had little effect on how connected the rest of the network was. Third, most species identified as having a significant effect on network structure through removal were species whose frequencies increased with mean 
periphyton TP, including Encyonema evergladianum, which has previously been identified as an indicator of low TP (Mazzei \& Gaiser, 2017; Slate \& Stevenson, 2007).

\begin{tabular}{|l|l|l|l|l|l|}
\hline Year & $\begin{array}{l}\text { Number of } \\
\text { sites }\end{array}$ & $\begin{array}{l}\text { Mean TP } \\
(\mu \mathrm{g} / \mathrm{g})\end{array}$ & $\begin{array}{l}\text { Mean dry } \\
\text { mass }(\mathrm{g})\end{array}$ & $\begin{array}{l}\text { Minimum } \\
\text { species } \\
\text { richness }\end{array}$ & $\begin{array}{l}\text { Maximum } \\
\text { species } \\
\text { richness }\end{array}$ \\
\hline 2007 & 86 & $147(114)$ & $233(337)$ & 7 & 34 \\
\hline 2008 & 112 & $214(130)$ & $101(220)$ & 8 & 45 \\
\hline 2009 & 107 & $144(92)$ & $182(253)$ & 7 & 32 \\
\hline 2010 & 111 & $134(79)$ & $149(203)$ & 7 & 55 \\
\hline 2011 & 87 & $163(114)$ & $268(381)$ & 6 & 37 \\
\hline 2012 & 81 & $236(102)$ & $80(126)$ & 7 & 29 \\
\hline 2013 & 94 & $112(64)$ & $139(213)$ & 7 & 35 \\
\hline 2014 & 109 & $138(126)$ & $245(354)$ & 6 & 30 \\
\hline 2015 & 112 & $208(201)$ & $315(623)$ & 5 & 31 \\
\hline 2016 & 108 & $176(159)$ & $64(81)$ & 7 & 33 \\
\hline
\end{tabular}

Table 3. Table describing the distribution of data utilized in analyses. Specifically, with regards to the number of sites, mean sample periphyton mat TP, mean periphyton sample dry mass, and minimum and maximum sample species richness.

1. Power-Law Structure of Degree Distribution.

Changepoint analysis suggests that if there is a difference between groups in the exponent of power-law descriptions of degree distribution above $\mathrm{x}_{\min }$ in the networks generated, that those differences would be found based on mean changepoints of 100.34 +/- $41 \mu \mathrm{g} / \mathrm{g}$ and $206.77+/-56 \mu \mathrm{g} / \mathrm{g}$ TP (Figure 2). Indeed, mean exponent absolute values of $2.22+/-0.24,2.22+/-0.27$, and $2.20+/-0.25$ were found for those groups, reflecting a small decrease in how rapidly probability distributions fell. However, two-way ANOVA analysis with replication of exponent values demonstrated that these differences between groups based on mat TP were not significant $(F(2,17)=0.808, p=0.446)$. Significant effects were observed based on year and the interaction between year and mat TP grouping. 


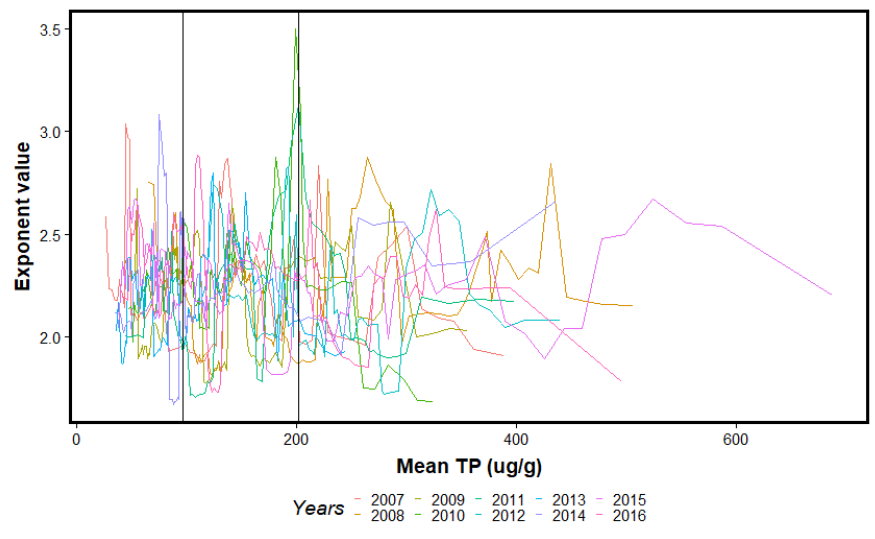

Figure 2. Power law exponent along a gradient of network mean TP $(\mu \mathrm{g} / \mathrm{g})$. The value $(\gamma)$ that fits equation 1 for the degree distribution of each network above some minimum degree. Vertical lines indicate the mean first and last changepoint in the plot for all years. While breakpoints in individual years are significant for each year at $\mathrm{p}<0.05$, a two-way ANOVA with replication indicates that mean exponent value is not significantly different between groups across years $(\mathrm{TP}: \mathrm{F}(2,17)=0.808, \mathrm{p}=0.446$, Years: $\mathrm{F}(9,17)=3.02$, $\mathrm{p}<0.01)$.

2. Network Nestedness and Species Connection.

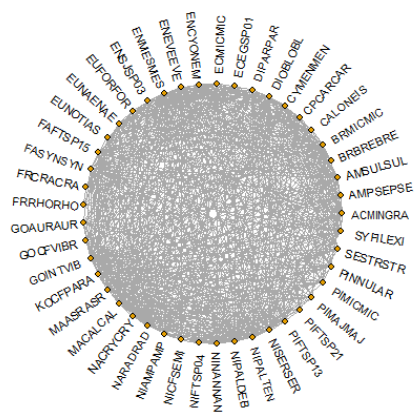

Figure 3. A network generated utilizing data from 2007 with a mean TP of $93.7 \mu \mathrm{g} \mathrm{TP} / \mathrm{g}$ periphyton dry mass. The network contains 45 nodes (taxa) and 527 connections between nodes. Taxon codes are used as labels for each node. 


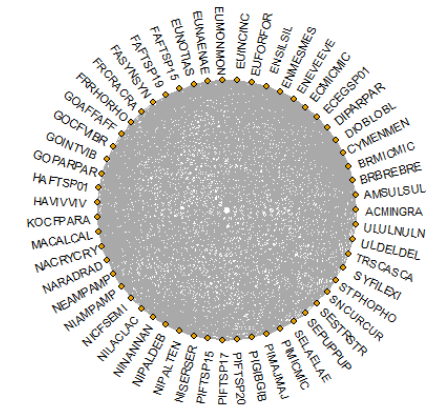

Figure 4. A network generated using data from 2007 with a mean TP of $273.6 \mu \mathrm{g} \mathrm{TP} / \mathrm{g}$ periphyton dry mass. The network contains 55 nodes (taxa) and 826 connections between nodes. Taxon codes are used as labels for each node.

Using changepoint analysis based on the relationship between NODF index values and mean TP in networks, mean locations of changepoints were identified as $83.12+/-48 \mu \mathrm{g} / \mathrm{g}$ and $195.36+/-65 \mu \mathrm{g} / \mathrm{g}$ TP (figure 3). Based on these changepoints, it was determined that the nestedness of networks compared to mean TP in samples used to generate networks differs significantly between low, medium, and high TP groups, per two-way ANOVA with replication and confirmed with a Tukey's post-hoc test $(\mathrm{F}(2,17)=$ 65.30, $\mathrm{p}<0.01)$. Mean NODF values of $57.30+/-6 \mu \mathrm{g} / \mathrm{g}, 54.24+/-6 \mu \mathrm{g} / \mathrm{g}$, and $51.53+/-$ $7 \mu \mathrm{g} / \mathrm{g}$ TP were identified for low, medium, and high mean TP networks across all years. A decline in nestedness indicates that species are more vulnerable to extinction and thus that species composition in low-nestedness networks would be less consistent. A qualitative review of the species of networks at high mean TP supports this assertion. 


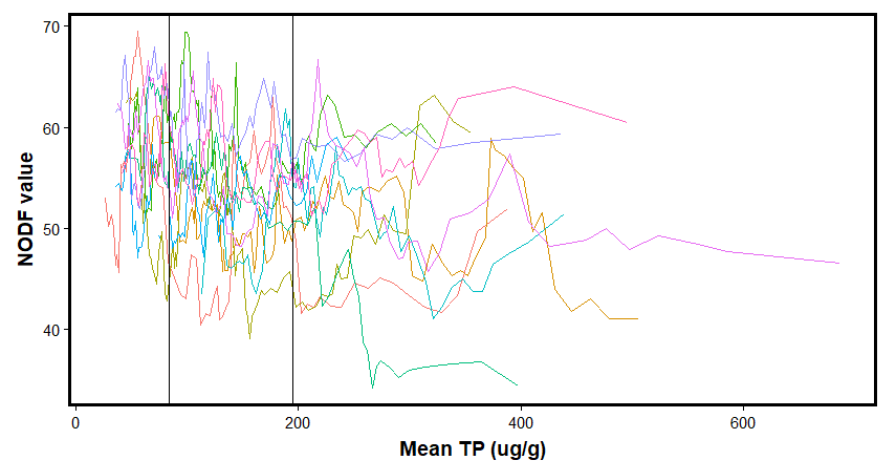

Years $-2007-2008-2010-2011-2013-2015$

Figure 5. NODF compared to mean TP $(\mu \mathrm{g} / \mathrm{g})$. NODF is a measurement of network nestedness indicative of species interdependence. Vertical lines indicate the mean first and last changepoint in the plot for all years. Changepoints in individual years are significant for each year at $p<0.05$, and a mean initial and final breakpoint were calculated from those breakpoints. A two-way ANOVA with replication, followed by Tukey post-hoc test indicates that NODF differs significantly in all combinations of low, medium, and high TP groupings (TP: $\mathrm{F}(2,17)=65.30, \mathrm{p}<0.01$. Years: $\mathrm{F}(9,17)=56.69, \mathrm{p}<0.01)$.

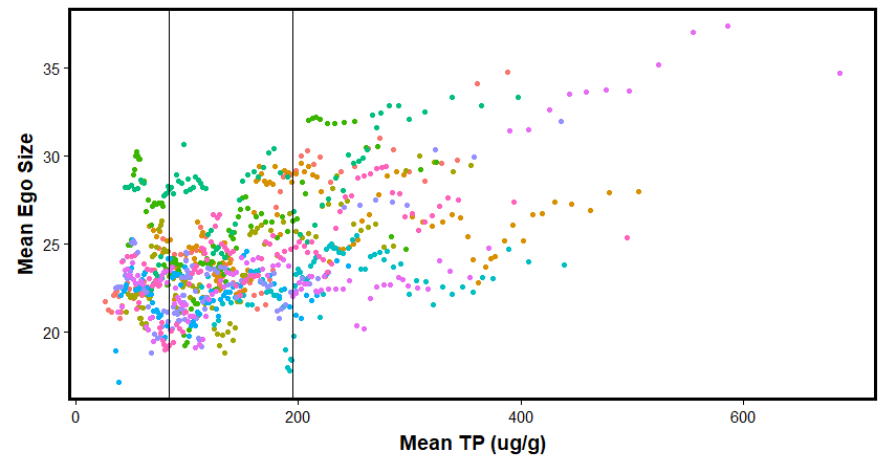

Years : $2007: 2008: 2010: 2011: 2013: 2015$

Figure 6. Mean first-order ego size compared to mean TP $(\mu \mathrm{g} / \mathrm{g})$. First-order ego size of a node is equal to the degree of the node plus one (the node itself). Vertical lines indicate the mean first and last changepoint in the plot for all years. Changepoints in individual years are significant for each year at $\mathrm{p}<0.05$, and a mean initial and final breakpoint were calculated from those breakpoints. A two-way ANOVA with replication indicates that mean first-order ego size differs significantly between low, medium, and high TP groupings, between years, and that the combination of those factors is significant. A Tukey post-hoc test looking at significant differences in means found significant differences between TP groupings at $\mathrm{p}<$ 0.001. (TP: $\mathrm{F}(2,17)=183.94, \mathrm{p}<0.01 ;$ Years: $\mathrm{F}(9,17)=9.85$, $\mathrm{p}<0.01)$ 
In comparing the effects of removing species on networks by t-test between mean first-order ego size of networks with and without each species, a total of 51 species were identified where removal had a greater-than-expected effect on mean first-order ego size (table 1). Several of these species have previously been identified as important indicators of ecosystem health in response to TP. Two-way ANOVA with replication was performed on these 51 species to identify if there were significant differences in the effect of removal on first-order ego size, with Tukey's post-hoc test performed on those species where significant differences were found between groups. Species that had significant differences between TP groups identified include members of motile and non-motile genera of diatoms, such as Achnanthidium, Fragilaria, Mastogloia, and Ulnaria.

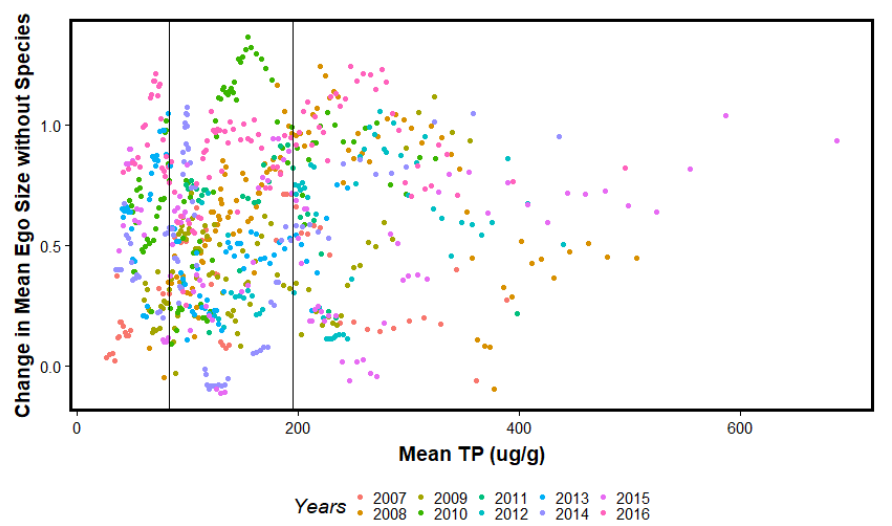

Figure 7. Change in mean ego size for networks that contain the species Achnanthidium minutissimum var gracillima versus the same networks with the node representing A. minutissimum var. gracillima removed. Vertical lines represent mean first and last changepoints for plot in all years. Changepoints in individual years are significant at $p<0.05$ and a mean initial and final changepoint were calculated from those breakpoints. A paired $\mathrm{t}$ test between networks with A. minutissimum var. gracillima in place and removed was performed, finding that the difference was significant $(\mathrm{p}=0.0141)$. An ANOVA with replication determined that there exist statistically significant differences between low, medium, and high TP groups (Years: $F(9,16)=37.90, p<0.01$. TP: $F(2,16)=13.57, p<0.01)$. 


\section{Effects of TP on Frequency of Species}

For species where removal from networks has confirmed statistically significant effects, species frequencies in network were compared to mean TP in samples used to generate the network. Overall trends in species frequency with increasing TP and trends within sections are noted in Table 4. Of the 51 taxa identified with statistically significant effects, species frequency increased with TP in 23 taxa (including Achnanthidium minutissimum var. gracillima, Encyonopsis floridana, Nitzschia amphibia and Ulnaria delicatissima), decreased in 13 taxa (including Amphora sulcata, Brachysira microcephala, Encyonema evergladianum, and Nitzschia palea var. debilis), and were variable in 15 taxa (including Amphora ovalis, Brachysira brebissonii, Caponea caribbea, and Mastogloia lanceolata) (Table 4).

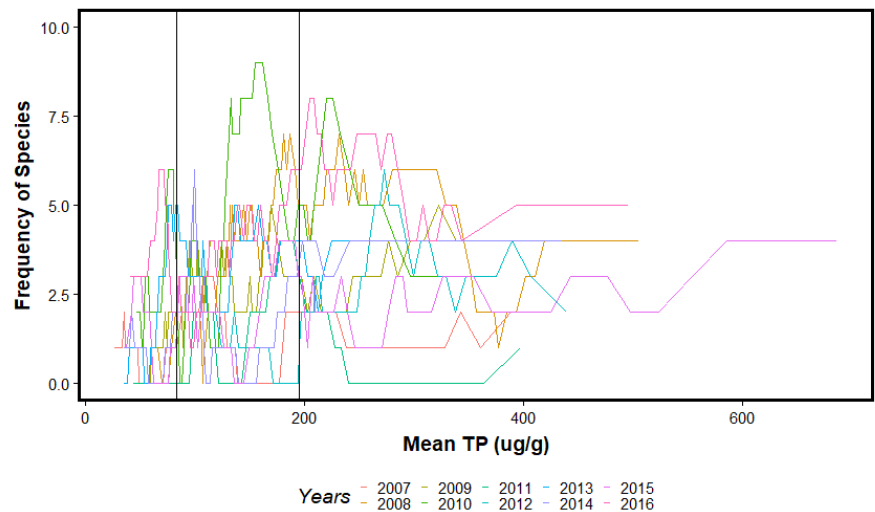

Figure 8. Frequency of diatom taxon Achnanthidium minutissimum var. gracillima in each network for years 2007-2016. Vertical lines indicate changepoints in community as determined by mean ego size in networks including all species. Counter to the hypothesis, there does not seem to be an overall trend of decreasing absolute frequency. Two-way ANOVA with replication identified statistically significant differences between groups based on $\mathrm{TP}(\mathrm{F}(2,17)=101.56, \mathrm{p}<0.01)$ and year $(\mathrm{F}(9,17)=75.43$, $\mathrm{p}<0.01)$. 


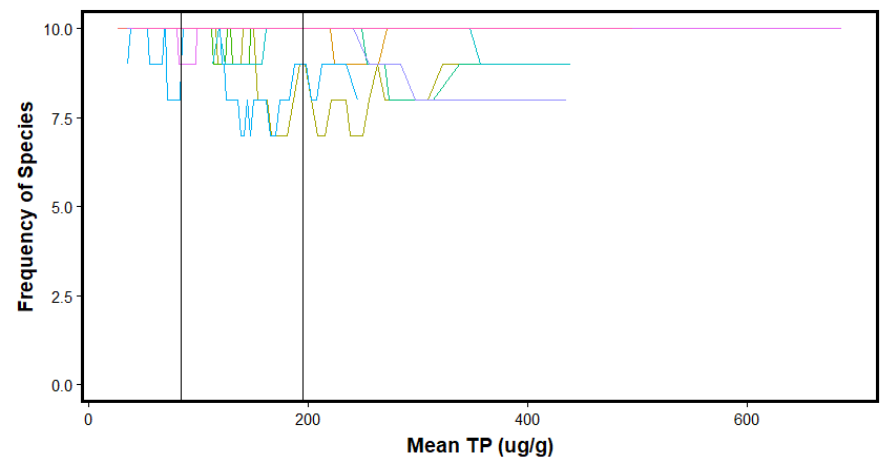

Years $-2007-2008-2010-2011-2013-2013-2015$

Figure 9. Frequency of diatom taxon Brachysira microcephala in each network along a mean TP $(\mu \mathrm{g} / \mathrm{g})$ gradient for years 2007-2016. Vertical lines indicate changepoints in community as determined by mean ego size in networks including all taxa. $(\mathrm{TP}: \mathrm{F}(2,17)=37.21$, $\mathrm{p}<0.01$. Years: $\mathrm{F}(9,17)=50.91, \mathrm{p}<0.01)$

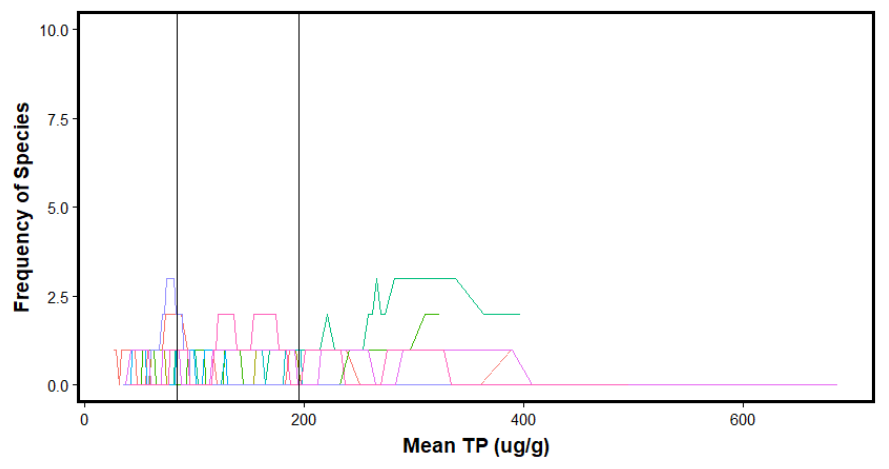

Years $-2007-2008-2010-2011-2013-2015$

Figure 10. Frequency of diatom taxon Caponea caribbea in networks along a mean TP $(\mu \mathrm{g} / \mathrm{g})$ gradient for years 2007-2016. Vertical lines indicate changepoints in community as determined by mean ego size in networks including all taxa. Counter to the hypothesis, there does not seem to be an overall trend of decreasing frequency. (TP: $F(2,17)=.045, \mathrm{p}=0.96$, Years: $\mathrm{F}(9,17)=18.52, \mathrm{p}<0.01$ ) 


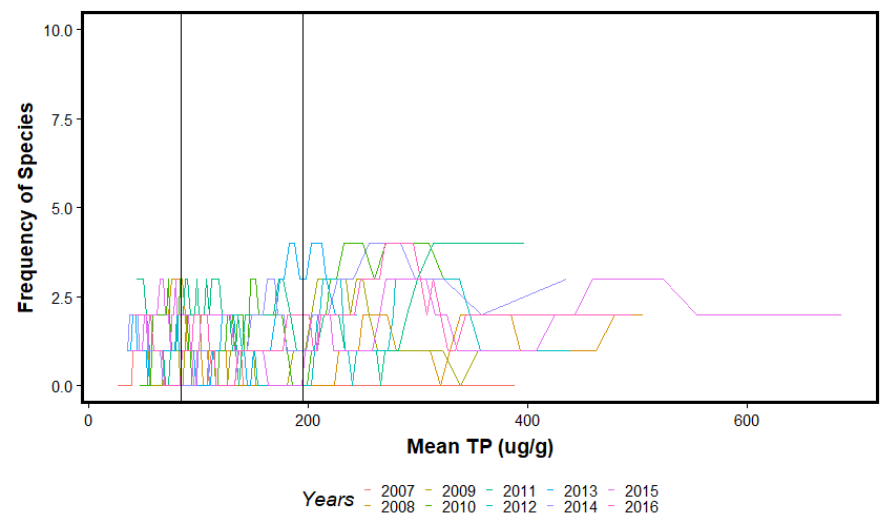

Figure 11. Frequency of diatom taxon Encyonopsis subminuta in each network along a mean TP $(\mu \mathrm{g} / \mathrm{g})$ gradient for years 2007-2016. Vertical lines indicate changepoints in community as determined by mean ego size in networks including all taxa. (TP: $F(2,17)=70.91, p<0.01$. Years: $F(9,17)=22.42$, $p<0.01)$

\begin{tabular}{|c|c|c|c|c|c|c|}
\hline Taxon Name & $\begin{array}{l}\mathrm{T} \text { - } \\
\text { value }\end{array}$ & $\begin{array}{l}\mathrm{P}- \\
\text { value }\end{array}$ & $\begin{array}{l}\text { Average } \\
\text { Frequency } \\
\text { Low TP }\end{array}$ & $\begin{array}{l}\text { Average } \\
\text { Frequency } \\
\text { Medium } \\
\text { TP }\end{array}$ & $\begin{array}{l}\text { Average } \\
\text { Frequency } \\
\text { High TP }\end{array}$ & Trend \\
\hline $\begin{array}{l}\text { Achnanthidium } \\
\text { minutissimum } \\
\text { var. gracillima } \\
\text { (Meister) L. } \\
\text { Bukhtiyarova }\end{array}$ & 2.73 & 0.006 & 1.96 & 2.99 & 3.26 & Increasing \\
\hline $\begin{array}{l}\text { Amphora ovalis } \\
\text { (Kützing) } \\
\text { Kützing }\end{array}$ & 3.24 & 0.002 & 0.03 & 0.08 & 0 & Variable \\
\hline $\begin{array}{l}\text { Amphora sulcata } \\
\text { Schmidt }\end{array}$ & 3.55 & 0.000 & 1.16 & 1.17 & 0.98 & Decreasing \\
\hline $\begin{array}{l}\text { Aulacoseira } \mathrm{cf} \text {. } \\
\text { distans } \\
\text { (Ehrenberg) } \\
\text { Simonsen }\end{array}$ & 2.27 & 0.024 & 0.14 & 0.14 & 0.05 & Decreasing \\
\hline $\begin{array}{l}\text { Aulacoseira cf. } \\
\text { granulata } \\
\text { (Ehrenberg) } \\
\text { Simonsen }\end{array}$ & 2.70 & 0.008 & 0.14 & 0.08 & 0.1 & Decreasing \\
\hline $\begin{array}{l}\text { Brachysira } \\
\text { brebissonii R. } \\
\text { Ross }\end{array}$ & 2.66 & 0.008 & 0.4 & 0.37 & 0.71 & Variable \\
\hline
\end{tabular}




\begin{tabular}{|c|c|c|c|c|c|c|}
\hline $\begin{array}{l}\text { Brachysira } \\
\text { microcephala } \\
\text { (Grunow) } \\
\text { Compère }\end{array}$ & -2.34 & 0.020 & 9.89 & 9.63 & 9.58 & Decreasing \\
\hline $\begin{array}{l}\text { Caponea } \\
\text { caribbea A.C. } \\
\text { Podzorski }\end{array}$ & 2.85 & 0.005 & 0.44 & 0.39 & 0.42 & Variable \\
\hline $\begin{array}{l}\text { Craticula } \\
\text { accomodiformis } \\
\text { Lange-Bertalot }\end{array}$ & 2.21 & 0.030 & 0.08 & 0.02 & 0 & Decreasing \\
\hline $\begin{array}{l}\text { Cyclotella iris } \\
\text { Brun \& } \\
\text { Héreibaud }\end{array}$ & 4.46 & 0.000 & 0.05 & 0.02 & 0.03 & Variable \\
\hline $\begin{array}{l}\text { Diploneis puella } \\
\text { (Schumann) } \\
\text { Cleve }\end{array}$ & 2.82 & 0.005 & 0.15 & 0.19 & 0.18 & Variable \\
\hline $\begin{array}{l}\text { Encyonopsis } \\
\text { egsp01 }\end{array}$ & 2.68 & 0.007 & 0.51 & 0.38 & 0.64 & Variable \\
\hline $\begin{array}{l}\text { Encyonopsis } \\
\text { floridana } \\
\text { Krammer }\end{array}$ & 2.21 & 0.030 & 0 & 0.04 & 0.17 & Increasing \\
\hline $\begin{array}{l}\text { Encyonopsis } \\
\text { subminuta } \\
\text { Krammer \& E. } \\
\text { Reichardt }\end{array}$ & 3.89 & 0.000 & 1.02 & 1.02 & 1.91 & Increasing \\
\hline $\begin{array}{l}\text { Encyonema cf. } \\
\text { evergladianum } \\
\text { Krammer }\end{array}$ & 2.31 & 0.022 & 0.14 & 0.35 & 0.35 & Increasing \\
\hline $\begin{array}{l}\text { Encyonema } \\
\text { evergladianum } \\
\text { Krammer }\end{array}$ & -2.22 & 0.027 & 9.95 & 9.84 & 9.42 & Decreasing \\
\hline $\begin{array}{l}\text { Encyonema } \\
\text { ftsp04 }\end{array}$ & 2.26 & 0.025 & 0.09 & 0.18 & 0.01 & Variable \\
\hline $\begin{array}{l}\text { Encyonema } \\
\text { silesiacum var. } \\
\text { elegans } \\
\text { Krammer }\end{array}$ & 2.17 & 0.030 & 2.19 & 2.74 & 4.1 & Increasing \\
\hline $\begin{array}{l}\text { Encyonema } \\
\text { silesiacum } \\
\text { (Bleisch) D.G. } \\
\text { Mann }\end{array}$ & 3.21 & 0.001 & 0.19 & 0.67 & 1.23 & Increasing \\
\hline $\begin{array}{l}\text { Encyonema } \\
\text { sjsp03 }\end{array}$ & 4.29 & 0.000 & 2 & 1.46 & 1.28 & Decreasing \\
\hline Eunotia egsp01 & 2.09 & 0.037 & 0.16 & 0.24 & 0.45 & Increasing \\
\hline
\end{tabular}




\begin{tabular}{|c|c|c|c|c|c|c|}
\hline $\begin{array}{l}\text { Eunotia flexuosa } \\
\text { (Brébisson ex } \\
\text { Kützing) Kützing }\end{array}$ & 2.37 & 0.018 & 0.27 & 0.91 & 2.24 & Increasing \\
\hline $\begin{array}{l}\text { Eunotia formica } \\
\text { Ehrenberg }\end{array}$ & 2.02 & 0.044 & 0.21 & 0.31 & 0.39 & Increasing \\
\hline $\begin{array}{l}\text { Eunotia naegelii } \\
\text { Migula }\end{array}$ & 2.73 & 0.006 & 0.28 & 0.74 & 2.07 & Increasing \\
\hline $\begin{array}{l}\text { Fragilaria } \text { cf. } \\
\text { tenera }(\mathrm{W} . \text { Smith) } \\
\text { Lange-Bertalot }\end{array}$ & 1.97 & 0.050 & 0.08 & 0.26 & 0.48 & Increasing \\
\hline Fragilaria ftsp16 & 2.07 & 0.039 & 0.04 & 0.26 & 0.28 & Increasing \\
\hline $\begin{array}{l}\text { Fragilariforma } \\
\text { virescens var. } \\
\text { capitata (Østrup) } \\
\text { Czarnecki }\end{array}$ & 1.97 & 0.049 & 0.09 & 0.28 & 0.25 & Variable \\
\hline $\begin{array}{l}\text { Frustulia } \\
\text { crassinervia } \\
\text { (Brébisson ex W. } \\
\text { Smith) Lange- } \\
\text { Bertalot \& } \\
\text { Krammer }\end{array}$ & 2.83 & 0.005 & 0.46 & 0.26 & 0.55 & Variable \\
\hline $\begin{array}{l}\text { Gomphonema } \\
\text { affine Kützing }\end{array}$ & 2.38 & 0.018 & 0.31 & 0.19 & 0.45 & Variable \\
\hline $\begin{array}{l}\text { Gomphonema } c f \text {. } \\
\text { vibrioides E. } \\
\text { Reichardt \& } \\
\text { Lange-Bertalot }\end{array}$ & 3.58 & 0.000 & 0.58 & 1.34 & 1.63 & Increasing \\
\hline $\begin{array}{l}\text { Gomphonema } \\
\text { gracile } \\
\text { Ehrenberg }\end{array}$ & 2.41 & 0.016 & 0.44 & 0.34 & 0.29 & Decreasing \\
\hline $\begin{array}{l}\text { Mastogloia } \\
\text { calcarea S.S. } \\
\text { Lee, E. E. } \\
\text { Gaiser, B. Van } \\
\text { de Vijver, M.B. } \\
\text { Edlund and } \\
\text { Spaulding }\end{array}$ & -2.13 & 0.033 & 8.37 & 8.86 & 9.14 & Increasing \\
\hline $\begin{array}{l}\text { Mastogloia } \\
\text { lanceolata } \\
\text { Thwaites ex W. } \\
\text { Smith }\end{array}$ & 2.60 & 0.010 & 0.33 & 0.39 & 0.23 & Variable \\
\hline $\begin{array}{l}\text { Navicula } \\
\text { densilineolata } \\
\text { (Lange-Bertalot) } \\
\text { Lange-Bertalot }\end{array}$ & 3.27 & 0.001 & 0.05 & 0.06 & 0.17 & Increasing \\
\hline
\end{tabular}




\begin{tabular}{|c|c|c|c|c|c|c|}
\hline $\begin{array}{l}\text { Navicula } \\
\text { radiosafallax }\end{array}$ & 2.28 & 0.023 & 0.21 & 0.49 & 0.63 & Increasing \\
\hline $\begin{array}{l}\text { Lange-Bertalot } \\
\text { Nitzschia } \\
\text { amphibia } \\
\text { Grunow }\end{array}$ & 3.01 & 0.003 & 0.98 & 1.86 & 3.24 & Increasing \\
\hline $\begin{array}{l}\text { Nitzschia cf. } \\
\text { semirobusta }\end{array}$ & 2.55 & 0.011 & 0.33 & 0.76 & 0.5 & Variable \\
\hline $\begin{array}{l}\text { Lange-Bertalot } \\
\text { Nitzschia ftsp16 }\end{array}$ & 2.19 & 0.029 & 0.24 & 0.33 & 0.16 & Variable \\
\hline $\begin{array}{l}\text { Nitzschia } \\
\text { intermedia } \\
\text { Hantzsch ex } \\
\text { Cleve et Grunow }\end{array}$ & 2.15 & 0.033 & 0.21 & 0.32 & 0.37 & Increasing \\
\hline $\begin{array}{l}\text { Nitzschia } \\
\text { microcephala } \\
\text { Grunow }\end{array}$ & 2.28 & 0.026 & 0 & 0.08 & 0 & Variable \\
\hline $\begin{array}{l}\text { Nitzschia nana } \\
\text { Grunow }\end{array}$ & 2.30 & 0.022 & 0.3 & 0.43 & 1.46 & Increasing \\
\hline $\begin{array}{l}\text { Nitzschia palea } \\
\text { var. debilis } \\
\text { (Kützing) } \\
\text { Grunow }\end{array}$ & -2.01 & 0.044 & 9.5 & 9.18 & 8.82 & Decreasing \\
\hline $\begin{array}{l}\text { Nitzschia palea } \\
\text { var. tenuirostris } \\
\text { Grunow }\end{array}$ & 3.09 & 0.002 & 1.03 & 1.18 & 1.91 & Increasing \\
\hline $\begin{array}{l}\text { Pseudostaurosira } \\
\text { brevistriata } \\
\text { (Grunow) D.M. } \\
\text { Williams \& } \\
\text { Round }\end{array}$ & 2.37 & 0.018 & 0.8 & 0.56 & 0.49 & Decreasing \\
\hline $\begin{array}{l}\text { Pinnularia } \\
\text { microstauron } \\
\text { (Ehrenberg) } \\
\text { Cleve }\end{array}$ & 2.31 & 0.021 & 0.57 & 0.55 & 0.98 & Variable \\
\hline $\begin{array}{l}\text { Rhopalodia } \\
\text { gibba } \\
\text { (Eherenberg) O. } \\
\text { Müller }\end{array}$ & 2.16 & 0.031 & 0.09 & 0.25 & 0.43 & Increasing \\
\hline $\begin{array}{l}\text { Sellaphora } \\
\text { laevissima } \\
\text { (Kützing) D.G. } \\
\text { Mann }\end{array}$ & 3.28 & 0.001 & 2.42 & 1.53 & 0.95 & Decreasing \\
\hline
\end{tabular}




\begin{tabular}{|c|c|c|c|c|c|c|}
\hline $\begin{array}{l}\text { Sellaphora } \\
\text { seminulum } \\
\text { (Grunow) D.G. } \\
\text { Mann }\end{array}$ & 2.52 & 0.012 & 0.28 & 0.24 & 0.08 & Decreasing \\
\hline $\begin{array}{l}\text { Sellaphora } \\
\text { stroemii } \\
\text { (Hustedt) H. } \\
\text { Kobayasi }\end{array}$ & 3.74 & 0.000 & 0.74 & 0.63 & 0.46 & Decreasing \\
\hline $\begin{array}{l}\text { Synedra } \\
\text { filiformis var. } \\
\text { exilis Cleve }\end{array}$ & 3.08 & 0.002 & 0.2 & 0.36 & 0.53 & Increasing \\
\hline $\begin{array}{l}\text { Ulnaria } \\
\text { delicatissima (W. } \\
\text { Smith) Aboal \& } \\
\text { P.C. Silva }\end{array}$ & 2.54 & 0.012 & 0.17 & 0.29 & 0.97 & Increasing \\
\hline
\end{tabular}

Table 4. Species with significant differences in mean first-order ego size between otherwise identical networks with and without the species. Results of t-test comparing the mean first-order ego size of networks containing the specified taxon before and after they were removed, average frequency in low, medium, and high TP, and the pattern that the frequency of species follows with increasing TP (increasing, decreasing, or peaking at medium TP).

\section{Discussion}

I found that while networks as a whole do not collapse with increasing TP, there exists a core of species, including previously identified indicator species, which have their role in network structure altered by eutrophication. In some cases, species frequency behaves as expected based on previous abundance-based works, with decreasing frequency in response to increased TP. However, for some species, frequency behaves different to the trends observed for species abundance. This can be either species frequency increasing or displaying variable behavior with eutrophication.

Several diatom species have previously been identified as important indicators of ecosystem health in response to TP in the Everglades Ecosystem (Gaiser et al., 2015; Slate \& Stevenson, 2007). Among these are Achnanthidium minutissimum var. gracillima, Amphora sulcata, Encyonema evergladianum, and Nitzschia palea var. tenuirostris, all of which have previously been found to be indicative of low TP, but my 
analysis found that these species peaked in absolute frequency at a higher TP than previously reported optima (if any). This could be due to the difference in analytical methodology, as Slate \& Stevenson (2007) utilized historical TP data to calculate species optima, Gaiser et al. (2006) identifies changepoints based on TP content of periphyton, and Gaiser (2009) assigned stoplight categories based on the distance between mean values in environmental variables and site values. However, this paper uses species frequency in each network and assigns changepoints based on a statistical analysis of how those frequencies change along the TP gradient. While these studies differ on the location of borders between TP categories and how to identify those points, they do suggest that significant differences in periphyton communities exist and can be identified with multiple methodologies.

\begin{tabular}{|l|l|l|l|}
\hline TP Category & $\begin{array}{l}\text { Gaiser et al. 2006 } \\
\text { (Experimental } \\
\text { multivariate } \\
\text { regression) }\end{array}$ & $\begin{array}{l}\text { Gaiser 2009 } \\
\text { (Gradient study) }\end{array}$ & $\begin{array}{l}\text { This work } \\
\text { (Networks and } \\
\text { species frequency) }\end{array}$ \\
\hline Low & $<178 \mu \mathrm{g} / \mathrm{g}$ TP & $<100 \mu \mathrm{g} / \mathrm{g} \mathrm{TP}$ & $<83 \mu \mathrm{g} / \mathrm{g}$ \\
\hline Medium & $178-458 \mu \mathrm{g} / \mathrm{g}$ TP & $100-200 \mu \mathrm{g} / \mathrm{g} \mathrm{TP}$ & $83-195 \mu \mathrm{g} / \mathrm{g}$ \\
\hline High & $>458 \mu \mathrm{g} / \mathrm{g}$ TP & $>200 \mu \mathrm{g} / \mathrm{g} \mathrm{TP}$ & $>195 \mu \mathrm{g} / \mathrm{g}$ \\
\hline
\end{tabular}

Table 5. Summary of periphyton TP changepoints in the Everglades from previous works (E. Gaiser, 2009; Evelyn E. Gaiser et al., 2006), as well as the changepoints found in this study.

\section{Power-Law Structure of Degree Distribution}

Results indicated that there is no significant effect of TP on the strength with which degree distribution, the number of connections per species versus the probability of finding a species with that number of connections, decays according to Equation 1 above $\mathrm{X}_{\min }$ (Bascompte \& Jordano, 2014; Csárdi \& Nepusz, 2006). Measurements of network characteristics are often interdependent with one characteristic having the 
potential to drastically alter others (Bascompte \& Jordano, 2014). The power-law equation is indicative of the shape of the degree distribution, with the exponent describing how quickly the probability of a species having a specified degree falls in response to increasing the species degree being sought. As there was no significant effect of TP on the exponent alpha with which probability decays, I cannot reject the null hypothesis that mat TP has no effect on the degree distribution of the networks analyzed in this paper. This conclusion thus does not suggest that there is a change in the overarching structure of networks with increasing TP. Based on this, I suggest that there exists no relationship between mean network TP and overall network structure. While specific diatom species are known to play crucial roles in the production and maintenance of the calcareous periphyton of the Everglades (e.g., Mastogloia calcarea, Encyonema evergladianum), it does not appear that there is an over-arching structure to the network that also changes with increasing TP (Evelyn E. Gaiser et al., 2006; La Hée \& Gaiser, 2012; Slate \& Stevenson, 2007).

2. Network Nestedness and Species Connection

Significant changes in network nestedness occur with increasing TP and demonstrates that there are changes occurring within networks as nutrient loads increase beyond those found under natural conditions in the Everglades. The decrease in NODF with increasing TP suggests that networks are becoming less nested and that species interdependence is thus decreasing (Bascompte \& Jordano, 2014; James et al., 2012). Exact causes and consequences of this change are not in the scope of this study, but causes could range from species being less dependent on exudates found in the matrix of the periphyton to changes in metabolic pathways resulting from increased $\mathrm{P}$ availability 
to cosmopolitan generalist species being better able to thrive in nutrient enriched environs and harsher conditions combining to drastically alter which species are present.

\section{Effects of TP on Frequency of Species}

Most species which were identified as being significantly affected by TP in periphyton increased in frequency along the TP gradient. This is consistent with the general concept of the Everglades as a P-limited ecosystem (Gaiser et al., 2011).

However, it does raise questions of how community structure has changed with increasing TP and how that plays into the dissociation and dissolution of periphyton mats. Other research suggests that much of the reason that periphyton dissolves is that the heterotrophic bacterial component of the mat community becomes more active with increased TP and digest the mucilage that holds the various components of the mat together (Gaiser et al., 2015; Johnson et al., 1997).

4. Implications

There have been several different approaches to using periphyton to identify environmental P thresholds in the Everglades since the early $21^{\text {st }}$ century (e.g., Gaiser, 2009; Gaiser et al., 2006, 2004). This work demonstrates that even without the benefits of using abundance data, environmental thresholds are still detectable, and that currently accepted thresholds can even be considered too high, as species frequency is significantly altered in several core species at levels below current accepted abundance-based thresholds. Based on this, one could argue that current Everglades restoration goals do not go far enough to fend off further changes to the periphyton community in the Everglades. 
One potential avenue of further research in this area include looking at how the addition of other components of the periphyton community alters the results reported, especially the heterotrophic bacteria which are implicated in the process of periphyton dissociation. However, this would require the use of expensive molecular techniques to determine the identity of species of bacteria that cannot be cultured (e.g., Pham \& Kim, 2012; Steele et al., 2011), and significant thought on how to accurately standardize count data from this project with count data for soft algae and the suggested molecular work, which do not have the same definition of counting units due to differences in the type of data being generated (single diatom valves versus a variety of colony or filament structures and cell sizes versus how molecular data can take a variety of forms). Similar research in other systems includes soil microbiomes, the microbial communities in lungs of cystic fibrosis patients, and human gut flora (de Menezes et al., 2015; Fernandez et al., 2015; Kurtz et al., 2015; van der Gast et al., 2011)

Other avenues of research may include the effect of three-dimensional mat structure, other environmental variables such as $\mathrm{pH}$, water depth, and precipitation patterns, and even different numbers of samples in network generation on network structure. Each of these may provide distinct useful insights into the way that non-trophic interaction networks influence both communities and emergent properties thereof.

The results I have found suggest that the network dynamics studied do not have strong responses to the mean TP of networks, and thus that a causal relationship between whole-network dynamics and mat cover does not exist. Future utilization of ENA in this context may depend on a more species-centric focus. 


\section{Context}

The Everglades is a highly P-sensitive system which responds dramatically to even low levels of eutrophication (Evelyn E. Gaiser et al., 2006; Noe et al., 2001).

Previous works have demonstrated that periphyton cover, one of the major measures of ecosystem health, is negatively impacted by almost any level of $\mathrm{P}$ enrichment, and with significant effects at levels above $178 \mu \mathrm{g} \mathrm{TP} / \mathrm{g}$ periphyton dry mass and more dramatic effects at $458 \mu \mathrm{g}$ TP/g periphyton dry mass (Evelyn E. Gaiser et al., 2006). This work suggests that such thresholds may be too generous and community health is already being impacted at lower levels ( 83 versus $178 \mu \mathrm{g}$ TP/g periphyton dry mass). Additional work focusing on the effects of species abundance, as well as how other environmental variables effect changes on periphyton communities will aid in further quantifying exactly how TP alters the community which produces the periphyton mats of the Everglades.

\section{BIBLIOGRAPHY}

Alarcon Jr., R. (2004). The Structure of Plant-Pollinator Interactions in Montane Meadow Environments.

Allesina, S., \& Pascual, M. (2008). Network structure, predator - Prey modules, and stability in large food webs. Theoretical Ecology, 1(1), 55-64. https://doi.org/10.1007/s12080-007-0007-8

Astegiano, J., Altermatt, F., \& Massol, F. (2017). Disentangling the co-structure of multilayer interaction networks: Degree distribution and module composition in two-layer bipartite networks. Scientific Reports, 7(1), 1-11. https://doi.org/10.1038/s41598-017-15811-w

Bascompte, J., \& Jordano, P. (2014). Mutualistic Networks. Princeton, New Jersey: Princeton University Press.

Berry, D., \& Widder, S. (2014). Deciphering microbial interactions and detecting keystone species with co-occurrence networks. Frontiers in Microbiology, 5(MAY), 1-14. https://doi.org/10.3389/fmicb.2014.00219 
CaraDonna, P. J., Petry, W. K., Brennan, R. M., Cunningham, J. L., Bronstein, J. L., Waser, N. M., \& Sanders, N. J. (2017). Interaction rewiring and the rapid turnover of plant-pollinator networks. Ecology Letters, 20(3), 385-394. https://doi.org/10.1111/ele.12740

Carey, C. C., Brown, B. L., \& Cottingham, K. L. (2017). The cyanobacterium Gloeotrichia echinulata increases the stability and network complexity of phytoplankton communities. Ecosphere, 8(7), e01830. https://doi.org/10.1002/ecs2.1830

Chick, J. H., Geddes, P., \& Trexler, J. C. (2008). Periphyton mat structure mediates trophic interactions in a subtropical marsh. Wetlands, 28(2), 378-389. https://doi.org/10.1672/07-121.1

Cirri, E., \& Pohnert, G. (2019). Algae-bacteria interactions that balance the planktonic microbiome. New Phytologist, 223(1), 100-106. https://doi.org/10.1111/nph.15765

Cotner, J. B., \& Biddanda, B. A. (2002). Small Players, Large Role: Microbial Influence on Biogeochemical Processes in Pelagic Aquatic Ecosystems. Ecosystems, 5(2), 105-121. https://doi.org/10.1007/s10021-001-0059-3

Csárdi, G., \& Nepusz, T. (2006). The igraph software package for complex network research. InterJournal Complex Systems. Retrieved from http://igraph.org

de Menezes, A. B., Prendergast-Miller, M. T., Richardson, A. E., Toscas, P., Farrell, M., Macdonald, L. M., ... Thrall, P. H. (2015). Network analysis reveals that bacteria and fungi form modules that correlate independently with soil parameters. Environmental Microbiology, 17(8), 2677-2689. https://doi.org/10.1111/14622920.12559

Ellison, A. M., Bank, M. S., Clinton, B. D., Colburn, E. A., Elliott, K., Ford, C. R., ... Webster, J. R. (2005). Loss of Foundation Species: Consequences for the Structure and Dynamics of Forested Ecosystems. Frontiers in Ecology and the Environment, 3(9), 479. https://doi.org/10.2307/3868635

Ewe, S. M. L., Gaiser, E. E., Childers, D. L., Iwaniec, D., Rivera-Monroy, V. H., \& Twilley, R. R. (2006). Spatial and temporal patterns of aboveground net primary productivity (ANPP) along two freshwater-estuarine transects in the Florida Coastal Everglades. Hydrobiologia, 569(1), 459-474. https://doi.org/10.1007/s10750-0060149-5

Fernandez, M., Riveros, J. D., Campos, M., Mathee, K., \& Narasimhan, G. (2015). Microbial "social networks." BMC Genomics, 16(Suppl 11), S6. https://doi.org/10.1186/1471-2164-16-S11-S6

Gaiser, E. (2009). Periphyton as an indicator of restoration in the Florida Everglades. Ecological Indicators, 9(6), S37-S45. https://doi.org/10.1016/j.ecolind.2008.08.004 
Gaiser, E.E., Scinto, L. J., Richards, J. H., Jayachandran, K., Childers, D. L., Trexler, J. C., \& Jones, R. D. (2004). Phosphorus in periphyton mats provides the best metric for detecting low-level $\mathrm{P}$ enrichment in an oligotrophic wetland. Water Research, 38(3), 507-516. https://doi.org/10.1016/j.watres.2003.10.020

Gaiser, Evelyn E., Childers, D. L., Jones, R. D., Richards, J. H., Scinto, L. J., \& Trexler, J. C. (2006). Periphyton responses to eutrophication in the Florida Everglades: Cross-system patterns of structural and compositional change. Limnology and Oceanography, 51(1, part 2), 617-630. https://doi.org/10.4319/lo.2006.51.1_part_2.0617

Gaiser, Evelyn E., Gottlieb, A. D., Lee, S. S., \& Trexler, J. C. (2015). The Importance of Species-Based Microbial Assessment of Water Quality in Freshwater Everglades Wetlands. In J. A. Entry, A. D. Gottleib, K. Jayachandran, \& A. Ogram (Eds.), Microbiology of the Everglades Ecosystem (pp. 115-130). Boca Raton, FL: CRC Press.

Gaiser, Evelyn E., McCormick, P. V., Hagerthey, S. E., \& Gottlieb, A. D. (2011). Landscape Patterns of Periphyton in the Florida Everglades. Critical Reviews in Environmental Science and Technology, 41(S1), 92-120. https://doi.org/10.1080/10643389.2010.531192

Gaiser, Evelyn E., Trexler, J. C., Richards, J. H., Childers, D. L., Lee, D., Edwards, A. L., ... Jones, R. D. (2005). Cascading Ecological Effects of Low-Level Phosphorus Enrichment in the Florida Everglades. Journal of Environment Quality, 34(2), 717. https://doi.org/10.2134/jeq2005.0717

Gotelli, N. J., \& McCabe, D. J. (2002). Species Co-Occurrence: A Meta-Analysis of J. M. Diamond's Assembly Rules Model. Ecology, 83(8), 2091-2096. https://doi.org/10.2307/3072040

Guimarães, P. R., Pires, M. M., Jordano, P., Bascompte, J., \& Thompson, J. N. (2017). Indirect effects drive coevolution in mutualistic networks. Nature, 550(7677), 511514. https://doi.org/10.1038/nature24273

Harpole, W. S., Ngai, J. T., Cleland, E. E., Seabloom, E. W., Borer, E. T., Bracken, M. E. S., ... Smith, J. E. (2011). Nutrient co-limitation of primary producer communities. Ecology Letters, 14(9), 852-862. https://doi.org/10.1111/j.1461-0248.2011.01651.x

Hasle, G. R., \& Fryxell, G. A. (1970). Diatoms: Cleaning and Mounting for Light and Electron Microscopy. Transactions of the American Microscopical Society, 89(4), 469-474. https://doi.org/10.2307/3224555

Hooper, D. U., Adair, E. C., Cardinale, B. J., Byrnes, J. E. K., Hungate, B. A., Matulich, K. L., ... Connor, M. I. (2012). A global synthesis reveals biodiversity loss as a major driver of ecosystem change. Nature, 486(7401), 105-108. https://doi.org/10.1038/nature11118 
Hutchinson, G. E. (1961). The Paradox of the Plankton. The American Naturalist, 95(882), 137-14.

Ings, T. C., Montoya, J. M., Bascompte, J., Blüthgen, N., Brown, L., Dormann, C. F., ... Woodward, G. (2009). Review: Ecological networks - beyond food webs. Journal of Animal Ecology, 78(1), 253-269. https://doi.org/10.1111/j.1365-2656.2008.01460.x

Ives, A. R., \& Carpenter, S. R. (2007). Stability and diversity of ecosystems. Science, 317(5834), 58-62. https://doi.org/10.1126/science.1133258

James, A., Pitchford, J. W., \& Plank, M. J. (2012). Disentangling nestedness from models of ecological complexity. Nature, 487(7406), 227-230. https://doi.org/10.1038/nature11214

James, N. A., \& Matteson, D. S. (2014). ECP: An R package for Nonparametric Multiple Change Point Analysis of Multivariate Data. Journal of Statistical Software, 62(7), 1-25. https://doi.org/10.18637/jss.v062.i07

Jeger, M. J. (2000). Theory and plant epidemiology. Plant Pathology, 49(6), 651-658. https://doi.org/10.1046/j.1365-3059.2000.00522.x

Jeger, M. J., Holt, J., Van Den Bosch, F., \& Madden, L. V. (2004). Epidemiology of insect-transmitted plant viruses: modelling disease dynamics and control interventions. Physiological Entomology, 29(3), 291-304. https://doi.org/10.1111/j.0307-6962.2004.00394.x

Johnson, R. E., Tuchman, N. C., \& Peterson, C. G. (1997). Changes in the Vertical Microdistribution of Diatoms within a Developing Periphyton Mat. Journal of the North American Benthological Society, 16(3), 503-519. Retrieved from http://www.jstor.org/stable/1468140 Accessed:

Koenig, J. E., Spor, A., Scalfone, N., Fricker, A. D., Stombaugh, J., Knight, R., ... Ley, R. E. (2011). Succession of microbial consortia in the developing infant gut microbiome. Proceedings of the National Academy of Sciences, 108(Supplement_1), 4578-4585. https://doi.org/10.1073/pnas.1000081107

Kurtz, Z. D., Müller, C. L., Miraldi, E. R., Littman, D. R., Blaser, M. J., \& Bonneau, R. A. (2015). Sparse and Compositionally Robust Inference of Microbial Ecological Networks. PLoS Computational Biology, 11(5), e1004226. https://doi.org/10.1371/journal.pcbi.1004226

La Hée, J. M., \& Gaiser, E. E. (2012). Benthic diatom assemblages as indicators of water quality in the Everglades and three tropical karstic wetlands. Freshwater Science, 31(1), 205-221. https://doi.org/10.1899/11-022.1

Layeghifard, M., Hwang, D. M., \& Guttman, D. S. (2017). Disentangling Interactions in the Microbiome: A Network Perspective. Trends in Microbiology, 25(3), 217-228. https://doi.org/10.1016/j.tim.2016.11.008 
Layman, C. A., Giery, S. T., Buhler, S., Rossi, R., Penland, T., Henson, M. N., ... Archer, S. K. (2015). A primer on the history of food web ecology: Fundamental contributions of fourteen researchers. Food Webs, 4, 14-24. https://doi.org/10.1016/j.fooweb.2015.07.001

Lee, S. S., Gaiser, E. E., \& Trexler, J. C. (2013). Diatom-based models for inferring hydrology and periphyton abundance in a subtropical karstic wetland: Implications for ecosystem-scale bioassessment. Wetlands, 33(1), 157-173. https://doi.org/10.1007/s13157-012-0363-Z

Lima-Mendez, G., Faust, K., Henry, N., Decelle, J., Colin, S., Carcillo, F., ... Raes, J. (2015). Determinants of community structure in the global plankton interactome. Science, 348(6237), 1262073-1262073. https://doi.org/10.1126/science.1262073

Marazzi, L., \& Gaiser, E. E. (2018). Long-term changes in spatially structured benthic diatom assemblages in a major subtropical wetland under restoration. Inland Waters, 8(4), 434-448. https://doi.org/10.1080/20442041.2018.1500206

Margosian, M. L., Garrett, K. A., Hutchinson, J. M. S., \& With, K. A. (2009). Connectivity of the American Agricultural Landscape: Assessing the National Risk of Crop Pest and Disease Spread. BioScience, 59(2), 141-151. https://doi.org/10.1525/bio.2009.59.2.7

Mazzei, V., \& Gaiser, E. (2017). Scale and spatial consistency of specialization in an endemic and abundant freshwater diatom from the Caribbean Basin. Freshwater Science, 36(3), 542-554. https://doi.org/10.1086/693105

Mazzei, V., \& Gaiser, E. (2018). Diatoms as tools for inferring ecotone boundaries in a coastal freshwater wetland threatened by saltwater intrusion. Ecological Indicators, 88, 190-204. https://doi.org/10.1016/j.ecolind.2018.01.003

Mills, L. S., Soulé, M. E., \& Doak, D. F. (1993). The in Concept Conservation Ecology and Management and policy must explicitly consider the complexity of interactions in natural systems. Bioscience, 43(4), 219-224.

Morales-Castilla, I., Matias, M. G., Gravel, D., \& Araújo, M. B. (2015). Inferring biotic interactions from proxies. Trends in Ecology \& Evolution, 30(6), 347-356. https://doi.org/10.1016/j.tree.2015.03.014

Müller, M. J. I., Neugeboren, B. I., Nelson, D. R., \& Murray, A. W. (2014). Genetic drift opposes mutualism during spatial population expansion. Proceedings of the National Academy of Sciences, 111(3), 1037-1042. https://doi.org/10.1073/pnas.1313285111

Nemergut, D. R., Schmidt, S. K., Fukami, T., O’Neill, S. P., Bilinski, T. M., Stanish, L. F., ... Ferrenberg, S. (2013). Patterns and Processes of Microbial Community Assembly. Microbiology and Molecular Biology Reviews, 77(3), 342-356. https://doi.org/10.1128/MMBR.00051-12 
Noe, G. B., Childers, D. L., \& Jones, R. D. (2001). Phosphorus Biogeochemistry and the Impact of Phosphorus Enrichment: Why Is the Everglades so Unique? Ecosystems, 4(7), 603-624. https://doi.org/10.1007/s10021-001-0032-1

Olesen, J. M., Bascompte, J., Dupont, Y. L., \& Jordano, P. (2006). The smallest of all worlds: Pollination networks. Journal of Theoretical Biology, 240(2), 270-276. https://doi.org/10.1016/j.jtbi.2005.09.014

Olesen, J. M., Bascompte, J., Elberling, H., \& Jordano, P. (2008). TEMPORAL DYNAMICS IN A POLLINATION NETWORK. Ecology, 89(6), 1573-1582. https://doi.org/10.1890/07-0451.1

Ovaskainen, O., Tikhonov, G., Norberg, A., Guillaume Blanchet, F., Duan, L., Dunson, D., ... Abrego, N. (2017). How to make more out of community data? A conceptual framework and its implementation as models and software. Ecology Letters, 20(5), 561-576. https://doi.org/10.1111/ele.12757

Pautasso, M., \& Jeger, M. J. (2014). Network epidemiology and plant trade networks. AoB PLANTS, 6, plu007. https://doi.org/10.1093/aobpla/plu007

Pellissier, L., Albouy, C., Bascompte, J., Farwig, N., Graham, C., Loreau, M., ... Gravel, D. (2018). Comparing species interaction networks along environmental gradients. Biological Reviews, 93(2), 785-800. https://doi.org/10.1111/brv.12366

Pham, V. H. T., \& Kim, J. (2012). Cultivation of unculturable soil bacteria. Trends in Biotechnology, 30(9), 475-484. https://doi.org/10.1016/j.tibtech.2012.05.007

Phycotech Inc. (n.d.). Naphrax 200 mL with Toluene. St. Joseph, MI: Phycotech, Inc. Retrieved from phycotech.com

Pocock, M. J. O., Johnson, O., \& Wasiuk, D. (2011). Succinctly assessing the topological importance of species in flower-pollinator networks. Ecological Complexity, 8(3), 265-272. https://doi.org/10.1016/j.ecocom.2011.06.003

Proulx, S. R., Promislow, D. E. L., \& Phillips, P. C. (2005). Network thinking in ecology and evolution. Trends in Ecology and Evolution, 20(6), 345-353. https://doi.org/10.1016/j.tree.2005.04.004

Reid, R. P., Visscher, P. T., Decho, A. W., Stolz, J. F., Bebout, B. M., Dupraz, C., ... DesMarais, D. J. (2000). The role of microbes in accretion, lamination and early lithification of modern marine stromatolites. Nature, 406(6799), 989-992. https://doi.org/10.1038/35023158

Sabater, S., Vilalta, E., Gaudes, A., Guasch, H., Muñoz, I., \& Romaní, A. (2003). Ecological implications of mass growth of benthic cyanobacteria in rivers. Aquatic Microbial Ecology, 32, 175-184.

Schöb, C., Butterfield, B. J., \& Pugnaire, F. I. (2012). Foundation species and trait-based community assembly. New Phytologist, 196, 824-834. https://doi.org/10.1111/j.1469-8137.2012.04306.x 
Scinto, L. J., \& Reddy, K. R. (2003). Biotic and abiotic uptake of phosphorus by periphyton in a subtropical freshwater wetland. Aquatic Botany, 77, 203-222. https://doi.org/10.1016/S0304-3770(03)00106-2

Shimadzu Corporation. (n.d.). Shimadzu UV-2101PC Spectrophotometer.

Slate, J. E., \& Stevenson, R. J. (2007). THE DIATOM FLORA OF PHOSPHORUSENRICHED AND UNENRICHED SITES IN AN EVERGLADES MARSH. Diatom Research, 22(2), 355-386. https://doi.org/10.1080/0269249X.2007.9705721

Sokol, E. R., Hoch, J. M., Gaiser, E., \& Trexler, J. C. (2014). Metacommunity structure along resource and disturbance gradients in Everglades wetlands. Wetlands, 34(SUPPL. 1), S135-S146. https://doi.org/10.1007/s13157-013-0413-1

Spieles, D. J., \& Mitsch, W. J. (2000). MACROINVERTEBRATE COMMUNITY STRUCTURE IN HIGH- AND LOW-NUTRIENT CONSTRUCTED WETLANDS. Wetlands, 20(4), 716-729. https://doi.org/https://doi.org/10.1672/02775212(2000)020[0716:MCSIHA]2.0.CO;2

Steele, J. A., Countway, P. D., Xia, L., Vigil, P. D., Beman, J. M., Kim, D. Y., ... Fuhrman, J. A. (2011). Marine bacterial, archaeal and protistan association networks reveal ecological linkages. The ISME Journal, 5, 1414-1425. https://doi.org/10.1038/ismej.2011.24

Stevens, D. L., \& Olsen, A. R. (2004). Spatially balanced sampling of natural resources. Journal of the American Statistical Association, 99(465), 262-278. https://doi.org/10.1198/016214504000000250

Stevenson, R. J. (1998). Diatom indicators of stream and wetland stressors in a risk management framework. Environmental Monitoring and Assessment, 51, 107-118.

Stevenson, R. J., Pan, Y., \& van Dam, H. (2010). Assessing environmental conditions in rivers and streams with diatoms. In J. P. Smol \& E. F. Stoermer (Eds.), The Diatoms: Applications for the Environmental and Earth Sciences, 2nd Edition (2nd ed., pp. 57-85). Cambridge, UK: Cambridge University Press.

Strona, G., \& Fattorini, S. (2014). NeD - Nestedness for Dummies. Retrieved from http://ecosoft.alwaysdata.net/

Thompson, J. N. (2006). Mutualistic webs of species. Science, 312(5772), 372-373. https://doi.org/10.1126/science.1126904

Tsai, K.-N., Lin, S.-H., Liu, W.-C., \& Wang, D. (2015). Inferring microbial interaction network from microbiome data using RMN algorithm. BMC Systems Biology, 9, 54. https://doi.org/10.1186/s12918-015-0199-2 
van der Gast, C. J., Walker, A. W., Stressmann, F. A., Rogers, G. B., Scott, P., Daniels, T. W., ... Bruce, K. D. (2011). Partitioning core and satellite taxa from within cystic fibrosis lung bacterial communities. The ISME Journal, 5, 780-791. https://doi.org/10.1038/ismej.2010.175

Wiegand, T., Gunatilleke, S., \& Gunatilleke, N. (2007). Species Associations in a Heterogeneous Sri Lankan Dipterocarp Forest. The American Naturalist, 170(4), E77-E95. https://doi.org/10.1086/521240 


\section{APPENDICES}

Appendix A: Analyses and Figures Code

\section{A.1 Network Graph Labeling}

library(igraph)

g <- g.sim_storage[[70]]

\# laid out as a circle to begin with

la <- layout.circle $(g)$

$\operatorname{par}(\operatorname{mar}=c(8,6,6,6))$

$\operatorname{plot}(\mathrm{g}$, layout=la, vertex.size $=5$, vertex.label="")

\# Apply labels manually

\#Specify $\mathrm{x}$ and y coordinates of labels, adjust outward as desired

$\mathrm{x}=\mathrm{la}[, 1] * 1.3$

$\mathrm{y}=\mathrm{la}[, 2] * 1.3$

\#create vector of angles for text based on number of nodes (flipping the orientation of the words half way around so none appear upside down)

angle $=$ ifelse $(\operatorname{atan}(-(\mathrm{la}[, 1] / \mathrm{la}[, 2])) *(180 /$ pi $)<0,90+\operatorname{atan}(-(\mathrm{la}[, 1] / \mathrm{la}[, 2])) *(180 /$ pi $), 270$

$+\operatorname{atan}(-\mathrm{la}[, 1] / \mathrm{la}[, 2]) *(180 / \mathrm{pi}))$

\#Apply the text labels with a loop with angle as srt

for (i in 1:length $(x))\{$

text $(x=x[i], y=y[i]$, labels=V(g)\$name[i], adj=NULL, pos=NULL, cex=.7, col="black", srt=angle[i], $x p d=T$ )

\} 
\# Code sourced from

https://gist.github.com/ajhmohr/5337a5c99b504e4a243fad96203fa74f

\section{A.2 Plot Theming}

library(ggplot2)

library(ggthemes)

theme_Publication <- function(base_size=14, base_family="helvetica") \{

$\operatorname{library}($ grid $)$

library(ggthemes)

(theme_foundation(base_size=base_size, base_family=base_family)

+ theme(plot.title = element_text(face = "bold",

$$
\text { size }=\operatorname{rel}(1.2), \text { hjust }=0.5),
$$

text $=$ element_text (), panel.background $=$ element_rect $($ colour $=\mathrm{NA})$,

plot.background $=$ element_rect $($ colour $=\mathrm{NA})$, axis.title $=$ element_text $($ face $=$

"bold",size = rel(1)),

axis.title. $y=$ element_text $($ angle $=90, v j u s t=2)$, axis.title $. x=$ element_text $($ vjust $=$ -

$0.2)$

axis.text $=$ element_text (), axis.line $=$ element_line $($ colour="black"),

axis.ticks $=$ element_line (), panel.border $=$ element_rect $($ colour $=$ "black", fill =

NA, size $=2$ ),

panel.grid.major $=$ element_blank (), panel.grid.minor $=$ element_blank () ,

legend.key = element_rect $($ colour = NA $)$, legend.position = "bottom",

legend.direction = "horizontal", legend.key.size= unit $(0.2, " \mathrm{~cm} ")$,

legend.spacing = unit $(0, " \mathrm{~cm} ")$, legend.title = element_text(face="italic"), 


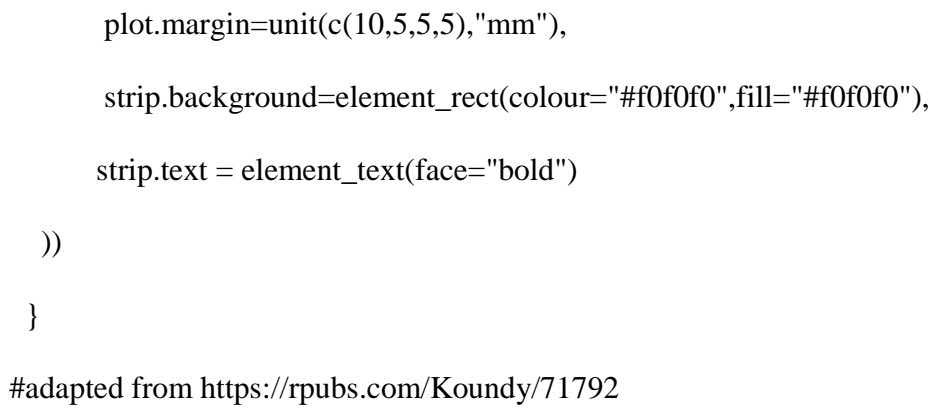


\#' *Data Cleaning Phase*

\# Create dataset that only contains quantitative samples

dataset2 <- dataset[(dataset\$Sample.Quantitative...Y.or.N. == "Y"),]

\# Remove columns containing extraneous/redundant information (replicate number,

\# sample plot area, whether sample is quantitative or not. Also remove relative

\# abundance columns)

dataset3 <- dataset2[ ,-c(3, 14, 19, 53:441)]

\# Remove samples from Loxahatchee and Lake Okeechobee due to differing underlying geology/soil.

dataset4 <- dataset3[!dataset3\$Location == "LOX" \& dataset3\$Location != "LKO",]

\# Remove samples which do not have positive value (or are NA).

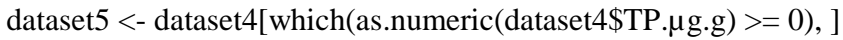

\#'*Write Combined Dataset for backup purposes.*

write.csv(dataset5, " /R/Research

Scripts/Thesis/OriginalData/CombinedQuantData.csv", row.names = FALSE)

$\operatorname{setwd}(\operatorname{dir}=" \sim ")$

\#'End of ImportAndClean.R

\# The output is manually inspected and cleaned for compatibility with planned

\# abundance-related analyses.

\section{A.4 Generating Network Matrices}

\#'*Group data and create matrices (binary)*

\# Libraries

library(igraph) 


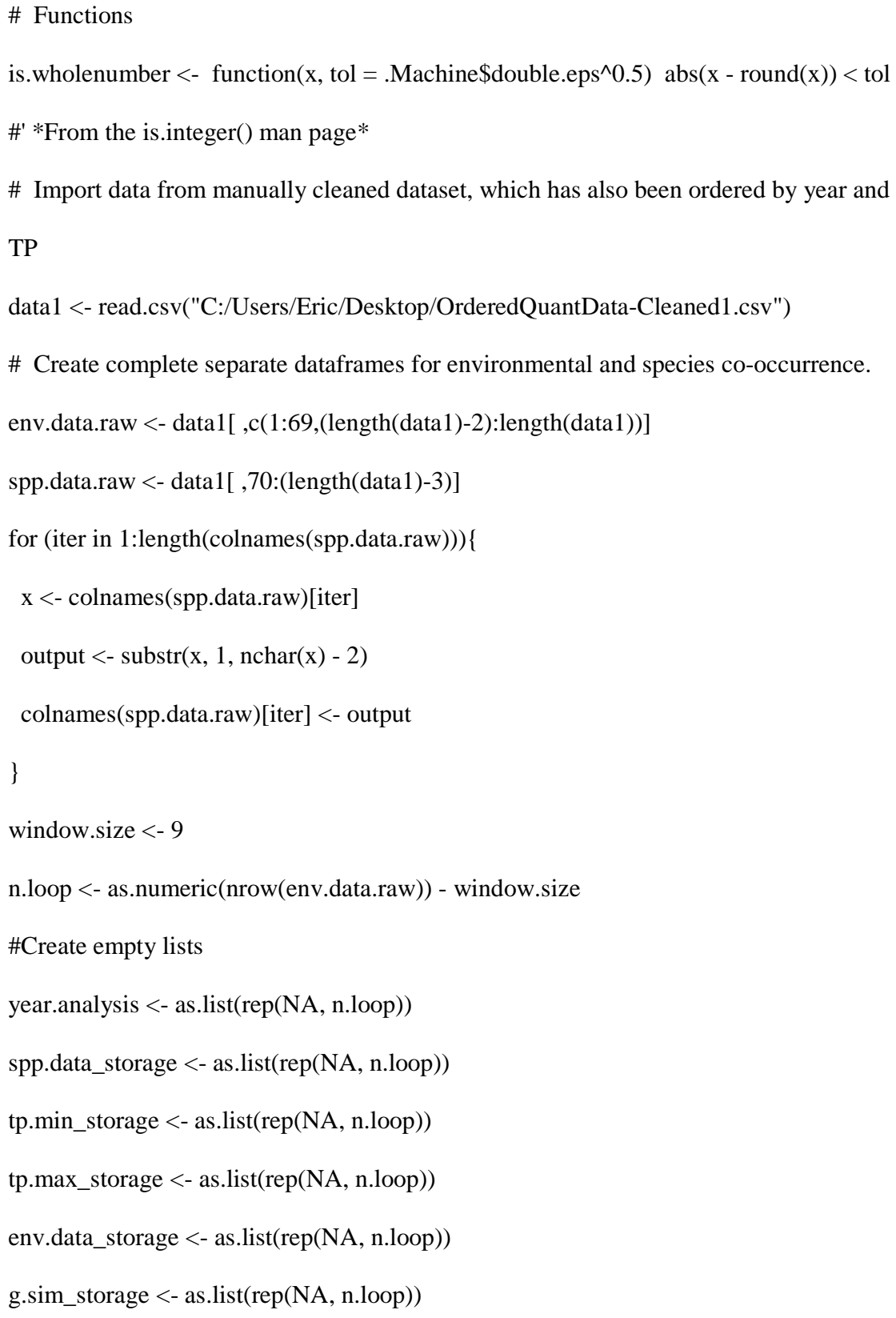




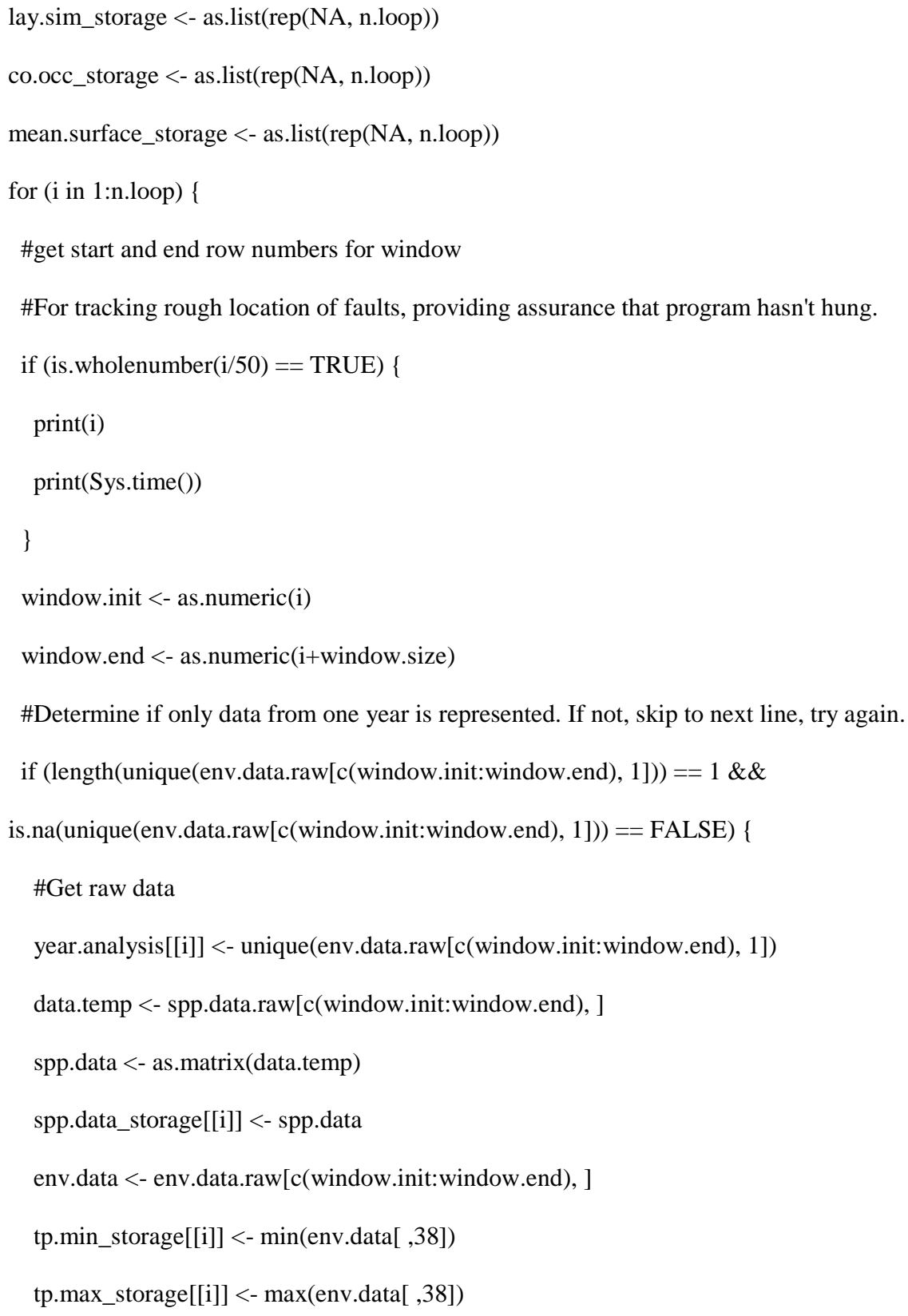




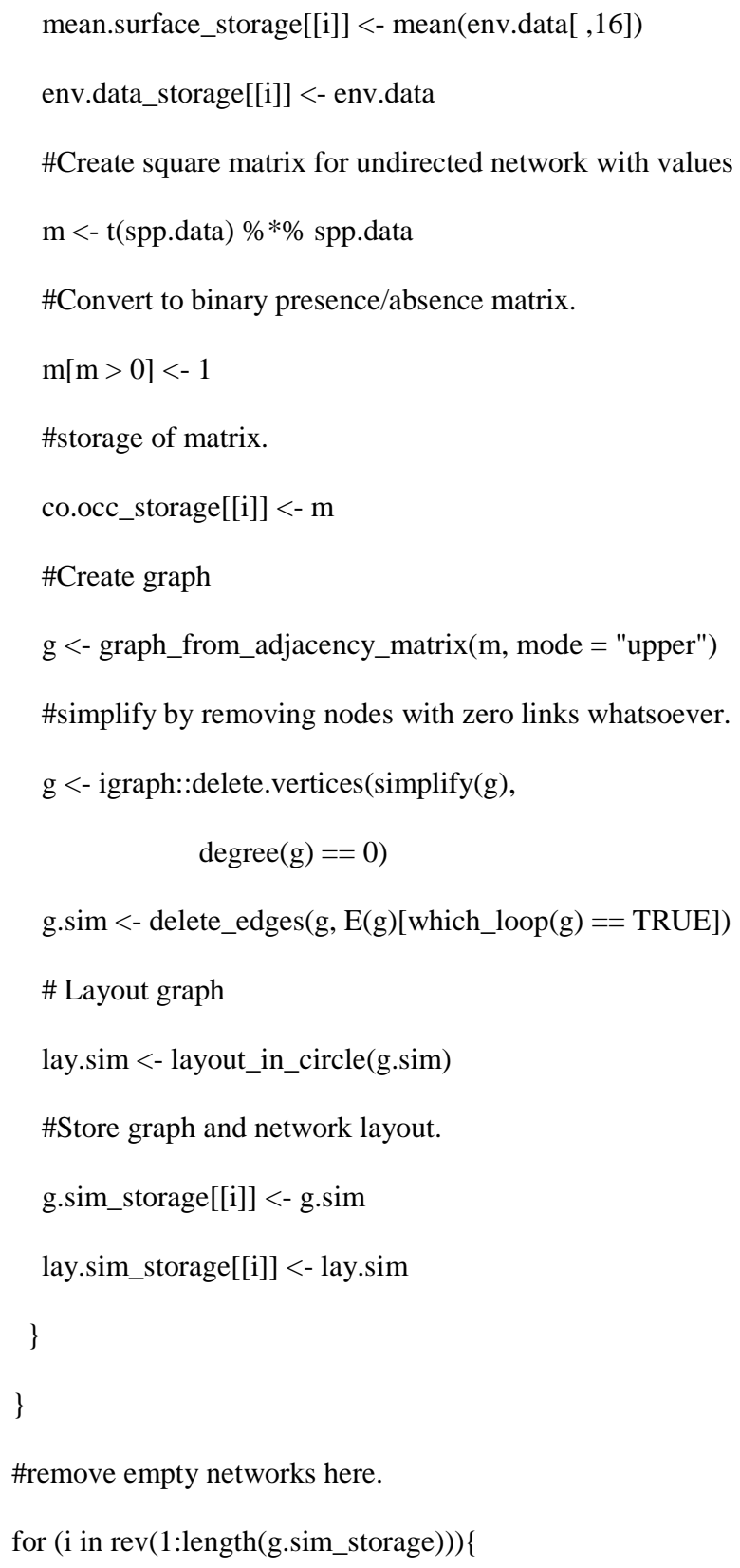




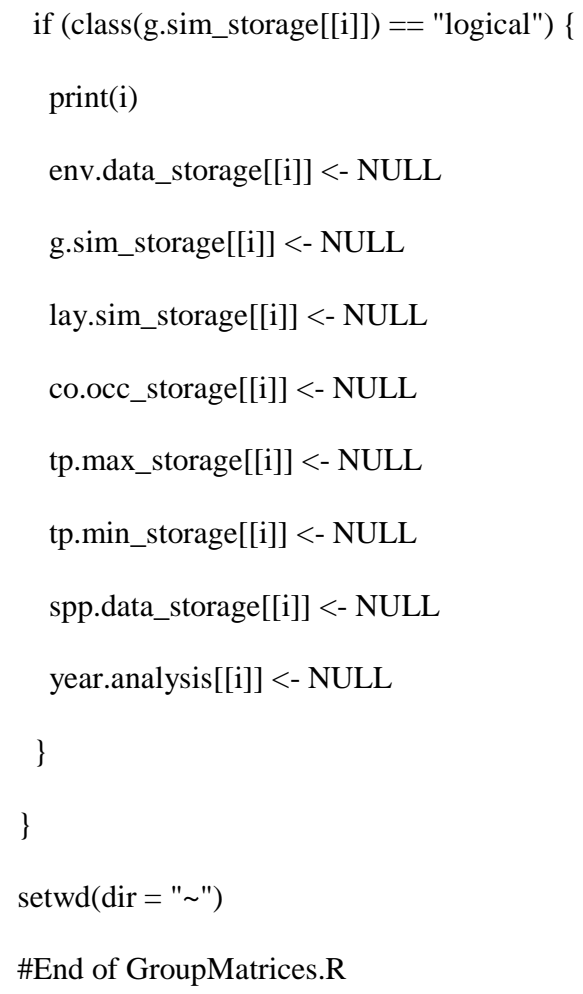




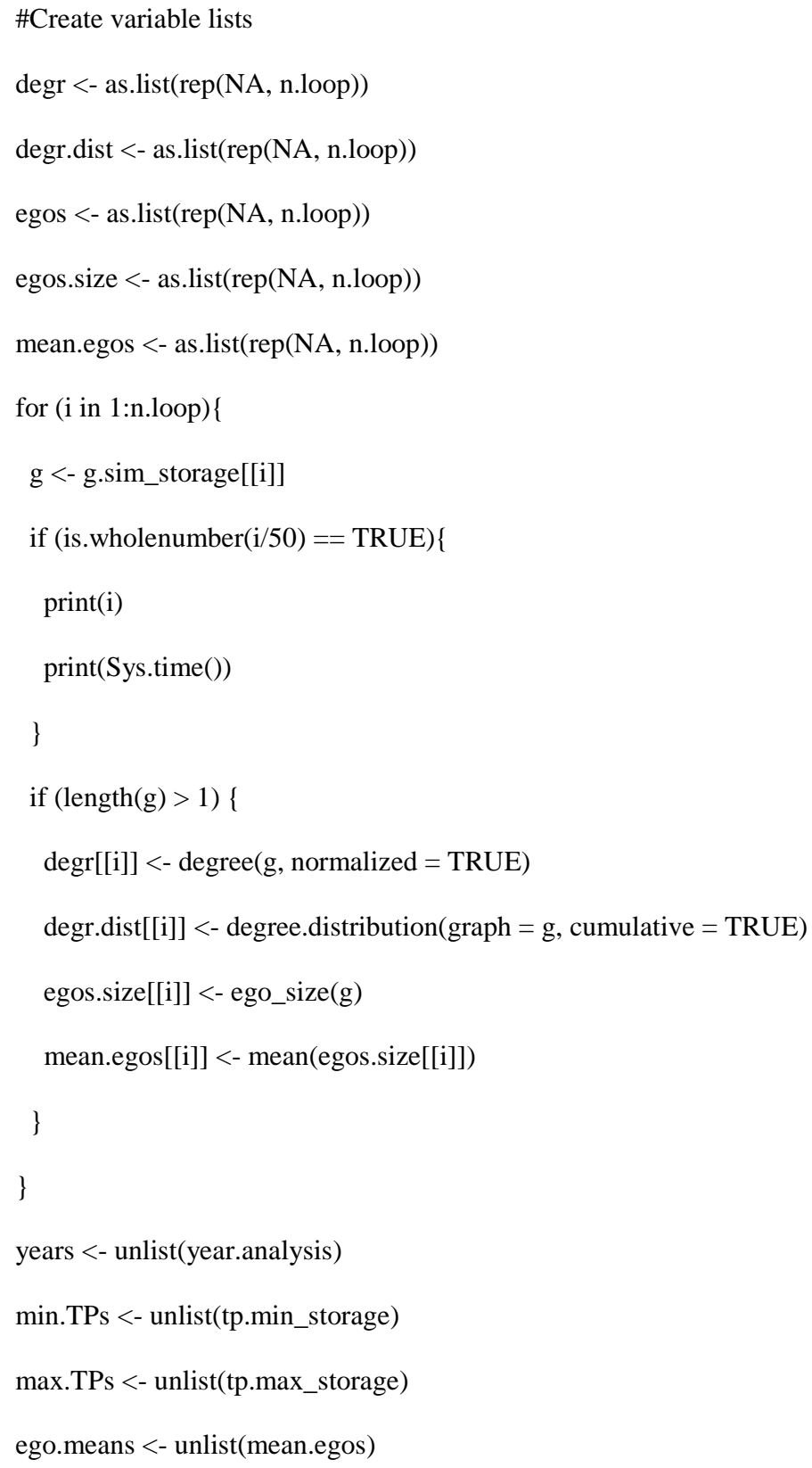




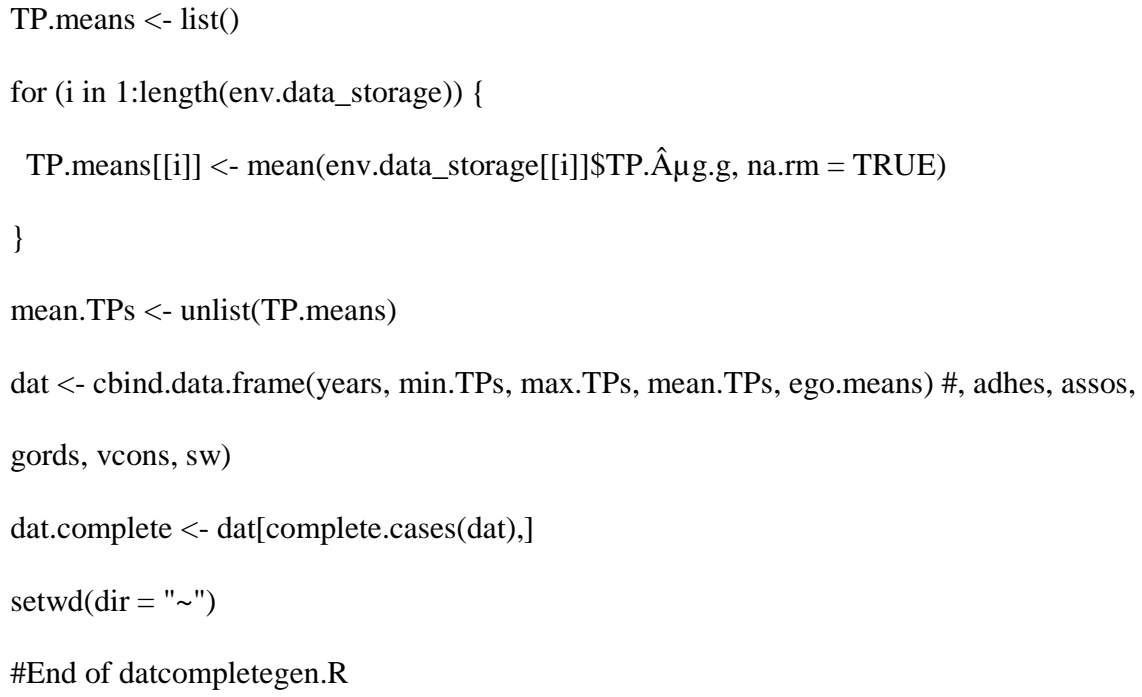




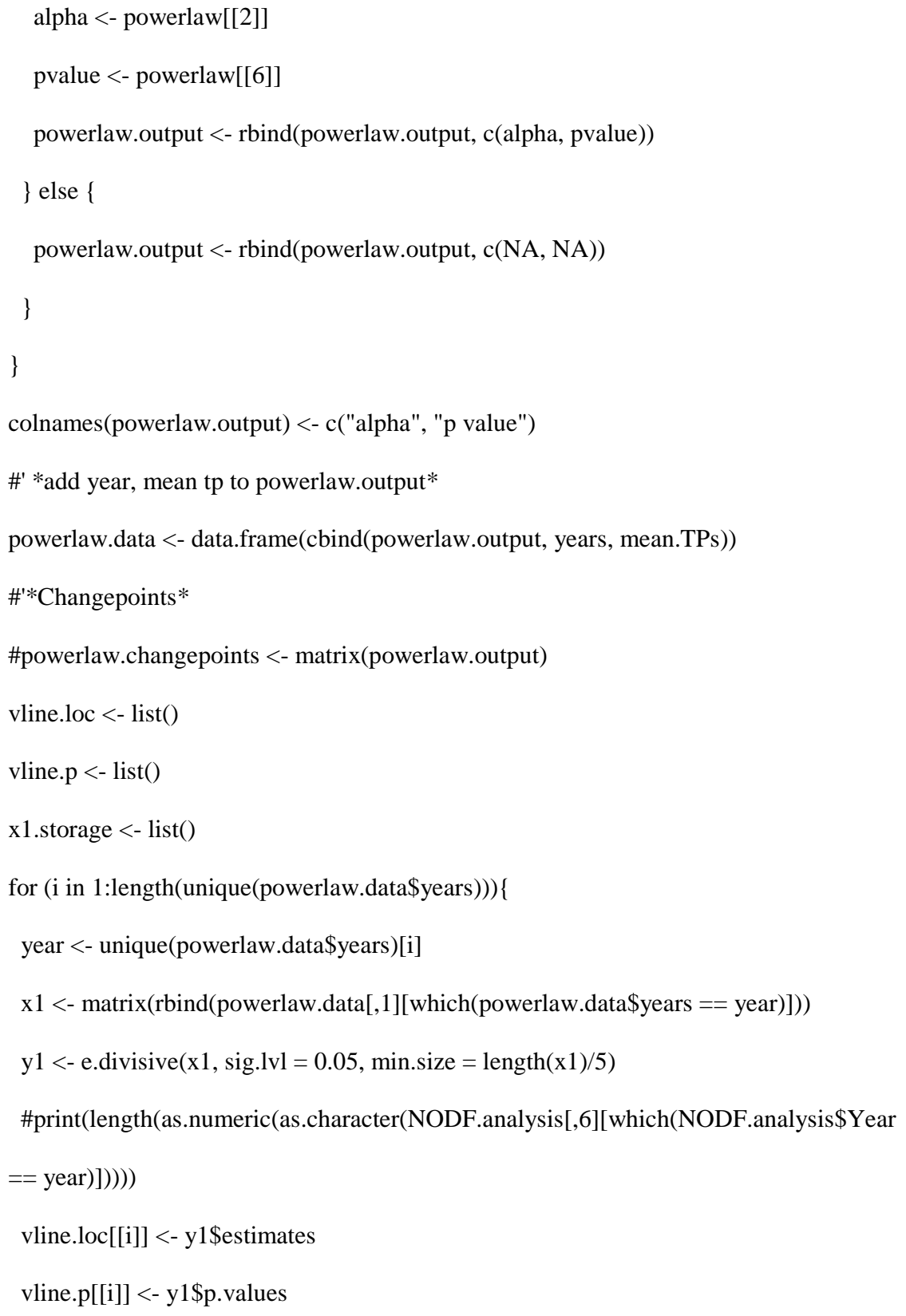




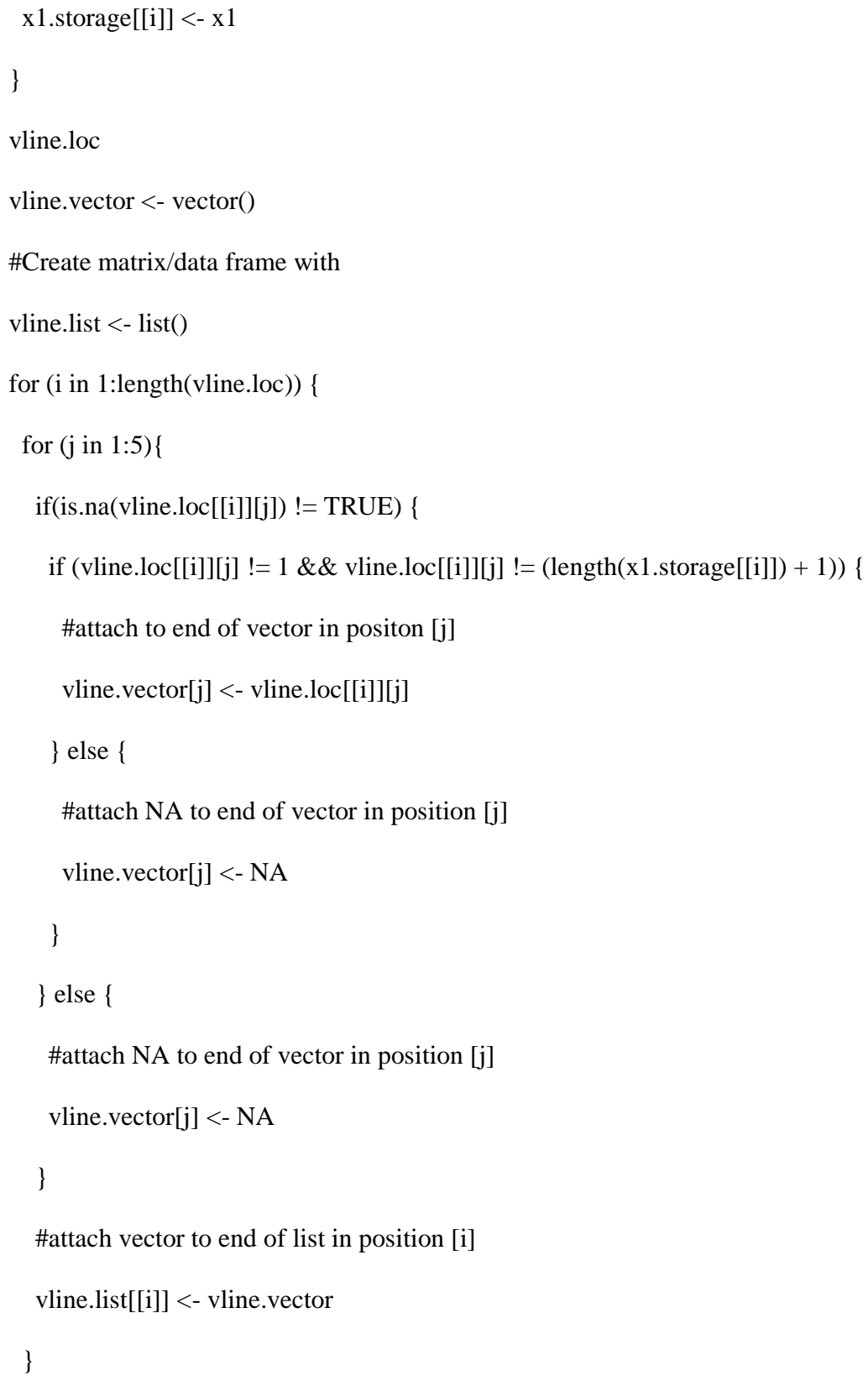




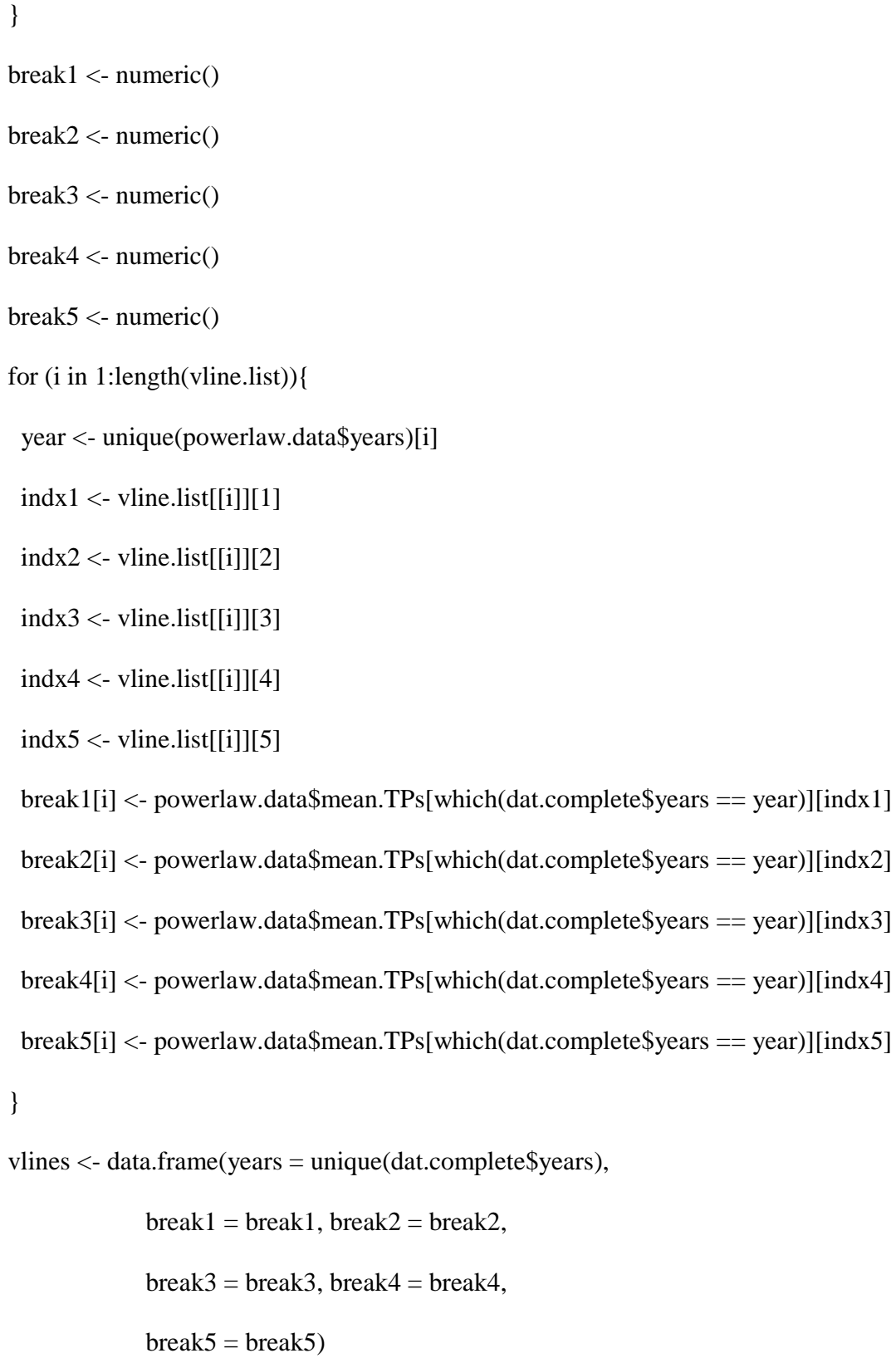




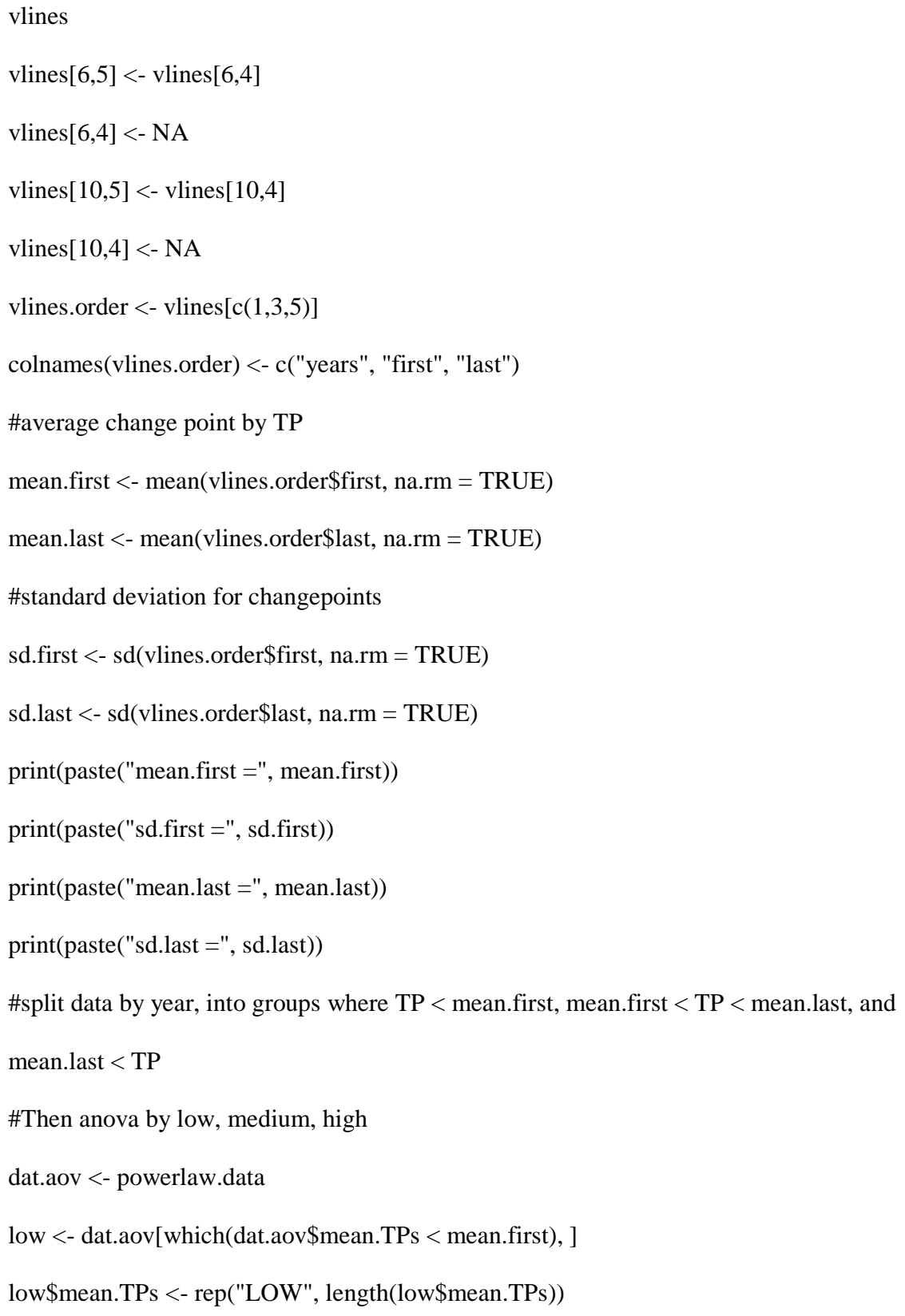




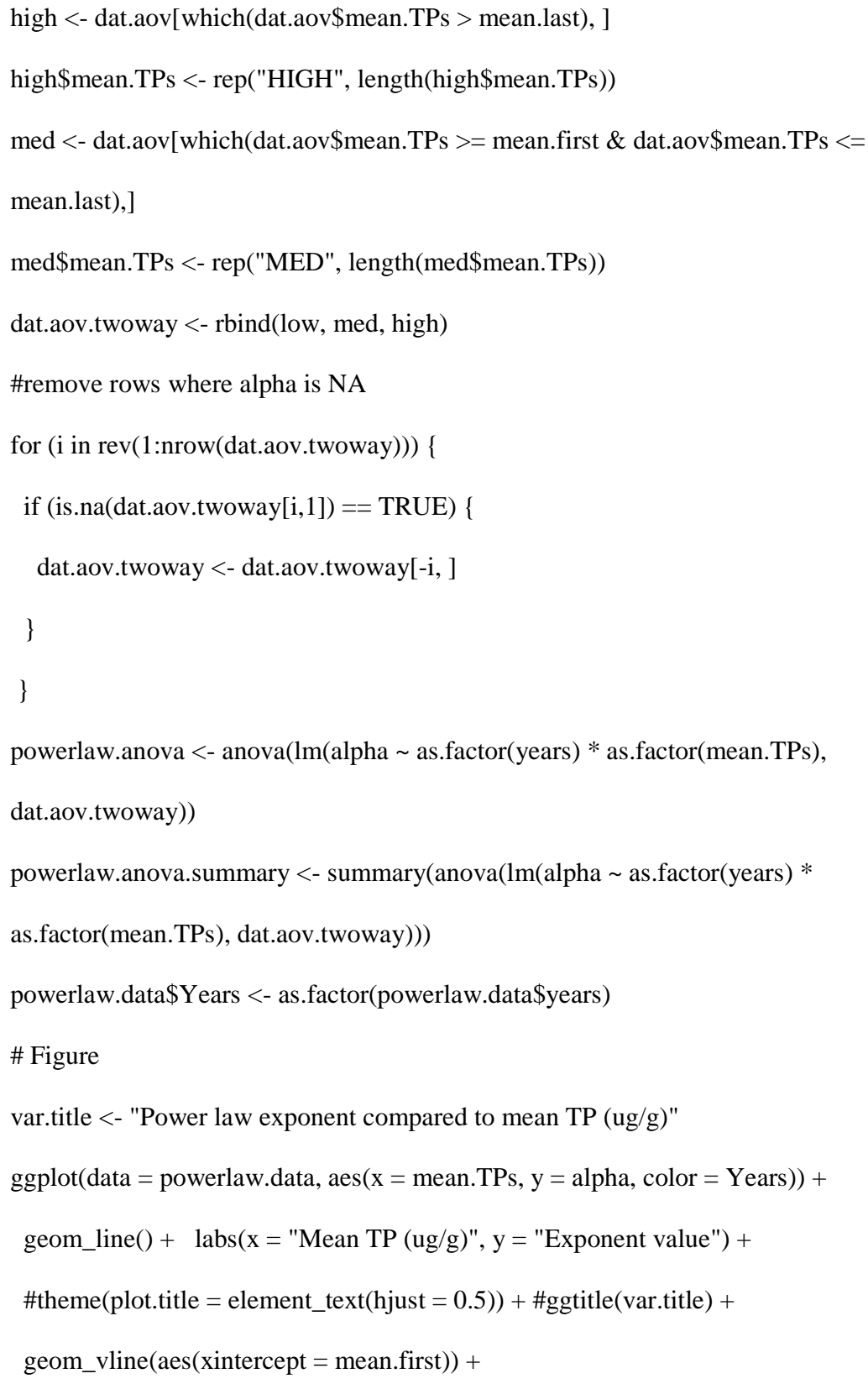




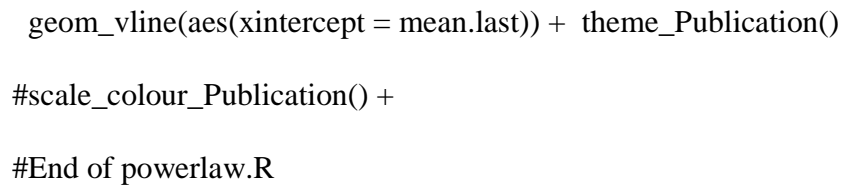




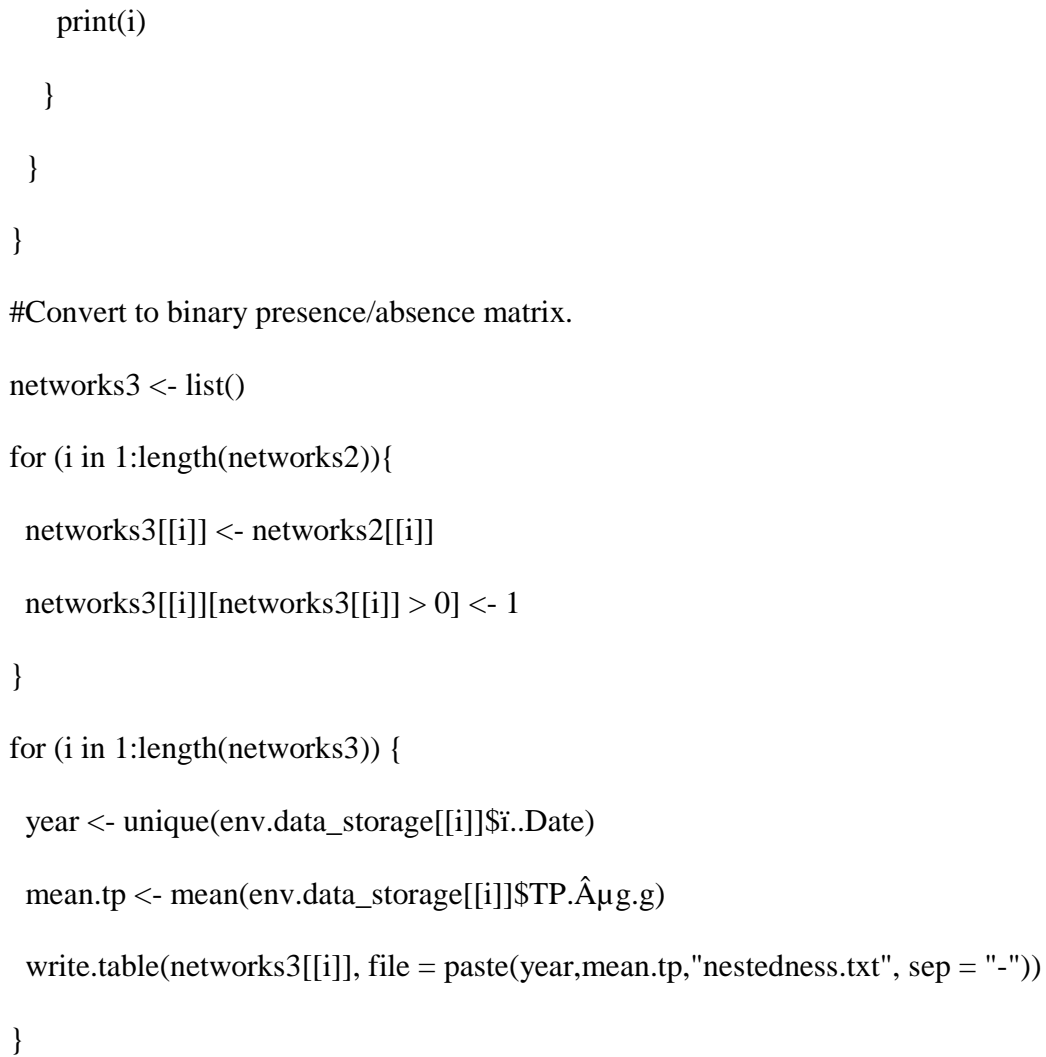


\#Add two columns with year and TP from splitting first column.

\#Get data for columns

NODF.year.tp <- matrix(unlist(strsplit(as.character(NODF.overall[ ,1]), split = "-|ls")),

$\mathrm{ncol}=3$, byrow $=$ TRUE)

colnames(NODF.year.tp) <- c("Year","TP", "remove")

\#Year + TP columns columns

NODF.analysis <- data.frame(cbind(NODF.overall,NODF.year.tp[,1:2]))

head(NODF.analysis)

vline.loc $<-$ list ()

vline.p $<-$ list ()

$\mathrm{x} 2$.storage $<-$ list ()

for (i in 1:length(unique(NODF.analysis\$Year))) \{

year <- unique(NODF.analysis\$Year) $[\mathrm{i}]$

$\mathrm{x} 2<-$

matrix(rbind(as.numeric(as.character(NODF.analysis[,2][which(NODF.analysis\$Year == year)]))))

y2 <- e.divisive $(\mathrm{x} 2, \operatorname{sig} . \operatorname{lvl}=0.05$, min.size $=$ length $(\mathrm{x} 2) / 5)$

\#print(length(as.numeric(as.character(NODF.analysis[,6][which(NODF.analysis\$Year

$==$ (ear)]))))

vline.loc $[[i]]<-y 2$ Sestimates

vline.p[[i]] <- y2\$p.values

$\mathrm{x} 2$.storage $[[\mathrm{i}]]<-\mathrm{x} 2$

\} 


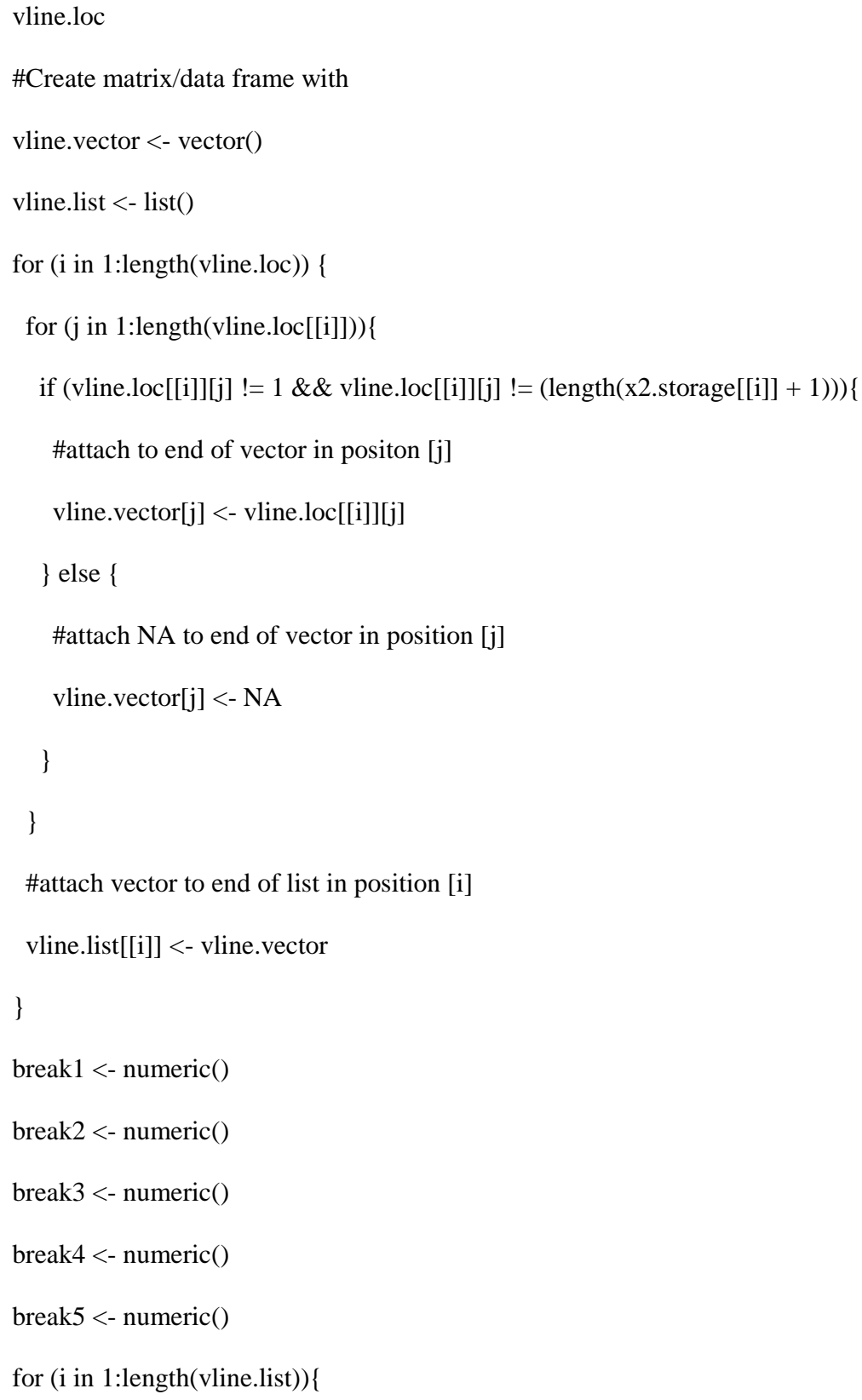




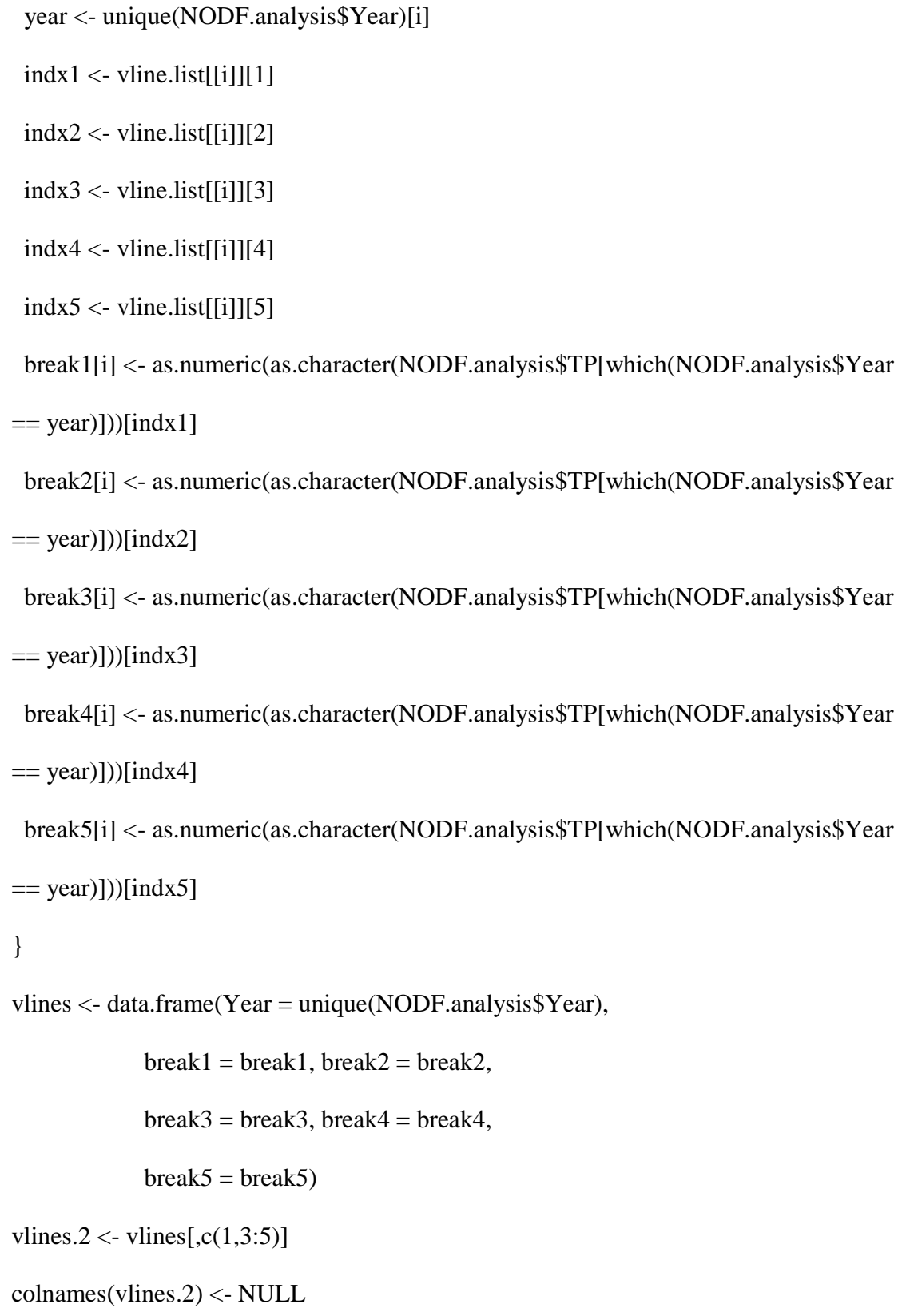




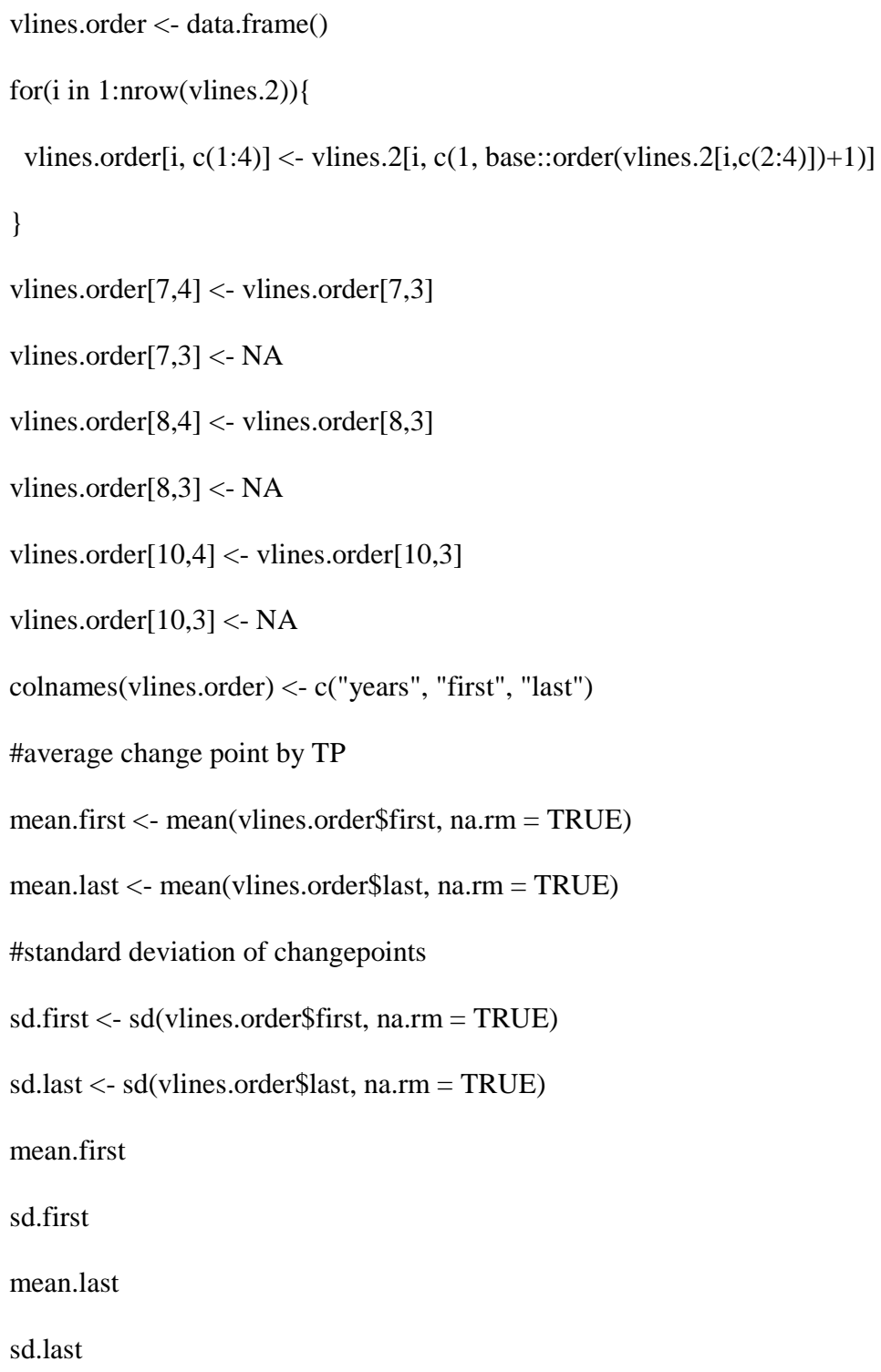




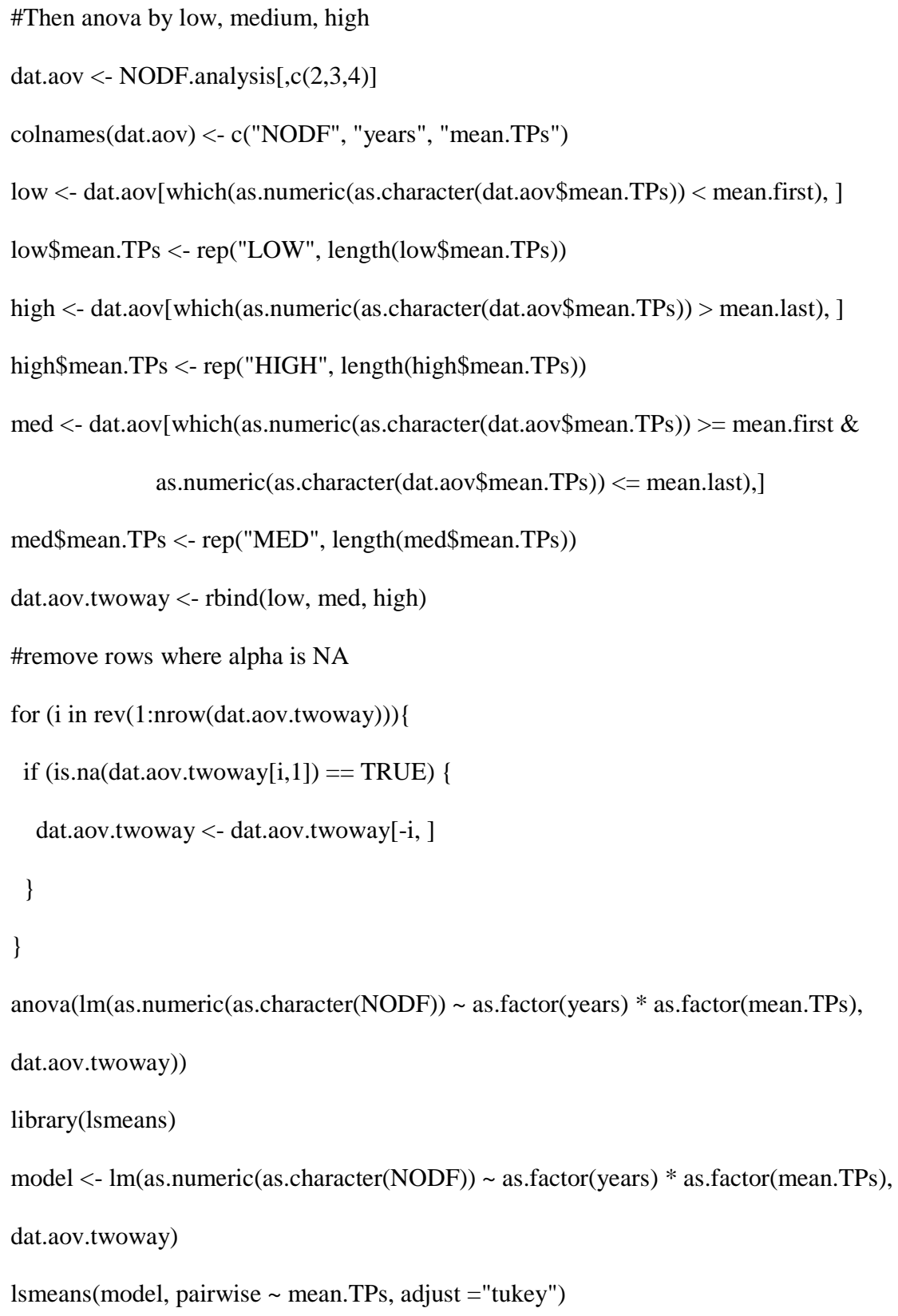




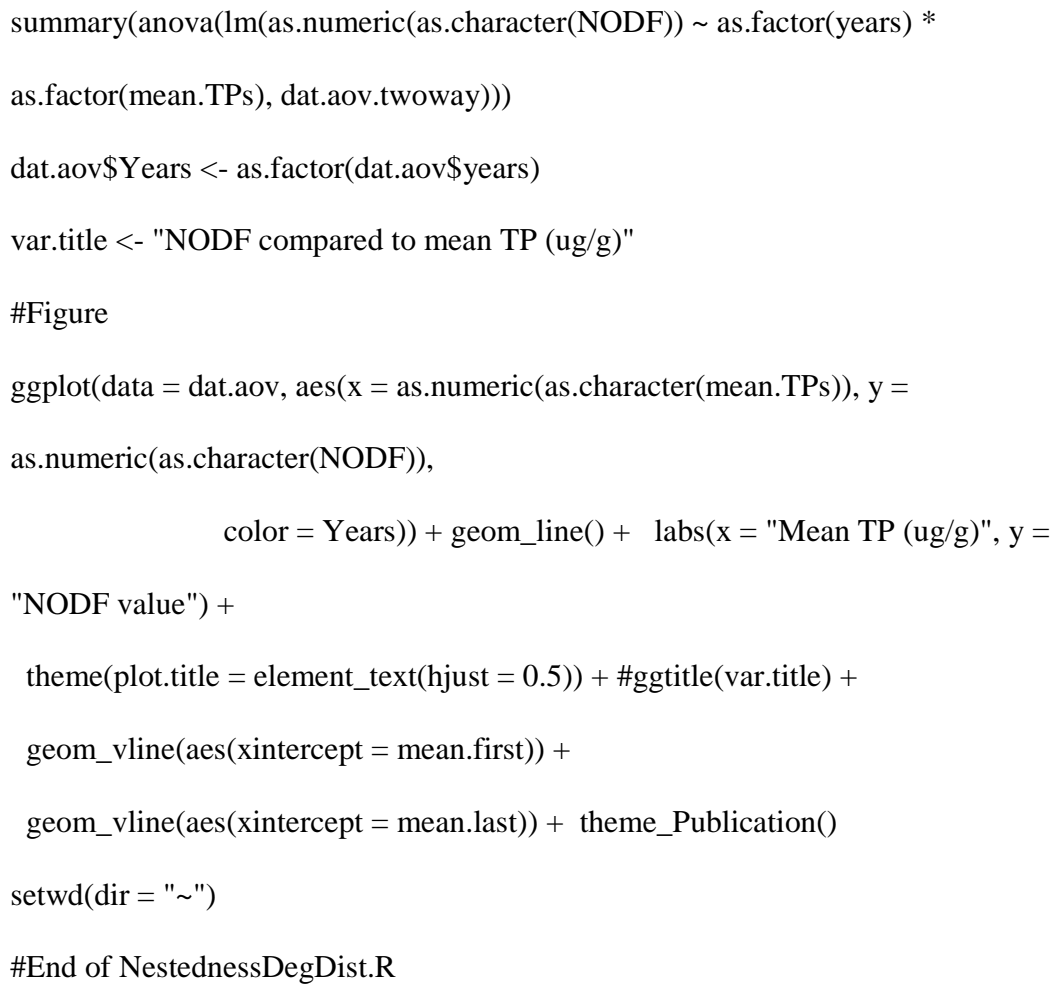

A.8 Ego Size Comparison

\#libraries

library(ggplot2)

library(igraph)

specieslist <- as.list(rep(NA, length(colnames(spp.data.raw)))

names(specieslist) <- colnames(spp.data.raw)

for (species in names(specieslist) $)\{$

output $<-\mathrm{c}()$

for (iter in 1:length(g.sim_storage $))\{$ 


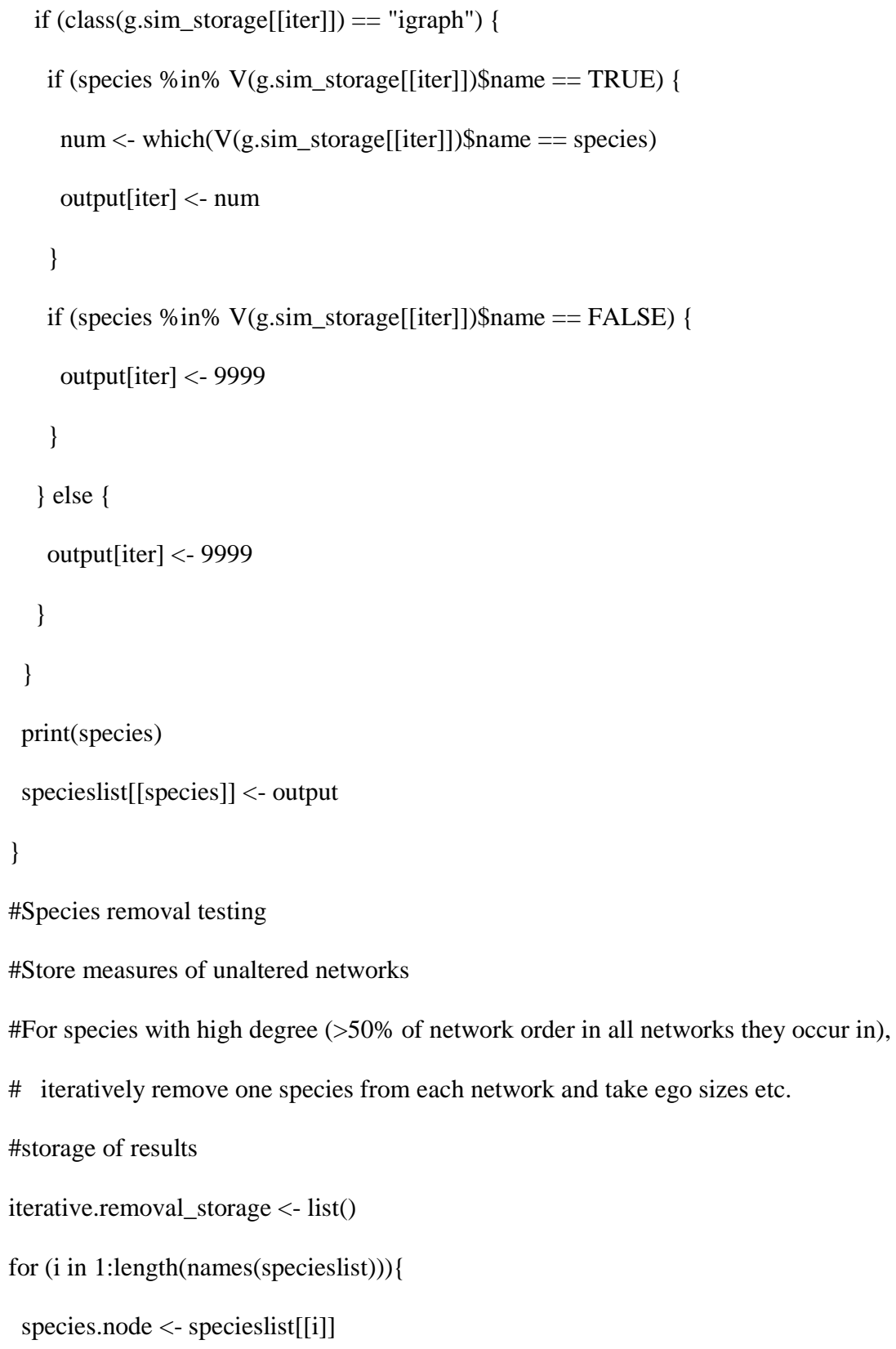




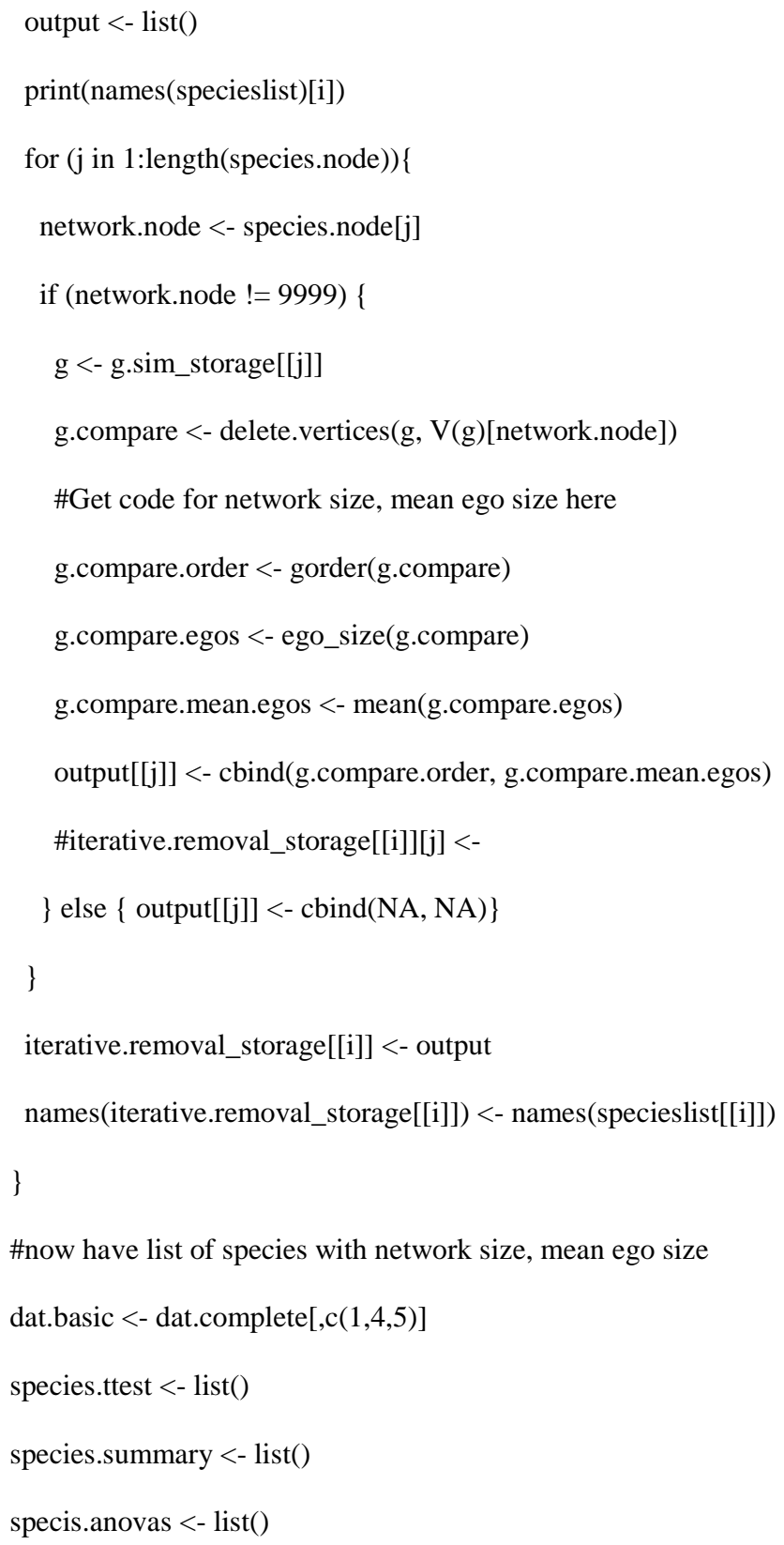




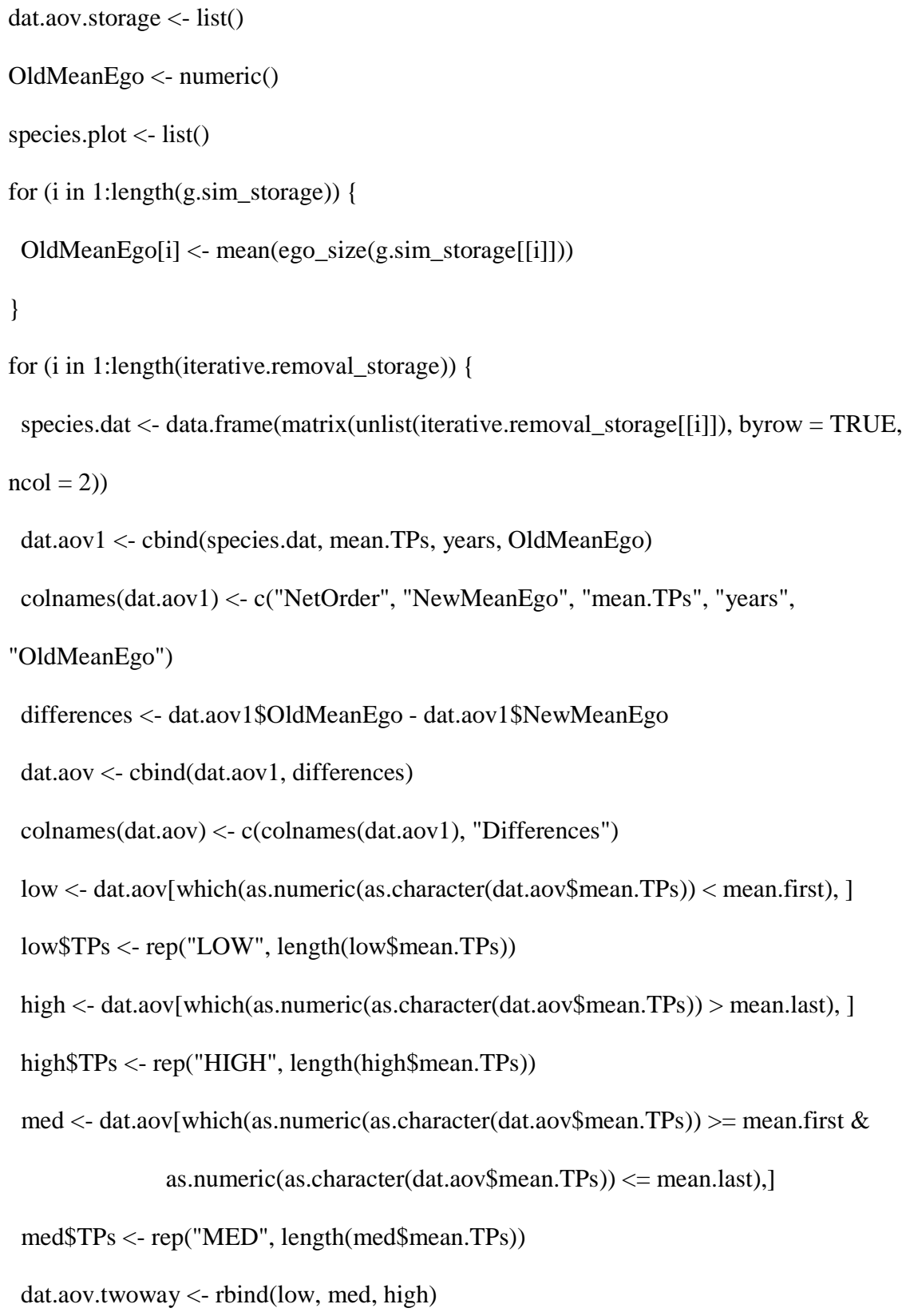




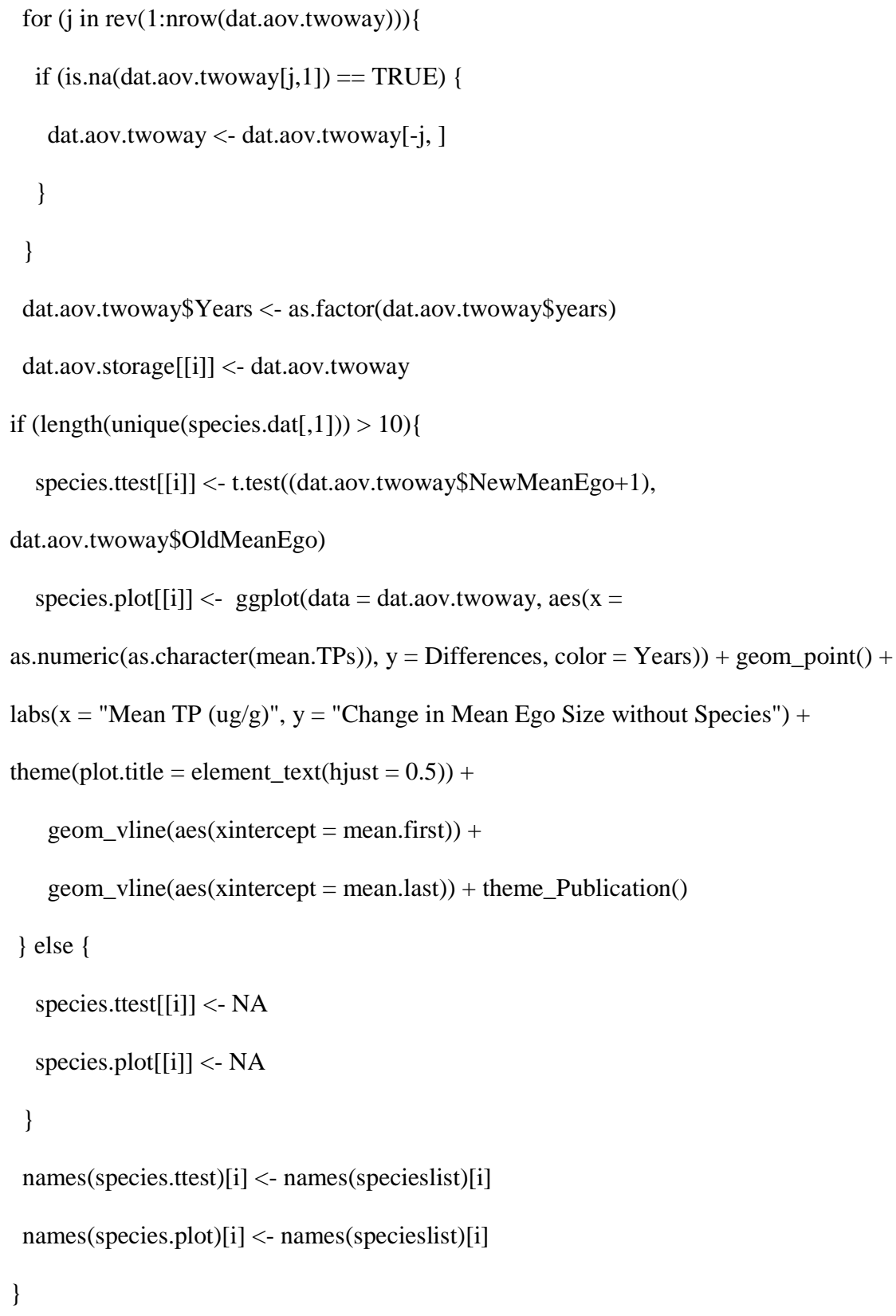




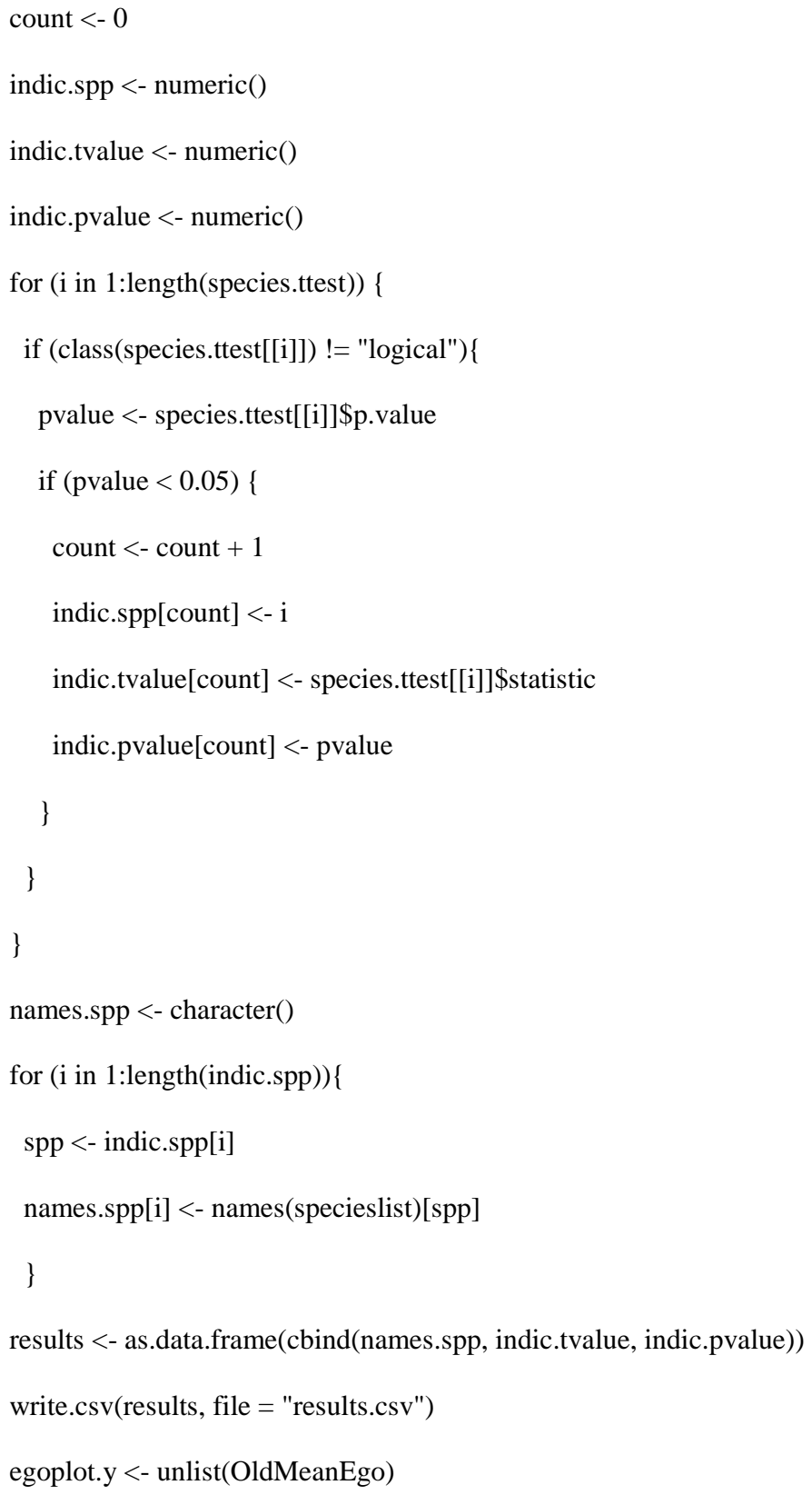




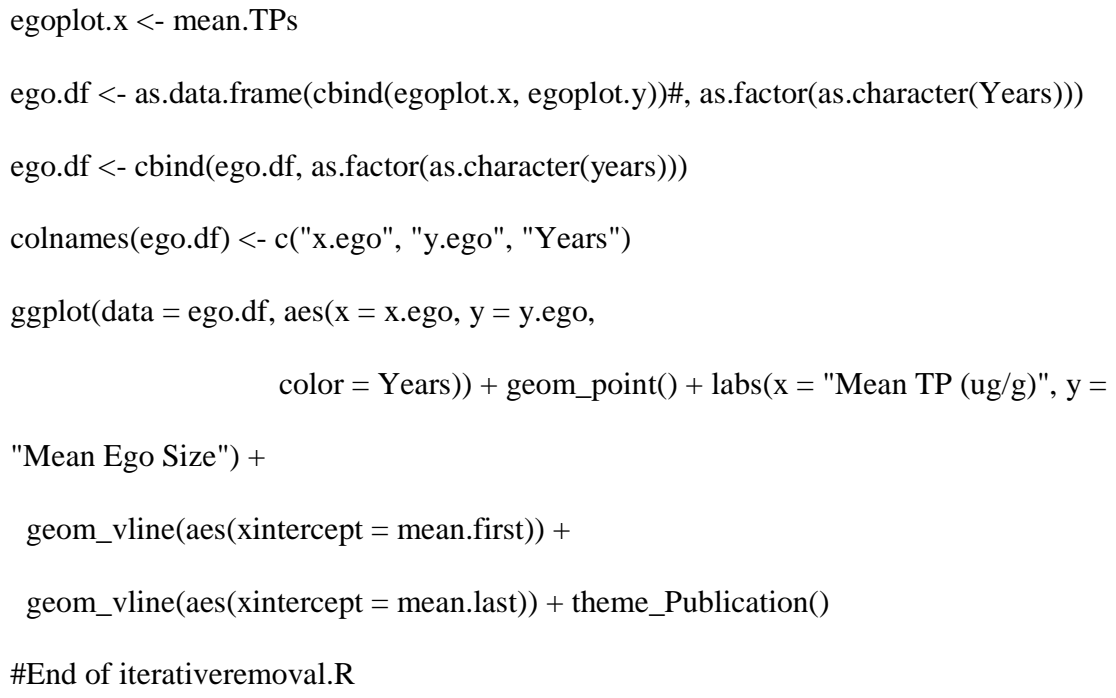

A.9 Species Frequency

\#Frequency of species

\#Overarching variables

species.frequencies $<-\operatorname{matrix}($ data $=$ NA, nrow $=$ length $($ spp.data_storage $)$, ncol $=$ ncol(spp.data_storage[[1]]))

mean.TP $<-$ numeric ()

\#Start with spp.data_storage

for (i in 1:length(spp.data_storage) $)\{$

dat <- spp.data_storage[[i]]

frequencies <- numeric()

for $(\mathrm{j}$ in $1: n \operatorname{col}(\mathrm{dat}))\{$ 


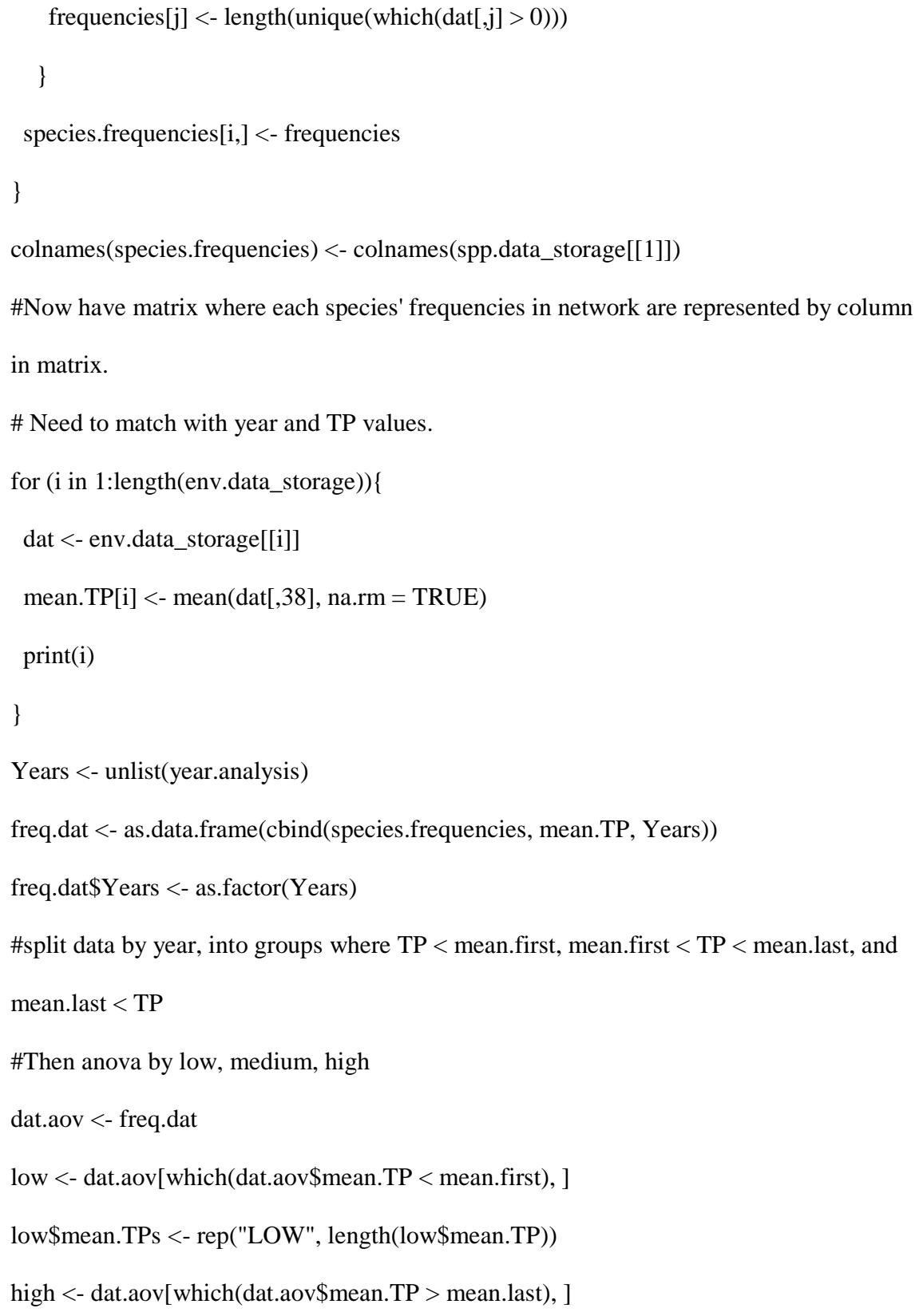




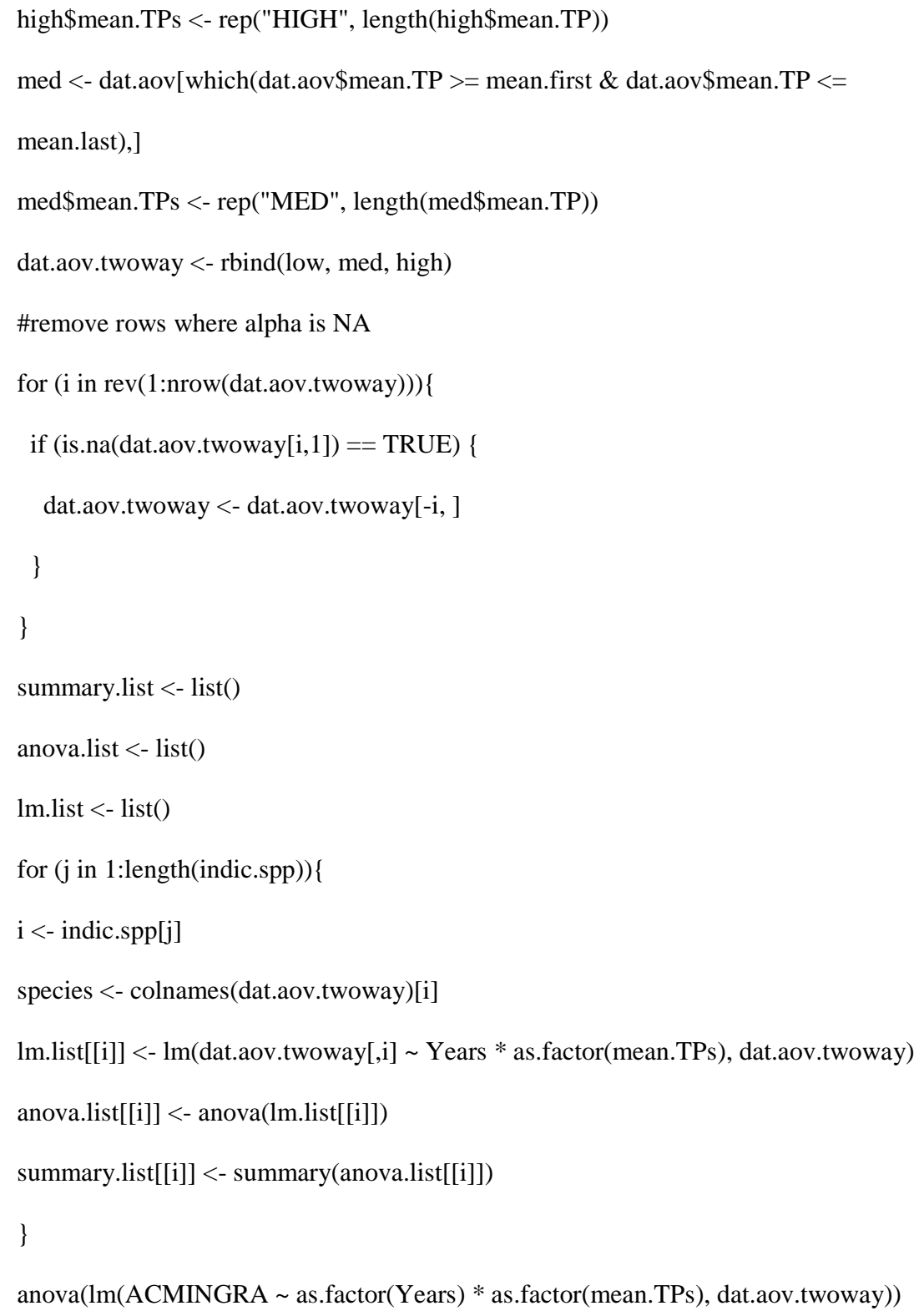




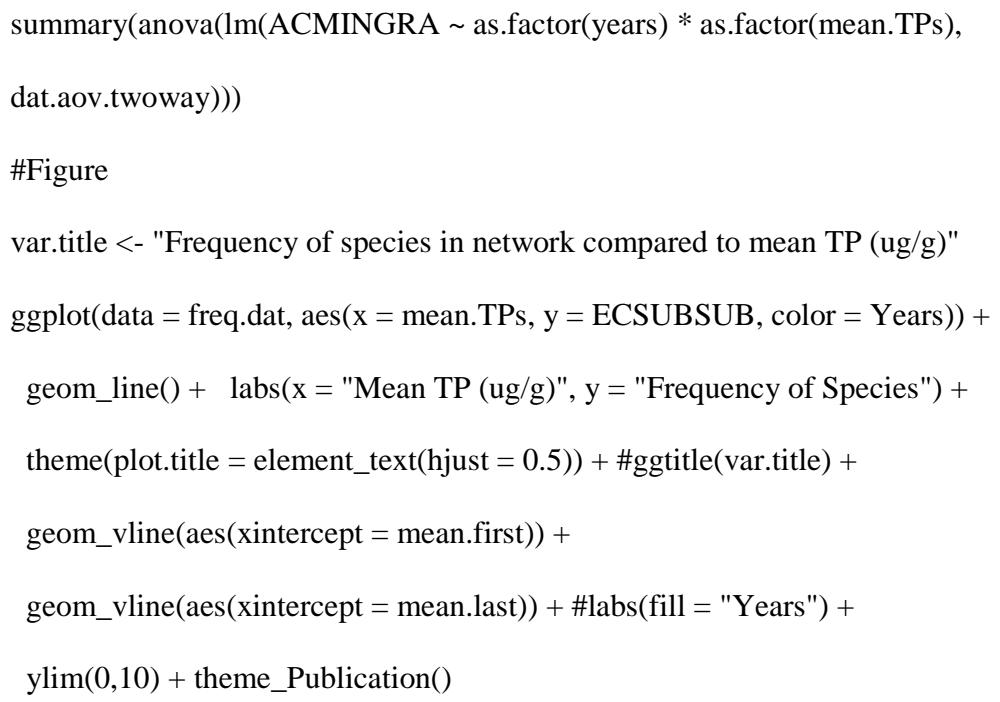


Appendix B: Species Removal Effect on Mean Ego Size - Plots and ANOVA tables

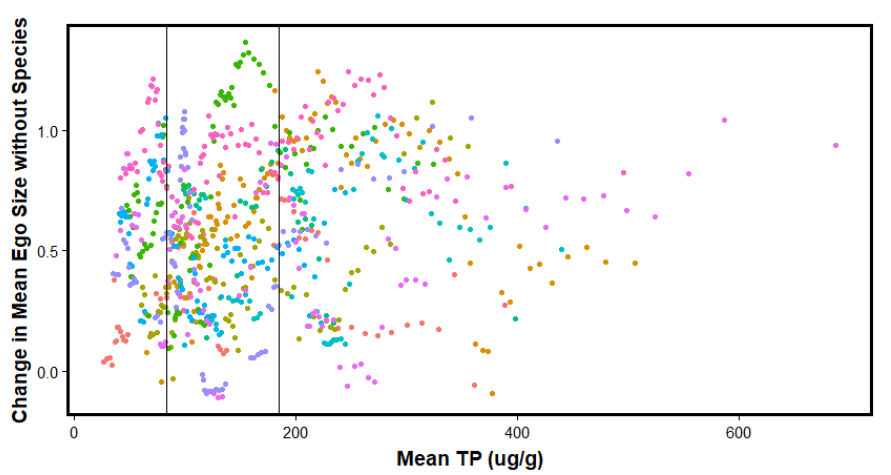

Years : ${ }_{2008}^{2007}: 2010 \div 2010 \div 2012: 2013: 2015$

Figure B1. Plot of Effect of species removal on mean ego size in network along a mean Total Phosphorus gradient $(\mu \mathrm{g} / \mathrm{g})$ for taxon Achnanthidium minutissimum var. gracillima. Vertical lines indicate thresholds at 83 and $195 \mu \mathrm{g} / \mathrm{g}$. Two-way ANOVA with replication follows immediately.

Analysis of Variance Table

Response: Differences

\begin{tabular}{|l|l|l|l|l|l|}
\hline & Df & Sum Sq & Mean Sq & F value & $\operatorname{Pr}(>\mathrm{F})$ \\
\hline Year & 9 & 22.675 & 2.51946 & 37.2529 & $<2.2 \mathrm{e}-16 * * *$ \\
\hline TP & 2 & 2.283 & 1.14154 & 16.8789 & $6.751 \mathrm{e}-08 * * *$ \\
\hline Year:TP & 16 & 5.577 & 0.34855 & 5.1536 & $2.557 \mathrm{e}-10 * * *$ \\
\hline Residuals & 752 & 50.859 & 0.06763 & & \\
\hline
\end{tabular}

Signif. codes: 0 ‘***’ 0.001 '**’ 0.01 '*’ 0.05 '? 0.1 ' ’ 1 


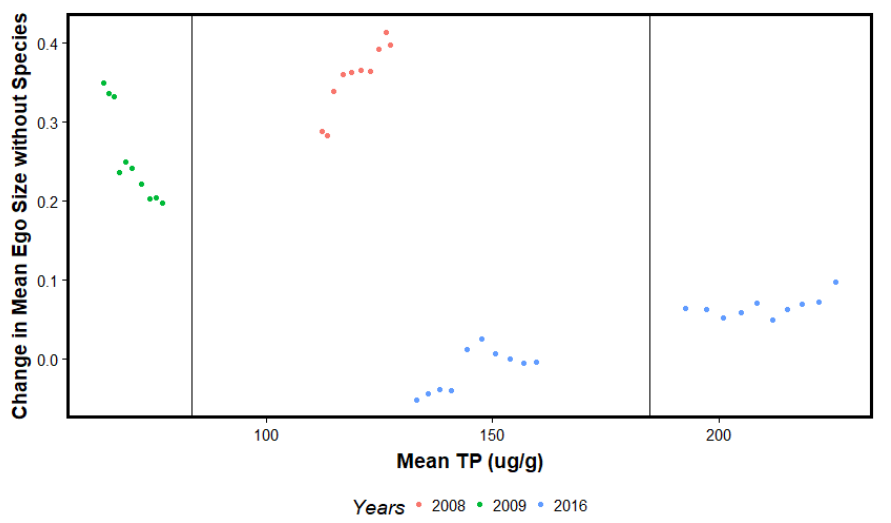

Figure B2. Plot of Effect of species removal on mean ego size in network along a mean Total Phosphorus gradient $(\mu \mathrm{g} / \mathrm{g})$ for taxon Amphora ovalis. Vertical lines indicate thresholds at 83 and $195 \mu \mathrm{g} / \mathrm{g}$. Two-way ANOVA with replication follows immediately.

Analysis of Variance Table

\section{Response: Differences}

\begin{tabular}{|l|l|l|l|l|l|}
\hline & Df & Sum Sq & Mean Sq & F value & $\operatorname{Pr}(>\mathrm{F})$ \\
\hline Year & 2 & 0.83874 & 0.41937 & 265.857 & $<2.2 \mathrm{e}-16 * * *$ \\
\hline TP & 1 & 0.03191 & 0.03191 & 20.232 & $6.888 \mathrm{e}-05 * * *$ \\
\hline Residuals & 36 & 0.05679 & 0.00158 & & \\
\hline
\end{tabular}

$---$

Signif. codes: 0 “***’ 0.001 '**’ 0.01 '*’ 0.05 '? 0.1 ', 1 


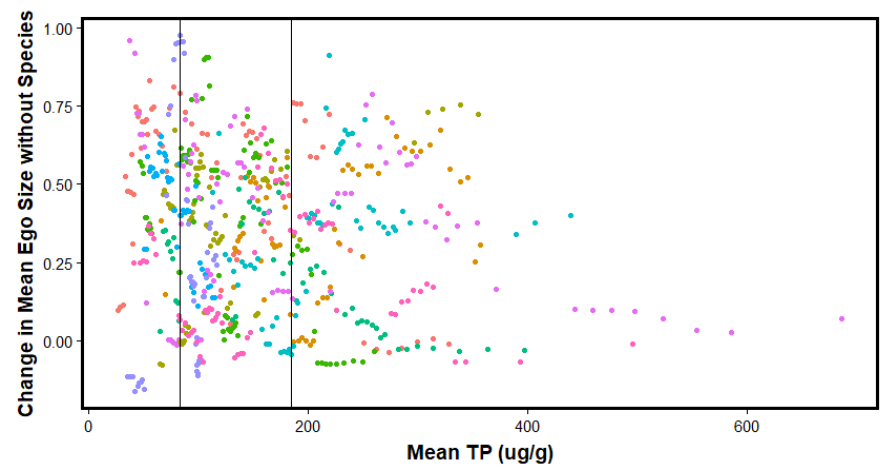

Years $: 2007: 2009: 2010: 2011: 2013: 2014: 2015$

Figure B3. Plot of Effect of species removal on mean ego size in network along a mean Total Phosphorus gradient $(\mu \mathrm{g} / \mathrm{g}$ ) for taxon Amphora sulcata. Vertical lines indicate thresholds at 83 and $195 \mu \mathrm{g} / \mathrm{g}$. Two-way ANOVA with replication follows immediately.

Analysis of Variance Table

Response: Differences

\begin{tabular}{|l|l|l|l|l|l|}
\hline & Df & Sum Sq & Mean Sq & F value & $\operatorname{Pr}(>\mathrm{F})$ \\
\hline Year & 9 & 5.1711 & 0.57457 & 11.0970 & $4.559 \mathrm{e}-16 * * *$ \\
\hline TP & 2 & 0.5053 & 0.25265 & 4.8795 & $0.007913 * *$ \\
\hline Year:TP & 15 & 5.0936 & 0.33958 & 6.5584 & $4.335 \mathrm{e}-13 * * *$ \\
\hline Residuals & 585 & 30.2897 & 0.05178 & & \\
\hline
\end{tabular}

Signif. codes: 0 ‘***’ 0.001 '**’ 0.01 '*’ 0.05 '? 0.1 ' ' 1 


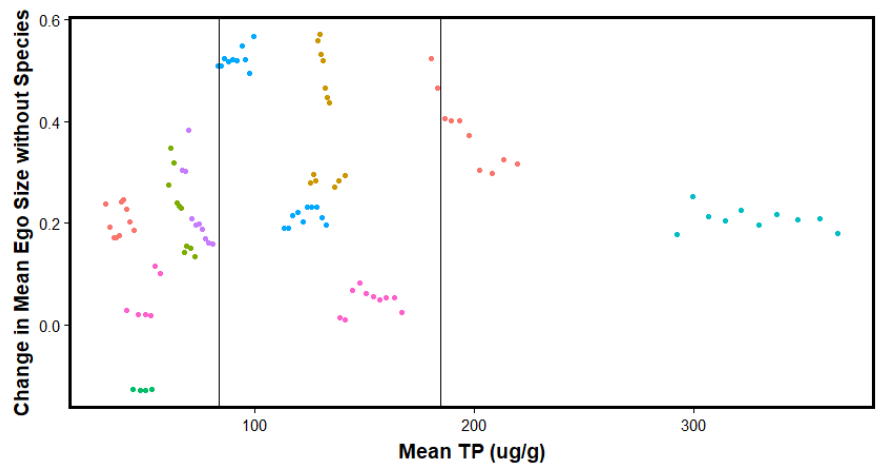

Years $: 2007: 2009: 2011: 2013: 2015$

Figure B4. Plot of Effect of species removal on mean ego size in network along a mean Total Phosphorus gradient $(\mu \mathrm{g} / \mathrm{g})$ for taxon Aulacoseira cf. distans. Vertical lines indicate thresholds at 83 and $195 \mu \mathrm{g} / \mathrm{g}$. Two-way ANOVA with replication follows immediately.

Analysis of Variance Table

Response: Differences

\begin{tabular}{|l|l|l|l|l|l|}
\hline & Df & Sum Sq & Mean Sq & F value & $\operatorname{Pr}(>\mathrm{F})$ \\
\hline Year & 7 & 1.86844 & 0.266921 & 30.6340 & $<2.2 \mathrm{e}-16^{* * *}$ \\
\hline TP & 2 & 0.06473 & 0.032363 & 3.7142 & $0.0281447 *$ \\
\hline Year:TP & 2 & 0.14369 & 0.071845 & 8.2456 & $0.0005116^{* * *}$ \\
\hline Residuals & 91 & 0.79290 & 0.008713 & & \\
\hline
\end{tabular}

Signif. codes: 0 ‘***’ 0.001 ‘** 0.01 '*’ 0.05 '? 0.1 ', 1 


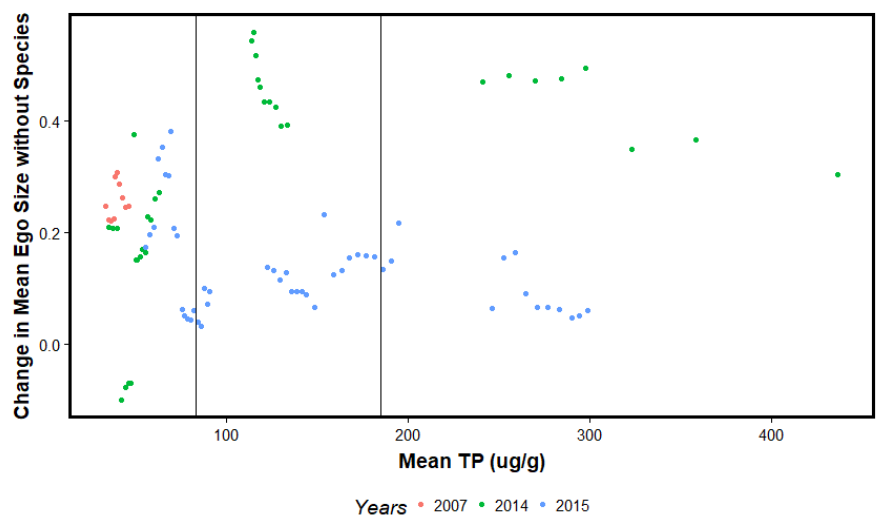

Figure B5. Plot of Effect of species removal on mean ego size in network along a mean Total Phosphorus gradient $(\mu \mathrm{g} / \mathrm{g})$ for taxon Aulacoseira cf. granulata. Vertical lines indicate thresholds at 83 and $195 \mu \mathrm{g} / \mathrm{g}$. Two-way ANOVA with replication follows immediately.

Analysis of Variance Table

\section{Response: Differences}

\begin{tabular}{|l|l|l|l|l|l|}
\hline & Df & Sum Sq & Mean Sq & F value & $\operatorname{Pr}(>\mathrm{F})$ \\
\hline Year & 2 & 0.57288 & 0.28644 & 37.190 & $2.127 \mathrm{e}-12 * * *$ \\
\hline TP & 2 & 0.16257 & 0.08129 & 10.554 & $7.878 \mathrm{e}-05 * * *$ \\
\hline Year:TP & 2 & 0.71382 & 0.35691 & 46.339 & $1.989 \mathrm{e}-14 * * *$ \\
\hline Residuals & 87 & 0.67009 & 0.00770 & & \\
\hline
\end{tabular}

Signif. codes: 0 ‘***’ 0.001 '**’ 0.01 '*’ 0.05 '? 0.1 ' ' 1 


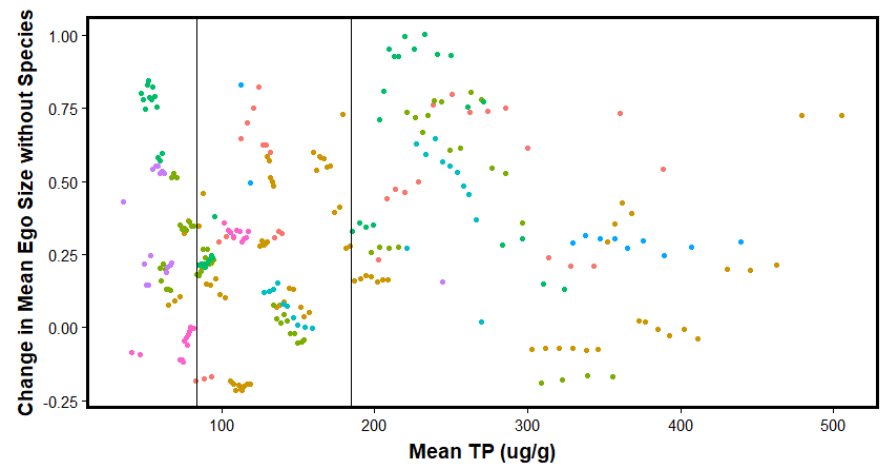

Years : $2007: 2009: 2010: 2011: 2013$

Figure B6. Plot of Effect of species removal on mean ego size in network along a mean Total Phosphorus gradient $(\mu \mathrm{g} / \mathrm{g})$ for taxon Brachysira brebissonii. Vertical lines indicate thresholds at 83 and $195 \mu \mathrm{g} / \mathrm{g}$. Two-way ANOVA with replication follows immediately.

Analysis of Variance Table

Response: Differences

\begin{tabular}{|l|l|l|l|l|l|}
\hline & Df & Sum Sq & Mean Sq & F value & $\operatorname{Pr}(>\mathrm{F})$ \\
\hline Year & 7 & 5.8333 & 0.83332 & 16.7018 & $<2.2 \mathrm{e}-16 * * *$ \\
\hline TP & 2 & 0.6152 & 0.30759 & 6.1649 & $0.002417 * *$ \\
\hline Year:TP & 10 & 4.5138 & 0.45138 & 9.0468 & $8.106 \mathrm{e}-13 * * *$ \\
\hline Residuals & 264 & 13.1721 & 0.04989 & & \\
\hline
\end{tabular}

Signif. codes: 0 ‘***’ 0.001 '**’ 0.01 '*’ 0.05 '? 0.1 ' ' 1 


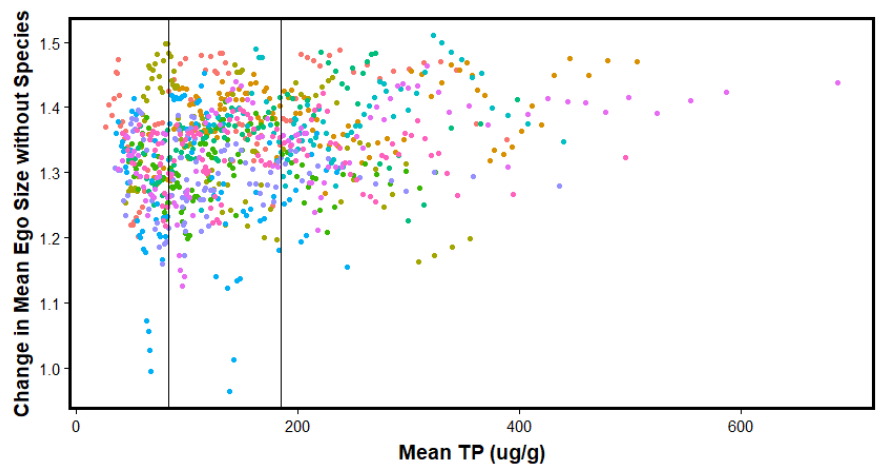

Years $: 2007: 2009: 2010: 2012: 2013: 2015$

Figure B7. Plot of Effect of species removal on mean ego size in network along a mean Total Phosphorus gradient $(\mu \mathrm{g} / \mathrm{g})$ for taxon Brachysira microcephala. Vertical lines indicate thresholds at 83 and $195 \mu \mathrm{g} / \mathrm{g}$. Two-way ANOVA with replication follows immediately.

Analysis of Variance Table

Response: Differences

\begin{tabular}{|l|l|l|l|l|l|}
\hline & Df & Sum Sq & Mean Sq & F value & $\operatorname{Pr}(>\mathrm{F})$ \\
\hline Year & 9 & 1.2714 & 0.141263 & 34.0459 & $<2.2 \mathrm{e}-16 * * *$ \\
\hline TP & 2 & 0.1001 & 0.050060 & 12.0650 & $6.763 \mathrm{e}-06 * * *$ \\
\hline Year:TP & 17 & 0.3334 & 0.019611 & 4.7265 & $1.035 \mathrm{e}-09 * * *$ \\
\hline Residuals & 888 & 3.6845 & 0.004149 & & \\
\hline
\end{tabular}

Signif. codes: 0 ‘***’ 0.001 '**’ 0.01 '*’ 0.05 '? 0.1 ' ' 1 


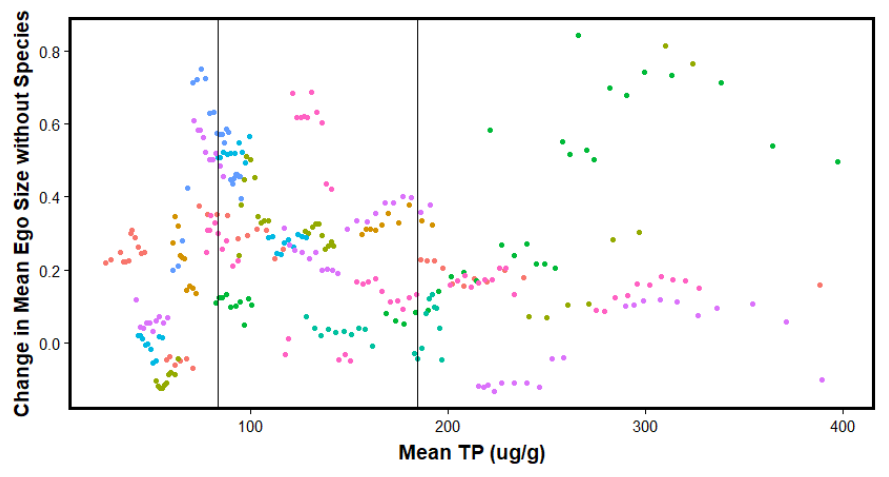

Years : $2007: 2009: 2011: 2012: 2014 \cdot 2016$

Figure B8. Plot of Effect of species removal on mean ego size in network along a mean Total Phosphorus gradient $(\mu \mathrm{g} / \mathrm{g})$ for taxon Caponea caribbea. Vertical lines indicate thresholds at 83 and $195 \mu \mathrm{g} / \mathrm{g}$. Twoway ANOVA with replication follows immediately.

Analysis of Variance Table

Response: Differences

\begin{tabular}{|l|l|l|l|l|l|}
\hline & Df & Sum Sq & Mean Sq & F value & $\operatorname{Pr}(>\mathrm{F})$ \\
\hline Year & 8 & 3.0010 & 0.37513 & 15.572 & $<2.2 \mathrm{e}-16 * * *$ \\
\hline TP & 2 & 0.6295 & 0.31473 & 13.065 & $3.627 \mathrm{e}-06 * * *$ \\
\hline Year:TP & 13 & 3.9996 & 0.30766 & 12.771 & $<2.2 \mathrm{e}-16 * * *$ \\
\hline Residuals & 300 & 7.2269 & 0.02409 & & \\
\hline
\end{tabular}

Signif. codes: 0 ‘***’ 0.001 '**’ 0.01 '*’ 0.05 '? 0.1 ' ' 1 


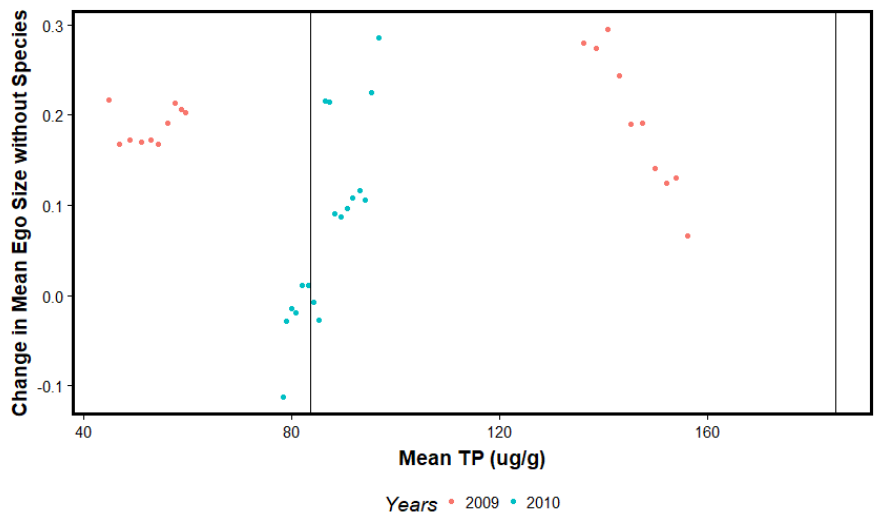

Figure B9. Plot of Effect of species removal on mean ego size in network along a mean Total Phosphorus gradient $(\mu \mathrm{g} / \mathrm{g}$ ) for taxon Craticula accomodiformis. Vertical lines indicate thresholds at 83 and $195 \mu \mathrm{g} / \mathrm{g}$. Two-way ANOVA with replication follows immediately.

Analysis of Variance Table

Response: Differences

\begin{tabular}{|l|l|l|l|l|l|}
\hline & Df & Sum Sq & Mean Sq & F value & $\operatorname{Pr}(>\mathrm{F})$ \\
\hline Year & 1 & 0.125967 & 0.125967 & 25.8751 & $1.326 \mathrm{e}-05 * * *$ \\
\hline TP & 1 & 0.044461 & 0.044461 & 9.1327 & $0.004746 * *$ \\
\hline Year:TP & 1 & 0.046997 & 0.046997 & 9.6537 & $0.003802 * *$ \\
\hline Residuals & 34 & 0.165521 & 0.004868 & & \\
\hline
\end{tabular}

Signif. codes: 0 ‘***’ 0.001 '**’ 0.01 '*’ 0.05 '? 0.1 ' ' 1 


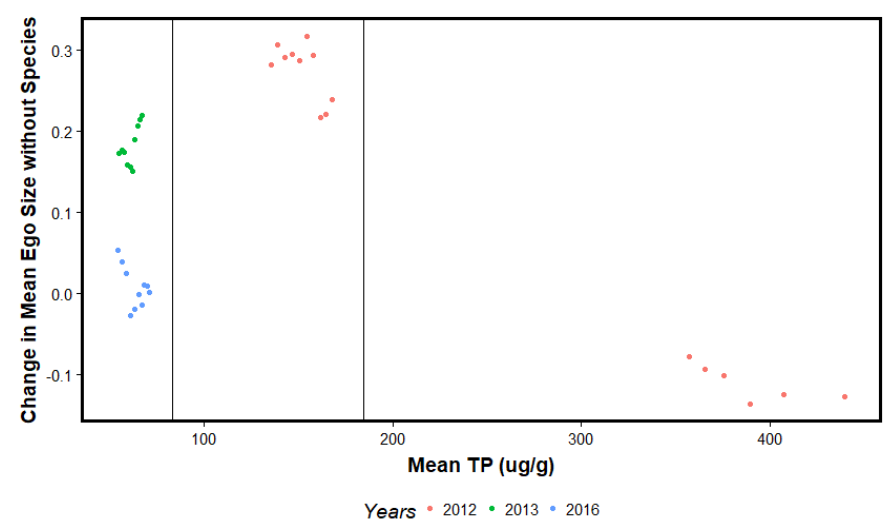

Figure B10. Plot of Effect of species removal on mean ego size in network along a mean Total Phosphorus gradient $(\mu \mathrm{g} / \mathrm{g})$ for taxon Cyclotella iris. Vertical lines indicate thresholds at 83 and $195 \mu \mathrm{g} / \mathrm{g}$. Two-way ANOVA with replication follows immediately.

Analysis of Variance Table

Response: Differences

\begin{tabular}{|l|l|l|l|l|l|}
\hline & Df & Sum Sq & Mean Sq & F value & $\operatorname{Pr}(>\mathrm{F})$ \\
\hline Year & 2 & 0.16291 & 0.08145 & 102.24 & $1.265 \mathrm{e}-14 * * *$ \\
\hline TP & 1 & 0.55396 & 0.55396 & 695.30 & $<2.2 \mathrm{e}-16 * * *$ \\
\hline Residuals & 32 & 0.02550 & 0.00080 & & \\
\hline
\end{tabular}

Signif. codes: 0 “***’ 0.001 '**, 0.01 '*’ 0.05 '? 0.1 ' ' 1 


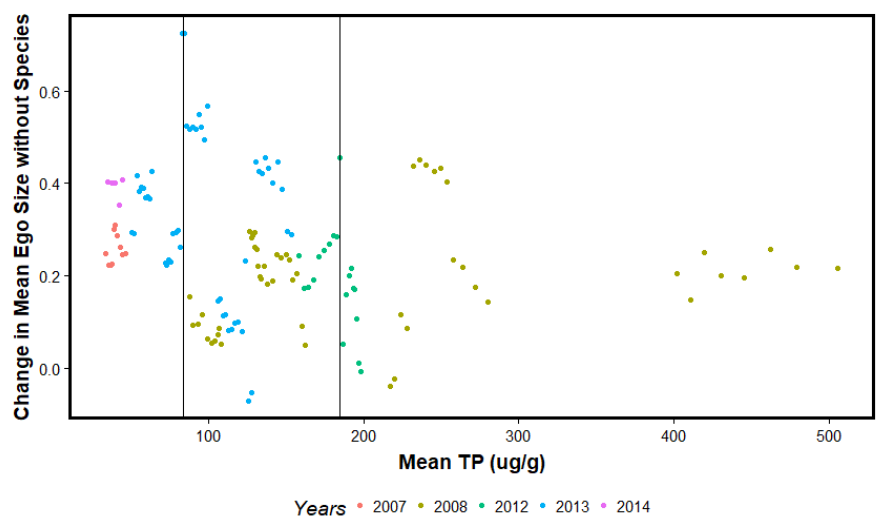

Figure B11. Plot of Effect of species removal on mean ego size in network along a mean Total Phosphorus gradient $(\mu \mathrm{g} / \mathrm{g})$ for taxon Diploneis puella. Vertical lines indicate thresholds at 83 and $195 \mu \mathrm{g} / \mathrm{g}$. Two-way ANOVA with replication follows immediately.

Analysis of Variance Table

Response: Differences

\begin{tabular}{|l|l|l|l|l|l|}
\hline & Df & Sum Sq & Mean Sq & F value & $\operatorname{Pr}(>\mathrm{F})$ \\
\hline Year & 4 & 0.60641 & 0.151603 & 8.3398 & $5.199 \mathrm{e}-06 * * *$ \\
\hline TP & 2 & 0.00501 & 0.002503 & 0.1377 & 0.871499 \\
\hline Year:TP & 1 & 0.13588 & 0.135875 & 7.4746 & $0.007144 * *$ \\
\hline Residuals & 128 & 2.32682 & 0.018178 & & \\
\hline
\end{tabular}

Signif. codes: 0 ‘***’ 0.001 '**’ 0.01 '*’ 0.05 '? 0.1 ' ' 1 


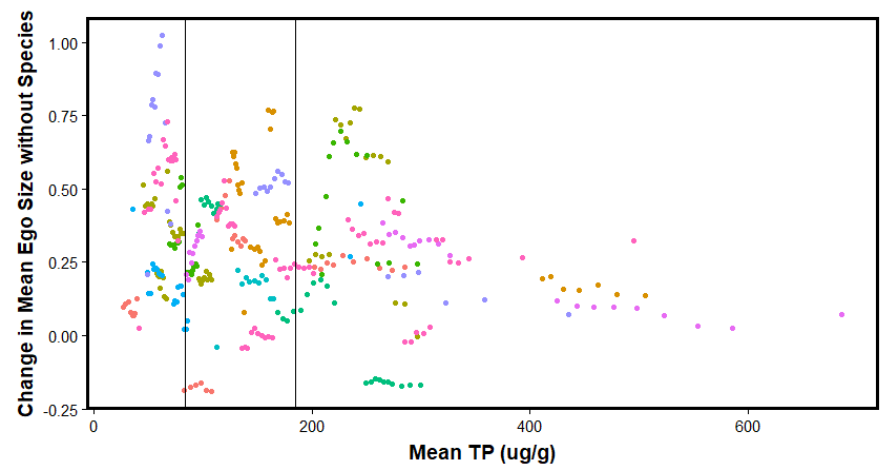

Years : $2007: 2008: 2010: 2011: 2013: 2015$

Figure B12. Plot of Effect of species removal on mean ego size in network along a mean Total Phosphorus gradient $(\mu \mathrm{g} / \mathrm{g})$ for taxon Ensyonopsis egsp01. Vertical lines indicate thresholds at 83 and $195 \mu \mathrm{g} / \mathrm{g}$. Twoway ANOVA with replication follows immediately.

Analysis of Variance Table

Response: Differences

\begin{tabular}{|l|l|l|l|l|l|}
\hline & Df & Sum Sq & Mean Sq & F value & $\operatorname{Pr}(>\mathrm{F})$ \\
\hline Year & 9 & 4.2143 & 0.46825 & 18.837 & $<2.2 \mathrm{e}-16 * * *$ \\
\hline TP & 2 & 0.5015 & 0.25075 & 10.087 & $5.626 \mathrm{e}-05 * * *$ \\
\hline Year:TP & 13 & 4.5968 & 0.35360 & 14.225 & $<2.2 \mathrm{e}-16 * * *$ \\
\hline Residuals & 324 & 8.0541 & 0.02486 & & \\
\hline
\end{tabular}

Signif. codes: 0 ‘***’ 0.001 '**’ 0.01 '*’ 0.05 '? 0.1 ' ' 1 


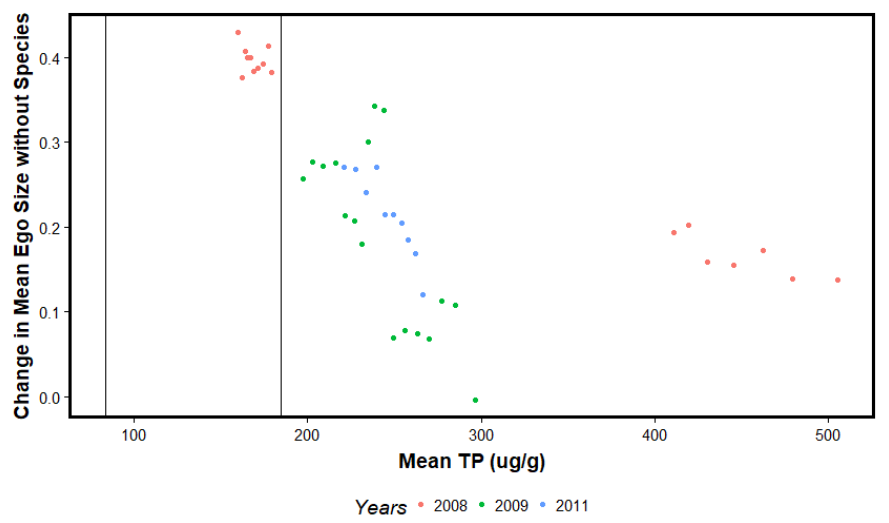

Figure B13. Plot of Effect of species removal on mean ego size in network along a mean Total Phosphorus gradient $(\mu \mathrm{g} / \mathrm{g})$ for taxon Encyonopsis floridiana. Vertical lines indicate thresholds at 83 and $195 \mu \mathrm{g} / \mathrm{g}$. Two-way ANOVA with replication follows immediately.

Analysis of Variance Table

\section{Response: Differences}

\begin{tabular}{|l|l|l|l|l|l|}
\hline & Df & Sum Sq & Mean Sq & F value & $\operatorname{Pr}(>\mathrm{F})$ \\
\hline Year & 2 & 0.11929 & 0.059647 & 10.967 & $0.0001595 * * *$ \\
\hline TP & 1 & 0.22198 & 0.221975 & 40.812 & $1.345 \mathrm{e}-07 * * *$ \\
\hline Residuals & 40 & 0.21756 & 0.005439 & & \\
\hline
\end{tabular}

Signif. codes: 0 “***’ 0.001 '**, 0.01 '*’ 0.05 '. 0.1 ' ' 1 


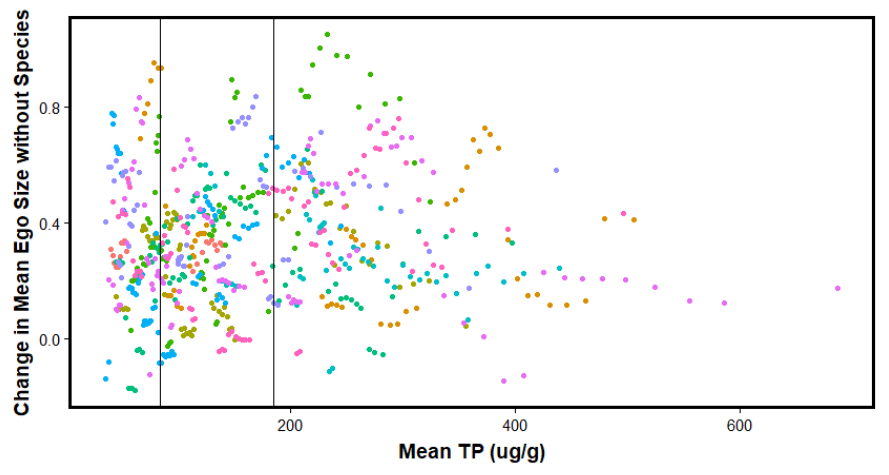

Years $: 2007: 2009: 2011: 2013: 2015$

Figure B14. Plot of Effect of species removal on mean ego size in network along a mean Total Phosphorus gradient $(\mu \mathrm{g} / \mathrm{g}$ ) for taxon Encyonopsis subminuta. Vertical lines indicate thresholds at 83 and $195 \mu \mathrm{g} / \mathrm{g}$. Two-way ANOVA with replication follows immediately.

Analysis of Variance Table

Response: Differences

\begin{tabular}{|l|l|l|l|l|l|}
\hline & Df & Sum Sq & Mean Sq & F value & $\operatorname{Pr}(>\mathrm{F})$ \\
\hline Year & 9 & 2.5701 & 0.28557 & 7.2352 & $4.972 \mathrm{e}-10 * * *$ \\
\hline TP & 2 & 0.8683 & 0.43413 & 10.9991 & $2.028 \mathrm{e}-05 * * *$ \\
\hline Year:TP & 16 & 6.2330 & 0.38956 & 9.8700 & $<2.2 \mathrm{e}-16 * * *$ \\
\hline Residuals & 612 & 24.1554 & 0.03947 & & \\
\hline
\end{tabular}

Signif. codes: 0 ‘***’ 0.001 '**’ 0.01 '*’ 0.05 '? 0.1 ' ' 1 


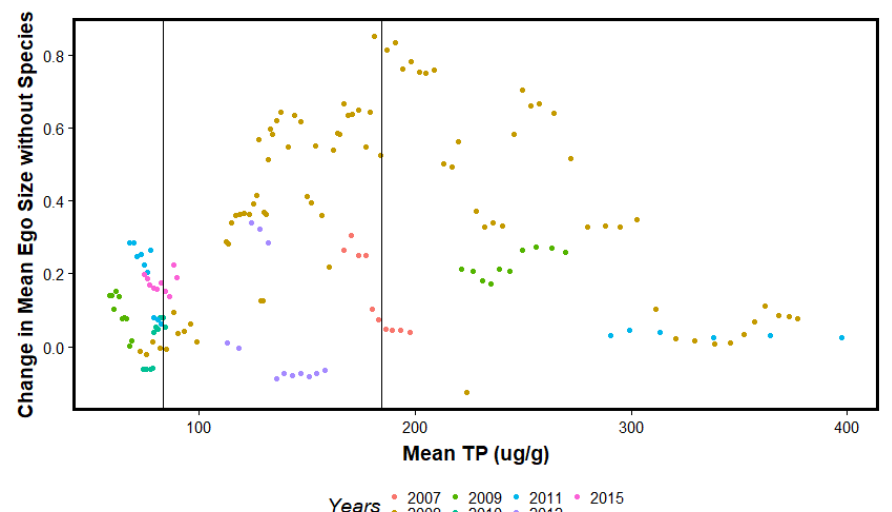

Figure B15. Plot of Effect of species removal on mean ego size in network along a mean Total Phosphorus gradient $(\mu \mathrm{g} / \mathrm{g})$ for taxon Encyonema cf. evergladianum. Vertical lines indicate thresholds at 83 and 195 $\mu \mathrm{g} / \mathrm{g}$. Two-way ANOVA with replication follows immediately.

Analysis of Variance Table

Response: Differences

\begin{tabular}{|l|l|l|l|l|l|}
\hline & Df & Sum Sq & Mean Sq & F value & $\operatorname{Pr}(>\mathrm{F})$ \\
\hline Year & 6 & 3.2245 & 0.53742 & 14.4280 & $6.431 \mathrm{e}-13 * * *$ \\
\hline TP & 2 & 0.2506 & 0.12528 & 3.3634 & $0.037285 *$ \\
\hline Year:TP & 5 & 0.6739 & 0.13479 & 3.6186 & $0.004066 * *$ \\
\hline Residuals & 148 & 5.5128 & 0.03725 & & \\
\hline
\end{tabular}

Signif. codes: 0 ‘***’ 0.001 '**’ 0.01 '*’ 0.05 '? 0.1 ' ' 1 


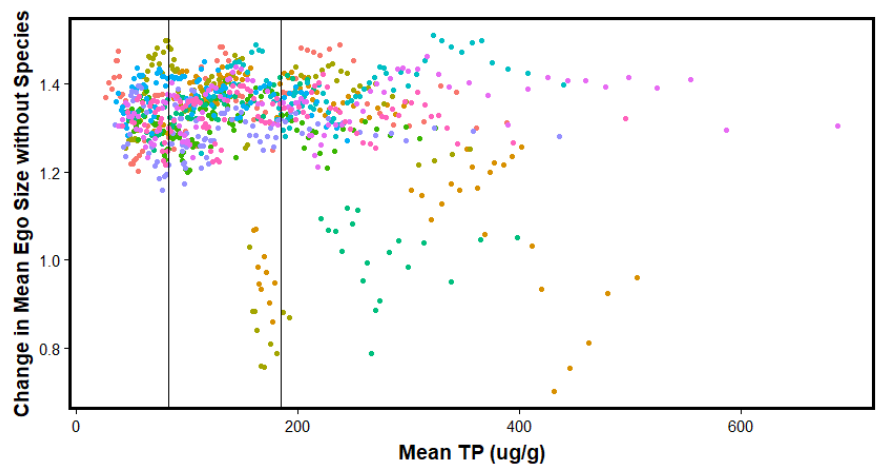

Years $: 2007: 2009: 2011: 2013: 2015$

Figure B16. Plot of Effect of species removal on mean ego size in network along a mean Total Phosphorus gradient $(\mu \mathrm{g} / \mathrm{g})$ for taxon Encyonema evergladianum. Vertical lines indicate thresholds at 83 and $195 \mu \mathrm{g} / \mathrm{g}$. Two-way ANOVA with replication follows immediately.

Analysis of Variance Table

Response: Differences

\begin{tabular}{|l|l|l|l|l|l|}
\hline & Df & Sum Sq & Mean Sq & F value & $\operatorname{Pr}(>\mathrm{F})$ \\
\hline Year & 9 & 1.3251 & 0.147232 & 15.2633 & $<2.2 \mathrm{e}-16 * * *$ \\
\hline TP & 2 & 0.1781 & 0.089064 & 9.2332 & $0.0001075 * * *$ \\
\hline Year:TP & 17 & 1.2524 & 0.073668 & 7.6371 & $<2.2 \mathrm{e}-16 * * *$ \\
\hline Residuals & 888 & 8.5658 & 0.009646 & & \\
\hline
\end{tabular}

Signif. codes: 0 ‘***’ 0.001 '**’ 0.01 '*’ 0.05 '? 0.1 ' ’ 1 


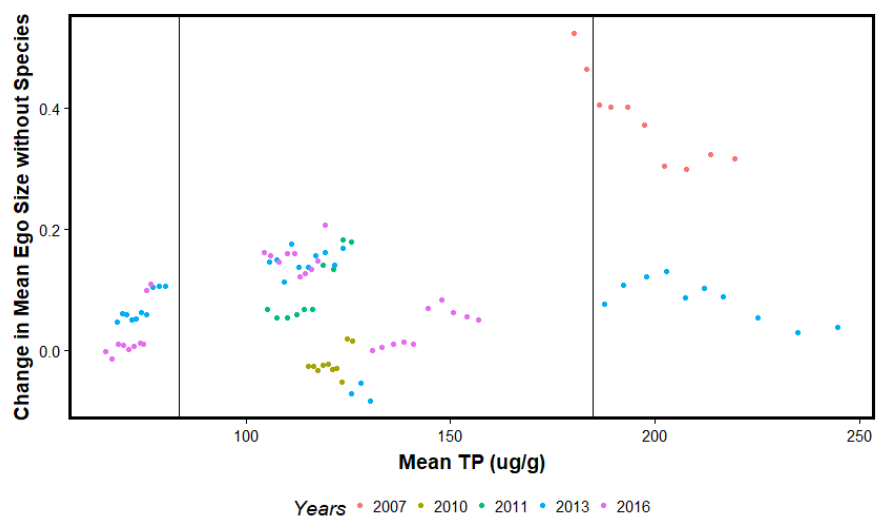

Figure B17. Plot of Effect of species removal on mean ego size in network along a mean Total Phosphorus gradient $(\mu \mathrm{g} / \mathrm{g})$ for taxon Encyonema ftsp04. Vertical lines indicate thresholds at 83 and $195 \mu \mathrm{g} / \mathrm{g}$. Twoway ANOVA with replication follows immediately.

Analysis of Variance Table

Response: Differences

\begin{tabular}{|l|l|l|l|l|l|}
\hline & Df & Sum Sq & Mean Sq & F value & $\operatorname{Pr}(>\mathrm{F})$ \\
\hline Year & 4 & 0.97145 & 0.242862 & 74.8108 & $<2.2 \mathrm{e}-16 * * *$ \\
\hline TP & 2 & 0.04588 & 0.022941 & 7.0668 & $0.001457 * *$ \\
\hline Year:TP & 2 & 0.02274 & 0.011369 & 3.5022 & $0.034602 *$ \\
\hline Residuals & 84 & 0.27269 & 0.003246 & & \\
\hline
\end{tabular}

Signif. codes: 0 ‘***’ 0.001 '**’ 0.01 '*’ 0.05 '? 0.1 ' ' 1 


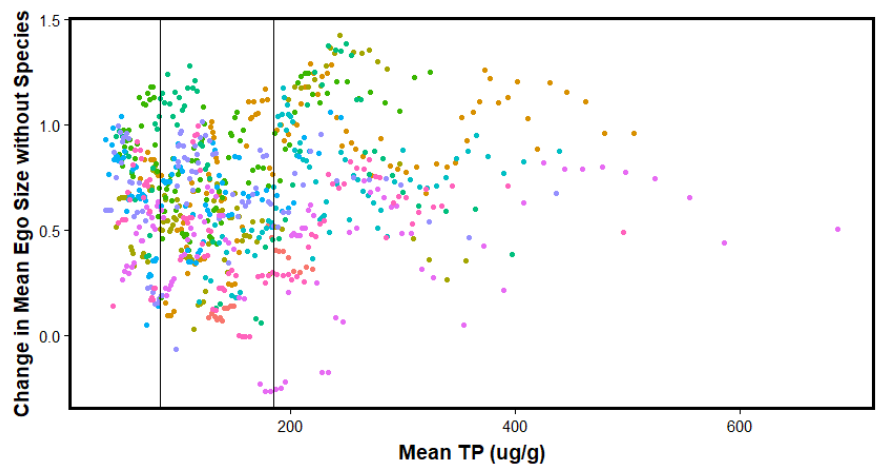

Years $: 2007: 2009: 2011: 2013: 2015$

Figure B18. Plot of Effect of species removal on mean ego size in network along a mean Total Phosphorus gradient $(\mu \mathrm{g} / \mathrm{g})$ for taxon Encyonema silesiacum var. elegans. Vertical lines indicate thresholds at 83 and $195 \mu \mathrm{g} / \mathrm{g}$. Two-way ANOVA with replication follows immediately.

Analysis of Variance Table

Response: Differences

\begin{tabular}{|l|l|l|l|l|l|}
\hline & Df & Sum Sq & Mean Sq & F value & $\operatorname{Pr}(>\mathrm{F})$ \\
\hline Year & 9 & 20.301 & 2.2556 & 40.674 & $<2.2 \mathrm{e}-16 * * *$ \\
\hline TP & 2 & 8.754 & 4.3771 & 78.928 & $<2.2 \mathrm{e}-16 * * *$ \\
\hline Year:TP & 16 & 5.487 & 0.3429 & 6.184 & $4.643 \mathrm{e}-13 * * *$ \\
\hline Residuals & 776 & 43.034 & 0.0555 & & \\
\hline
\end{tabular}

Signif. codes: 0 ‘***’ 0.001 '**’ 0.01 '*’ 0.05 '? 0.1 ' ' 1 


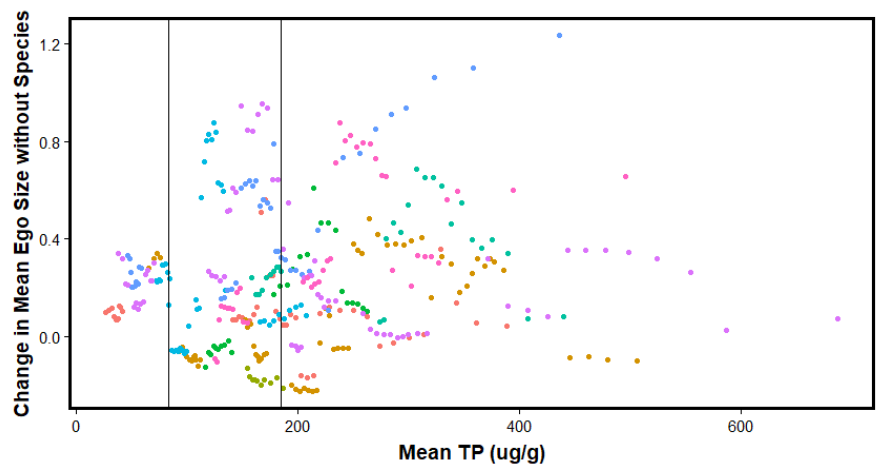

Years $: 2007: 2009: 2012: 2012: 2014 \cdot 2016$

Figure B19. Plot of Effect of species removal on mean ego size in network along a mean Total Phosphorus gradient $(\mu \mathrm{g} / \mathrm{g})$ for taxon Encyonema silesiacum. Vertical lines indicate thresholds at 83 and $195 \mu \mathrm{g} / \mathrm{g}$. Two-way ANOVA with replication follows immediately.

Analysis of Variance Table

Response: Differences

\begin{tabular}{|l|l|l|l|l|l|}
\hline & Df & Sum Sq & Mean Sq & F value & $\operatorname{Pr}(>\mathrm{F})$ \\
\hline Year & 8 & 7.7772 & 0.97216 & 23.925 & $<2 \mathrm{e}-16 * * *$ \\
\hline TP & 2 & 0.2588 & 0.12938 & 3.184 & $0.04265 *$ \\
\hline Year:TP & 12 & 6.2001 & 0.51668 & 12.716 & $<2 \mathrm{e}-16 * * *$ \\
\hline Residuals & 343 & 13.9371 & 0.04063 & & \\
\hline
\end{tabular}

Signif. codes: 0 ‘***’ 0.001 '**’ 0.01 '*’ 0.05 '? 0.1 ' ' 1 


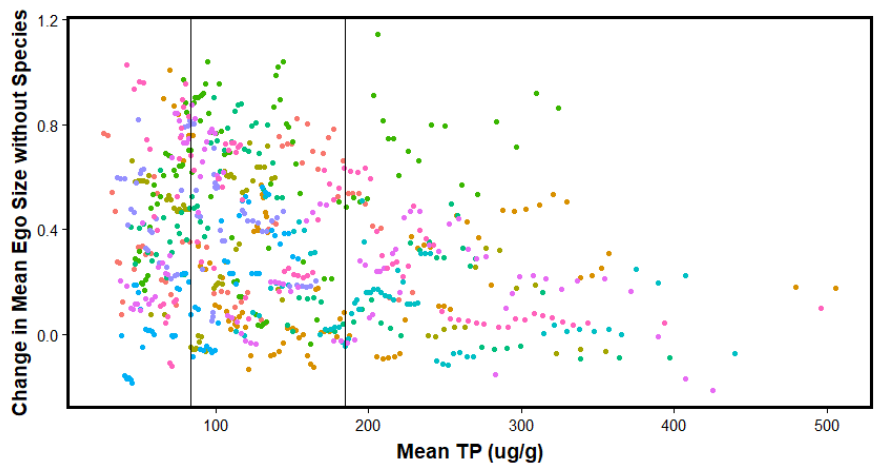

Years $: 2007: 2009: 2011: 2013: 2015$

Figure B20. Plot of Effect of species removal on mean ego size in network along a mean Total Phosphorus gradient $(\mu \mathrm{g} / \mathrm{g})$ for taxon Encyonema sjsp03. Vertical lines indicate thresholds at 83 and $195 \mu \mathrm{g} / \mathrm{g}$. Twoway ANOVA with replication follows immediately.

Analysis of Variance Table

Response: Differences

\begin{tabular}{|l|l|l|l|l|l|}
\hline & Df & Sum Sq & Mean Sq & F value & $\operatorname{Pr}(>\mathrm{F})$ \\
\hline Year & 9 & 13.607 & 1.51188 & 27.9534 & $<2.2 \mathrm{e}-16 * * *$ \\
\hline TP & 2 & 2.038 & 1.01890 & 18.8387 & $1.057 \mathrm{e}-08 * * *$ \\
\hline Year:TP & 15 & 7.487 & 0.49914 & 9.2287 & $<2.2 \mathrm{e}-16 * * *$ \\
\hline Residuals & 724 & 39.158 & 0.05409 & & \\
\hline
\end{tabular}

Signif. codes: 0 ‘***’ 0.001 '**’ 0.01 '*’ 0.05 '? 0.1 ' ' 1 


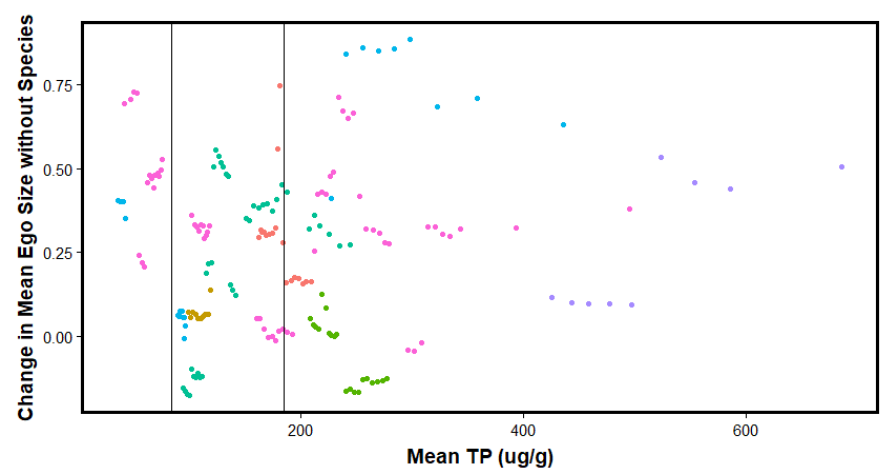

Years : $2008: 2012: 2013: 2014 \cdot 2016$

Figure B21. Plot of Effect of species removal on mean ego size in network along a mean Total Phosphorus gradient $(\mu \mathrm{g} / \mathrm{g})$ for taxon Eunotia egsp01. Vertical lines indicate thresholds at 83 and $195 \mu \mathrm{g} / \mathrm{g}$. Two-way ANOVA with replication follows immediately.

Analysis of Variance Table

Response: Differences

\begin{tabular}{|l|l|l|l|l|l|}
\hline & Df & Sum Sq & Mean Sq & F value & $\operatorname{Pr}(>\mathrm{F})$ \\
\hline Year & 6 & 3.0497 & 0.50828 & 16.833 & $3.448 \mathrm{e}-15 * * *$ \\
\hline TP & 2 & 1.2706 & 0.63529 & 21.039 & $6.935 \mathrm{e}-09 * * *$ \\
\hline Year:TP & 4 & 2.0421 & 0.51053 & 16.907 & $1.117 \mathrm{e}-11 * * *$ \\
\hline Residuals & 169 & 5.1031 & 0.03020 & & \\
\hline
\end{tabular}

Signif. codes: 0 ‘***’ 0.001 '**’ 0.01 '*’ 0.05 '? 0.1 ' ' 1 


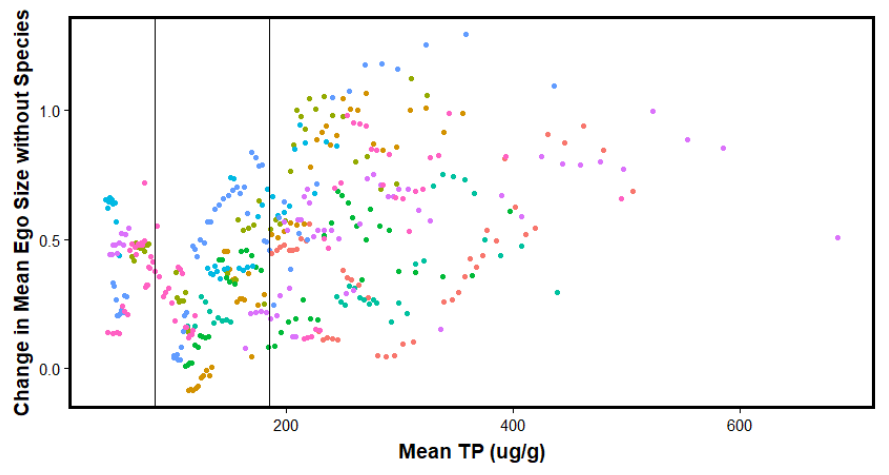

Years $: 2009: 2010: 2012: 2014 \cdot 2016$

Figure B22. Plot of Effect of species removal on mean ego size in network along a mean Total Phosphorus gradient $(\mu \mathrm{g} / \mathrm{g})$ for taxon Eunotia flexuosa. Vertical lines indicate thresholds at 83 and $195 \mu \mathrm{g} / \mathrm{g}$. Two-way ANOVA with replication follows immediately.

Analysis of Variance Table

Response: Differences

\begin{tabular}{|l|l|l|l|l|l|}
\hline & Df & Sum Sq & Mean Sq & F value & $\operatorname{Pr}(>\mathrm{F})$ \\
\hline Year & 8 & 2.9264 & 0.3658 & 8.9829 & $2.142 \mathrm{e}-11 * * *$ \\
\hline TP & 2 & 11.3457 & 5.6728 & 139.3059 & $<2.2 \mathrm{e}-16 * * *$ \\
\hline Year:TP & 11 & 3.0266 & 0.2751 & 6.7567 & $1.786 \mathrm{e}-10 * * *$ \\
\hline Residuals & 418 & 17.0219 & 0.0407 & & \\
\hline
\end{tabular}

Signif. codes: 0 ‘***’ 0.001 '**’ 0.01 '*’ 0.05 '? 0.1 ' ' 1 


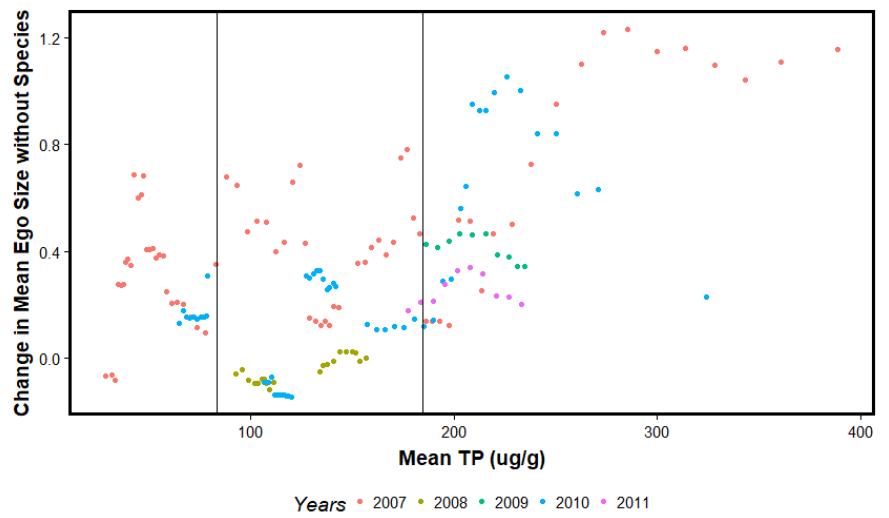

Figure B23. Plot of Effect of species removal on mean ego size in network along a mean Total Phosphorus gradient $(\mu \mathrm{g} / \mathrm{g})$ for taxon Eunotia formica. Vertical lines indicate thresholds at 83 and $195 \mu \mathrm{g} / \mathrm{g}$. Two-way ANOVA with replication follows immediately.

Analysis of Variance Table

Response: Differences

\begin{tabular}{|l|l|l|l|l|l|}
\hline & Df & Sum Sq & Mean Sq & F value & $\operatorname{Pr}(>\mathrm{F})$ \\
\hline Year & 4 & 4.3823 & 1.09556 & 20.5235 & $1.279 \mathrm{e}-13 * * *$ \\
\hline TP & 2 & 5.0625 & 2.53127 & 47.4190 & $<2.2 \mathrm{e}-16 * * *$ \\
\hline Year:TP & 3 & 0.5657 & 0.18858 & 3.5327 & $0.01627 *$ \\
\hline Residuals & 157 & 8.3808 & 0.05338 & & \\
\hline
\end{tabular}

Signif. codes: 0 ‘***’ 0.001 '**’ 0.01 '*’ 0.05 '? 0.1 ' ' 1 


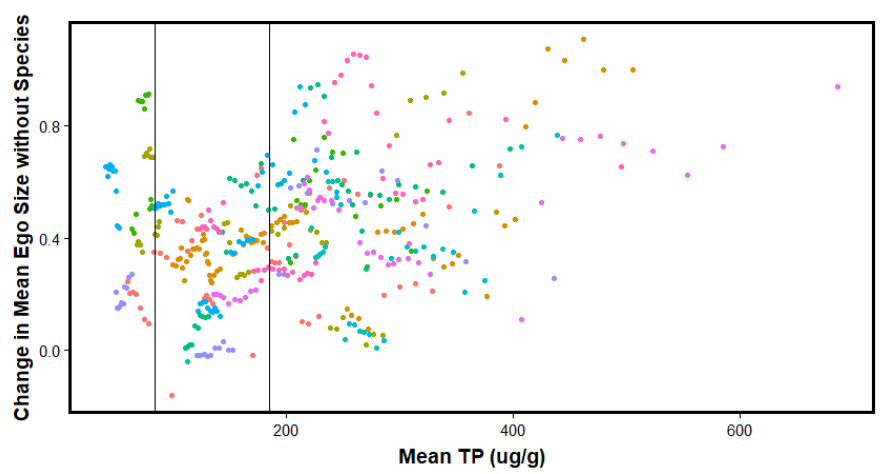

Years $: 2007: 2009: 2011: 2013: 2015$

Figure B24. Plot of Effect of species removal on mean ego size in network along a mean Total Phosphorus gradient $(\mu \mathrm{g} / \mathrm{g})$ for taxon Eunotia naegelii. Vertical lines indicate thresholds at 83 and $195 \mu \mathrm{g} / \mathrm{g}$. Two-way ANOVA with replication follows immediately.

Analysis of Variance Table

Response: Differences

\begin{tabular}{|l|l|l|l|l|l|}
\hline & Df & Sum Sq & Mean Sq & F value & $\operatorname{Pr}(>\mathrm{F})$ \\
\hline Year & 9 & 3.7604 & 0.41783 & 11.0022 & $1.962 \mathrm{e}-15 * * *$ \\
\hline TP & 2 & 3.7695 & 1.88477 & 49.6300 & $<2.2 \mathrm{e}-16 * * *$ \\
\hline Year:TP & 12 & 1.9885 & 0.16571 & 4.3634 & $1.446 \mathrm{e}-06 * * *$ \\
\hline Residuals & 418 & 15.8742 & 0.03798 & & \\
\hline
\end{tabular}

Signif. codes: 0 ‘***’ 0.001 '**’ 0.01 '*’ 0.05 '? 0.1 ' ' 1 


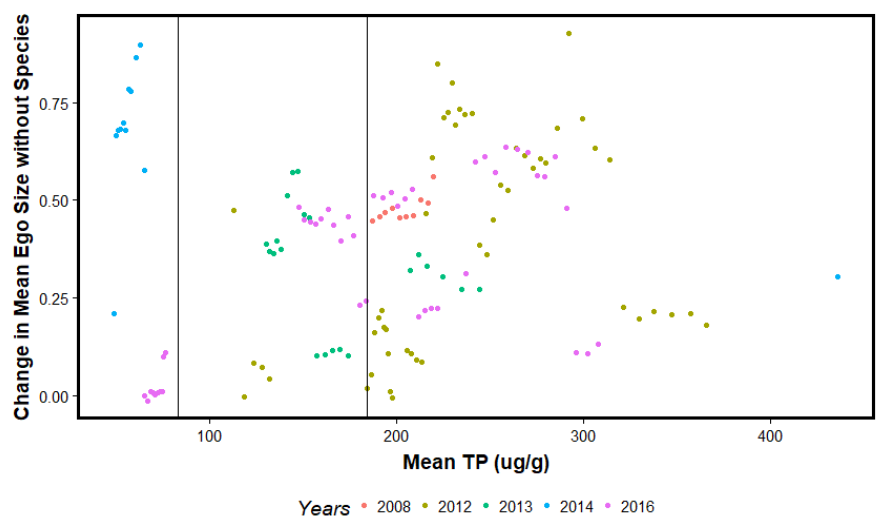

Figure B25. Plot of Effect of species removal on mean ego size in network along a mean Total Phosphorus gradient $(\mu \mathrm{g} / \mathrm{g})$ for taxon Fragilaria cf. tenera. Vertical lines indicate thresholds at 83 and $195 \mu \mathrm{g} / \mathrm{g}$. Twoway ANOVA with replication follows immediately.

Analysis of Variance Table

Response: Differences

\begin{tabular}{|l|l|l|l|l|l|}
\hline & Df & Sum Sq & Mean Sq & F value & $\operatorname{Pr}(>\mathrm{F})$ \\
\hline Year & 4 & 1.0995 & 0.27487 & 7.0930 & $3.409 \mathrm{e}-05 * * *$ \\
\hline TP & 2 & 1.0335 & 0.51675 & 13.3347 & $5.444 \mathrm{e}-06 * * *$ \\
\hline Year:TP & 3 & 0.8834 & 0.29448 & 7.5989 & $0.0001017 * * *$ \\
\hline Residuals & 129 & 4.9991 & 0.03875 & & \\
\hline
\end{tabular}

Signif. codes: 0 ‘***’ 0.001 '**’ 0.01 '*’ 0.05 '? 0.1 ' ' 1 


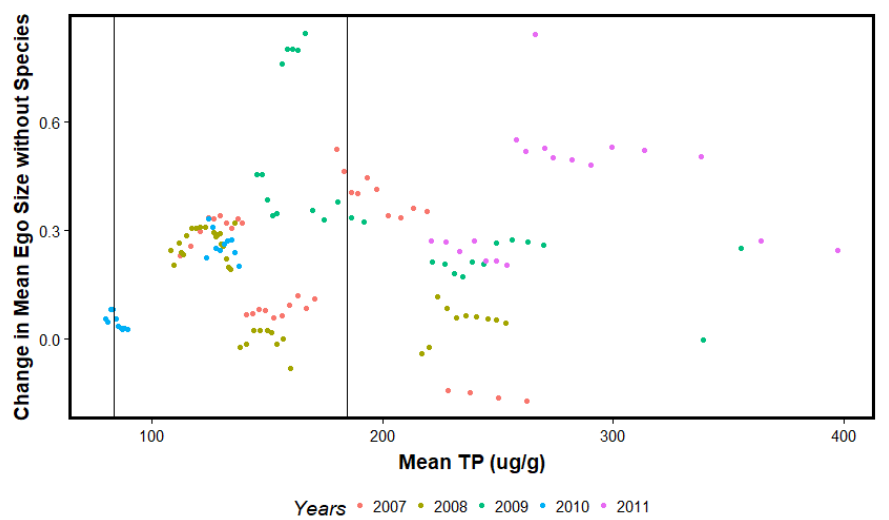

Figure B26. Plot of Effect of species removal on mean ego size in network along a mean Total Phosphorus gradient $(\mu \mathrm{g} / \mathrm{g})$ for taxon Fragilaria ftsp16. Vertical lines indicate thresholds at 83 and $195 \mu \mathrm{g} / \mathrm{g}$. Two-way ANOVA with replication follows immediately.

Analysis of Variance Table

Response: Differences

\begin{tabular}{|l|l|l|l|l|l|}
\hline & Df & Sum Sq & Mean Sq & F value & $\operatorname{Pr}(>\mathrm{F})$ \\
\hline Year & 4 & 1.53321 & 0.38330 & 15.921 & $1.245 \mathrm{e}-10 * * *$ \\
\hline TP & 2 & 0.52855 & 0.26427 & 10.977 & $3.937 \mathrm{e}-05 * * *$ \\
\hline Year:TP & 2 & 0.32112 & 0.16056 & 6.669 & $0.001749 * *$ \\
\hline Residuals & 130 & 3.12986 & 0.02408 & & \\
\hline
\end{tabular}

Signif. codes: 0 ‘***’ 0.001 '**’ 0.01 '*’ 0.05 '? 0.1 ' ' 1 


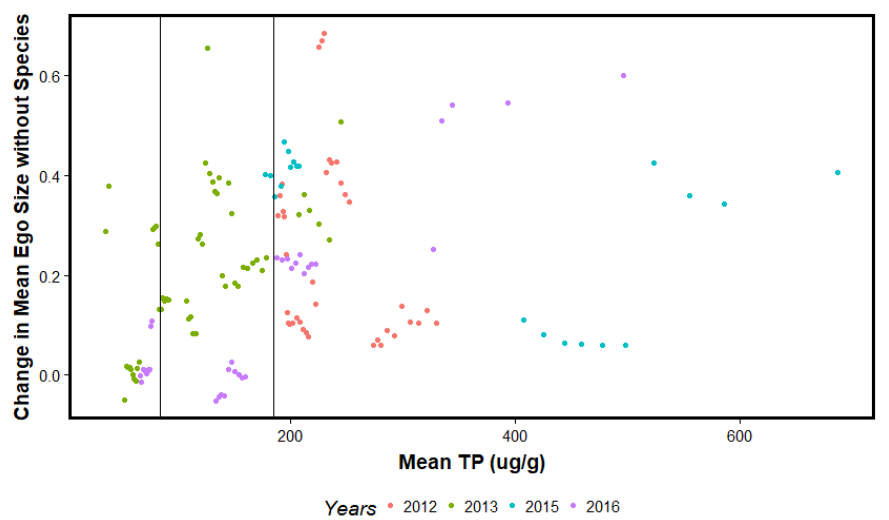

Figure B27. Plot of Effect of species removal on mean ego size in network along a mean Total Phosphorus gradient $(\mu \mathrm{g} / \mathrm{g})$ for taxon Fragilariforma virescens var. capitata. Vertical lines indicate thresholds at 83 and $195 \mu \mathrm{g} / \mathrm{g}$. Two-way ANOVA with replication follows immediately.

Analysis of Variance Table

Response: Differences

\begin{tabular}{|l|l|l|l|l|l|}
\hline & Df & Sum Sq & Mean Sq & F value & $\operatorname{Pr}(>\mathrm{F})$ \\
\hline Year & 3 & 0.40196 & 0.13399 & 6.4435 & $0.0004085 * * *$ \\
\hline TP & 2 & 0.82015 & 0.41008 & 19.7205 & $2.93 \mathrm{e}-08 * * *$ \\
\hline Year:TP & 3 & 0.32595 & 0.10865 & 5.2250 & $0.0019040 * *$ \\
\hline Residuals & 138 & 2.86963 & 0.02079 & & \\
\hline
\end{tabular}

Signif. codes: 0 ‘***’ 0.001 '**’ 0.01 '*’ 0.05 '? 0.1 ' ' 1 


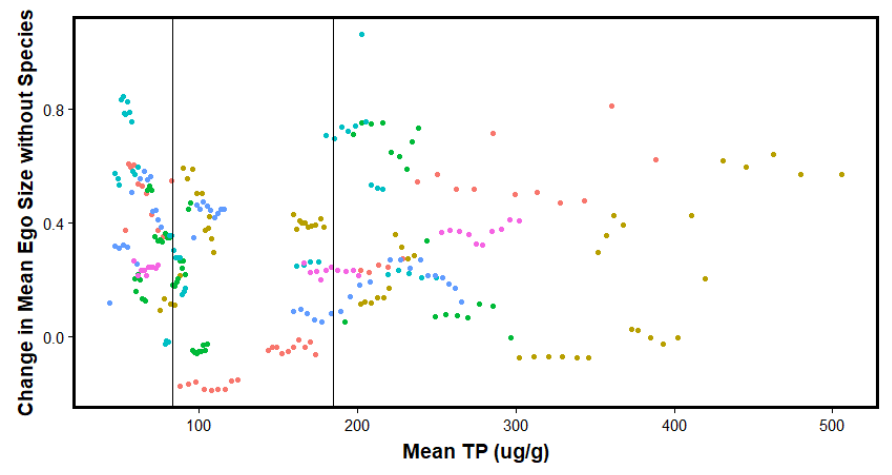

Years : $2007: 2009: 2010: 2011$

Figure B28. Plot of Effect of species removal on mean ego size in network along a mean Total Phosphorus gradient $(\mu \mathrm{g} / \mathrm{g})$ for taxon Frustulia crassinervia. Vertical lines indicate thresholds at 83 and $195 \mu \mathrm{g} / \mathrm{g}$. Twoway ANOVA with replication follows immediately.

Analysis of Variance Table

Response: Differences

\begin{tabular}{|l|l|l|l|l|l|}
\hline & Df & Sum Sq & Mean Sq & F value & $\operatorname{Pr}(>\mathrm{F})$ \\
\hline Year & 5 & 1.3827 & 0.27654 & 8.2012 & $3.324 \mathrm{e}-07 * * *$ \\
\hline TP & 2 & 1.4322 & 0.71610 & 21.2374 & $2.895 \mathrm{e}-09 * * *$ \\
\hline Year:TP & 10 & 4.5830 & 0.45830 & 13.5917 & $<2.2 \mathrm{e}-16 * * *$ \\
\hline Residuals & 258 & 8.6995 & 0.03372 & & \\
\hline
\end{tabular}

Signif. codes: 0 ‘***’ 0.001 '**’ 0.01 '*’ 0.05 '? 0.1 ' ' 1 


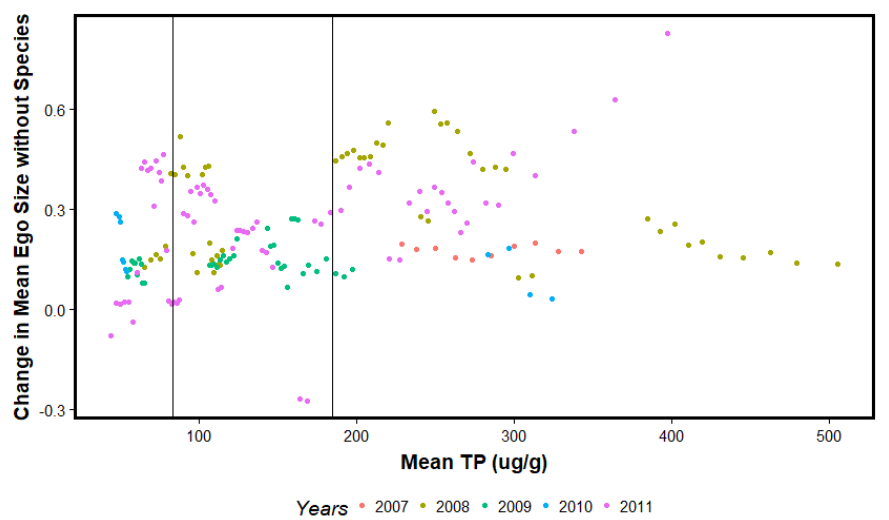

Figure B29. Plot of Effect of species removal on mean ego size in network along a mean Total Phosphorus gradient $(\mu \mathrm{g} / \mathrm{g})$ for taxon Gomphonema affine. Vertical lines indicate thresholds at 83 and $195 \mu \mathrm{g} / \mathrm{g}$. Twoway ANOVA with replication follows immediately.

Analysis of Variance Table

Response: Differences

\begin{tabular}{|l|l|l|l|l|l|}
\hline & Df & Sum Sq & Mean Sq & F value & $\operatorname{Pr}(>\mathrm{F})$ \\
\hline Year & 4 & 0.7504 & 0.187604 & 9.6942 & $4.254 \mathrm{e}-07 * * *$ \\
\hline TP & 2 & 0.4182 & 0.209096 & 10.8047 & $3.787 \mathrm{e}-05 * * *$ \\
\hline Year:TP & 5 & 0.2621 & 0.052417 & 2.7086 & $0.02201 *$ \\
\hline Residuals & 173 & 3.3479 & 0.019352 & & \\
\hline
\end{tabular}

Signif. codes: 0 ‘***’ 0.001 '**’ 0.01 '*’ 0.05 '? 0.1 ' ' 1 


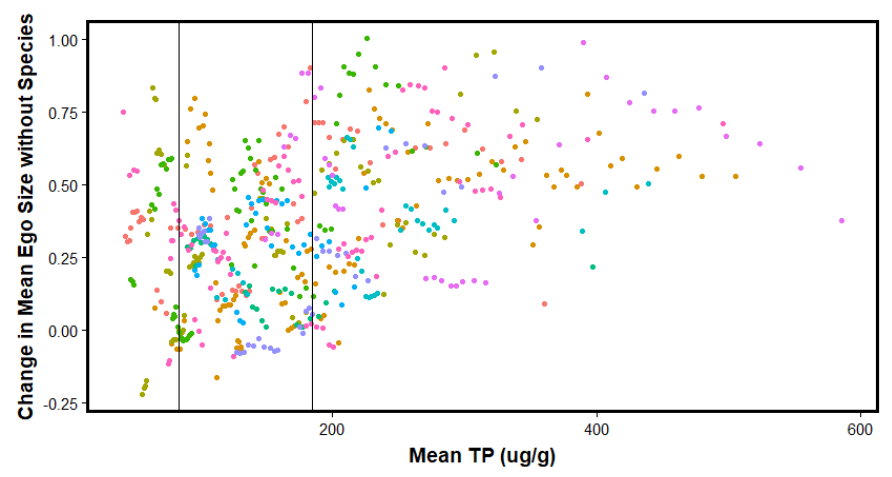

Years $: 2007: 2009: 2010: 2011: 2013: 2014: 2016$

Figure B30. Plot of Effect of species removal on mean ego size in network along a mean Total Phosphorus gradient $(\mu \mathrm{g} / \mathrm{g})$ for taxon Gomphonema cf. vibrioides. Vertical lines indicate thresholds at 83 and $195 \mu \mathrm{g} / \mathrm{g}$. Two-way ANOVA with replication follows immediately.

Analysis of Variance Table

Response: Differences

\begin{tabular}{|l|l|l|l|l|l|}
\hline & Df & Sum Sq & Mean Sq & F value & $\operatorname{Pr}(>\mathrm{F})$ \\
\hline Year & 9 & 3.1186 & 0.34651 & 7.0936 & $9.842 \mathrm{e}-10 * * *$ \\
\hline TP & 2 & 5.5397 & 2.76985 & 56.7032 & $<2.2 \mathrm{e}-16 * * *$ \\
\hline Year:TP & 13 & 1.9638 & 0.15107 & 3.0925 & $0.0001887 * * *$ \\
\hline Residuals & 534 & 26.0849 & 0.04885 & & \\
\hline
\end{tabular}

Signif. codes: 0 “***’ 0.001 '**, 0.01 '*’ 0.05 '? 0.1 ' ' 1 


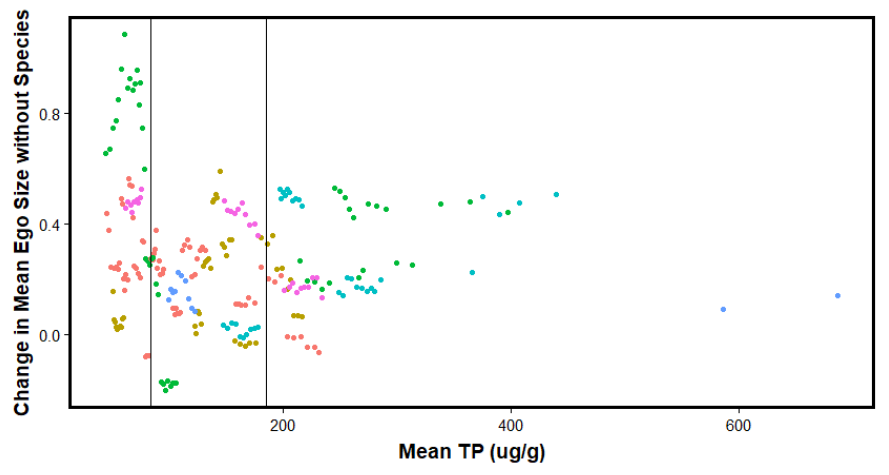

Years : $200902011: 2015$

Figure B31. Plot of Effect of species removal on mean ego size in network along a mean Total Phosphorus gradient $(\mu \mathrm{g} / \mathrm{g})$ for taxon Gomphonema gracile. Vertical lines indicate thresholds at 83 and $195 \mu \mathrm{g} / \mathrm{g}$. Twoway ANOVA with replication follows immediately.

Analysis of Variance Table

Response: Differences

\begin{tabular}{|l|l|l|l|l|l|}
\hline & Df & Sum Sq & Mean Sq & F value & $\operatorname{Pr}(>\mathrm{F})$ \\
\hline Year & 5 & 2.1211 & 0.42422 & 19.595 & $3.526 \mathrm{e}-16 * * *$ \\
\hline TP & 2 & 1.4234 & 0.71172 & 32.874 & $3.030 \mathrm{e}-13 * * *$ \\
\hline Year:TP & 8 & 4.9191 & 0.61489 & 28.402 & $<2.2 \mathrm{e}-16 * * *$ \\
\hline Residuals & 224 & 4.8495 & 0.02165 & & \\
\hline
\end{tabular}

Signif. codes: 0 ‘***’ 0.001 '**’ 0.01 '*’ 0.05 '? 0.1 ' ' 1 


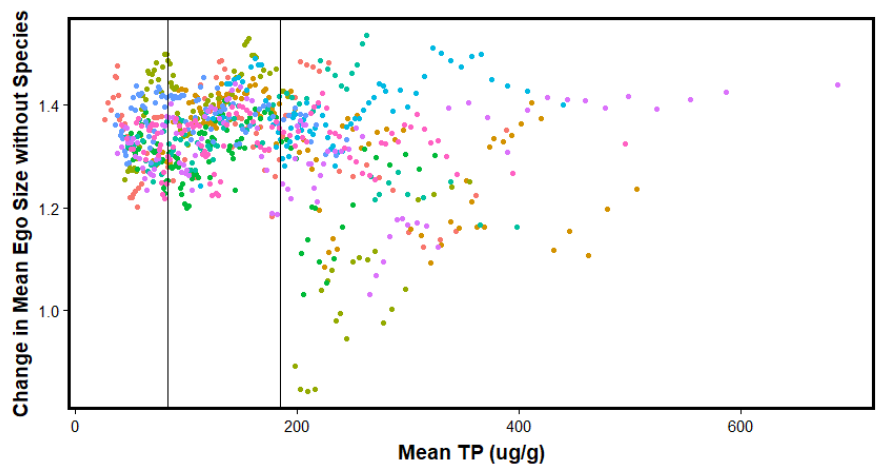

Years $: 2007: 2009 \cdot 2010: 2011: 2013 \cdot 2015$

Figure B32. Plot of Effect of species removal on mean ego size in network along a mean Total Phosphorus gradient $(\mu \mathrm{g} / \mathrm{g})$ for taxon Mastogloia calcarea. Vertical lines indicate thresholds at 83 and $195 \mu \mathrm{g} / \mathrm{g}$. Twoway ANOVA with replication follows immediately.

Analysis of Variance Table

Response: Differences

\begin{tabular}{|l|l|l|l|l|l|}
\hline & Df & Sum Sq & Mean Sq & F value & $\operatorname{Pr}(>\mathrm{F})$ \\
\hline Year & 8 & 0.5996 & 0.07495 & 14.187 & $<2.2 \mathrm{e}-16^{* * *}$ \\
\hline TP & 2 & 0.8935 & 0.44676 & 84.566 & $<2.2 \mathrm{e}-16 * * *$ \\
\hline Year:TP & 15 & 1.6987 & 0.11325 & 21.437 & $<2.2 \mathrm{e}-16 * * *$ \\
\hline Residuals & 791 & 4.1788 & 0.00528 & & \\
\hline
\end{tabular}

Signif. codes: 0 ‘***’ 0.001 '**’ 0.01 '*’ 0.05 '? 0.1 ' ' 1 


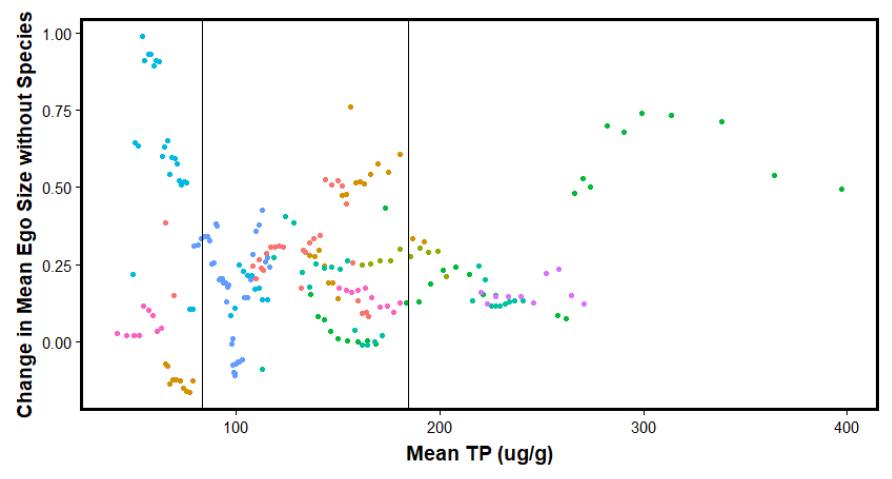

Years : $2008: 2010: 2011: 2012: 2014 \cdot 2015$

Figure B33. Plot of Effect of species removal on mean ego size in network along a mean Total Phosphorus gradient $(\mu \mathrm{g} / \mathrm{g})$ for taxon Mastogloia lanceolata. Vertical lines indicate thresholds at 83 and $195 \mu \mathrm{g} / \mathrm{g}$. Two-way ANOVA with replication follows immediately.

Analysis of Variance Table

Response: Differences

\begin{tabular}{|l|l|l|l|l|l|}
\hline & Df & Sum Sq & Mean Sq & F value & $\operatorname{Pr}(>\mathrm{F})$ \\
\hline Year & 8 & 2.9231 & 0.36539 & 15.0910 & $<2.2 \mathrm{e}-16 * * *$ \\
\hline TP & 2 & 0.3341 & 0.16705 & 6.8994 & $0.001258^{* *}$ \\
\hline Year:TP & 7 & 3.8663 & 0.55234 & 22.8120 & $<2.2 \mathrm{e}-16 * * *$ \\
\hline Residuals & 206 & 4.9878 & 0.02421 & & \\
\hline
\end{tabular}

Signif. codes: 0 ‘***’ 0.001 '**’ 0.01 '*’ 0.05 '? 0.1 ' ’ 1 


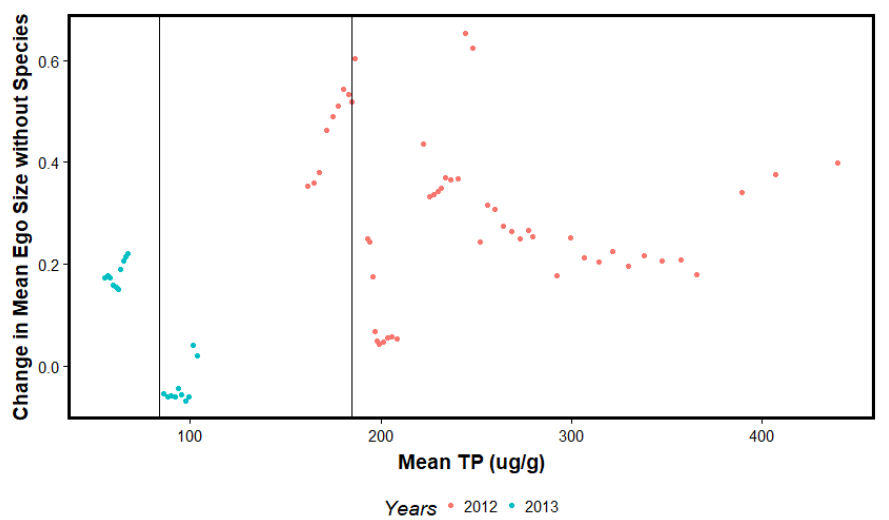

Figure B34. Plot of Effect of species removal on mean ego size in network along a mean Total Phosphorus gradient $(\mu \mathrm{g} / \mathrm{g})$ for taxon Navicula densilineolata. Vertical lines indicate thresholds at 83 and $195 \mu \mathrm{g} / \mathrm{g}$. Two-way ANOVA with replication follows immediately.

Analysis of Variance Table

\section{Response: Differences}

\begin{tabular}{|l|l|l|l|l|l|}
\hline & Df & Sum Sq & Mean Sq & F value & $\operatorname{Pr}(>\mathrm{F})$ \\
\hline Year & 1 & 0.76378 & 0.76378 & 53.866 & $3.728 \mathrm{e}-10 * * *$ \\
\hline TP & 2 & 0.53074 & 0.26537 & 18.716 & $3.489 \mathrm{e}-07 * * *$ \\
\hline Residuals & 67 & 0.95000 & 0.01418 & & \\
\hline
\end{tabular}

Signif. codes: 0 “***’ 0.001 '**, 0.01 '*’ 0.05 '. 0.1 ' ' 1 


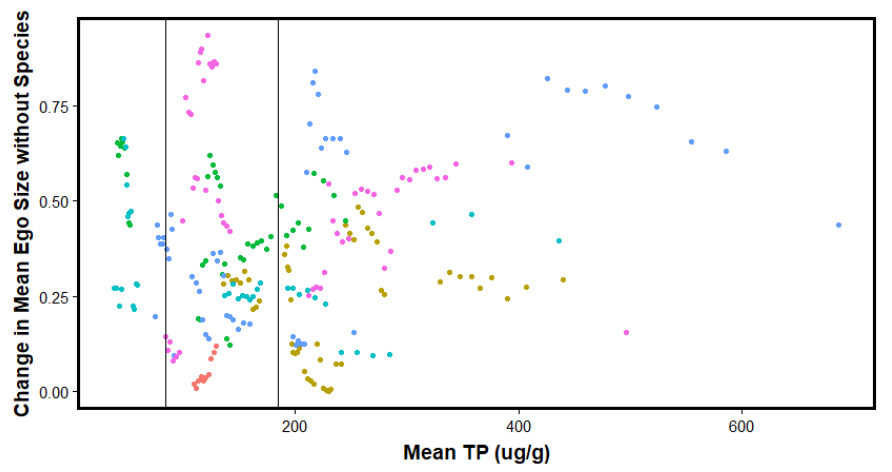

Years : $2009: 2012: 2014: 2015$

Figure B35. Plot of Effect of species removal on mean ego size in network along a mean Total Phosphorus gradient $(\mu \mathrm{g} / \mathrm{g})$ for taxon Navicula radiosafallax. Vertical lines indicate thresholds at 83 and $195 \mu \mathrm{g} / \mathrm{g}$. Two-way ANOVA with replication follows immediately.

Analysis of Variance Table

Response: Differences

\begin{tabular}{|l|l|l|l|l|l|}
\hline & Df & Sum Sq & Mean Sq & F value & $\operatorname{Pr}(>\mathrm{F})$ \\
\hline Year & 5 & 3.6491 & 0.72981 & 25.7406 & $<2.2 \mathrm{e}-16 * * *$ \\
\hline TP & 2 & 0.3405 & 0.17025 & 6.0047 & $0.002858 * *$ \\
\hline Year:TP & 6 & 1.4255 & 0.23758 & 8.3794 & $2.998 \mathrm{e}-08 * * *$ \\
\hline Residuals & 237 & 6.7196 & 0.02835 & & \\
\hline
\end{tabular}

Signif. codes: 0 “***’ 0.001 '**’ 0.01 '*’ 0.05 '? 0.1 ' ' 1 


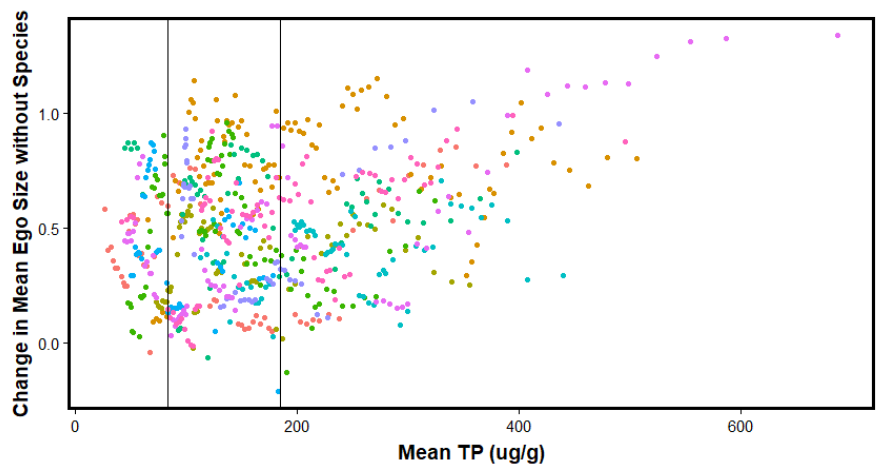

Years $: 2007: 2009: 2010: 2012: 2013: 2015 \cdot 2016$

Figure B36. Plot of Effect of species removal on mean ego size in network along a mean Total Phosphorus gradient $(\mu \mathrm{g} / \mathrm{g})$ for taxon Nitzschia amphibia. Vertical lines indicate thresholds at 83 and $195 \mu \mathrm{g} / \mathrm{g}$. Twoway ANOVA with replication follows immediately.

Analysis of Variance Table

Response: Differences

\begin{tabular}{|l|l|l|l|l|l|}
\hline & Df & Sum Sq & Mean Sq & F value & $\operatorname{Pr}(>\mathrm{F})$ \\
\hline Year & 9 & 10.972 & 1.21914 & 23.2188 & $<2.2 \mathrm{e}-16 * * *$ \\
\hline TP & 2 & 1.218 & 0.60905 & 11.5994 & $1.121 \mathrm{e}-05 * * *$ \\
\hline Year:TP & 15 & 7.488 & 0.49919 & 9.5072 & $<2.2 \mathrm{e}-16 * * *$ \\
\hline Residuals & 654 & 34.339 & 0.05251 & & \\
\hline
\end{tabular}

Signif. codes: 0 ‘***’ 0.001 '**’ 0.01 '*’ 0.05 '? 0.1 ' ' 1 


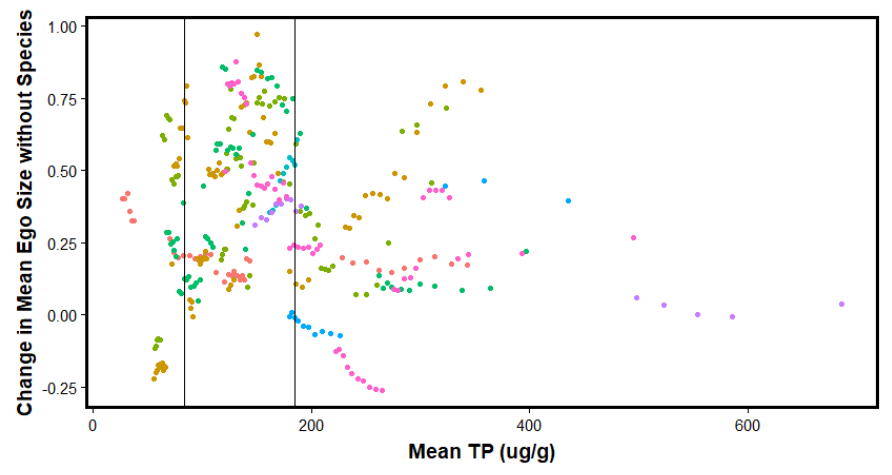

Years $: 2007: 2010: 2012: 2015$

Figure B37. Plot of Effect of species removal on mean ego size in network along a mean Total Phosphorus gradient $(\mu \mathrm{g} / \mathrm{g})$ for taxon Nitzschia cf. semirobusta. Vertical lines indicate thresholds at 83 and $195 \mu \mathrm{g} / \mathrm{g}$. Two-way ANOVA with replication follows immediately.

Analysis of Variance Table

Response: Differences

\begin{tabular}{|l|l|l|l|l|l|}
\hline & Df & Sum Sq & Mean Sq & F value & $\operatorname{Pr}(>\mathrm{F})$ \\
\hline Year & 7 & 2.5101 & 0.35858 & 6.9192 & $1.159 \mathrm{e}-07 * * *$ \\
\hline TP & 2 & 3.3827 & 1.69137 & 32.6364 & $1.360 \mathrm{e}-13 * * *$ \\
\hline Year:TP & 10 & 3.2240 & 0.32240 & 6.2210 & $1.109 \mathrm{e}-08 * * *$ \\
\hline Residuals & 311 & 16.1175 & 0.05182 & & \\
\hline
\end{tabular}

Signif. codes: 0 ‘***’ 0.001 '**’ 0.01 '*’ 0.05 '? 0.1 ' ' 1 


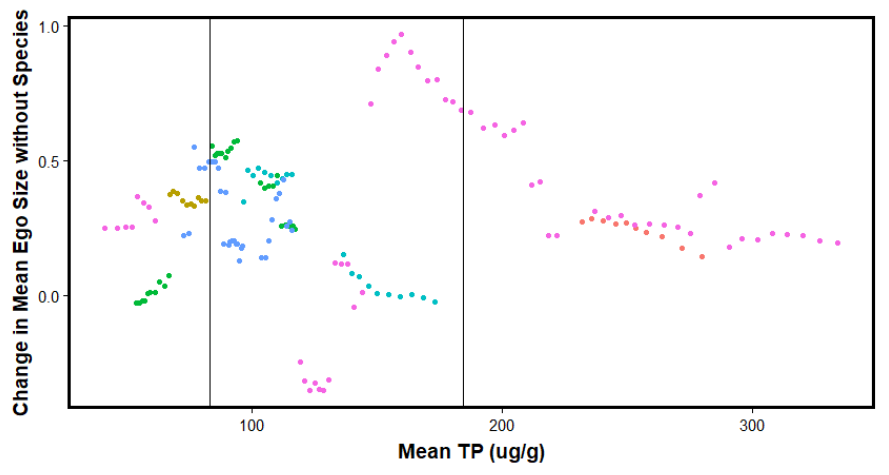

Years : $2008: 2009: 2011: 2014$

Figure B38. Plot of Effect of species removal on mean ego size in network along a mean Total Phosphorus gradient $(\mu \mathrm{g} / \mathrm{g})$ for taxon Nitzschia ftsp16. Vertical lines indicate thresholds at 83 and $195 \mu \mathrm{g} / \mathrm{g}$. Two-way ANOVA with replication follows immediately.

Analysis of Variance Table

Response: Differences

\begin{tabular}{|l|l|l|l|l|l|}
\hline & Df & Sum Sq & Mean Sq & F value & $\operatorname{Pr}(>\mathrm{F})$ \\
\hline Year & 5 & 0.2135 & 0.04270 & 0.7439 & 0.5917673 \\
\hline TP & 2 & 0.3471 & 0.17355 & 3.0235 & 0.0515839. \\
\hline Year:TP & 2 & 0.9788 & 0.48940 & 8.5263 & $0.0003102 * * *$ \\
\hline Residuals & 151 & 8.6672 & 0.05740 & & \\
\hline
\end{tabular}

Signif. codes: 0 ‘***’ 0.001 '**’ 0.01 '*’ 0.05 '? 0.1 ' ' 1 


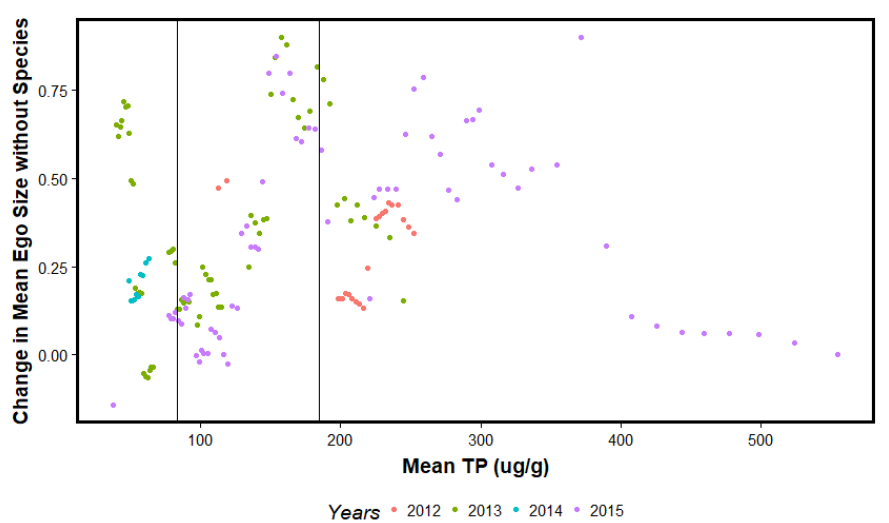

Figure B39. Plot of Effect of species removal on mean ego size in network along a mean Total Phosphorus gradient $(\mu \mathrm{g} / \mathrm{g})$ for taxon Nitzscia intermedia. Vertical lines indicate thresholds at 83 and $195 \mu \mathrm{g} / \mathrm{g}$. Twoway ANOVA with replication follows immediately.

Analysis of Variance Table

Response: Differences

\begin{tabular}{|l|l|l|l|l|l|}
\hline & Df & Sum Sq & Mean Sq & F value & $\operatorname{Pr}(>\mathrm{F})$ \\
\hline Year & 3 & 0.2846 & 0.094859 & 1.6015 & 0.191241 \\
\hline TP & 2 & 0.5704 & 0.285196 & 4.8151 & $0.009342 * *$ \\
\hline Year:TP & 3 & 0.3380 & 0.112655 & 1.9020 & 0.131491 \\
\hline Residuals & 157 & 9.2990 & 0.059229 & & \\
\hline
\end{tabular}

Signif. codes: 0 ‘***’ 0.001 '**’ 0.01 '*’ 0.05 '? 0.1 ' ' 1 


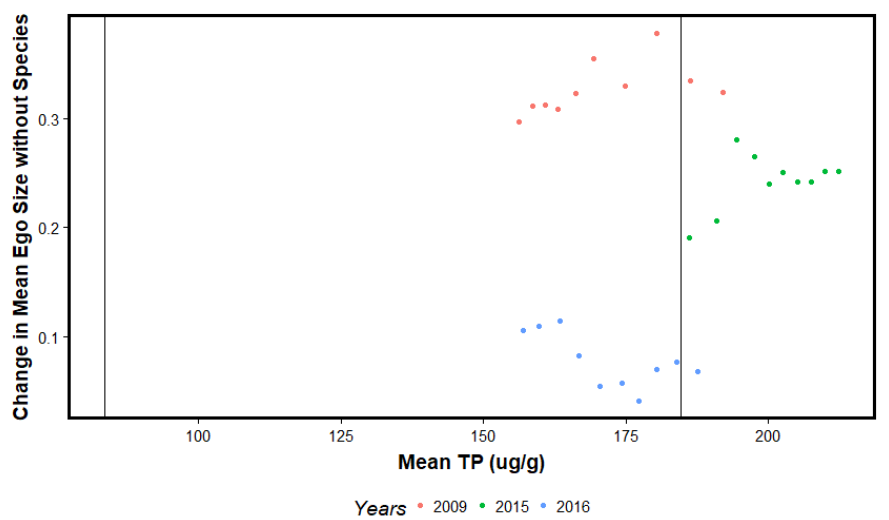

Figure B40. Plot of Effect of species removal on mean ego size in network along a mean Total Phosphorus gradient $(\mu \mathrm{g} / \mathrm{g})$ for taxon Nitzschia microcephala. Vertical lines indicate thresholds at 83 and $195 \mu \mathrm{g} / \mathrm{g}$. Two-way ANOVA with replication follows immediately.

Analysis of Variance Table

Response: Differences

\begin{tabular}{|l|l|l|l|l|l|}
\hline & Df & Sum Sq & Mean Sq & F value & $\operatorname{Pr}(>\mathrm{F})$ \\
\hline Year & 2 & 0.32337 & 0.161687 & 238.3503 & $<2 \mathrm{e}-16 * * *$ \\
\hline TP & 1 & 0.00002 & 0.000015 & 0.0227 & 0.8816 \\
\hline Year:TP & 1 & 0.00011 & 0.000107 & 0.1578 & 0.6946 \\
\hline Residuals & 25 & 0.01696 & 0.000678 & & \\
\hline
\end{tabular}

Signif. codes: 0 ‘***’ 0.001 '**’ 0.01 '*’ 0.05 '? 0.1 ' ' 1 


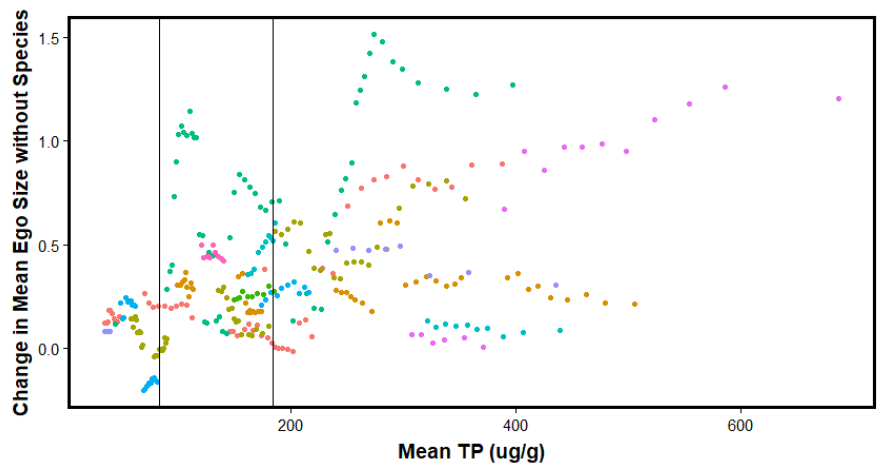

Years $: 2007: 2009: 2010: 2011: 2013: 2014: 2015$

Figure B41. Plot of Effect of species removal on mean ego size in network along a mean Total Phosphorus gradient $(\mu \mathrm{g} / \mathrm{g})$ for taxon Nitzschia nana. Vertical lines indicate thresholds at 83 and $195 \mu \mathrm{g} / \mathrm{g}$. Two-way ANOVA with replication follows immediately.

Analysis of Variance Table

Response: Differences

\begin{tabular}{|l|l|l|l|l|l|}
\hline & Df & Sum Sq & Mean Sq & F value & $\operatorname{Pr}(>\mathrm{F})$ \\
\hline Year & 9 & 13.5546 & 1.50607 & 25.0108 & $<2.2 \mathrm{e}-16 * * *$ \\
\hline TP & 2 & 4.0590 & 2.02952 & 33.7035 & $7.047 \mathrm{e}-14 * * *$ \\
\hline Year:TP & 11 & 2.7981 & 0.25437 & 4.2243 & $8.068 \mathrm{e}-06 * * *$ \\
\hline Residuals & 288 & 17.3425 & 0.06022 & & \\
\hline
\end{tabular}

Signif. codes: 0 ‘***’ 0.001 '**’ 0.01 '*’ 0.05 '? 0.1 ' ' 1 


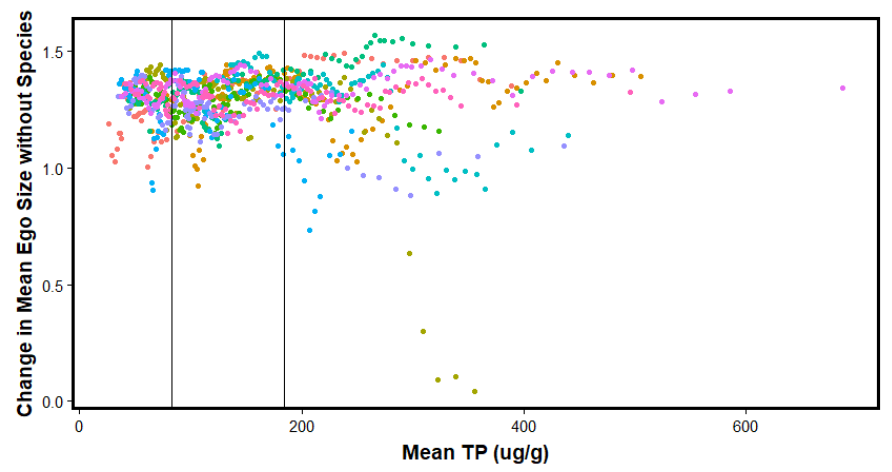

Years $: 2007: 2009: 2010: 2011: 2013: 2014: 2016$

Figure B42. Plot of Effect of species removal on mean ego size in network along a mean Total Phosphorus gradient $(\mu \mathrm{g} / \mathrm{g})$ for taxon Nitzschia palea var. debilis. Vertical lines indicate thresholds at 83 and $195 \mu \mathrm{g} / \mathrm{g}$. Two-way ANOVA with replication follows immediately.

Analysis of Variance Table

Response: Differences

\begin{tabular}{|l|l|l|l|l|l|}
\hline & Df & Sum Sq & Mean Sq & F value & $\operatorname{Pr}(>\mathrm{F})$ \\
\hline Year & 9 & 1.1245 & 0.124940 & 9.4512 & $7.96 \mathrm{e}-14 * * *$ \\
\hline TP & 2 & 0.1297 & 0.064859 & 4.9063 & $0.007602 * *$ \\
\hline Year:TP & 17 & 3.7626 & 0.221330 & 16.7428 & $<2.2 \mathrm{e}-16 * * *$ \\
\hline Residuals & 888 & 11.7389 & 0.013219 & & \\
\hline
\end{tabular}

Signif. codes: 0 ‘***’ 0.001 '**’ 0.01 '*’ 0.05 '? 0.1 ' ' 1 


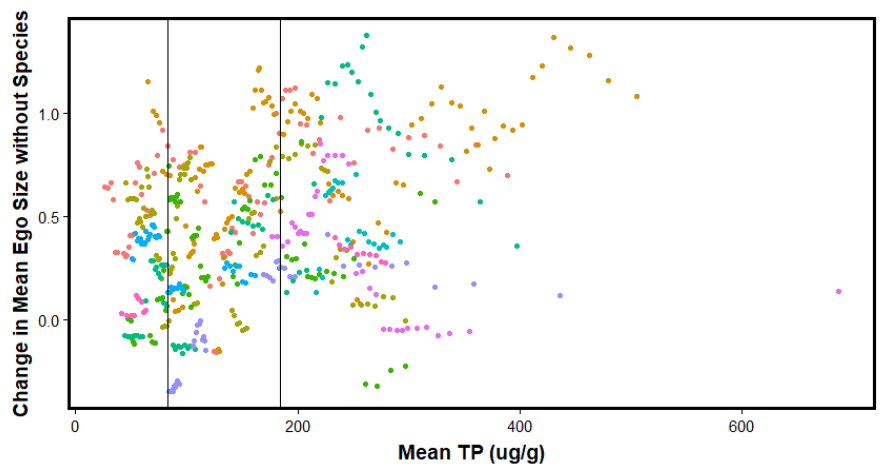

Years $: 2007: 2009: 2010: 2011: 2013: 2014: 2015$

Figure B43. Plot of Effect of species removal on mean ego size in network along a mean Total Phosphorus gradient $(\mu \mathrm{g} / \mathrm{g})$ for taxon Nitzschia palea var. tenuirostris. Vertical lines indicate thresholds at 83 and 195 $\mu \mathrm{g} / \mathrm{g}$. Two-way ANOVA with replication follows immediately.

Analysis of Variance Table

Response: Differences

\begin{tabular}{|l|l|l|l|l|l|}
\hline & Df & Sum Sq & Mean Sq & F value & $\operatorname{Pr}(>\mathrm{F})$ \\
\hline Year & 9 & 23.180 & 2.57558 & 38.612 & $<2.2 \mathrm{e}-16^{* * *}$ \\
\hline TP & 2 & 6.069 & 3.03442 & 45.491 & $<2.2 \mathrm{e}-16 * * *$ \\
\hline Year:TP & 12 & 8.772 & 0.73103 & 10.959 & $<2.2 \mathrm{e}-16 * * *$ \\
\hline Residuals & 527 & 35.153 & 0.06670 & & \\
\hline
\end{tabular}

Signif. codes: 0 ‘***’ 0.001 '**’ 0.01 '*’ 0.05 '? 0.1 ' ' 1 


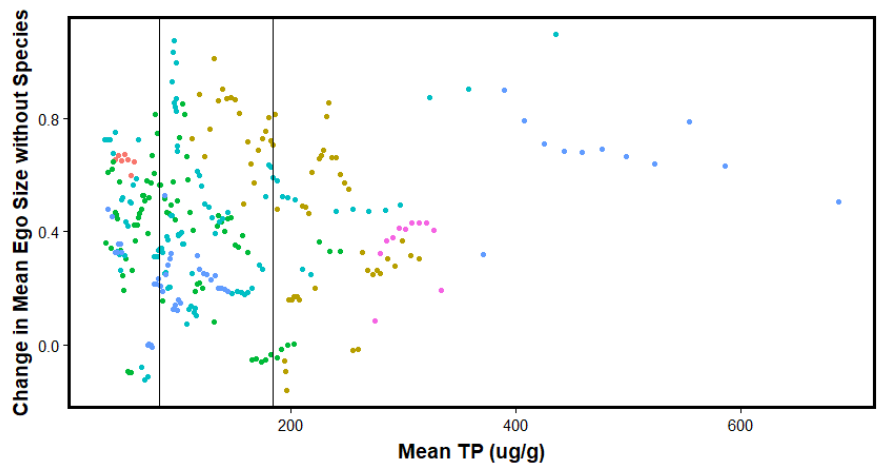

Years : $2011: 2012: 2014: 2015$

Figure B44. Plot of Effect of species removal on mean ego size in network along a mean Total Phosphorus gradient $(\mu \mathrm{g} / \mathrm{g})$ for taxon Pseudostaurosira brevistriata. Vertical lines indicate thresholds at 83 and 195 $\mu \mathrm{g} / \mathrm{g}$. Two-way ANOVA with replication follows immediately.

Analysis of Variance Table

Response: Differences

\begin{tabular}{|l|l|l|l|l|l|}
\hline & Df & Sum Sq & Mean Sq & F value & $\operatorname{Pr}(>\mathrm{F})$ \\
\hline Year & 5 & 1.3687 & 0.27375 & 5.7704 & $4.306 \mathrm{e}-05 * * *$ \\
\hline TP & 2 & 0.0710 & 0.03550 & 0.7483 & 0.4741 \\
\hline Year:TP & 5 & 4.5047 & 0.90095 & 18.9913 & $2.669 \mathrm{e}-16 * * *$ \\
\hline Residuals & 285 & 13.5204 & 0.04744 & & \\
\hline
\end{tabular}

Signif. codes: 0 ‘***’ 0.001 ‘** 0.01 '*’ 0.05 '? 0.1 ', 1 


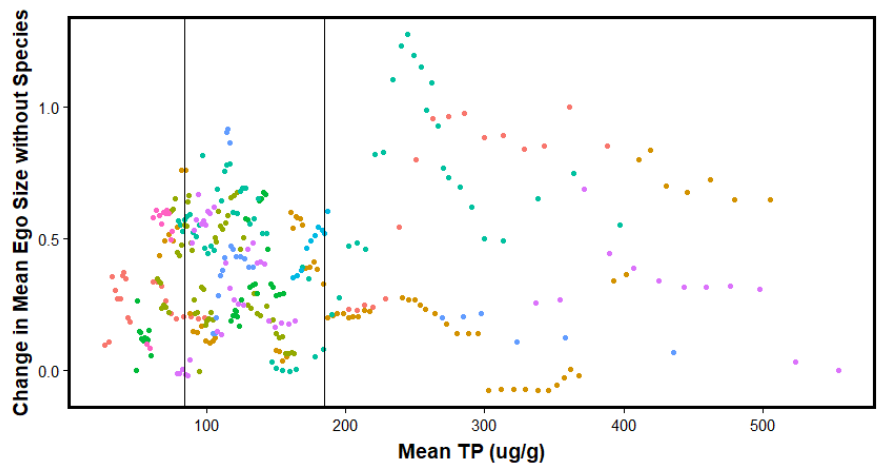

Years $: 2007: 2009: 2010: 2011: 2014 \cdot 2016$

Figure B45. Plot of Effect of species removal on mean ego size in network along a mean Total Phosphorus gradient $(\mu \mathrm{g} / \mathrm{g})$ for taxon Pinnularia microstauron. Vertical lines indicate thresholds at 83 and $195 \mu \mathrm{g} / \mathrm{g}$. Two-way ANOVA with replication follows immediately.

Analysis of Variance Table

Response: Differences

\begin{tabular}{|l|l|l|l|l|l|}
\hline & Df & Sum Sq & Mean Sq & F value & $\operatorname{Pr}(>\mathrm{F})$ \\
\hline Year & 8 & 4.0663 & 0.50829 & 10.8899 & $1.248 \mathrm{e}-13 * * *$ \\
\hline TP & 2 & 0.6473 & 0.32365 & 6.9341 & $0.001123 * *$ \\
\hline Year:TP & 10 & 3.8440 & 0.38440 & 8.2357 & $6.298 \mathrm{e}-12 * * *$ \\
\hline Residuals & 329 & 15.3561 & 0.04667 & & \\
\hline
\end{tabular}

Signif. codes: 0 ‘***’ 0.001 '**’ 0.01 '*’ 0.05 '? 0.1 ' ’ 1 


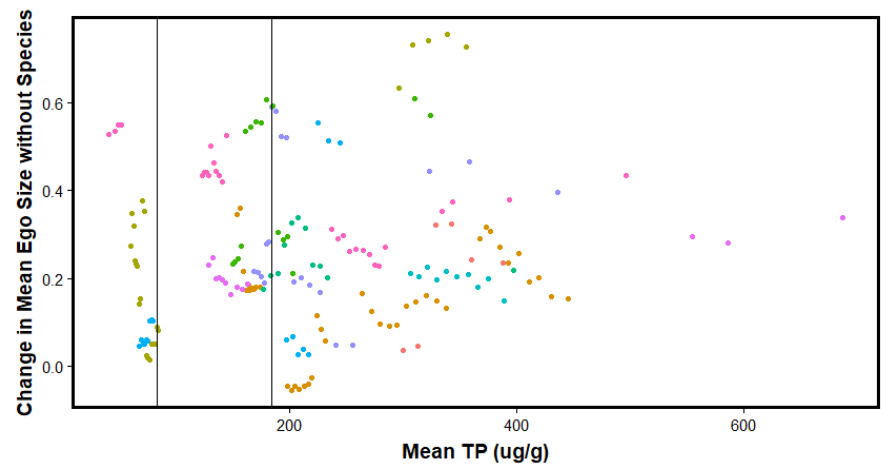

Years $: 2007: 2009: 2010: 2011: 2013: 2014: 2016$

Figure B46. Plot of Effect of species removal on mean ego size in network along a mean Total Phosphorus gradient $(\mu \mathrm{g} / \mathrm{g})$ for taxon Rhopalodia gibba. Vertical lines indicate thresholds at 83 and $195 \mu \mathrm{g} / \mathrm{g}$. Two-way ANOVA with replication follows immediately.

Analysis of Variance Table

Response: Differences

\begin{tabular}{|l|l|l|l|l|l|}
\hline & Df & Sum Sq & Mean Sq & F value & $\operatorname{Pr}(>\mathrm{F})$ \\
\hline Year & 9 & 1.77746 & 0.197496 & 14.5073 & $<2.2 \mathrm{e}-16 * * *$ \\
\hline TP & 2 & 0.25912 & 0.129559 & 9.5169 & $0.0001229 * * *$ \\
\hline Year:TP & 8 & 1.37732 & 0.172164 & 12.6466 & $4.495 \mathrm{e}-14 * * *$ \\
\hline Residuals & 164 & 2.23262 & 0.013614 & & \\
\hline
\end{tabular}

Signif. codes: 0 ‘***’ 0.001 '**’ 0.01 '*’ 0.05 '? 0.1 ' ' 1 


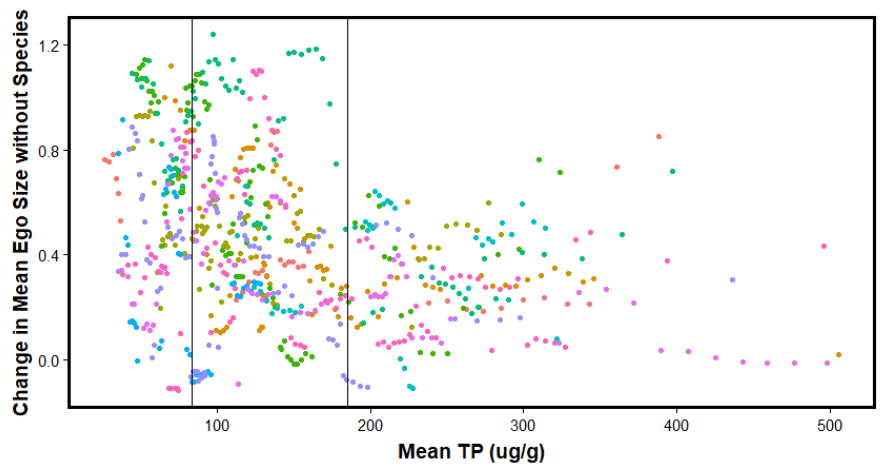

Years $: 2007: 2009: 2010: 2011: 2013: 2014: 2016$

Figure B47. Plot of Effect of species removal on mean ego size in network along a mean Total Phosphorus gradient $(\mu \mathrm{g} / \mathrm{g})$ for taxon Sellaphora laevissima. Vertical lines indicate thresholds at 83 and $195 \mu \mathrm{g} / \mathrm{g}$. Twoway ANOVA with replication follows immediately.

Analysis of Variance Table

Response: Differences

\begin{tabular}{|l|l|l|l|l|l|}
\hline & Df & Sum Sq & Mean Sq & F value & $\operatorname{Pr}(>\mathrm{F})$ \\
\hline Year & 9 & 12.048 & 1.3386 & 23.1457 & $<2.2 \mathrm{e}-16^{* * *}$ \\
\hline TP & 2 & 9.873 & 4.9366 & 85.3557 & $<2.2 \mathrm{e}-16 * * *$ \\
\hline Year:TP & 16 & 7.360 & 0.4600 & 7.9536 & $<2.2 \mathrm{e}-16 * * *$ \\
\hline Residuals & 679 & 39.270 & 0.0578 & & \\
\hline
\end{tabular}

Signif. codes: 0 ‘***’ 0.001 '**’ 0.01 '*’ 0.05 '? 0.1 ' ' 1 


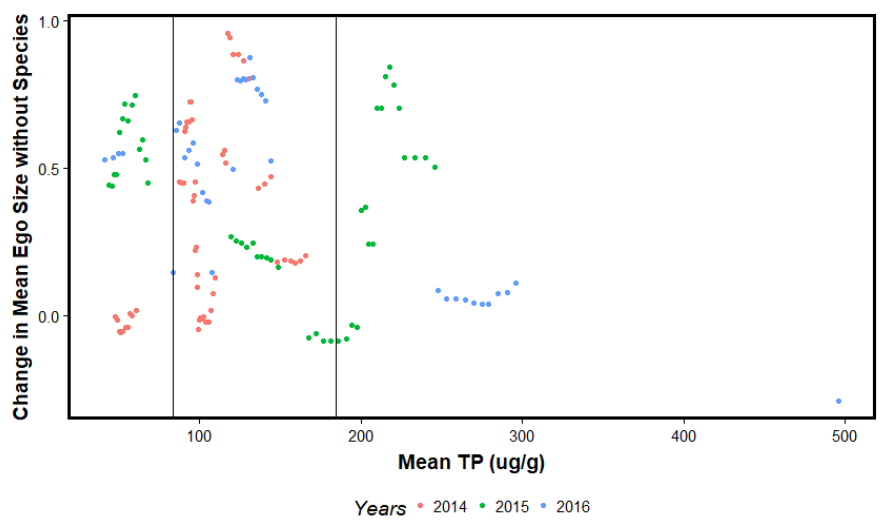

Figure B48. Plot of Effect of species removal on mean ego size in network along a mean Total Phosphorus gradient $(\mu \mathrm{g} / \mathrm{g})$ for taxon Sellaphora seminulum. Vertical lines indicate thresholds at 83 and $195 \mu \mathrm{g} / \mathrm{g}$. Two-way ANOVA with replication follows immediately.

Analysis of Variance Table

Response: Differences

\begin{tabular}{|l|l|l|l|l|l|}
\hline & Df & Sum Sq & Mean Sq & F value & $\operatorname{Pr}(>\mathrm{F})$ \\
\hline Year & 2 & 0.2326 & 0.11631 & 2.0495 & 0.132911 \\
\hline TP & 2 & 0.7989 & 0.39946 & 7.0385 & $0.001249 * *$ \\
\hline Year:TP & 3 & 4.4692 & 1.48973 & 26.2493 & $2.321 \mathrm{e}-13 * * *$ \\
\hline Residuals & 131 & 7.4347 & 0.05675 & & \\
\hline
\end{tabular}

Signif. codes: 0 ‘***’ 0.001 '**’ 0.01 '*’ 0.05 '? 0.1 ' ' 1 


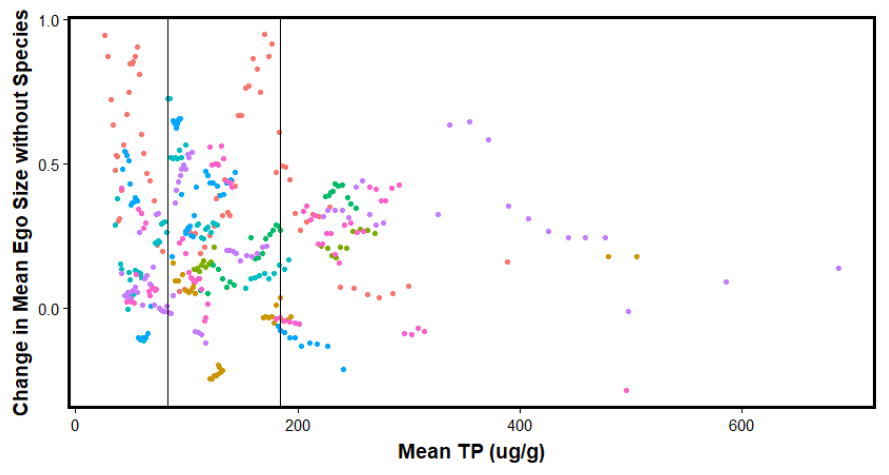

Years : $2007: 2009: 2012: 2014: 2015$

Figure B49. Plot of Effect of species removal on mean ego size in network along a mean Total Phosphorus gradient $(\mu \mathrm{g} / \mathrm{g})$ for taxon Sellaphora stroemii. Vertical lines indicate thresholds at 83 and $195 \mu \mathrm{g} / \mathrm{g}$. Twoway ANOVA with replication follows immediately.

Analysis of Variance Table

Response: Differences

\begin{tabular}{|l|l|l|l|l|l|}
\hline & Df & Sum Sq & Mean Sq & F value & $\operatorname{Pr}(>\mathrm{F})$ \\
\hline Year & 7 & 6.7920 & 0.97029 & 29.2879 & $<2.2 \mathrm{e}-16^{* * *}$ \\
\hline TP & 2 & 0.3494 & 0.17469 & 5.2729 & $0.005508 * *$ \\
\hline Year:TP & 11 & 4.3250 & 0.39318 & 11.8681 & $<2.2 \mathrm{e}-16 * * *$ \\
\hline Residuals & 383 & 12.6885 & 0.03313 & & \\
\hline
\end{tabular}

Signif. codes: 0 ‘***’ 0.001 '**’ 0.01 '*’ 0.05 '? 0.1 ' ' 1 


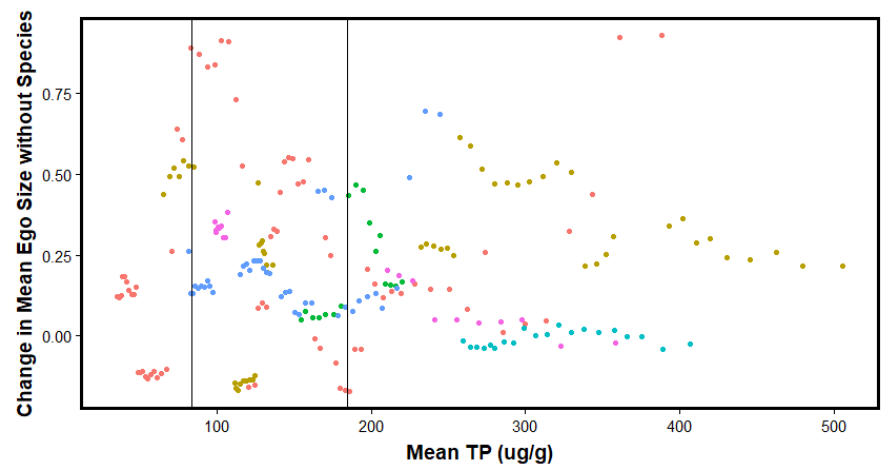

Years : ${ }_{2008}^{2007}: 2012: 2013$

Figure B50. Plot of Effect of species removal on mean ego size in network along a mean Total Phosphorus gradient $(\mu \mathrm{g} / \mathrm{g})$ for taxon Synedra filiformis var. exilis. Vertical lines indicate thresholds at 83 and $195 \mu \mathrm{g} / \mathrm{g}$. Two-way ANOVA with replication follows immediately.

Analysis of Variance Table

Response: Differences

\begin{tabular}{|l|l|l|l|l|l|}
\hline & Df & Sum Sq & Mean Sq & F value & $\operatorname{Pr}(>\mathrm{F})$ \\
\hline Year & 5 & 1.2251 & 0.24503 & 5.6116 & $7.027 \mathrm{e}-05 * * *$ \\
\hline TP & 2 & 0.1406 & 0.07030 & 1.6101 & 0.2023 \\
\hline Year:TP & 6 & 2.3823 & 0.39705 & 9.0932 & $7.464 \mathrm{e}-09 * * *$ \\
\hline Residuals & 212 & 9.2569 & 0.04366 & & \\
\hline
\end{tabular}

Signif. codes: 0 ‘***’ 0.001 '**’ 0.01 '*’ 0.05 '? 0.1 ' ' 1 


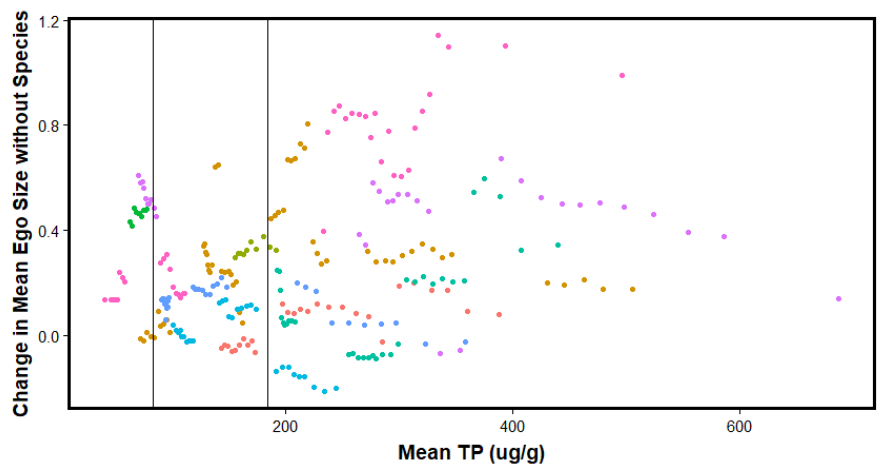

Years $: 2007: 2009: 2010: 2012: 2014 \cdot 2016$

Figure B51. Plot of Effect of species removal on mean ego size in network along a mean Total Phosphorus gradient $(\mu \mathrm{g} / \mathrm{g})$ for taxon Ulnaria delicatissima. Vertical lines indicate thresholds at 83 and $195 \mu \mathrm{g} / \mathrm{g}$. Twoway ANOVA with replication follows immediately.

Analysis of Variance Table

Response: Differences

\begin{tabular}{|l|l|l|l|l|l|}
\hline & Df & Sum Sq & Mean Sq & F value & $\operatorname{Pr}(>\mathrm{F})$ \\
\hline Year & 8 & 9.4955 & 1.18693 & 65.548 & $<2.2 \mathrm{e}-16 * * *$ \\
\hline TP & 2 & 1.1984 & 0.59918 & 33.090 & $1.828 \mathrm{e}-13 * * *$ \\
\hline Year:TP & 8 & 3.8509 & 0.48137 & 26.583 & $<2.2 \mathrm{e}-16 * * *$ \\
\hline Residuals & 248 & 4.4907 & 0.01811 & & \\
\hline
\end{tabular}

Signif. codes: 0 ‘***’ 0.001 '**’ 0.01 '*’ 0.05 '? 0.1 ' ' 1 
Appendix C: Species Frequency Relative to Network Mean TP-Plots and ANOVA

tables

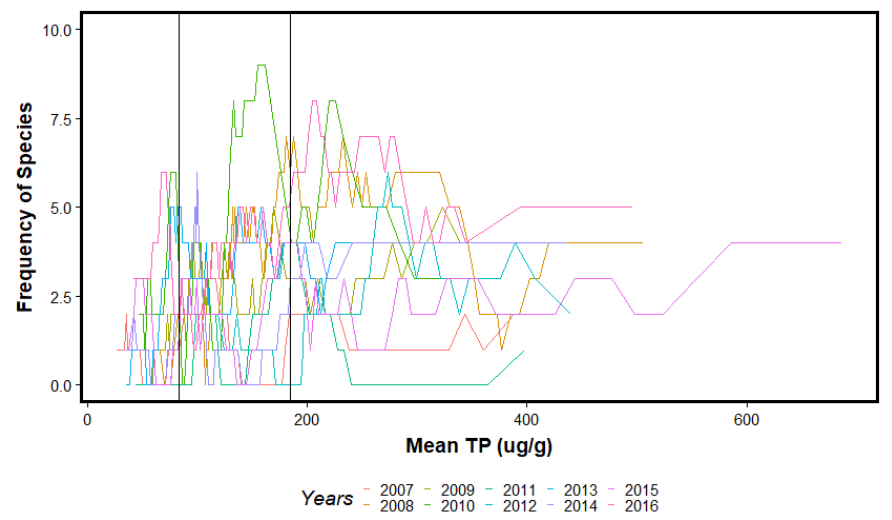

Figure C1. Plot of species frequency in network along a mean Total Phosphorus gradient $(\mu \mathrm{g} / \mathrm{g})$ for taxon Achnantidium minutissimum var. gracillima. Vertical lines indicate thresholds at 83 and $195 \mu \mathrm{g} / \mathrm{g}$. Twoway ANOVA with replication follows immediately.

Analysis of Variance Table

Response: ACMINGRA

\begin{tabular}{|l|l|l|l|l|l|}
\hline & Df & Sum Sq & Mean Sq & F value & $\operatorname{Pr}(>\mathrm{F})$ \\
\hline Year & 9 & 1255.32 & 139.480 & 75.4274 & $<2.2 \mathrm{e}-16 * * *$ \\
\hline TP & 2 & 375.61 & 187.807 & 101.5619 & $<2.2 \mathrm{e}-16 * * *$ \\
\hline Year:TP & 17 & 166.40 & 9.788 & 5.2934 & $2.706 \mathrm{e}-11 * * *$ \\
\hline Residuals & 888 & 1642.08 & 1.849 & & \\
\hline
\end{tabular}

Signif. codes: 0 '***’ 0.001 '**' 0.01 '*’ 0.05 ', 0.1 ' ’ 1 


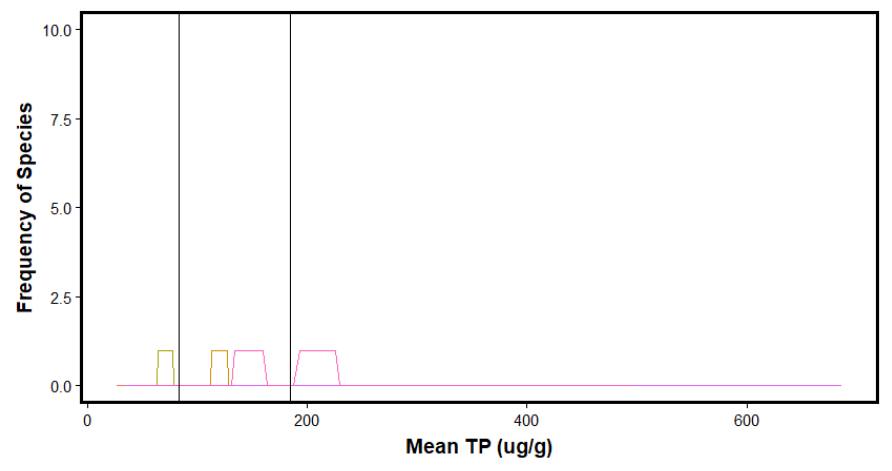

Years $-2007-2008-2010-2011-2013-2013-2015$

Figure C2. Plot of species frequency in network along a mean Total Phosphorus gradient $(\mu \mathrm{g} / \mathrm{g})$ for taxon Amphora ovalis. Vertical lines indicate thresholds at 83 and $195 \mu \mathrm{g} / \mathrm{g}$. Two-way ANOVA with replication follows immediately.

Analysis of Variance Table

Response: AMOVAOVA

\begin{tabular}{|l|l|l|l|l|l|}
\hline & Df & Sum Sq & Mean Sq & F value & $\operatorname{Pr}(>\mathrm{F})$ \\
\hline Year & 9 & 4.2869 & 0.47632 & 14.6799 & $<2 \mathrm{e}-16 * * *$ \\
\hline TP & 2 & 0.0820 & 0.04099 & 1.2633 & 0.2832 \\
\hline Year:TP & 17 & 5.0735 & 0.29844 & 9.1978 & $<2 \mathrm{e}-16 * * *$ \\
\hline Residuals & 888 & 28.8129 & 0.03245 & & \\
\hline
\end{tabular}

Signif. codes: 0 ‘***’ 0.001 '**’ 0.01 '*’ 0.05 '? 0.1 ' ' 1 


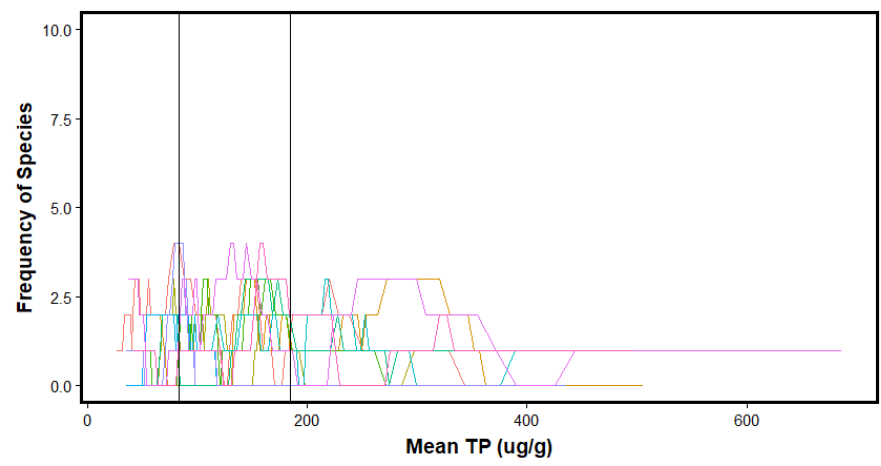

Years $-2007-2009-2011-2013-2015$

Figure C3. Plot of species frequency in network along a mean Total Phosphorus gradient $(\mu \mathrm{g} / \mathrm{g})$ for taxon Amphora sulcata. Vertical lines indicate thresholds at 83 and $195 \mu \mathrm{g} / \mathrm{g}$. Two-way ANOVA with replication follows immediately.

Analysis of Variance Table

Response: AMSULSUL

\begin{tabular}{|l|l|l|l|l|l|}
\hline & Df & Sum Sq & Mean Sq & F value & $\operatorname{Pr}(>\mathrm{F})$ \\
\hline Year & 9 & 85.06 & 9.4515 & 11.5629 & $<2.2 \mathrm{e}-16 * * *$ \\
\hline TP & 2 & 27.79 & 13.8941 & 16.9980 & $5.697 \mathrm{e}-08 * * *$ \\
\hline Year:TP & 17 & 118.33 & 6.9608 & 8.5158 & $<2.2 \mathrm{e}-16 * * *$ \\
\hline Residuals & 888 & 725.85 & 0.8174 & & \\
\hline
\end{tabular}

Signif. codes: 0 “***’ 0.001 '**’ 0.01 '*’ 0.05 '? 0.1 ', 1 


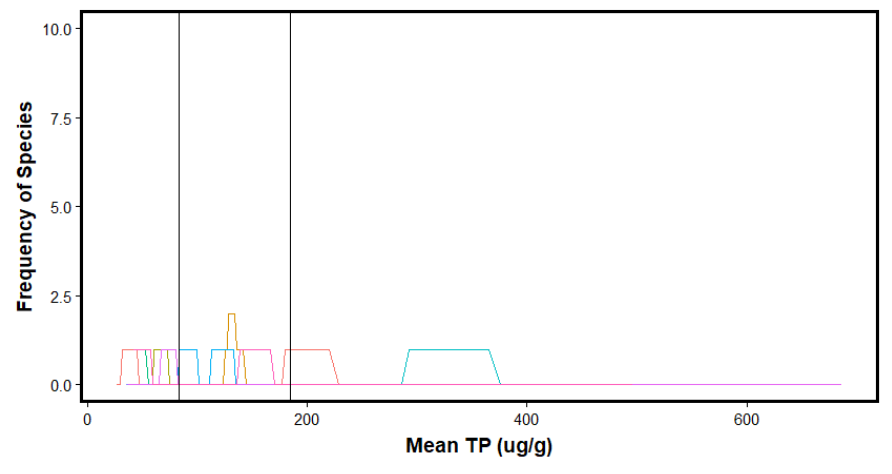

Years $-2007-2008-2010-2011-2013-2013-2015$

Figure C4. Plot of species frequency in network along a mean Total Phosphorus gradient $(\mu \mathrm{g} / \mathrm{g})$ for taxon Aulacoseira cf. distans. Vertical lines indicate thresholds at 83 and $195 \mu \mathrm{g} / \mathrm{g}$. Two-way ANOVA with replication follows immediately.

Analysis of Variance Table

Response: AUCFDIST

\begin{tabular}{|l|l|l|l|l|l|}
\hline & Df & Sum Sq & Mean Sq & F value & $\operatorname{Pr}(>\mathrm{F})$ \\
\hline Year & 9 & 6.760 & 0.75113 & 7.7915 & $4.185 \mathrm{e}-11 * * *$ \\
\hline TP & 2 & 2.576 & 1.28778 & 13.3582 & $1.924 \mathrm{e}-06 * * *$ \\
\hline Year:TP & 17 & 15.863 & 0.93313 & 9.6795 & $<2.2 \mathrm{e}-16 * * *$ \\
\hline Residuals & 888 & 85.606 & 0.09640 & & \\
\hline
\end{tabular}

Signif. codes: 0 ‘***’ 0.001 '**’ 0.01 '*’ 0.05 '? 0.1 ' ' 1 


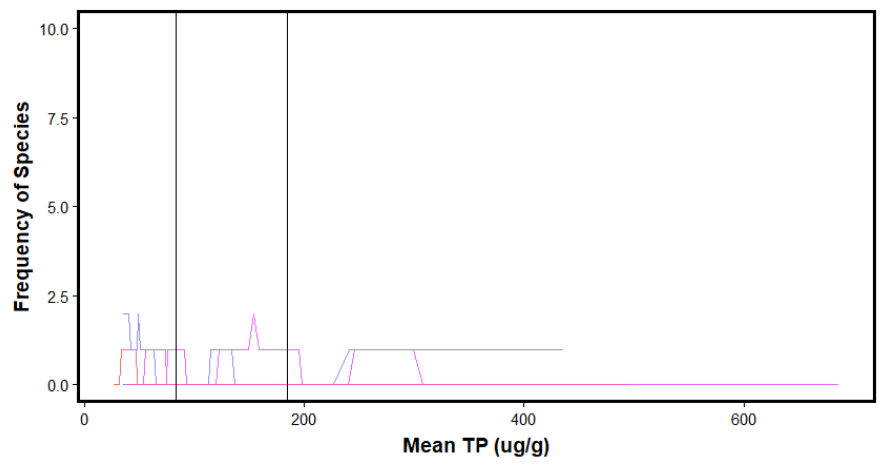

Years $-2007-2008-2010-2011-2013-2013-2015$

Figure C5. Plot of species frequency in network along a mean Total Phosphorus gradient $(\mu \mathrm{g} / \mathrm{g})$ for taxon Aulacoseira cf. granulata. Vertical lines indicate thresholds at 83 and $195 \mu \mathrm{g} / \mathrm{g}$. Two-way ANOVA with replication follows immediately.

Analysis of Variance Table

\section{Response: AUCFGRAN}

\begin{tabular}{|l|l|l|l|l|l|}
\hline & Df & Sum Sq & Mean Sq & F value & $\operatorname{Pr}(>\mathrm{F})$ \\
\hline Year & 9 & 30.092 & 3.3436 & 55.421 & $<2.2 \mathrm{e}-16 * * *$ \\
\hline TP & 2 & 2.652 & 1.3258 & 21.976 & $4.836 \mathrm{e}-10 * * *$ \\
\hline Year:TP & 17 & 11.994 & 0.7055 & 11.694 & $<2.2 \mathrm{e}-16 * * *$ \\
\hline Residuals & 888 & 53.574 & 0.0603 & & \\
\hline
\end{tabular}

Signif. codes: 0 ‘***’ 0.001 '**’ 0.01 '*’ 0.05 '? 0.1 ' ' 1 


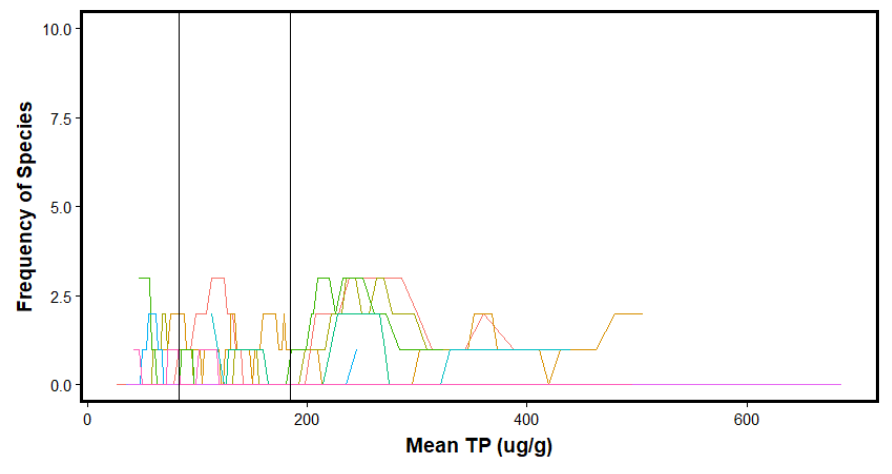

Years $-2007-2008-2010-2011-2013-2013-2015$

Figure C6. Plot of species frequency in network along a mean Total Phosphorus gradient $(\mu \mathrm{g} / \mathrm{g})$ for taxon Brachysira brebissonii. Vertical lines indicate thresholds at 83 and $195 \mu \mathrm{g} / \mathrm{g}$. Two-way ANOVA with replication follows immediately.

Analysis of Variance Table

Response: BRBREBRE

\begin{tabular}{|l|l|l|l|l|l|}
\hline & Df & Sum Sq & Mean Sq & F value & $\operatorname{Pr}(>\mathrm{F})$ \\
\hline Year & 9 & 123.476 & 13.7195 & 41.995 & $<2.2 \mathrm{e}-16 * * *$ \\
\hline TP & 2 & 15.535 & 7.7673 & 23.776 & $8.736 \mathrm{e}-11 * * *$ \\
\hline Year:TP & 17 & 115.780 & 6.8106 & 20.847 & $<2.2 \mathrm{e}-16 * * *$ \\
\hline Residuals & 888 & 290.101 & 0.3267 & & \\
\hline
\end{tabular}

Signif. codes: 0 “***’ 0.001 '**, 0.01 '*’ 0.05 '? 0.1 ' ' 1 


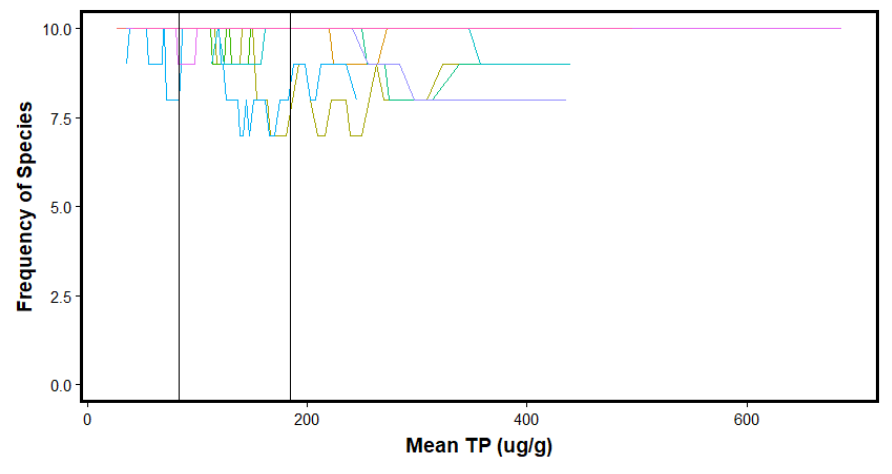

Years $-2007-2008-2010-2011-2013-2013-2015$

Figure C7. Plot of species frequency in network along a mean Total Phosphorus gradient $(\mu \mathrm{g} / \mathrm{g})$ for taxon Brachysira microcephala. Vertical lines indicate thresholds at 83 and $195 \mu \mathrm{g} / \mathrm{g}$. Two-way ANOVA with replication follows immediately.

Analysis of Variance Table

Response: BRMICMIC

\begin{tabular}{|l|l|l|l|l|l|}
\hline & Df & Sum Sq & Mean Sq & F value & $\operatorname{Pr}(>\mathrm{F})$ \\
\hline Year & 9 & 100.708 & 11.1898 & 50.910 & $<2.2 \mathrm{e}-16 * * *$ \\
\hline TP & 2 & 16.355 & 8.1775 & 37.205 & $3.044 \mathrm{e}-16 * * *$ \\
\hline Year:TP & 17 & 58.954 & 3.4679 & 15.778 & $<2.2 \mathrm{e}-16 * * *$ \\
\hline Residuals & 888 & 195.180 & 0.2198 & & \\
\hline
\end{tabular}

Signif. codes: 0 ‘***’ 0.001 '**’ 0.01 '*’ 0.05 '? 0.1 ' ' 1 


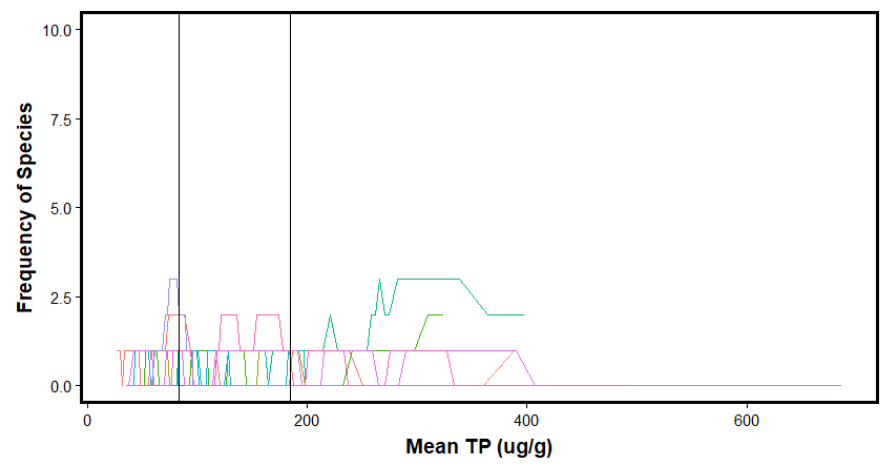

Years $-2007-2008-2010-2011-2013-2013-2015$

Figure C8. Plot of species frequency in network along a mean Total Phosphorus gradient $(\mu \mathrm{g} / \mathrm{g})$ for taxon Caponea caribbea. Vertical lines indicate thresholds at 83 and $195 \mu \mathrm{g} / \mathrm{g}$. Two-way ANOVA with replication follows immediately.

Analysis of Variance Table

\section{Response: CPCARCAR}

\begin{tabular}{|l|l|l|l|l|l|}
\hline & Df & Sum Sq & Mean Sq & F value & $\operatorname{Pr}(>\mathrm{F})$ \\
\hline Year & 9 & 44.555 & 4.9505 & 18.5238 & $<2 \mathrm{e}-16 * * *$ \\
\hline TP & 2 & 0.024 & 0.0120 & 0.0451 & 0.9559 \\
\hline Year:TP & 17 & 72.630 & 4.2723 & 15.9860 & $<2 \mathrm{e}-16 * * *$ \\
\hline Residuals & 888 & 237.321 & 0.2673 & & \\
\hline
\end{tabular}

Signif. codes: 0 ‘***’ 0.001 '**’ 0.01 '*’ 0.05 '? 0.1 ' ' 1 


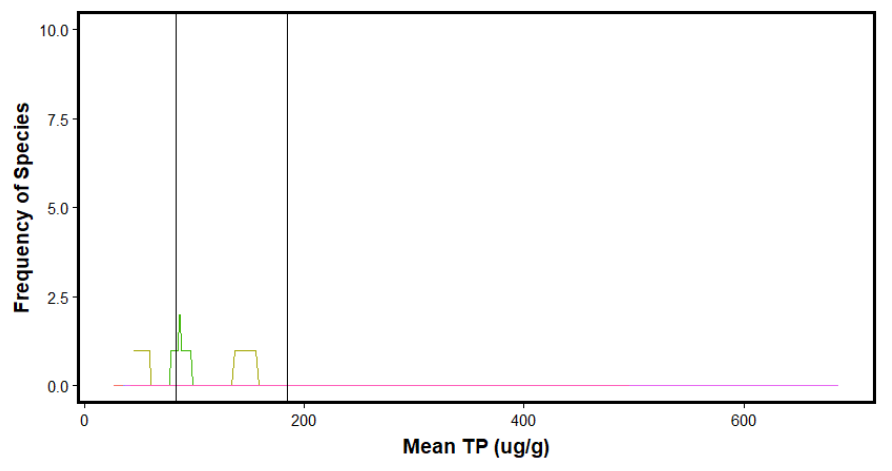

Years $-2007-2008-2010-2011-2013-2013-2015$

Figure C9. Plot of species frequency in network along a mean Total Phosphorus gradient $(\mu \mathrm{g} / \mathrm{g})$ for taxon Craticula accomodiformis. Vertical lines indicate thresholds at 83 and $195 \mu \mathrm{g} / \mathrm{g}$. Two-way ANOVA with replication follows immediately.

Analysis of Variance Table

\section{Response: CRACCACC}

\begin{tabular}{|l|l|l|l|l|l|}
\hline & Df & Sum Sq & Mean Sq & F value & $\operatorname{Pr}(>\mathrm{F})$ \\
\hline Year & 9 & 6.258 & 0.69538 & 18.6005 & $<2.2 \mathrm{e}-16 * * *$ \\
\hline TP & 2 & 0.472 & 0.23580 & 6.3074 & $0.001905 * *$ \\
\hline Year:TP & 17 & 2.328 & 0.13691 & 3.6622 & $8.122 \mathrm{e}-07 * * *$ \\
\hline Residuals & 888 & 33.198 & 0.03738 & & \\
\hline
\end{tabular}

Signif. codes: 0 “***’ 0.001 '**, 0.01 '*’ 0.05 '? 0.1 ' ' 1 


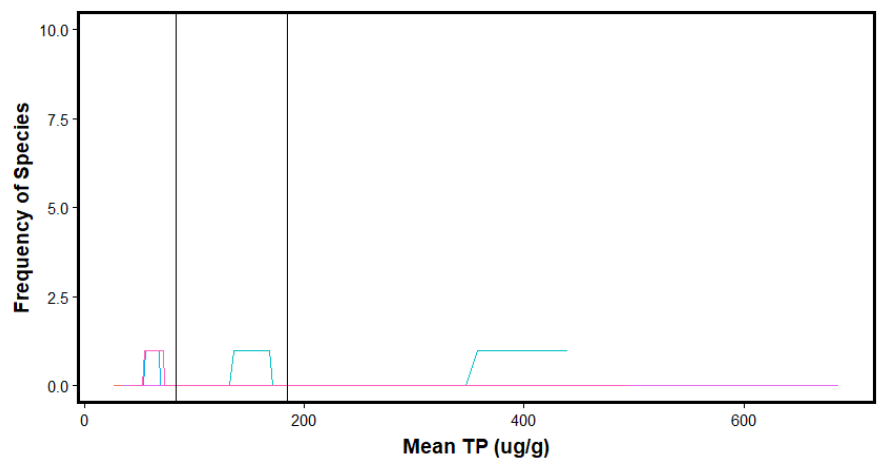

Years $-2007-2008-2010-2011-2013-2013-2015$

Figure C10. Plot of species frequency in network along a mean Total Phosphorus gradient $(\mu \mathrm{g} / \mathrm{g})$ for taxon Cyclotella iris. Vertical lines indicate thresholds at 83 and $195 \mu \mathrm{g} / \mathrm{g}$. Two-way ANOVA with replication follows immediately.

Analysis of Variance Table

\section{Response: CYIRIIRI}

\begin{tabular}{|l|l|l|l|l|l|}
\hline & Df & Sum Sq & Mean Sq & F value & $\operatorname{Pr}(>\mathrm{F})$ \\
\hline Year & 9 & 4.3288 & 0.48098 & 18.168 & $<2.2 \mathrm{e}-16 * * *$ \\
\hline TP & 2 & 1.3488 & 0.67438 & 25.474 & $1.748 \mathrm{e}-11 * * *$ \\
\hline Year:TP & 17 & 5.4007 & 0.31769 & 12.000 & $<2.2 \mathrm{e}-16 * * *$ \\
\hline Residuals & 888 & 23.5084 & 0.02647 & & \\
\hline
\end{tabular}

Signif. codes: 0 “***’ 0.001 '**, 0.01 '*’ 0.05 '? 0.1 ' ' 1 


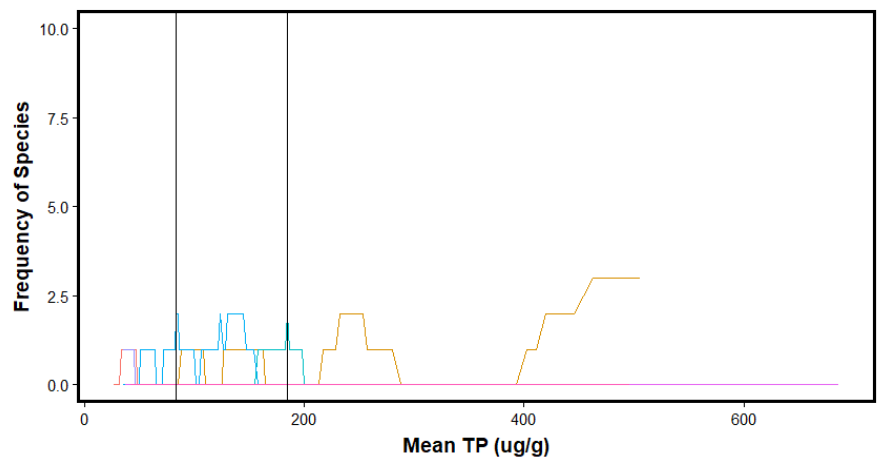

Years $-2007-2008-2010-2011-2013-2013-2015$

Figure C11. Plot of species frequency in network along a mean Total Phosphorus gradient $(\mu \mathrm{g} / \mathrm{g})$ for taxon Diploneis puella. Vertical lines indicate thresholds at 83 and $195 \mu \mathrm{g} / \mathrm{g}$. Two-way ANOVA with replication follows immediately.

Analysis of Variance Table

Response: DIPUEPUE

\begin{tabular}{|l|l|l|l|l|l|}
\hline & Df & Sum Sq & Mean Sq & F value & $\operatorname{Pr}(>\mathrm{F})$ \\
\hline Year & 9 & 64.420 & 7.1578 & 58.1636 & $<2 \mathrm{e}-16 * * *$ \\
\hline TP & 2 & 0.424 & 0.2119 & 1.7219 & 0.1793 \\
\hline Year:TP & 17 & 17.256 & 1.0151 & 8.2483 & $<2 \mathrm{e}-16 * * *$ \\
\hline Residuals & 888 & 109.280 & 0.1231 & & \\
\hline
\end{tabular}

Signif. codes: 0 “***’ 0.001 '**, 0.01 '*’ 0.05 '? 0.1 ' ' 1 


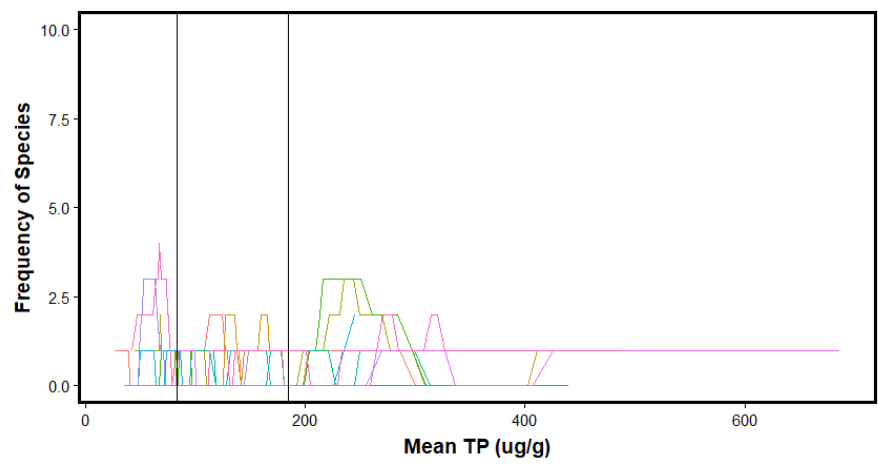

Years $-2007-2008-2010-2011-2013-2014-2015$

Figure C12. Plot of species frequency in network along a mean Total Phosphorus gradient $(\mu \mathrm{g} / \mathrm{g})$ for taxon Encyonopsis egsp01. Vertical lines indicate thresholds at 83 and $195 \mu \mathrm{g} / \mathrm{g}$. Two-way ANOVA with replication follows immediately.

Analysis of Variance Table

Response: ECEGSP01

\begin{tabular}{|l|l|l|l|l|l|}
\hline & Df & Sum Sq & Mean Sq & F value & $\operatorname{Pr}(>\mathrm{F})$ \\
\hline Year & 9 & 51.466 & 5.7184 & 16.897 & $<2.2 \mathrm{e}-16 * * *$ \\
\hline TP & 2 & 12.989 & 6.4945 & 19.190 & $6.934 \mathrm{e}-09 * * *$ \\
\hline Year:TP & 17 & 108.039 & 6.3552 & 18.779 & $<2.2 \mathrm{e}-16 * * *$ \\
\hline Residuals & 888 & 300.527 & 0.3384 & & \\
\hline
\end{tabular}

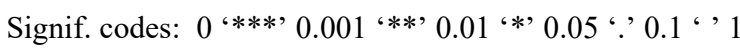




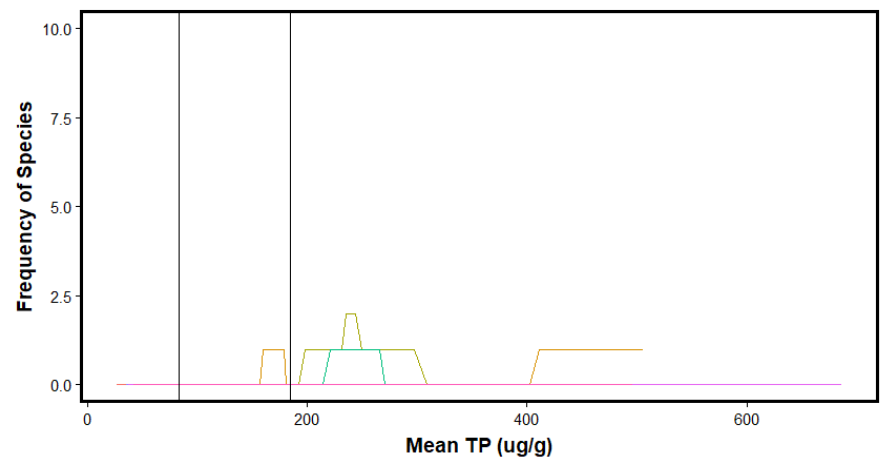

Years $-2007-2008-2010-2011-2013-2013-2015$

Figure C13. Plot of species frequency in network along a mean Total Phosphorus gradient $(\mu \mathrm{g} / \mathrm{g})$ for taxon Encyonopsis floridana. Vertical lines indicate thresholds at 83 and $195 \mu \mathrm{g} / \mathrm{g}$. Two-way ANOVA with replication follows immediately.

Analysis of Variance Table

Response: ECFLOFLO

\begin{tabular}{|l|l|l|l|l|l|}
\hline & Df & Sum Sq & Mean Sq & F value & $\operatorname{Pr}(>\mathrm{F})$ \\
\hline Year & 9 & 5.7606 & 0.64006 & 20.002 & $<2.2 \mathrm{e}-16 * * *$ \\
\hline TP & 2 & 2.7114 & 1.35570 & 42.365 & $<2.2 \mathrm{e}-16 * * *$ \\
\hline Year:TP & 17 & 13.7031 & 0.80606 & 25.189 & $<2.2 \mathrm{e}-16 * * *$ \\
\hline Residuals & 888 & 28.4160 & 0.03200 & & \\
\hline
\end{tabular}

$---$

Signif. codes: 0 “***’ 0.001 '**, 0.01 '*’ 0.05 '? 0.1 ' ' 1 


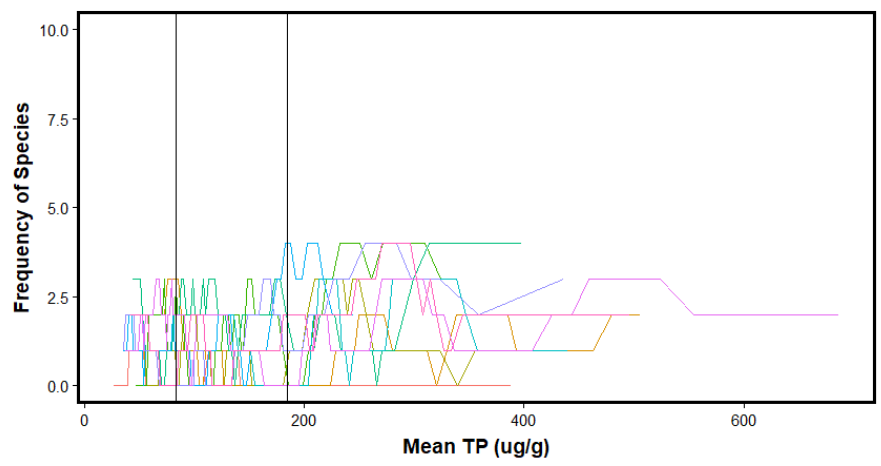

Years $-2007-2008-2010-2011-2013-2014-2015$

Figure C14. Plot of species frequency in network along a mean Total Phosphorus gradient $(\mu \mathrm{g} / \mathrm{g})$ for taxon Encyonopsis subminuta. Vertical lines indicate thresholds at 83 and $195 \mu \mathrm{g} / \mathrm{g}$. Two-way ANOVA with replication follows immediately.

Analysis of Variance Table

Response: ECSUBSUB

\begin{tabular}{|l|l|l|l|l|l|}
\hline & Df & Sum Sq & Mean Sq & F value & $\operatorname{Pr}(>\mathrm{F})$ \\
\hline Year & 9 & 146.24 & 16.249 & 22.416 & $<2.2 \mathrm{e}-16^{* * *}$ \\
\hline TP & 2 & 102.80 & 51.400 & 70.906 & $<2.2 \mathrm{e}-16 * * *$ \\
\hline Year:TP & 17 & 126.52 & 7.442 & 10.266 & $<2.2 \mathrm{e}-16 * * *$ \\
\hline Residuals & 888 & 643.71 & 0.725 & & \\
\hline
\end{tabular}

Signif. codes: 0 “***’ 0.001 '**’ 0.01 '*’ 0.05 '? 0.1 ', 1 


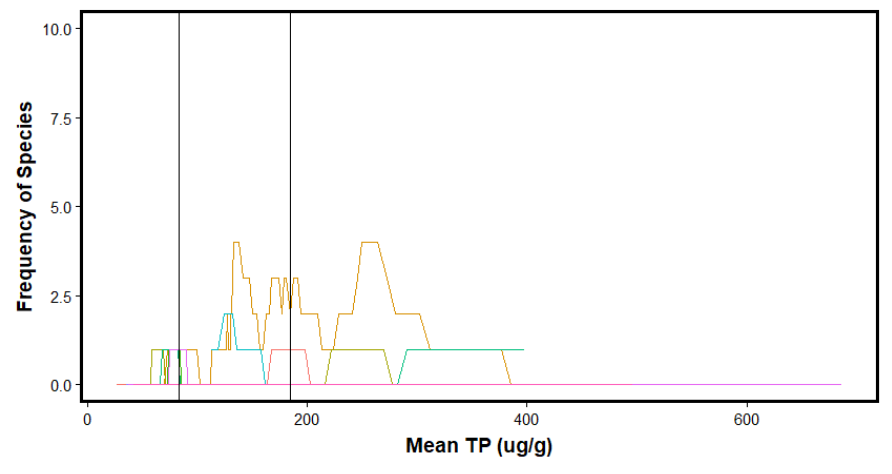

Years $-2007-2008-2010-2011-2013-2013-2015$

Figure C15. Plot of species frequency in network along a mean Total Phosphorus gradient $(\mu \mathrm{g} / \mathrm{g})$ for taxon Encyonema cf. evergladianum. Vertical lines indicate thresholds at 83 and $195 \mu \mathrm{g} / \mathrm{g}$. Two-way ANOVA with replication follows immediately.

Analysis of Variance Table

Response: ENCFEVER

\begin{tabular}{|l|l|l|l|l|l|}
\hline & Df & Sum Sq & Mean Sq & F value & $\operatorname{Pr}(>\mathrm{F})$ \\
\hline Year & 9 & 198.944 & 22.1049 & 104.4734 & $<2.2 \mathrm{e}-16 * * *$ \\
\hline TP & 2 & 1.237 & 0.6184 & 2.9229 & 0.0543 \\
\hline Year:TP & 17 & 23.594 & 1.3879 & 6.5595 & $7.023 \mathrm{e}-15 * * *$ \\
\hline Residuals & 888 & 187.887 & 0.2116 & & \\
\hline
\end{tabular}

Signif. codes: 0 “***’ 0.001 '**, 0.01 '*’ 0.05 '? 0.1 ' ' 1 


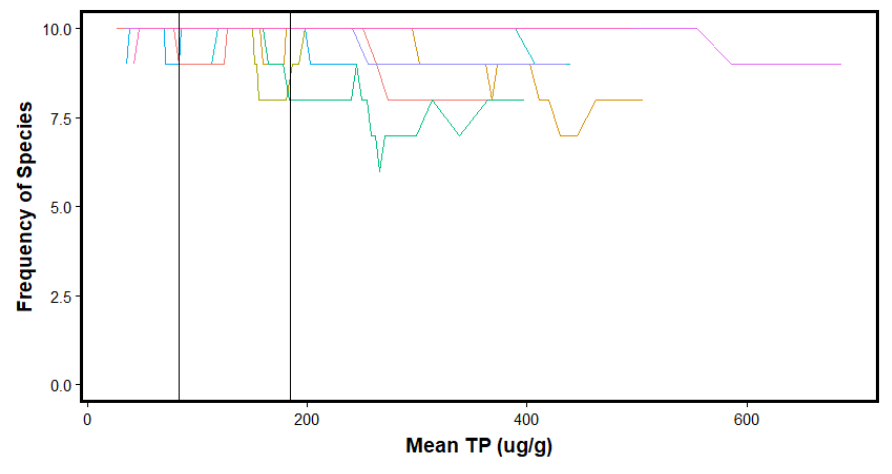

Years $-2007-2008-2010-2011-2013-2014-2015$

Figure C16. Plot of species frequency in network along a mean Total Phosphorus gradient $(\mu \mathrm{g} / \mathrm{g})$ for taxon Encyonema evergladianum. Vertical lines indicate thresholds at 83 and $195 \mu \mathrm{g} / \mathrm{g}$. Two-way ANOVA with replication follows immediately.

Analysis of Variance Table

Response: ENEVEEVE

\begin{tabular}{|l|l|l|l|l|l|}
\hline & Df & Sum Sq & Mean Sq & F value & $\operatorname{Pr}(>\mathrm{F})$ \\
\hline Year & 9 & 49.516 & 5.5017 & 36.892 & $<2.2 \mathrm{e}-16 * * *$ \\
\hline TP & 2 & 28.292 & 14.1462 & 94.858 & $<2.2 \mathrm{e}-16 * * *$ \\
\hline Year:TP & 17 & 82.245 & 4.8379 & 32.441 & $<2.2 \mathrm{e}-16 * * *$ \\
\hline Residuals & 888 & 132.427 & 0.1491 & & \\
\hline
\end{tabular}

Signif. codes: 0 “***’ 0.001 '**’ 0.01 '*’ 0.05 '? 0.1 ' ' 1 


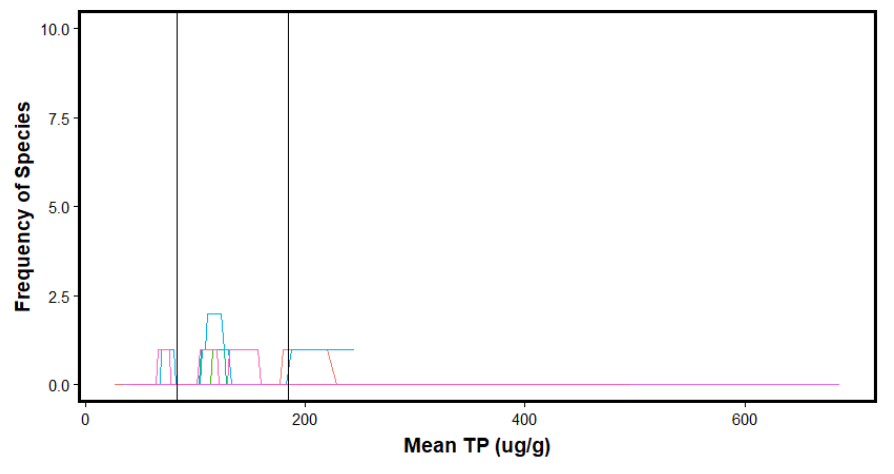

Years $-2007-2008-2010-2011-2013-2013-2015$

Figure C17. Plot of species frequency in network along a mean Total Phosphorus gradient $(\mu \mathrm{g} / \mathrm{g})$ for taxon Encyonema ftsp04. Vertical lines indicate thresholds at 83 and $195 \mu \mathrm{g} / \mathrm{g}$. Two-way ANOVA with replication follows immediately.

Analysis of Variance Table

\section{Response: ENFTSP04}

\begin{tabular}{|l|l|l|l|l|l|}
\hline & Df & Sum Sq & Mean Sq & F value & $\operatorname{Pr}(>\mathrm{F})$ \\
\hline Year & 9 & 20.570 & 2.28561 & 29.3411 & $<2.2 \mathrm{e}-16 * * *$ \\
\hline TP & 2 & 1.553 & 0.77627 & 9.9652 & $5.248 \mathrm{e}-05 * * *$ \\
\hline Year:TP & 17 & 11.799 & 0.69404 & 8.9097 & $<2.2 \mathrm{e}-16 * * *$ \\
\hline Residuals & 888 & 69.173 & 0.07790 & & \\
\hline
\end{tabular}

Signif. codes: 0 “***’ 0.001 '**, 0.01 '*’ 0.05 '? 0.1 ' ' 1 


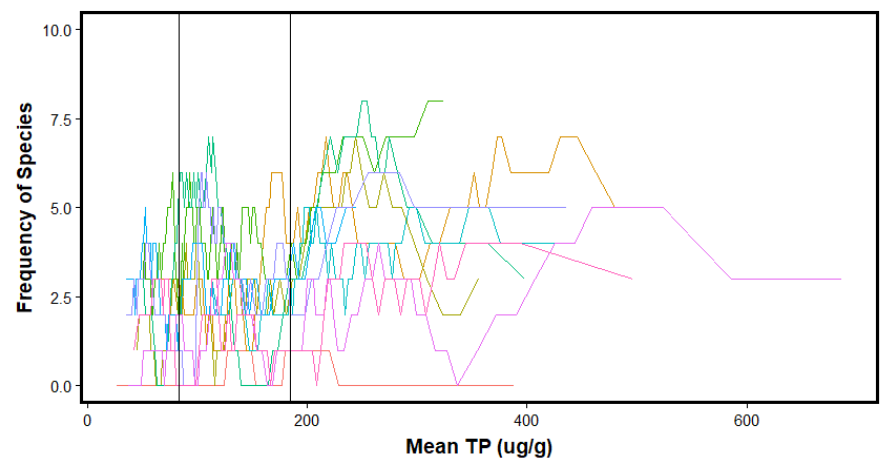

Years $-2007-2008-2010-2011-2013-2013-2015$

Figure C18. Plot of species frequency in network along a mean Total Phosphorus gradient $(\mu \mathrm{g} / \mathrm{g})$ for taxon Encyonema silesiacum var. elegans. Vertical lines indicate thresholds at 83 and $195 \mu \mathrm{g} / \mathrm{g}$. Two-way ANOVA with replication follows immediately.

Analysis of Variance Table

\section{Response: ENSILELE}

\begin{tabular}{|l|l|l|l|l|l|}
\hline & Df & Sum Sq & Mean Sq & F value & $\operatorname{Pr}(>\mathrm{F})$ \\
\hline Year & 9 & 1099.01 & 122.112 & 85.2147 & $<2.2 \mathrm{e}-16 * * *$ \\
\hline TP & 2 & 536.81 & 268.405 & 187.3032 & $<2.2 \mathrm{e}-16 * * *$ \\
\hline Year:TP & 17 & 130.89 & 7.700 & 5.3731 & $1.615 \mathrm{e}-11 * * *$ \\
\hline Residuals & 888 & 1272.50 & 1.433 & & \\
\hline
\end{tabular}

$---$

Signif. codes: 0 ‘***’ 0.001 '**’ 0.01 '*’ 0.05 '? 0.1 ' ' 1 


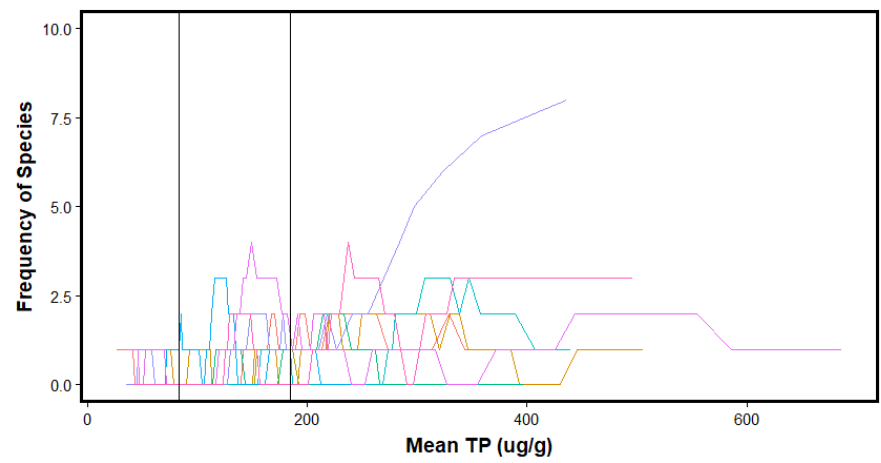

Years $-2007-2008-2010-2011-2013-2014-2015$

Figure C19. Plot of species frequency in network along a mean Total Phosphorus gradient $(\mu \mathrm{g} / \mathrm{g})$ for taxon Encyonema silesiacum. Vertical lines indicate thresholds at 83 and $195 \mu \mathrm{g} / \mathrm{g}$. Two-way ANOVA with replication follows immediately.

Analysis of Variance Table

Response: ENSILSIL

\begin{tabular}{|l|l|l|l|l|l|}
\hline & Df & Sum Sq & Mean Sq & F value & $\operatorname{Pr}(>\mathrm{F})$ \\
\hline Year & 9 & 93.05 & 10.339 & 19.875 & $<2.2 \mathrm{e}-16^{* * *}$ \\
\hline TP & 2 & 87.97 & 43.987 & 84.558 & $<2.2 \mathrm{e}-16 * * *$ \\
\hline Year:TP & 17 & 108.87 & 6.404 & 12.311 & $<2.2 \mathrm{e}-16 * * *$ \\
\hline Residuals & 888 & 461.93 & 0.520 & & \\
\hline
\end{tabular}

Signif. codes: 0 “***’ 0.001 ‘** 0.01 '*’ 0.05 '? 0.1 ', 1 


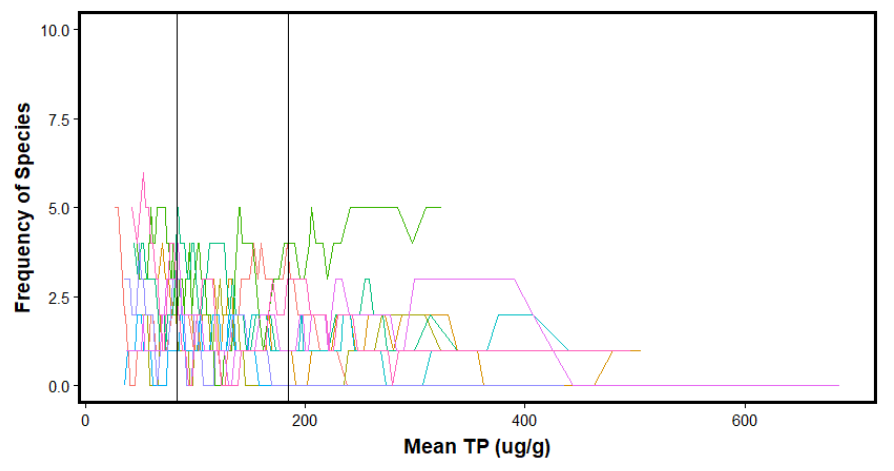

Years $-2007-2008-2010-2011-2012-2014-2015$

Figure C20. Plot of species frequency in network along a mean Total Phosphorus gradient $(\mu \mathrm{g} / \mathrm{g})$ for taxon Encyonema sjsp03. Vertical lines indicate thresholds at 83 and $195 \mu \mathrm{g} / \mathrm{g}$. Two-way ANOVA with replication follows immediately.

Analysis of Variance Table

Response: ENSJSP03

\begin{tabular}{|l|l|l|l|l|l|}
\hline & Df & Sum Sq & Mean Sq & F value & $\operatorname{Pr}(>\mathrm{F})$ \\
\hline Year & 9 & 415.18 & 46.131 & 53.772 & $<2.2 \mathrm{e}-16^{* * *}$ \\
\hline TP & 2 & 81.54 & 40.770 & 47.523 & $<2.2 \mathrm{e}-16 * * *$ \\
\hline Year:TP & 17 & 198.42 & 11.672 & 13.605 & $<2.2 \mathrm{e}-16 * * *$ \\
\hline Residuals & 888 & 761.82 & 0.858 & & \\
\hline
\end{tabular}

Signif. codes: 0 “***’ 0.001 '**’ 0.01 '*’ 0.05 '? 0.1 ' ' 1 


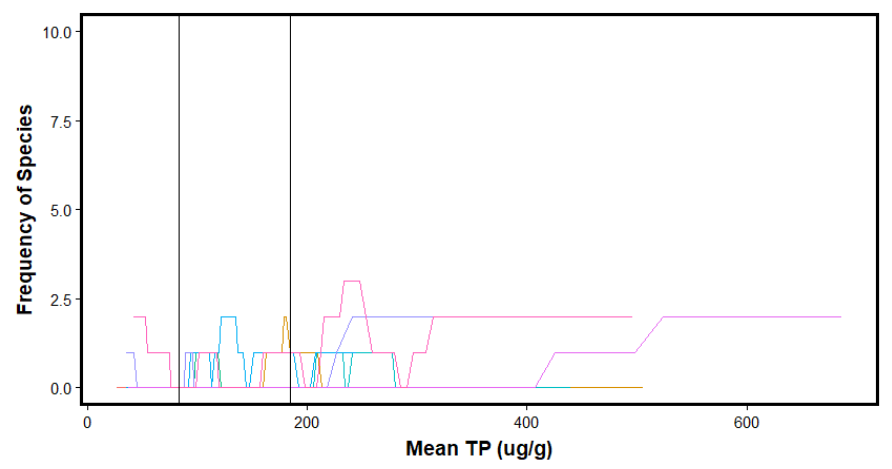

Years $-2007-2008-2010-2011-2013-2014-2015$

Figure C21. Plot of species frequency in network along a mean Total Phosphorus gradient ( $\mu \mathrm{g} / \mathrm{g})$ for taxon Eunotia egsp01. Vertical lines indicate thresholds at 83 and $195 \mu \mathrm{g} / \mathrm{g}$. Two-way ANOVA with replication follows immediately.

Analysis of Variance Table

Response: EUEGSP01

\begin{tabular}{|l|l|l|l|l|l|}
\hline & Df & Sum Sq & Mean Sq & F value & $\operatorname{Pr}(>\mathrm{F})$ \\
\hline Year & 9 & 68.399 & 7.5999 & 45.697 & $<2.2 \mathrm{e}-16 * * *$ \\
\hline TP & 2 & 11.813 & 5.9067 & 35.516 & $1.45 \mathrm{e}-15 * * *$ \\
\hline Year:TP & 17 & 43.416 & 2.5539 & 15.356 & $<2.2 \mathrm{e}-16 * * *$ \\
\hline Residuals & 888 & 147.683 & 0.1663 & & \\
\hline
\end{tabular}

Signif. codes: 0 ‘***’ 0.001 '**’ 0.01 '*’ 0.05 '? 0.1 ' ' 1 


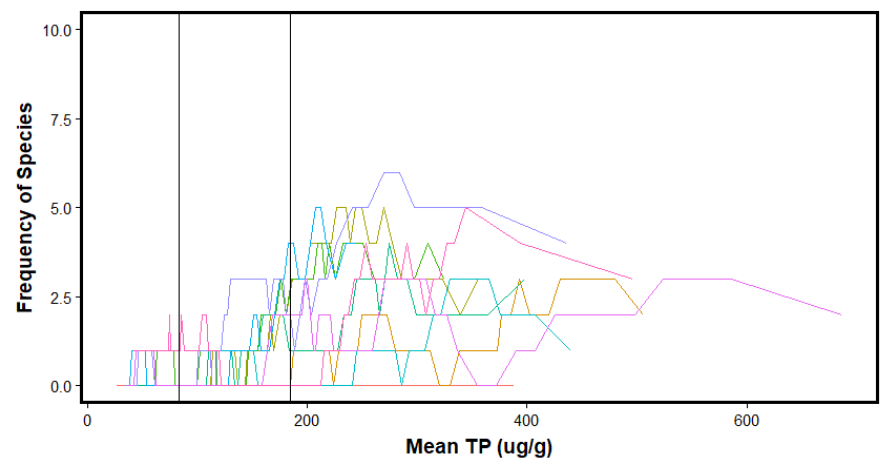

Years $-2007-2008-2010-2011-2013-2013-2015$

Figure C22. Plot of species frequency in network along a mean Total Phosphorus gradient $(\mu \mathrm{g} / \mathrm{g})$ for taxon Eunotia flexuosa. Vertical lines indicate thresholds at 83 and $195 \mu \mathrm{g} / \mathrm{g}$. Two-way ANOVA with replication follows immediately.

Analysis of Variance Table

Response: EUFLEFLE

\begin{tabular}{|l|l|l|l|l|l|}
\hline & Df & Sum Sq & Mean Sq & F value & $\operatorname{Pr}(>\mathrm{F})$ \\
\hline Year & 9 & 115.73 & 12.859 & 22.166 & $<2.2 \mathrm{e}-16 * * *$ \\
\hline TP & 2 & 587.47 & 293.735 & 506.337 & $<2.2 \mathrm{e}-16 * * *$ \\
\hline Year:TP & 17 & 218.31 & 12.842 & 22.137 & $<2.2 \mathrm{e}-16 * * *$ \\
\hline Residuals & 888 & 515.15 & 0.580 & & \\
\hline
\end{tabular}

Signif. codes: 0 ‘***’ 0.001 '**’ 0.01 '*’ 0.05 '? 0.1 ' ' 1 


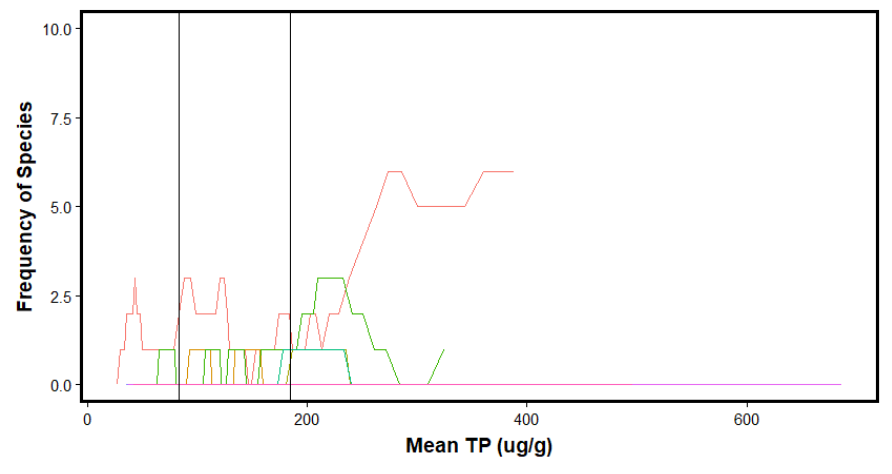

Years $-2007-2008-2010-2011-2013-2014-2015$

Figure C23. Plot of species frequency in network along a mean Total Phosphorus gradient $(\mu \mathrm{g} / \mathrm{g})$ for taxon Eunotia formica. Vertical lines indicate thresholds at 83 and $195 \mu \mathrm{g} / \mathrm{g}$. Two-way ANOVA with replication follows immediately.

Analysis of Variance Table

Response: EUFORFOR

\begin{tabular}{|l|l|l|l|l|l|}
\hline & Df & Sum Sq & Mean Sq & F value & $\operatorname{Pr}(>\mathrm{F})$ \\
\hline Year & 9 & 283.616 & 31.5129 & 161.298 & $<2.2 \mathrm{e}-16 * * *$ \\
\hline TP & 2 & 18.464 & 9.2319 & 47.253 & $<2.2 \mathrm{e}-16^{* * *}$ \\
\hline Year:TP & 17 & 76.427 & 4.4957 & 23.011 & $<2.2 \mathrm{e}-16 * * *$ \\
\hline Residuals & 888 & 173.489 & 0.1954 & & \\
\hline
\end{tabular}

Signif. codes: 0 “***’ 0.001 '**’ 0.01 '*’ 0.05 '? 0.1 ' ' 1 


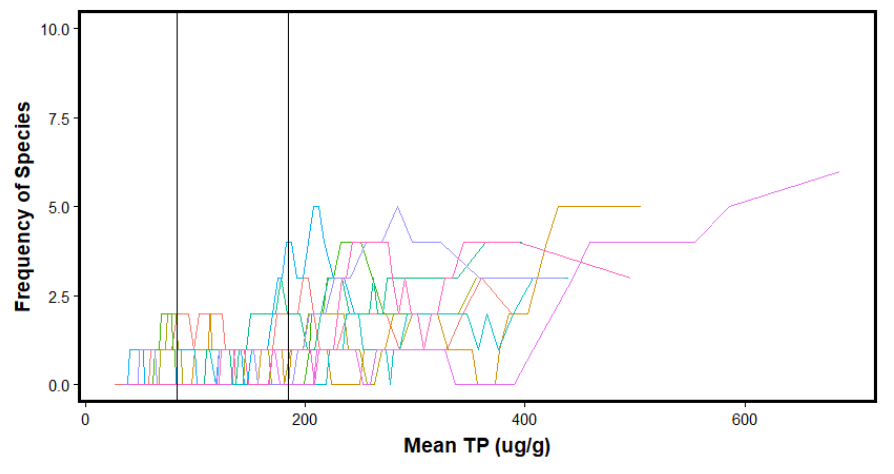

Years $-2007-2008-2010-2011-2013-2015-2016$

Figure C24. Plot of species frequency in network along a mean Total Phosphorus gradient $(\mu \mathrm{g} / \mathrm{g})$ for taxon Eunotiea naegelii. Vertical lines indicate thresholds at 83 and $195 \mu \mathrm{g} / \mathrm{g}$. Two-way ANOVA with replication follows immediately.

Analysis of Variance Table

Response: EUNAENAE

\begin{tabular}{|l|l|l|l|l|l|}
\hline & Df & Sum Sq & Mean Sq & F value & $\operatorname{Pr}(>\mathrm{F})$ \\
\hline Year & 9 & 36.84 & 4.094 & 6.2179 & $1.529 \mathrm{e}-08 * * *$ \\
\hline TP & 2 & 406.16 & 203.082 & 308.4497 & $<2.2 \mathrm{e}-16 * * *$ \\
\hline Year:TP & 17 & 105.72 & 6.219 & 9.4451 & $<2.2 \mathrm{e}-16 * * *$ \\
\hline Residuals & 888 & 584.66 & 0.658 & & \\
\hline
\end{tabular}

Signif. codes: 0 “***’ 0.001 '**, 0.01 '*’ 0.05 '? 0.1 ' ' 1 


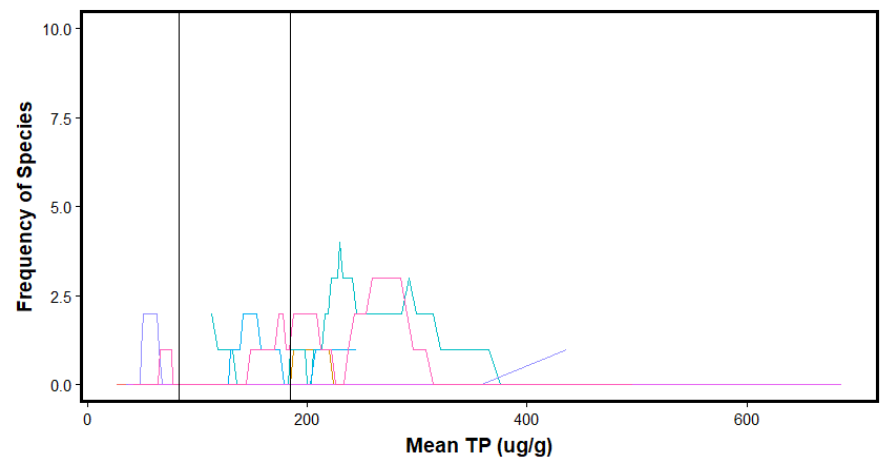

Years $-2007-2008-2010-2011-2013-2013-2015$

Figure C25. Plot of species frequency in network along a mean Total Phosphorus gradient $(\mu \mathrm{g} / \mathrm{g})$ for taxon Fragilaria cf. tenera. Vertical lines indicate thresholds at 83 and $195 \mu \mathrm{g} / \mathrm{g}$. Two-way ANOVA with replication follows immediately.

Analysis of Variance Table

Response: FACFTENE

\begin{tabular}{|l|l|l|l|l|l|}
\hline & Df & Sum Sq & Mean Sq & F value & $\operatorname{Pr}(>\mathrm{F})$ \\
\hline Year & 9 & 116.076 & 12.8973 & 68.217 & $<2.2 \mathrm{e}-16 * * *$ \\
\hline TP & 2 & 13.155 & 6.5775 & 34.790 & $2.841 \mathrm{e}-15 * * *$ \\
\hline Year:TP & 17 & 48.408 & 2.8475 & 15.061 & $<2.2 \mathrm{e}-16 * * *$ \\
\hline Residuals & 888 & 167.886 & 0.1891 & & \\
\hline
\end{tabular}

Signif. codes: 0 “***’ 0.001 '**, 0.01 '*’ 0.05 '? 0.1 ' ' 1 


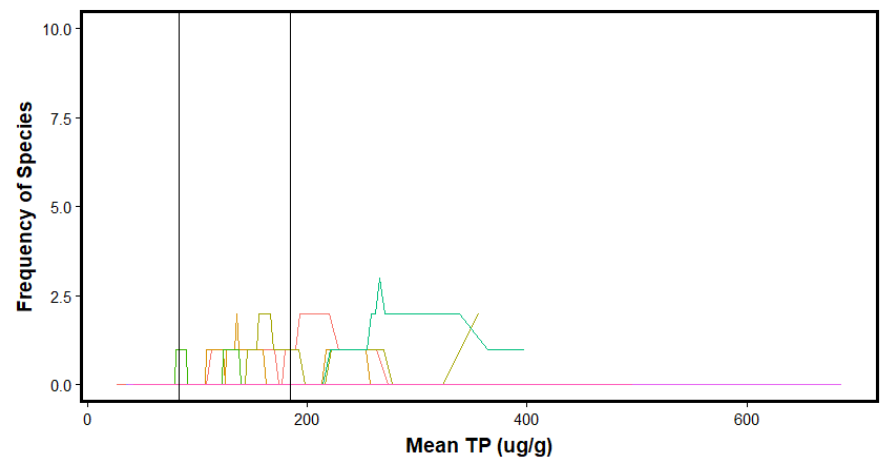

Years $-2007-2008-2010-2011-2013-2013-2015$

Figure C26. Plot of species frequency in network along a mean Total Phosphorus gradient $(\mu \mathrm{g} / \mathrm{g})$ for taxon Fragilaria ftsp16. Vertical lines indicate thresholds at 83 and $195 \mu \mathrm{g} / \mathrm{g}$. Two-way ANOVA with replication follows immediately.

Analysis of Variance Table

Response: FAFTSP16

\begin{tabular}{|l|l|l|l|l|l|}
\hline & Df & Sum Sq & Mean Sq & F value & $\operatorname{Pr}(>\mathrm{F})$ \\
\hline Year & 9 & 33.912 & 3.7680 & 33.101 & $<2.2 \mathrm{e}-16 * * *$ \\
\hline TP & 2 & 8.571 & 4.2854 & 37.647 & $<2.2 \mathrm{e}-16 * * *$ \\
\hline Year:TP & 17 & 40.461 & 2.3801 & 20.909 & $<2.2 \mathrm{e}-16 * * *$ \\
\hline Residuals & 888 & 101.082 & 0.1138 & & \\
\hline
\end{tabular}

Signif. codes: 0 “***’ 0.001 '**, 0.01 '*’ 0.05 '? 0.1 ' ' 1 


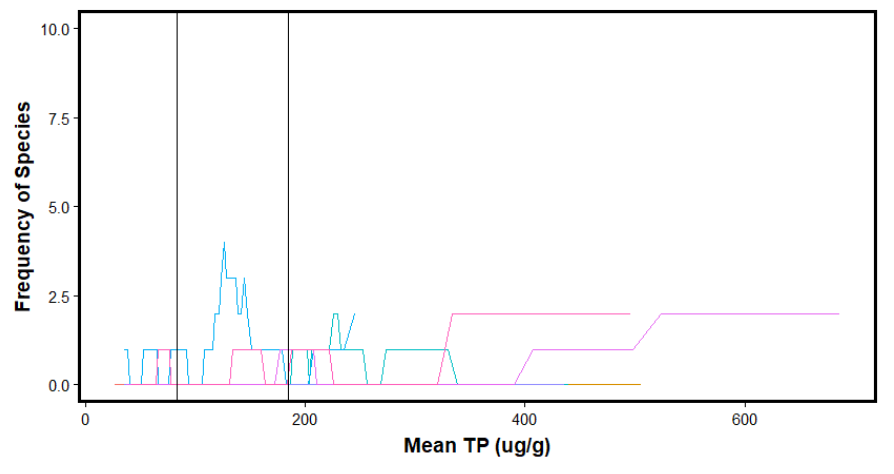

Years $-2007-2008-2010-2011-2013-2013-2015$

Figure C27. Plot of species frequency in network along a mean Total Phosphorus gradient $(\mu \mathrm{g} / \mathrm{g})$ for taxon Fragilariforma virescens var. capitata. Vertical lines indicate thresholds at 83 and $195 \mu \mathrm{g} / \mathrm{g}$. Two-way ANOVA with replication follows immediately.

Analysis of Variance Table

Response: FFVIRCAP

\begin{tabular}{|l|l|l|l|l|l|}
\hline & Df & Sum Sq & Mean Sq & F value & $\operatorname{Pr}(>\mathrm{F})$ \\
\hline Year & 9 & 80.479 & 8.9422 & 60.3826 & $<2.2 \mathrm{e}-16 * * *$ \\
\hline TP & 2 & 4.731 & 2.3653 & 15.9719 & $1.532 \mathrm{e}-07 * * *$ \\
\hline Year:TP & 17 & 19.162 & 1.1272 & 7.6114 & $<2.2 \mathrm{e}-16 * * *$ \\
\hline Residuals & 888 & 131.506 & 0.1481 & & \\
\hline
\end{tabular}

Signif. codes: 0 ‘***’ 0.001 '**’ 0.01 '*’ 0.05 '? 0.1 ' ' 1 


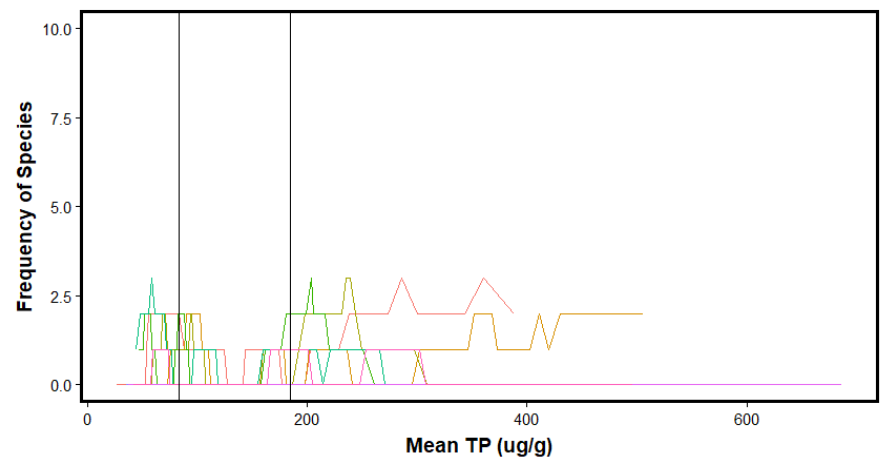

Years $-2007-2008-2010-2011-2013-2013-2015$

Figure C28. Plot of species frequency in network along a mean Total Phosphorus gradient $(\mu \mathrm{g} / \mathrm{g})$ for taxon Frustulia crassinervia. Vertical lines indicate thresholds at 83 and $195 \mu \mathrm{g} / \mathrm{g}$. Two-way ANOVA with replication follows immediately.

Analysis of Variance Table

Response: FRCRACRA

\begin{tabular}{|l|l|l|l|l|l|}
\hline & Df & Sum Sq & Mean Sq & F value & $\operatorname{Pr}(>\mathrm{F})$ \\
\hline Year & 9 & 112.616 & 12.5129 & 44.3500 & $<2.2 \mathrm{e}-16 * * *$ \\
\hline TP & 2 & 19.702 & 9.8510 & 34.9150 & $2.531 \mathrm{e}-15 * * *$ \\
\hline Year:TP & 17 & 31.260 & 1.8388 & 6.5175 & $9.252 \mathrm{e}-15 * * *$ \\
\hline Residuals & 888 & 250.541 & 0.2821 & & \\
\hline
\end{tabular}

$---$

Signif. codes: 0 ‘***’ 0.001 '**’ 0.01 '*’ 0.05 '? 0.1 ' ' 1 


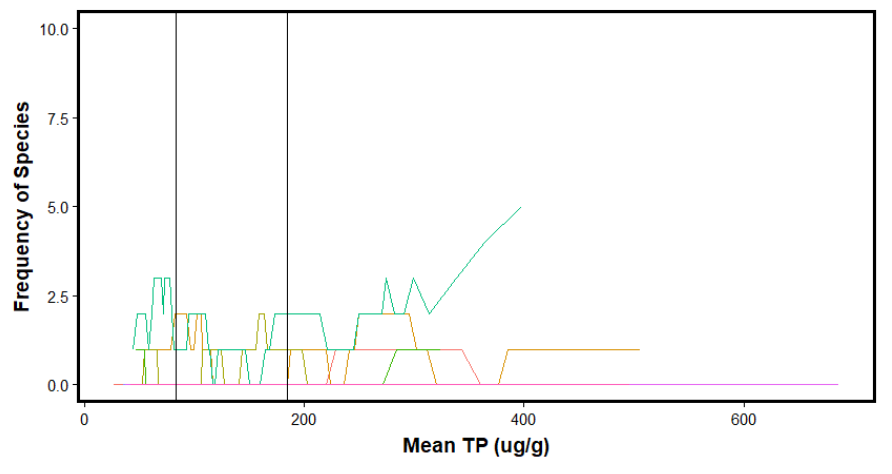

Years $-2007-2008-2010-2011-2013-2013-2015$

Figure C29. Plot of species frequency in network along a mean Total Phosphorus gradient $(\mu \mathrm{g} / \mathrm{g})$ for taxon Gomphonema affine. Vertical lines indicate thresholds at 83 and $195 \mu \mathrm{g} / \mathrm{g}$. Two-way ANOVA with replication follows immediately.

Analysis of Variance Table

Response: GOAFFAFF

\begin{tabular}{|l|l|l|l|l|l|}
\hline & Df & Sum Sq & Mean Sq & F value & $\operatorname{Pr}(>\mathrm{F})$ \\
\hline Year & 9 & 220.008 & 24.4454 & 159.887 & $<2.2 \mathrm{e}-16 * * *$ \\
\hline TP & 2 & 5.153 & 2.5763 & 16.851 & $6.565 \mathrm{e}-08 * * *$ \\
\hline Year:TP & 17 & 27.490 & 1.6171 & 10.577 & $<2.2 \mathrm{e}-16 * * *$ \\
\hline Residuals & 888 & 135.767 & 0.1529 & & \\
\hline
\end{tabular}

---

Signif. codes: 0 ‘***’ 0.001 '**’ 0.01 '*’ 0.05 '? 0.1 “ ' 1 


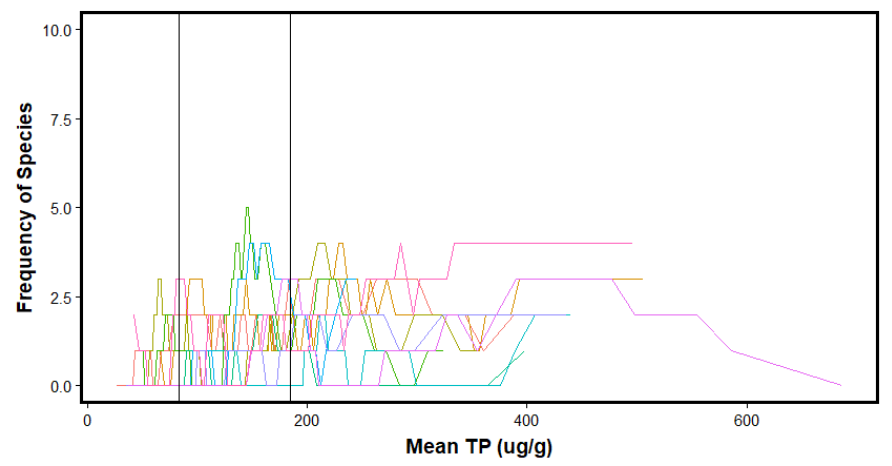

Years $-2007-2008-2010-2011-2013-2013-2015$

Figure C30. Plot of species frequency in network along a mean Total Phosphorus gradient $(\mu \mathrm{g} / \mathrm{g})$ for taxon Gomphonema cf. vibrioides. Vertical lines indicate thresholds at 83 and $195 \mu \mathrm{g} / \mathrm{g}$. Two-way ANOVA with replication follows immediately.

Analysis of Variance Table

\section{Response: GOCFVIBR}

\begin{tabular}{|l|l|l|l|l|l|}
\hline & Df & Sum Sq & Mean Sq & F value & $\operatorname{Pr}(>\mathrm{F})$ \\
\hline Year & 9 & 234.33 & 26.037 & 37.2771 & $<2.2 \mathrm{e}-16^{* * *}$ \\
\hline TP & 2 & 184.17 & 92.087 & 131.8413 & $<2.2 \mathrm{e}-16 * * *$ \\
\hline Year:TP & 17 & 92.38 & 5.434 & 7.7798 & $<2.2 \mathrm{e}-16 * * *$ \\
\hline Residuals & 888 & 620.24 & 0.698 & & \\
\hline
\end{tabular}

Signif. codes: 0 “***’ 0.001 '**, 0.01 '*’ 0.05 '? 0.1 ' ' 1 


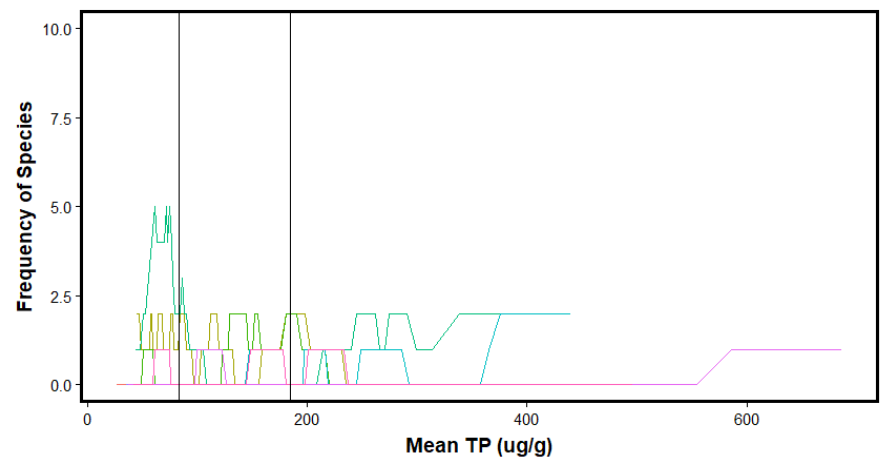

Years $-2007-2008-2010-2011-2013-2013-2015$

Figure C31. Plot of species frequency in network along a mean Total Phosphorus gradient $(\mu \mathrm{g} / \mathrm{g})$ for taxon Gomphonema gracile. Vertical lines indicate thresholds at 83 and $195 \mu \mathrm{g} / \mathrm{g}$. Two-way ANOVA with replication follows immediately.

Analysis of Variance Table

\section{Response: GOGRAGRA}

\begin{tabular}{|l|l|l|l|l|l|}
\hline & Df & Sum Sq & Mean Sq & F value & $\operatorname{Pr}(>\mathrm{F})$ \\
\hline Year & 9 & 174.883 & 19.4315 & 80.129 & $<2.2 \mathrm{e}-16 * * *$ \\
\hline TP & 2 & 10.322 & 5.1609 & 21.282 & $9.375 \mathrm{e}-10 * * *$ \\
\hline Year:TP & 17 & 97.391 & 5.7289 & 23.624 & $<2.2 \mathrm{e}-16 * * *$ \\
\hline Residuals & 888 & 215.341 & 0.2425 & & \\
\hline
\end{tabular}

Signif. codes: 0 “***’ 0.001 '**’ 0.01 '*’ 0.05 '? 0.1 ', 1 


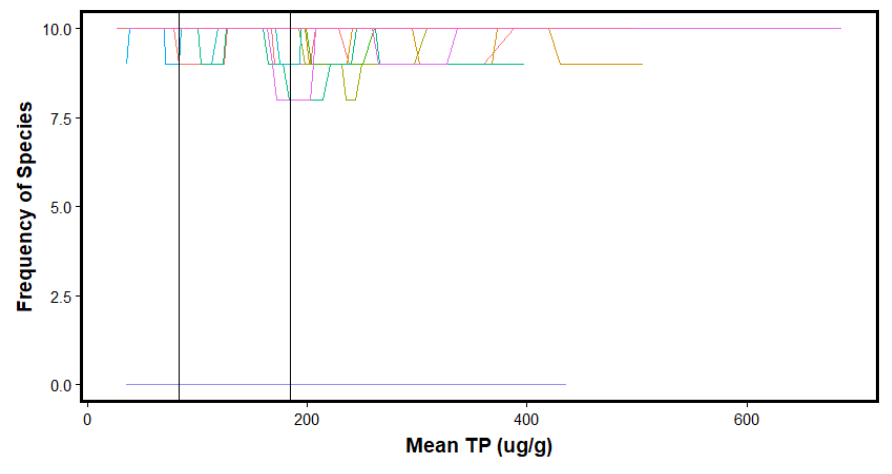

Years $-2007-2008-2010-2011-2013-2013-2015$

Figure C32. Plot of species frequency in network along a mean Total Phosphorus gradient $(\mu \mathrm{g} / \mathrm{g})$ for taxon Mastogloia calcarea. Vertical lines indicate thresholds at 83 and $195 \mu \mathrm{g} / \mathrm{g}$. Two-way ANOVA with replication follows immediately.

Analysis of Variance Table

\section{Response: MACALCAL}

\begin{tabular}{|l|l|l|l|l|l|}
\hline & Df & Sum Sq & Mean Sq & F value & $\operatorname{Pr}(>\mathrm{F})$ \\
\hline Year & 9 & 8544.5 & 949.38 & 7767.381 & $<2.2 \mathrm{e}-16 * * *$ \\
\hline TP & 2 & 23.0 & 11.49 & 93.976 & $<2.2 \mathrm{e}-16 * * *$ \\
\hline Year:TP & 17 & 26.3 & 1.55 & 12.665 & $<2.2 \mathrm{e}-16 * * *$ \\
\hline Residuals & 888 & 108.5 & 0.12 & & \\
\hline
\end{tabular}

Signif. codes: 0 ‘***’ 0.001 '**’ $0.01^{\text {‘*’ }} 0.05$ ‘’ 0.1 ‘ 1 


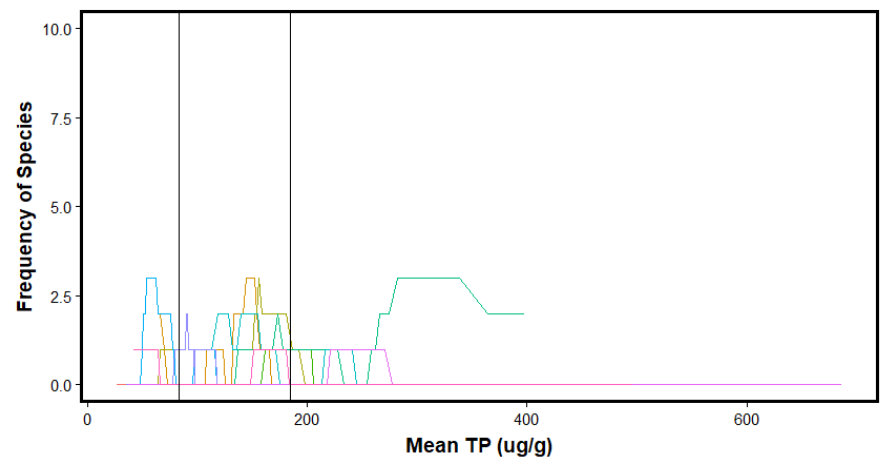

Years $-2007-2008-2010-2011-2013-2013-2015$

Figure C33. Plot of species frequency in network along a mean Total Phosphorus gradient $(\mu \mathrm{g} / \mathrm{g})$ for taxon Mastogloia lanceolata. Vertical lines indicate thresholds at 83 and $195 \mu \mathrm{g} / \mathrm{g}$. Two-way ANOVA with replication follows immediately.

Analysis of Variance Table

\section{Response: MALANLAN}

\begin{tabular}{|l|l|l|l|l|l|}
\hline & Df & Sum Sq & Mean Sq & F value & $\operatorname{Pr}(>\mathrm{F})$ \\
\hline Year & 9 & 42.486 & 4.7207 & 16.605 & $<2.2 \mathrm{e}-16 * * *$ \\
\hline TP & 2 & 5.991 & 2.9954 & 10.537 & $3.003 \mathrm{e}-05 * * *$ \\
\hline Year:TP & 17 & 93.960 & 5.5270 & 19.442 & $<2.2 \mathrm{e}-16 * * *$ \\
\hline Residuals & 888 & 252.445 & 0.2843 & & \\
\hline
\end{tabular}

Signif. codes: 0 ‘***’ 0.001 '**’ 0.01 '*’ 0.05 '? 0.1 ' ' 1 


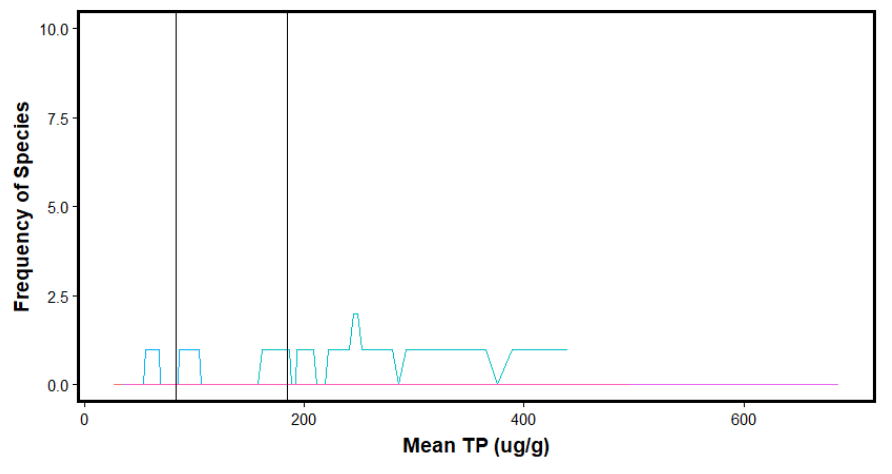

Years $-2007-2008-2010-2011-2013-2013-2015$

Figure C34. Plot of species frequency in network along a mean Total Phosphorus gradient $(\mu \mathrm{g} / \mathrm{g})$ for taxon Navicula densilineolata. Vertical lines indicate thresholds at 83 and $195 \mu \mathrm{g} / \mathrm{g}$. Two-way ANOVA with replication follows immediately.

Analysis of Variance Table

Response: NADENDEN

\begin{tabular}{|l|l|l|l|l|l|}
\hline & Df & Sum Sq & Mean Sq & F value & $\operatorname{Pr}(>\mathrm{F})$ \\
\hline Year & 9 & 37.908 & 4.2120 & 125.4085 & $<2.2 \mathrm{e}-16 * * *$ \\
\hline TP & 2 & 0.164 & 0.0820 & 2.4415 & 0.08762 \\
\hline Year:TP & 17 & 3.291 & 0.1936 & 5.7644 & $1.272 \mathrm{e}-12 * * *$ \\
\hline Residuals & 888 & 29.825 & 0.0336 & & \\
\hline
\end{tabular}

Signif. codes: 0 “***’ 0.001 '**’ 0.01 '*’ 0.05 '? 0.1 ', 1 


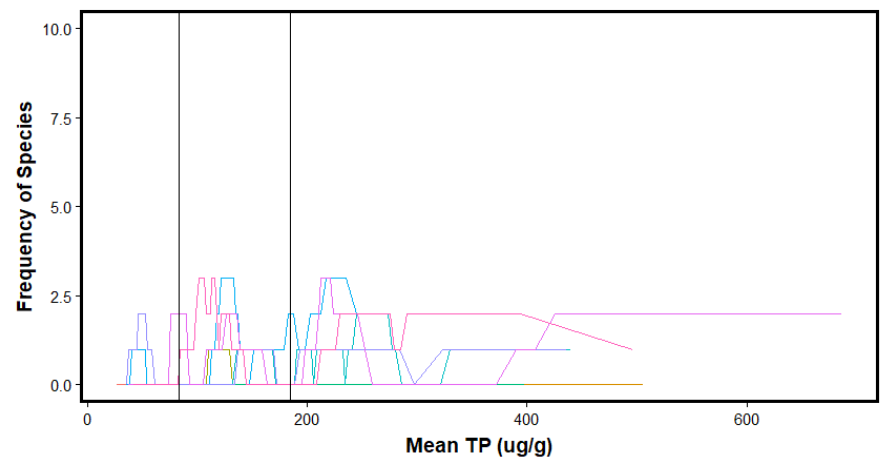

Years $-2007-2008-2010-2011-2013-2013-2015$

Figure C35. Plot of species frequency in network along a mean Total Phosphorus gradient $(\mu \mathrm{g} / \mathrm{g})$ for taxon Navicula radiosafallax. Vertical lines indicate thresholds at 83 and $195 \mu \mathrm{g} / \mathrm{g}$. Two-way ANOVA with replication follows immediately.

Analysis of Variance Table

\section{Response: NARAFRAF}

\begin{tabular}{|l|l|l|l|l|l|}
\hline & Df & Sum Sq & Mean Sq & F value & $\operatorname{Pr}(>\mathrm{F})$ \\
\hline Year & 9 & 152.715 & 16.9684 & 56.928 & $<2.2 \mathrm{e}-16 * * *$ \\
\hline TP & 2 & 21.813 & 10.9066 & 36.592 & $5.364 \mathrm{e}-16 * * *$ \\
\hline Year:TP & 17 & 59.691 & 3.5112 & 11.780 & $<2.2 \mathrm{e}-16 * * *$ \\
\hline Residuals & 888 & 264.682 & 0.2981 & & \\
\hline
\end{tabular}

Signif. codes: 0 “***’ 0.001 '**’ 0.01 '*’ 0.05 '? 0.1 ', 1 


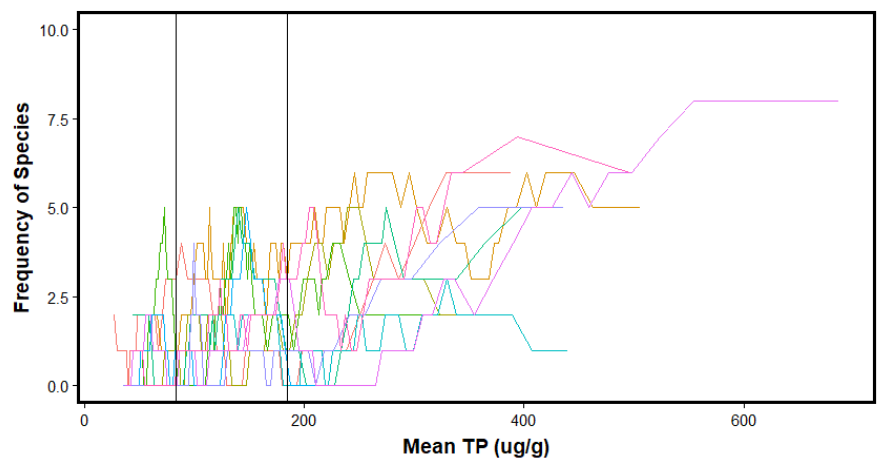

Years $-2007-2008-2010-2011-2013-2015-2016$

Figure C36. Plot of species frequency in network along a mean Total Phosphorus gradient $(\mu \mathrm{g} / \mathrm{g})$ for taxon Nitzschia amphibia. Vertical lines indicate thresholds at 83 and $195 \mu \mathrm{g} / \mathrm{g}$. Two-way ANOVA with replication follows immediately.

Analysis of Variance Table

\section{Response: NIAMPAMP}

\begin{tabular}{|l|l|l|l|l|l|}
\hline & Df & Sum Sq & Mean Sq & F value & $\operatorname{Pr}(>\mathrm{F})$ \\
\hline Year & 9 & 598.46 & 66.495 & 45.7820 & $<2.2 \mathrm{e}-16 * * *$ \\
\hline TP & 2 & 327.28 & 163.642 & 112.6677 & $<2.2 \mathrm{e}-16 * * *$ \\
\hline Year:TP & 17 & 222.88 & 13.110 & 9.0266 & $<2.2 \mathrm{e}-16 * * *$ \\
\hline Residuals & 888 & 1289.76 & 1.452 & & \\
\hline
\end{tabular}

$---$

Signif. codes: 0 ‘***’ 0.001 '**’ 0.01 '*’ 0.05 '? 0.1 ' , 1 


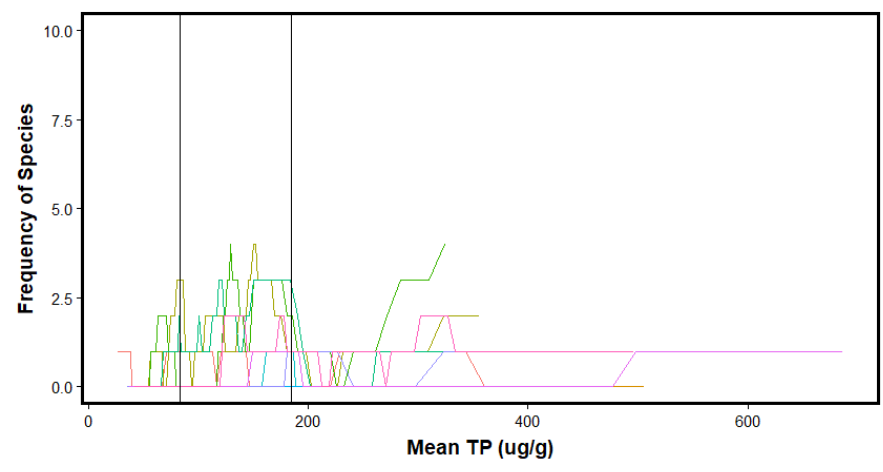

Years $-2007-2008-2010-2011-2013-2014-2015$

Figure C37. Plot of species frequency in network along a mean Total Phosphorus gradient ( $\mu \mathrm{g} / \mathrm{g})$ for taxon Nitzschia cf. semirobusta. Vertical lines indicate thresholds at 83 and $195 \mu \mathrm{g} / \mathrm{g}$. Two-way ANOVA with replication follows immediately.

Analysis of Variance Table

\section{Response: NICFSEMI}

\begin{tabular}{|l|l|l|l|l|l|}
\hline & Df & Sum Sq & Mean Sq & F value & $\operatorname{Pr}(>\mathrm{F})$ \\
\hline Year & 9 & 245.23 & 27.2483 & 75.7340 & $<2.2 \mathrm{e}-16^{* * *}$ \\
\hline TP & 2 & 29.08 & 14.5419 & 40.4179 & $<2.2 \mathrm{e}-16 * * *$ \\
\hline Year:TP & 17 & 58.29 & 3.4286 & 9.5296 & $<2.2 \mathrm{e}-16 * * *$ \\
\hline Residuals & 888 & 319.49 & 0.3598 & & \\
\hline
\end{tabular}

Signif. codes: 0 ‘***’ 0.001 '**’ 0.01 '*’ 0.05 '? 0.1 ' ' 1 


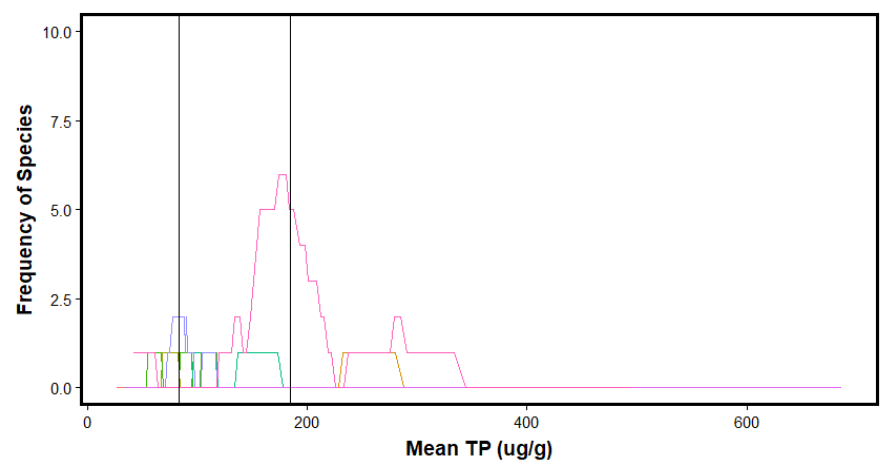

Years $-2007-2009-2011-2013-2015$

Figure C38. Plot of species frequency in network along a mean Total Phosphorus gradient $(\mu \mathrm{g} / \mathrm{g})$ for taxon Nitzschia ftsp16. Vertical lines indicate thresholds at 83 and $195 \mu \mathrm{g} / \mathrm{g}$. Two-way ANOVA with replication follows immediately.

Analysis of Variance Table

Response: NIFTSP16

\begin{tabular}{|l|l|l|l|l|l|}
\hline & Df & Sum Sq & Mean Sq & F value & $\operatorname{Pr}(>\mathrm{F})$ \\
\hline Year & 9 & 135.67 & 15.0741 & 42.1465 & $<2.2 \mathrm{e}-16 * * *$ \\
\hline TP & 2 & 4.57 & 2.2845 & 6.3872 & $0.001761 * *$ \\
\hline Year:TP & 17 & 42.39 & 2.4936 & 6.9720 & $4.681 \mathrm{e}-16 * * *$ \\
\hline Residuals & 888 & 317.60 & 0.3577 & & \\
\hline
\end{tabular}

Signif. codes: 0 “***’ 0.001 '**’ 0.01 '*’ 0.05 '? 0.1 ' ' 1 


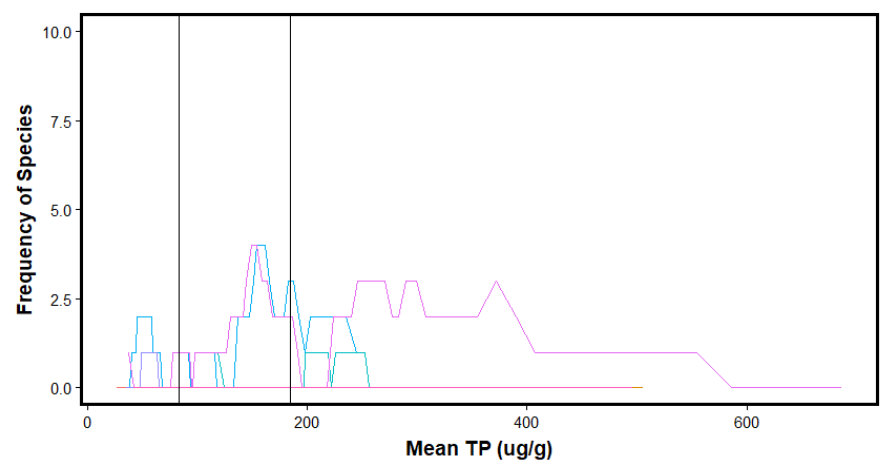

Years $-2007-2008-2010-2011-2013-2014-2015$

Figure C39. Plot of species frequency in network along a mean Total Phosphorus gradient $(\mu \mathrm{g} / \mathrm{g})$ for taxon Nitzschia intermedia. Vertical lines indicate thresholds at 83 and $195 \mu \mathrm{g} / \mathrm{g}$. Two-way ANOVA with replication follows immediately.

Analysis of Variance Table

Response: NIINTINT

\begin{tabular}{|l|l|l|l|l|l|}
\hline & Df & Sum Sq & Mean Sq & F value & $\operatorname{Pr}(>\mathrm{F})$ \\
\hline Year & 9 & 210.843 & 23.4270 & 113.695 & $<2.2 \mathrm{e}-16 * * *$ \\
\hline TP & 2 & 5.240 & 2.6199 & 12.715 & $3.595 \mathrm{e}-06 * * *$ \\
\hline Year:TP & 17 & 37.225 & 2.1897 & 10.627 & $<2.2 \mathrm{e}-16 * * *$ \\
\hline Residuals & 888 & 182.973 & 0.2061 & & \\
\hline
\end{tabular}

Signif. codes: 0 ‘***’ 0.001 '**’ 0.01 '*’ 0.05 '? 0.1 ' ' 1 


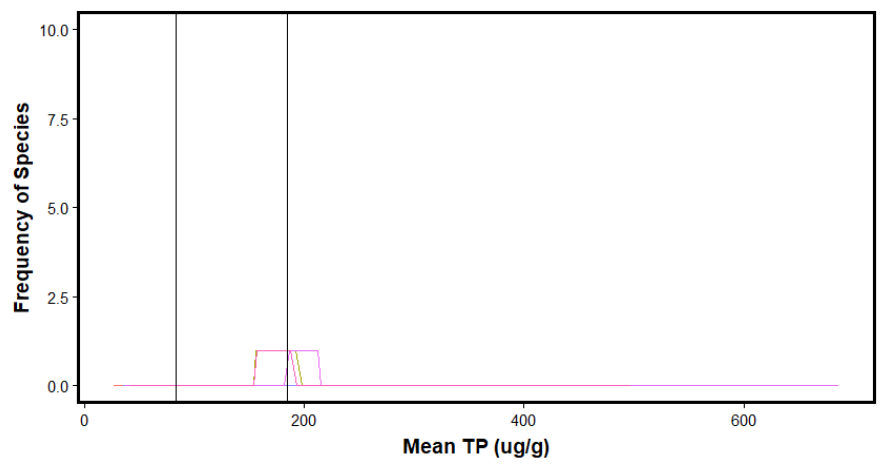

Years $-2007-2008-2010-2011-2013-2013-2015$

Figure C40. Plot of species frequency in network along a mean Total Phosphorus gradient $(\mu \mathrm{g} / \mathrm{g})$ for taxon Nitzschia microcephala. Vertical lines indicate thresholds at 83 and $195 \mu \mathrm{g} / \mathrm{g}$. Two-way ANOVA with replication follows immediately.

Analysis of Variance Table

Response: NIMICMIC

\begin{tabular}{|l|l|l|l|l|l|}
\hline & Df & Sum Sq & Mean Sq & F value & $\operatorname{Pr}(>\mathrm{F})$ \\
\hline Year & 9 & 2.0199 & 0.22444 & 8.2212 & $8.284 \mathrm{e}-12 * * *$ \\
\hline TP & 2 & 0.3658 & 0.18291 & 6.7000 & $0.001294 * *$ \\
\hline Year:TP & 17 & 2.3906 & 0.14062 & 5.1511 & $6.783 \mathrm{e}-11 * * *$ \\
\hline Residuals & 888 & 24.2422 & 0.02730 & & \\
\hline
\end{tabular}

Signif. codes: 0 “***’ 0.001 '**’ 0.01 '*’ 0.05 '? 0.1 ', 1 


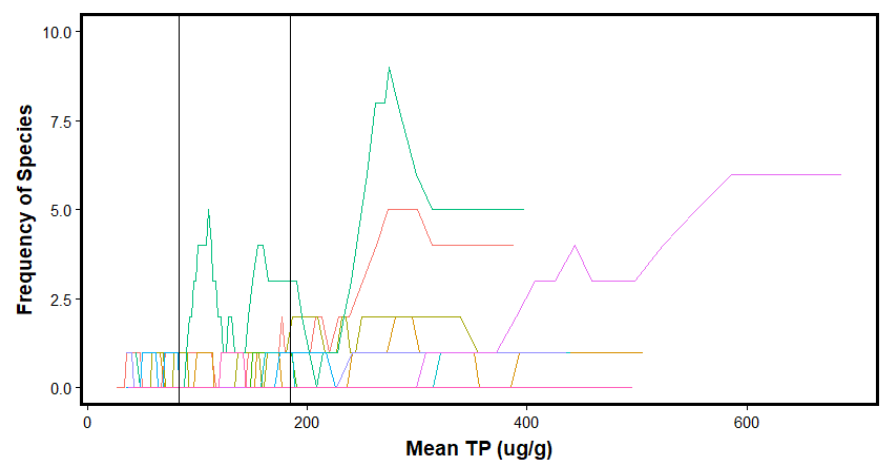

Years $-2007-2008-2010-2011-2013-2013-2015$

Figure C41. Plot of species frequency in network along a mean Total Phosphorus gradient ( $\mu \mathrm{g} / \mathrm{g})$ for taxon Nitzschia nana. Vertical lines indicate thresholds at 83 and $195 \mu \mathrm{g} / \mathrm{g}$. Two-way ANOVA with replication follows immediately.

Analysis of Variance Table

Response: NINANNAN

\begin{tabular}{|l|l|l|l|l|l|}
\hline & Df & Sum Sq & Mean Sq & F value & $\operatorname{Pr}(>\mathrm{F})$ \\
\hline Year & 9 & 398.11 & 44.235 & 74.121 & $<2.2 \mathrm{e}-16^{* * *}$ \\
\hline TP & 2 & 125.90 & 62.951 & 105.483 & $<2.2 \mathrm{e}-16 * * *$ \\
\hline Year:TP & 17 & 238.40 & 14.023 & 23.498 & $<2.2 \mathrm{e}-16 * * *$ \\
\hline Residuals & 888 & 529.95 & 0.597 & & \\
\hline
\end{tabular}

Signif. codes: 0 “***’ 0.001 '**, 0.01 '*’ 0.05 '? 0.1 ' ' 1 


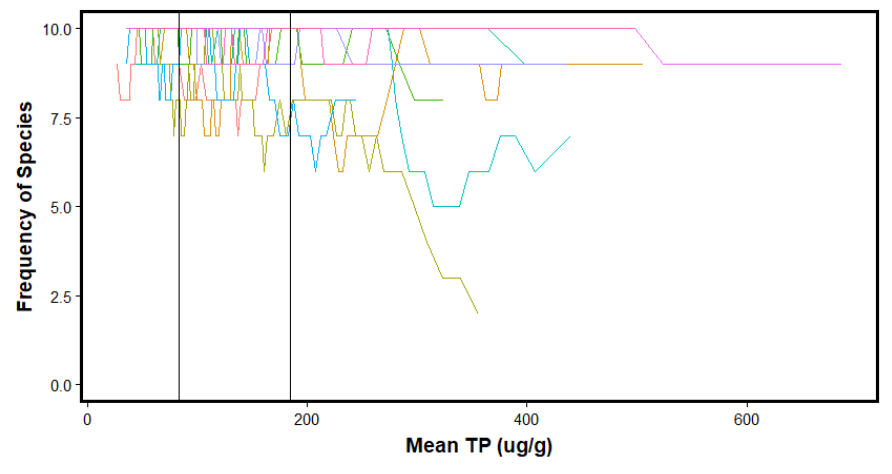

Years $-2007-2008-2010-2011-2013-2013-2015$

Figure C42. Plot of species frequency in network along a mean Total Phosphorus gradient $(\mu \mathrm{g} / \mathrm{g})$ for taxon Nitzschia palea var. debilis. Vertical lines indicate thresholds at 83 and $195 \mu \mathrm{g} / \mathrm{g}$. Two-way ANOVA with replication follows immediately.

Analysis of Variance Table

Response: NIPALDEB

\begin{tabular}{|l|l|l|l|l|l|}
\hline & Df & Sum Sq & Mean Sq & F value & $\operatorname{Pr}(>\mathrm{F})$ \\
\hline Year & 9 & 292.39 & 32.488 & 47.705 & $<2.2 \mathrm{e}-16 * * *$ \\
\hline TP & 2 & 45.38 & 22.690 & 33.318 & $1.116 \mathrm{e}-14 * * *$ \\
\hline Year:TP & 17 & 157.65 & 9.273 & 13.617 & $<2.2 \mathrm{e}-16 * * *$ \\
\hline Residuals & 888 & 604.75 & 0.681 & & \\
\hline
\end{tabular}

Signif. codes: 0 ‘***’ 0.001 '**’ 0.01 '*’ 0.05 '? 0.1 ' ' 1 


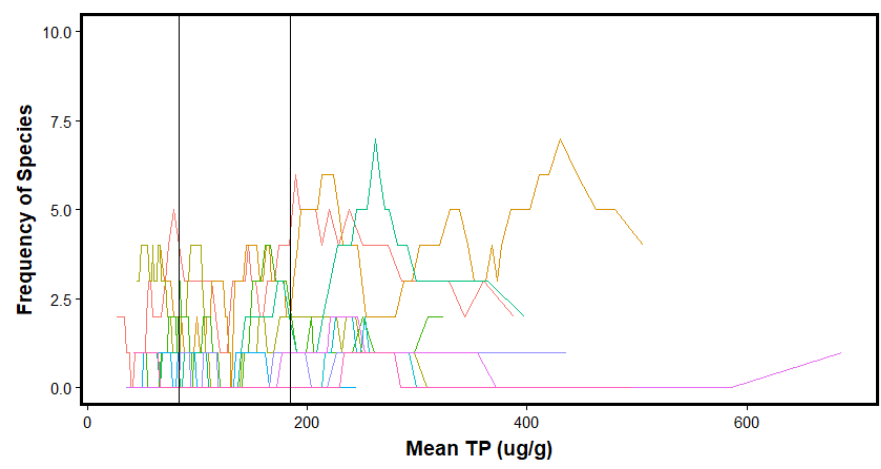

Years $-2007-2008-2010-2011-2013-2013-2015$

Figure C43. Plot of species frequency in network along a mean Total Phosphorus gradient $(\mu \mathrm{g} / \mathrm{g})$ for taxon Nitschia palea var. tenuirostris. Vertical lines indicate thresholds at 83 and $195 \mu \mathrm{g} / \mathrm{g}$. Two-way ANOVA with replication follows immediately.

Analysis of Variance Table

Response: NIPALTEN

\begin{tabular}{|l|l|l|l|l|l|}
\hline & Df & Sum Sq & Mean Sq & F value & $\operatorname{Pr}(>\mathrm{F})$ \\
\hline Year & 9 & 1003.99 & 111.555 & 154.560 & $<2.2 \mathrm{e}-16 * * *$ \\
\hline TP & 2 & 111.06 & 55.528 & 76.935 & $<2.2 \mathrm{e}-16 * * *$ \\
\hline Year:TP & 17 & 226.64 & 13.332 & 18.471 & $<2.2 \mathrm{e}-16 * * *$ \\
\hline Residuals & 888 & 640.92 & 0.722 & & \\
\hline
\end{tabular}

$---$

Signif. codes: 0 ‘***’ 0.001 '**’ 0.01 '*’ 0.05 '? 0.1 ' ' 1 


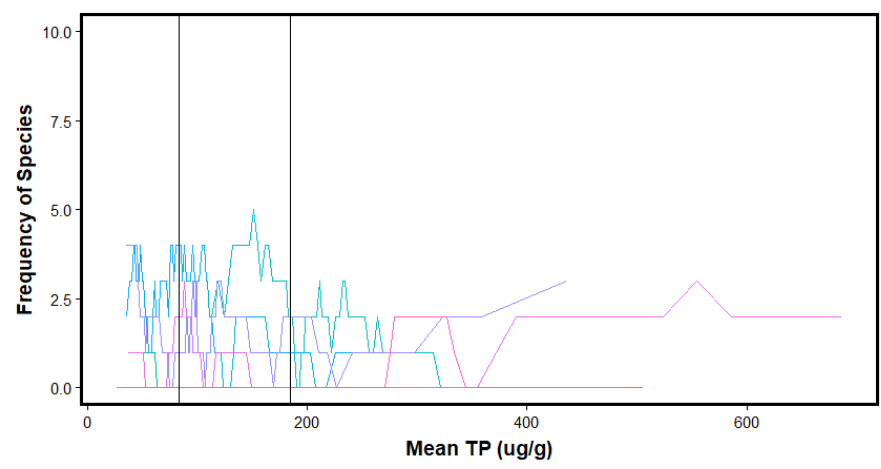

Years $-2007-2008-2010-2011-2013-2014-2015$

Figure C44. Plot of species frequency in network along a mean Total Phosphorus gradient $(\mu \mathrm{g} / \mathrm{g})$ for taxon Pseudostaurosira brevistriata. Vertical lines indicate thresholds at 83 and $195 \mu \mathrm{g} / \mathrm{g}$. Two-way ANOVA with replication follows immediately.

Analysis of Variance Table

\section{Response: PEBREBRE}

\begin{tabular}{|l|l|l|l|l|l|}
\hline & Df & Sum Sq & Mean Sq & F value & $\operatorname{Pr}(>\mathrm{F})$ \\
\hline Year & 9 & 622.38 & 69.154 & 193.533 & $<2.2 \mathrm{e}-16 * * *$ \\
\hline TP & 2 & 13.19 & 6.594 & 18.455 & $1.403 \mathrm{e}-08 * * *$ \\
\hline Year:TP & 17 & 102.09 & 6.005 & 16.806 & $<2.2 \mathrm{e}-16 * * *$ \\
\hline Residuals & 888 & 317.30 & 0.357 & & \\
\hline
\end{tabular}

Signif. codes: 0 ‘***’ 0.001 '**’ 0.01 '*’ 0.05 '? 0.1 ' ' 1 


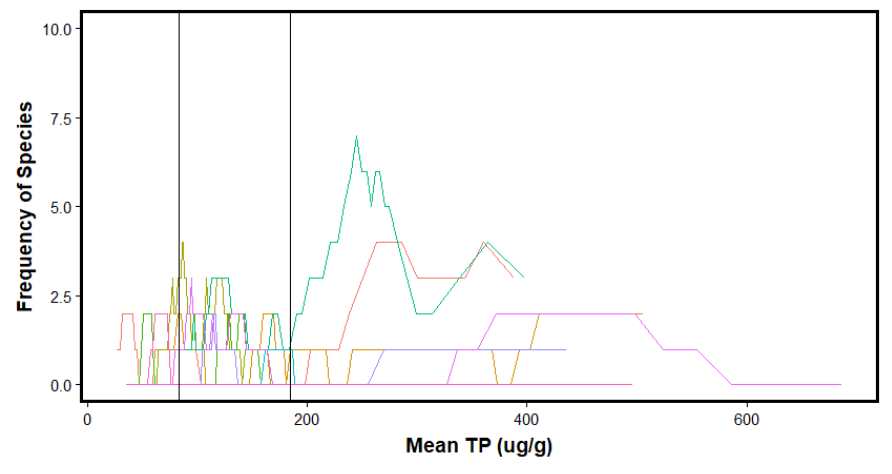

Years $-2007-2008-2010-2011-2013-2013-2015$

Figure C45. Plot of species frequency in network along a mean Total Phosphorus gradient ( $\mu \mathrm{g} / \mathrm{g})$ for taxon Pinnularia microstauron. Vertical lines indicate thresholds at 83 and $195 \mu \mathrm{g} / \mathrm{g}$. Two-way ANOVA with replication follows immediately.

Analysis of Variance Table

Response: PIMICMIC

\begin{tabular}{|l|l|l|l|l|l|}
\hline & Df & Sum Sq & Mean Sq & F value & $\operatorname{Pr}(>\mathrm{F})$ \\
\hline Year & 9 & 275.81 & 30.6460 & 67.531 & $<2.2 \mathrm{e}-16 * * *$ \\
\hline TP & 2 & 10.37 & 5.1864 & 11.428 & $1.257 \mathrm{e}-05 * * *$ \\
\hline Year:TP & 17 & 306.35 & 18.0207 & 39.710 & $<2.2 \mathrm{e}-16 * * *$ \\
\hline Residuals & 888 & 402.98 & 0.4538 & & \\
\hline
\end{tabular}

---

Signif. codes: 0 ‘***’ 0.001 '**’ 0.01 '*’ 0.05 '? 0.1 ' ' 1

Analysis of Variance Table 


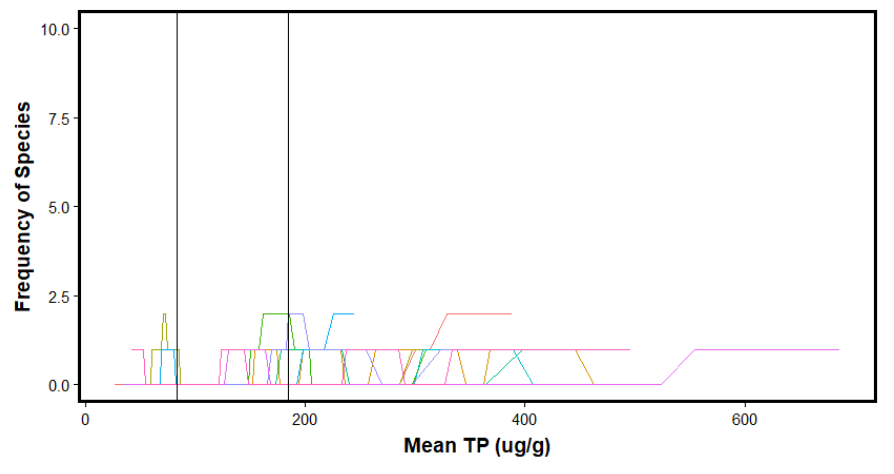

Years $-2007-2008-2010-2011-2013-2013-2015$

Figure C46. Plot of species frequency in network along a mean Total Phosphorus gradient $(\mu \mathrm{g} / \mathrm{g})$ for taxon Rhopalodia gibba. Vertical lines indicate thresholds at 83 and $195 \mu \mathrm{g} / \mathrm{g}$. Two-way ANOVA with replication follows immediately.

Analysis of Variance Table

Response: RHGIBGIB

\begin{tabular}{|l|l|l|l|l|l|}
\hline & Df & Sum Sq & Mean Sq & F value & $\operatorname{Pr}(>\mathrm{F})$ \\
\hline Year & 9 & 5.995 & 0.6661 & 4.065 & $3.977 \mathrm{e}-05 * * *$ \\
\hline TP & 2 & 16.020 & 8.0100 & 48.884 & $<2.2 \mathrm{e}-16 * * *$ \\
\hline Year:TP & 17 & 28.540 & 1.6788 & 10.246 & $<2.2 \mathrm{e}-16 * * *$ \\
\hline Residuals & 888 & 145.506 & 0.1639 & & \\
\hline
\end{tabular}

Signif. codes: 0 ‘***’ 0.001 '**’ 0.01 '*’ 0.05 '? 0.1 ' ' 1 


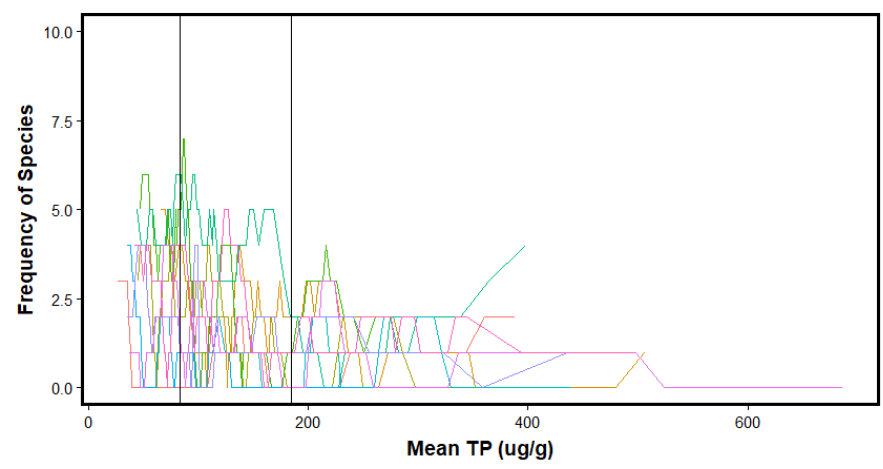

Years $-2007-2008-2010-2011-2013-2014-2015$

Figure C47. Plot of species frequency in network along a mean Total Phosphorus gradient $(\mu \mathrm{g} / \mathrm{g})$ for taxon Sellaphora laevissima. Vertical lines indicate thresholds at 83 and $195 \mu \mathrm{g} / \mathrm{g}$. Two-way ANOVA with replication follows immediately.

Analysis of Variance Table

Response: SELAELAE

\begin{tabular}{|l|l|l|l|l|l|}
\hline & Df & Sum Sq & Mean Sq & F value & $\operatorname{Pr}(>\mathrm{F})$ \\
\hline Year & 9 & 662.28 & 73.587 & 65.0805 & $<2.2 \mathrm{e}-16^{* * *}$ \\
\hline TP & 2 & 287.82 & 143.909 & 127.2743 & $<2.2 \mathrm{e}-16 * * *$ \\
\hline Year:TP & 17 & 188.83 & 11.107 & 9.8235 & $<2.2 \mathrm{e}-16 * * *$ \\
\hline Residuals & 888 & 1004.06 & 1.131 & & \\
\hline
\end{tabular}

Signif. codes: 0 ‘***’ 0.001 '**’ 0.01 '*’ 0.05 '? 0.1 ' ' 1 


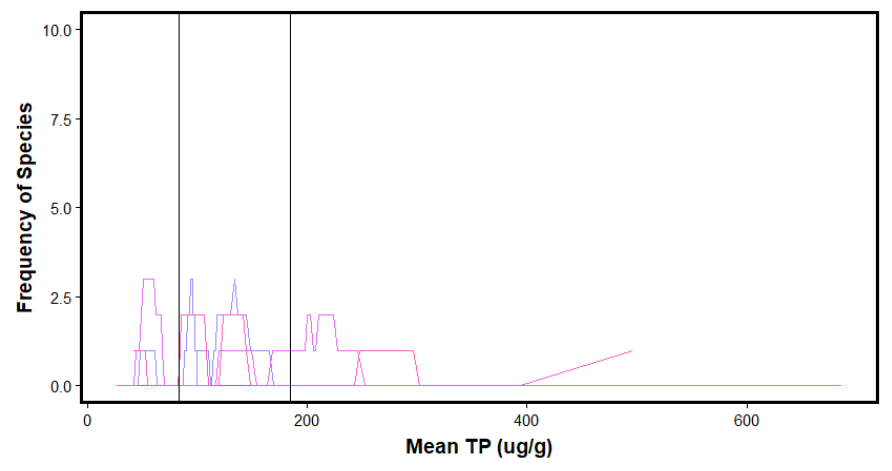

Years $-2007-2008-2010-2011-2013-2013-2015$

Figure C48. Plot of species frequency in network along a mean Total Phosphorus gradient $(\mu \mathrm{g} / \mathrm{g})$ for taxon Sellaphora seminulum. Vertical lines indicate thresholds at 83 and $195 \mu \mathrm{g} / \mathrm{g}$. Two-way ANOVA with replication follows immediately.

Analysis of Variance Table

\section{Response: SESEMSEM}

\begin{tabular}{|l|l|l|l|l|l|}
\hline & Df & Sum Sq & Mean Sq & F value & $\operatorname{Pr}(>\mathrm{F})$ \\
\hline Year & 9 & 96.300 & 10.7000 & 55.982 & $<2.2 \mathrm{e}-16 * * *$ \\
\hline TP & 2 & 4.781 & 2.3905 & 12.507 & $4.399 \mathrm{e}-06 * * *$ \\
\hline Year:TP & 17 & 40.366 & 2.3745 & 12.423 & $<2.2 \mathrm{e}-16 * * *$ \\
\hline Residuals & 888 & 169.725 & 0.1911 & & \\
\hline
\end{tabular}

Signif. codes: 0 ‘***’ 0.001 '**’ 0.01 '*’ 0.05 '? 0.1 ' ' 1 


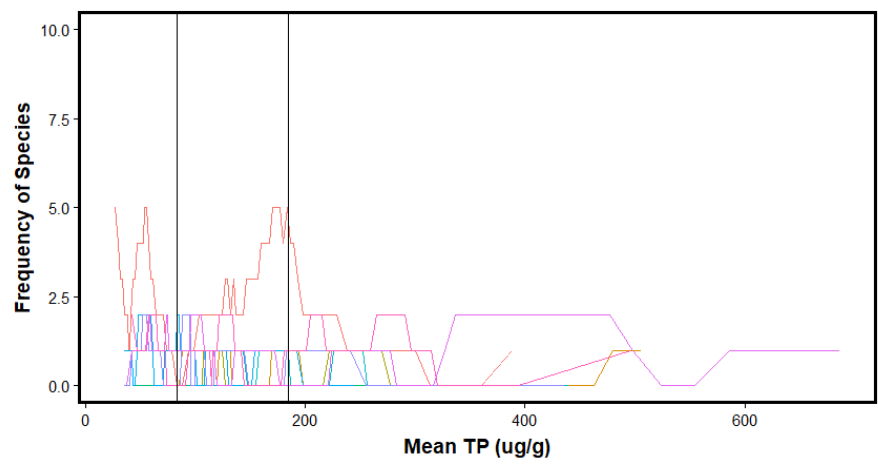

Years $-2007-2008-2010-2011-2013-2014-2015$

Figure C49. Plot of species frequency in network along a mean Total Phosphorus gradient $(\mu \mathrm{g} / \mathrm{g})$ for taxon Sellaphora stroemii. Vertical lines indicate thresholds at 83 and $195 \mu \mathrm{g} / \mathrm{g}$. Two-way ANOVA with replication follows immediately.

Analysis of Variance Table

Response: SESTRSTR

\begin{tabular}{|l|l|l|l|l|l|}
\hline & Df & Sum Sq & Mean Sq & F value & $\operatorname{Pr}(>\mathrm{F})$ \\
\hline Year & 9 & 381.00 & 42.333 & 111.6033 & $<2.2 \mathrm{e}-16 * * *$ \\
\hline TP & 2 & 9.55 & 4.774 & 12.5854 & $4.076 \mathrm{e}-06 * * *$ \\
\hline Year:TP & 17 & 39.87 & 2.345 & 6.1825 & $8.297 \mathrm{e}-14 * * *$ \\
\hline Residuals & 888 & 336.83 & 0.379 & & \\
\hline
\end{tabular}

Signif. codes: 0 ‘***’ 0.001 '**’ 0.01 '*’ 0.05 '? 0.1 ' ' 1 


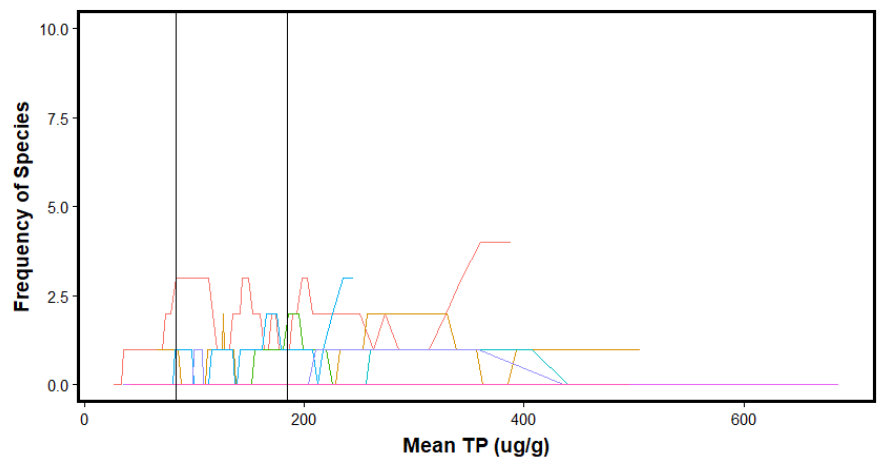

Years $-2007-2008-2010-2011-2013-2013-2015$

Figure C50. Plot of species frequency in network along a mean Total Phosphorus gradient $(\mu \mathrm{g} / \mathrm{g})$ for taxon Synedra filiformis var. exilis. Vertical lines indicate thresholds at 83 and $195 \mu \mathrm{g} / \mathrm{g}$. Two-way ANOVA with replication follows immediately.

Analysis of Variance Table

Response: SYFILEXI

\begin{tabular}{|l|l|l|l|l|l|}
\hline & Df & Sum Sq & Mean Sq & F value & $\operatorname{Pr}(>\mathrm{F})$ \\
\hline Year & 9 & 194.024 & 21.5582 & 129.742 & $<2.2 \mathrm{e}-16^{* * *}$ \\
\hline TP & 2 & 20.022 & 10.0109 & 60.248 & $<2.2 \mathrm{e}-16 * * *$ \\
\hline Year:TP & 17 & 34.943 & 2.0555 & 12.370 & $<2.2 \mathrm{e}-16 * * *$ \\
\hline Residuals & 888 & 147.552 & 0.1662 & & \\
\hline
\end{tabular}

Signif. codes: 0 “***’ 0.001 '**, 0.01 '*’ 0.05 '? 0.1 ' ' 1 


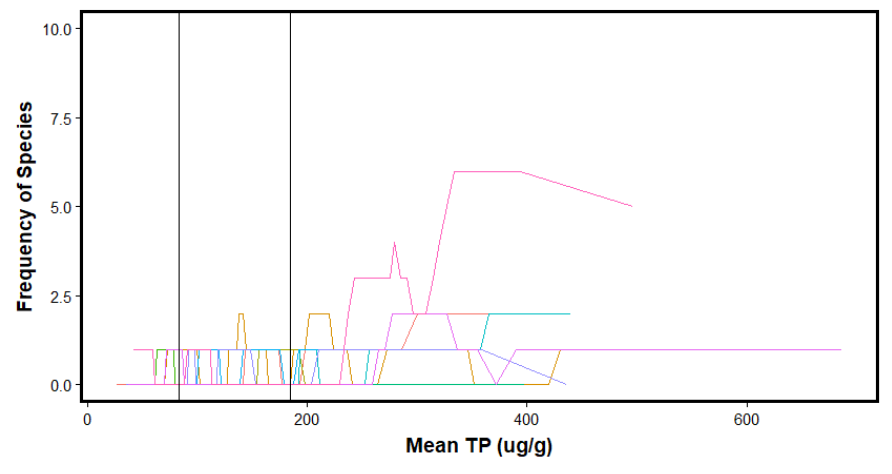

Years $-2007-2008-2010-2011-2013-2013-2015$

Figure C51. Plot of species frequency in network along a mean Total Phosphorus gradient $(\mu \mathrm{g} / \mathrm{g})$ for taxon Ulnaria delicatissima. Vertical lines indicate thresholds at 83 and $195 \mu \mathrm{g} / \mathrm{g}$. Two-way ANOVA with replication follows immediately.

Analysis of Variance Table

Response: ULDELDEL

\begin{tabular}{|l|l|l|l|l|l|}
\hline & Df & Sum Sq & Mean Sq & F value & $\operatorname{Pr}(>\mathrm{F})$ \\
\hline Year & 9 & 65.579 & 7.2865 & 22.108 & $<2.2 \mathrm{e}-16^{* * *}$ \\
\hline TP & 2 & 55.189 & 27.5944 & 83.725 & $<2.2 \mathrm{e}-16 * * *$ \\
\hline Year:TP & 17 & 78.256 & 4.6033 & 13.967 & $<2.2 \mathrm{e}-16 * * *$ \\
\hline Residuals & 888 & 292.668 & 0.3296 & & \\
\hline
\end{tabular}

Signif. codes: 0 “***’ 0.001 '**’ 0.01 '*’ 0.05 '? 0.1 ', 1 